


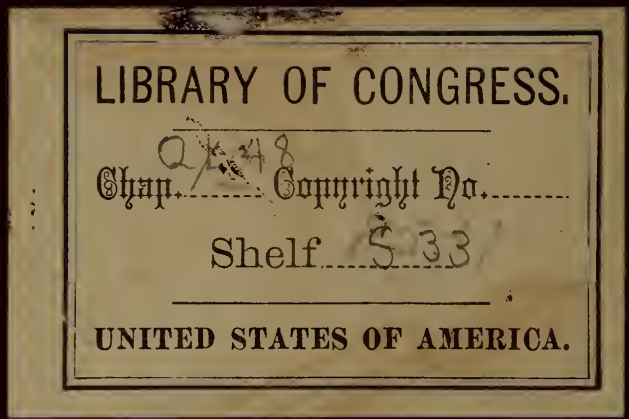


$+2$ 





\title{
PRINCIPLES OF ZOÖLOGY.
}

$-\mathrm{A}-$

\section{GUIDE FOR BEGINNERS,}

\author{
$\mathrm{BY}$

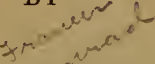 \\ RICHARD C. SCHIEDT,
}

Professor of Natural Sciences in Franklin and Marshall College, Lancaster, $\mathrm{Pa}$.

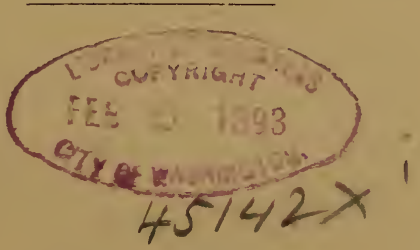

LANCASTER, PA.:

EXAMINER PRINTING HOUSE.

I892. 
COPYRIGHT BY RICHARD C. SCHIEDT,

IANCASTER, PA.

QL48

.533 


\section{PREFACE.}

This little book is intended for college students, to whom but little time is allotted for the study of the natural sciences. It is to be a companion to the general laboratory work outlined in the elementary text-books on practical zoölogy. Its contents are based upon the larger text-books of Professors Arnold Lang, Berthold Hatschek and Korschelt and Heider, which present the latest results of morphological research not yet published in the English language. We adopted Arnold Lang's classification, because it is the most complete of the latest systems. The embryological element preponderates on account of its importance for modern thought in general. Every college graduate ought to be acquainted with the fundamental principles of a science which has revolutionized the philosophic systems of the past, and given rise to a more rational treatment of the various disciplines of a college curriculum.

Special thanks are due to Dr. John A. Ryder, Professor of Comparative Embryology, at the University of Pennsylvania, for valuable assistance rendered in the critical reading of the proof.

R. C. S.

Lancaster, Pa., November, 1892. 



\section{ERRATA.}

Page I 7, line I: species instead (species).

Page 30, line 22: omit "always and."

Page 30, line 24: essential part of the egg instead eggcell.

Page 89: heading ought to be Cnidaria.

Page r Io, line 8: Archiannelida instead Archiamelida.

Pages II9-I43: heading on both sides ought to be Vermes instead Chætognatha.

Page $12 \mathrm{I}$, line $\mathrm{I} 3$ : median line this instead medium live the.

Page 226, line 3, from below: Opisthobranchiata instead Ophistobranchiata.

A number of minor oversights are here omitted. 



\section{CONTENTS.}

PAGE.

Introduction ................... . . 5

Protozoa ................... . . I9

Monera .................... . I9

Sarcodina . . . . . . . . . . . . . I9

Flagellata. . . . . . . . . . . . . . 2 I

Gregarinida . . . . . . . . . . . . . 2 I

Infusoria.................. . 22

Suctoria .................. . 22

Catallacta . . . . . . . . . . . . . . 22

Metazoa, General remarks on . . . . . . . . . . 29

Structure of egg. . . . . . . . . . . . . . 30

Formation of egg . . . . . . . . . . . 3I

Cell division . . . . . . . . . . . . . . . 32

Segmentation ................ . . 34

Histology .................. 44

Modes of Reproduction . . . . . . . . . . . . . 66

Theories of Heredity . . . . . . . . . . . 7 I

Cœlenterata . . . . . . . . . . . . . . 76

Gastræada .. . . . . . . . . . . . . 76

Porifera .. . . . . . . . . . . . . 77

Cnidaria ................... . . 81

Ctenophora ................. 87

Plathelminthes................. . . 95

Turbellaria................ . . 95

Trematoda................ . . 96

Cestoda . . . . . . . . . . . . . . . 97

Vermes ..................... . . 104

Nemertini . . . . . . . . . . . . . 104

Nemathelmia ............... . . 105

Annulata ................... . 108

Prosopygii .................. . . II 2

Rotatoria ................ . II6

Chætognatha .................. . 116 
Arthropoda ..................... . . I67

Branchiata ................... . . I67

Crustacea ................ . . I67

Trilobita ................... . . I77

Gigantostraca . . . . . . . . . . . . . I78

Hemiaspidæ ................. . I78

Xiphosura ................... . . . . . . . . . . . . .

Pantopoda ................. . . I79

Tracheata ............... . . . . . . . . . . . . . .

Protracheata ................ . . I80

Antennata .................. . . 180

Arachnoidea ................. . . I89

Mollusca..................... . . . 22I

Amphineura ................. . . . 222

Gasteropoda ... . . . . . . . . . . . 223

Scaphopoda . . . . . . . . . . . . . . 230

Lamellibranchia . . . . . . . . . . . . 230

Cephalopoda . . . . . . . . . . . . . 234

Echinodermata................ . . . 256

Crinoidea . . . . . . . . . . . . . 256

Echinoidea ................ . . . 258

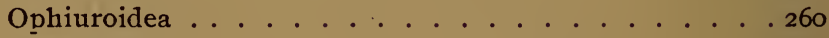

Asteroidea .................. . . 26I

Holothuroidea ............... . . 263

Enteropneusta ................. . . . 275

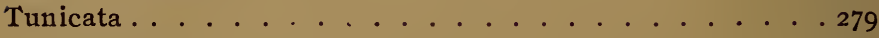

Ascidiæ................. . . . 279

Thaliacea . . . . . . . . . . . . . 282

Vertebrata ................... . . . . 290

Cephalochorda............... . . . . 290

Acrania . . . . . . . . . . . . . . . 290

Craniata ................... . . . 29I

Agnatha ................... . . . . . . . .

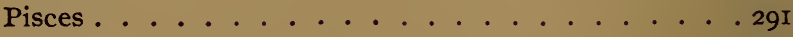

Batrachia . . . . . . . . . . . . . 294

Monocondylia . . . . . . . . . . . . . 295

Mammalia .................. . . 297 


\section{INTRODUCTION.}

§. Plant and Animal. The aim of Zoology is the study of animal life. The question arises: What is an animal? The answer to this question is simple, when dealing only with the more highly developed organisms; it is extremely difficult, when dealing with the lowest forms of life, because the starting point of all organic life and formation, is the cell. The simplest organisms, the lowest animals and plants, are cells. Every larger animal is at the beginning of its individual existence a cell, and every higher organism is composed of cells, which are the result of the reproduction of one cell.*

The cell is the organic individual of the first order.

Excepting the lowest organisms, a cell generally multiplies and forms communities or states, which thus compose individuals of a higher order. Every higher organism, every bird, every fish, etc., is such a community of cells. In it the closely connected cells divide the common labor, one assuming the discharge of one function, another of another function, according to its particular ability.

Every cell consists of two essential constituents: (I) the protoplasm; (2) the nucleus. The latter may be considered as a special differentiation of protoplasm. Chemically considered, protoplasm is a complex albuminous carbon compound, not yet sufficiently analyzed, whose constituents constantly change during life, although only

*See Arnold Lang's "Die Zelle," 
within infinitesimally small limits. It is in a condition of sluggish motion and capable of swelling. The nucleus is a chemical and physical differentiation within the protoplasm. It is an essential part of the cell, in whose reproduction it plays an important part. Recent observations prove that the removal of the nucleus destroys the cell: The addition of a nucleus to a non-nuclear plasma portion produces characteristic phenomena, which otherwise would not have arisen.

There are minute lumps of protoplasm, representing the simplest organisms, in which as yet no nucleus has been observed. Should the non-nuclear character of these beings be proved, they would have to be ranked below the cell, namely among the cytodes. Haeckel has classified these simplest organisms as Monera.

A frequent, however not essential, part of the cell, is the cell skin or membrane, an excreted product of protoplasm, which serves as an external protection or support. Such a membrane can likewise originate through the hardening and metamorphosis of the peripheral layers of protoplasm.

A single cell (one-celled organism, ovum) is originally fitted for all those activities and functions, which are comprehended under the idea of life.

The life of a cell manifests itself in the simplest, most undifferentiated case:

I. In motion. Protoplasm is contractile. Its finest visible parts can exchange position. The cell is capable of changing its form and position in space.

2. In irritability. The cell reacts through such motions upon effects from the outside.

3. In metabolism. Through the activity of life the substance within the cell is used up, decomposed. The 
useless material is excreted (excretion). Through the reception of food new substances are added to the cell. These are digestible, when they can be assimilated by the chemical action of the cell, and changed into constituent parts of protoplasm (assimilation). If this is chemically impossible, these substances are indigestible, and are again eliminated from the body.

4. In growth. Through nourishment more protoplasmic parts may be formed than there are originally present. As a consequence, the cell increases in mass and size; it grows.

5. In reproduction. It may be supposed that the size of the cell is individully limited. If it grows beyond the individual measure, it divides into two cells. Reproduction by division. Each of the two parts has the same physical and chemical properties as the mother-cell. Simplest case of heredity. Through growth the daughtercell reaches the size of the mother-cell.

Now, since the cell is the starting point, both for animals and plants, it is easily seen, that there can be no distinct line of demarkation between the two kingdoms in their lower forms. Haeckel has, therefore, established an intermediate kingdom, consisting of the lowest organisms, the kingdom of Protists. However, there exists not even between these protists on the one hand and the animals and plants on the other, a sharp line of distinction. Chiefly in the method of taking in food, some of the protists approach more nearly the plants, others more nearly the animals. The latter are called Protozoa in contra-distinction from all the other animals, the Metazoa.

§II. It is very important to note that the foregoing results are of comparatively modern date. To understand and appreciate them well, it is necessary to know 
something of the historic development of Biological Science. Aristotle (4th century B. C.) is generally acknowledged as the founder of this science. He wrote treatises on the "Reproduction of Animals," "Parts of Animals, and History of Animals." The last named is only incompletely preserved. These titles alone indicate the philosophic comprehensiveness of the work, touching even then upon the embryology, morphology and physiology of animal life. He divided the animals into eight groups:

Animals with blood, Vertebrates-

I. Viviparous animals, (four-footed, including whale); 2. Birds; 3. Oviparous, four-footed animals; 4. Fishes. Animals without blood, Invertebrates-

5. Soft animals (Cephalopoda). 6. Soft animals with shells; 7. Insects; 8. Shelled animals, (Echini, snails and mussels).

The two main divisions rest, of course, on an erroneous idea since all animals have blood, the invertebrates only lacking red corpuscles. This system reigned supreme till the end of the Middle Ages. Even the modern systems since Ray and Linnæus are based upon it. It was, however, not until the renaissance of the sciences in the I6th century that the works of Aristotle again came to the front, and the desire for experimental independent observation was aroused. The splendid discoveries of Harvey, Kepler and Newton in physics, of Swammerdam, Malpighi, Leeuwenhœk, Hamm, and others in natural history, offered a preparation for the labors of Carl Linnaus (I707-1778), whose system forms the starting point for all modern systems. Ray, before him, had introduced the conception of species and the consideration of anatomical characters as the 
basis of classification; however he lacked methodical arrangement. The importance to the development of science of Linnæus' work depended entirely on his acute sifting and exact division of the then existing facts, and on the introduction of a new method of more certain diagnosis, nomenclature and arrangement. He looked upon the whole animal world as a single ascending series of forms, and advanced the doctrine of the uni-serial arrangement of the animal kingdom, erecting for groups of different value, a number of categories based on the ideas of species, genus, order, class. Every animal received two names taken from the Latin language, the generic name, which was placed first, and the specific name Thus, by the introduction of binary nomenclature, he created a systematic framework, not only for the facts known then, but for all the discoveries of the future. His great work, "Systema Naturæ," is nothing more than an exhaustive catalogue of all the then known specimens of animals, plants and minerals, with a statement of their most remarkable characteristics. Thus his systems of classification, both in botany and zoölogy, are artificial, resting merely on isolated features of internal and external structure. His division of animals into six classes is founded on the structure of the heart, the condition of the blood, manner of reproduction and respiration.

Cuvier's conception of the different structures of animals opened up a new epoch of zoölogical systems. George Cuvier, born at Mömpelgard, in I769, Professor of Comparative Anatomy at the Jardin des Plantes in Paris, published his investigation, especially in his "Lecons d'Anatomie Comparée" (I805). In his new and essentially changed classification, he made the first $\mathrm{B}^{*}$ 
serious attempt to build up a natural system, based entirely upon the idea of the correlation of parts. Recognizing the reciprocal dependence of the individual organs, he found, by comparing the organizations of many different animals, that the important organs are the most constant, and that the less important vary most in their forms and development, and are not even universally present. Thus he became convinced that there were in the animal kingdom four main types, "general plans of structure, on which the respective animals appear to be modelled." These four groups were the Vertebrata, Mollusca, Articulata and Radiata. We may therefore call Cuvier's doctrine, the doctrine of the parallel series in opposition to the School of Natural Philosophy in France, led by Geoffrey St. Hilaire, who maintained the unity of the plan of animal structure. Cuvier's principles met with the more undivided assent since they seemed to be affirmed by Carl Ernst von Baer's embryological work. In our times, however, Cuvier's view has experienced an essential modification in favor of the natural philosophers. Comparative anatomy found ascending grades of organization in the vertebrates of the present; paleontology discovered a corresponding gradation in the vertebrates of the past; and embryology revealed the same serial gradation in developmental stages. The discovery of this most remarkable parallelism between the three series, the anatomical, the paleontological and the embryological, is one of the most brilliant in the whole history of biology, and one which is to be placed to the credit of Louis Agassiz. The absolute independence and isolation of each group must be given up. But just as the transitional forms between animals and plants cannot abolish the distinction between these 


Linnæus' System. Cuvier's System.

1. Cl. Mammalia.

1. Cycle: Tritebrata.

Ord Primates Feræ, Glires, Pecora, Bellua, Cete

2. Cl. Aves.

Ord. A c i i itres, 2

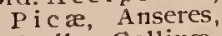
Pica, Galline, Passeres.

3. Cl. Amphibia. Ord. Reptiles, Ser pentes,

4. Cl. Pisces lares, 'Thoracici, Abdomiuales.

5. Cl. Inserla.

Ord. Col coptera, Hemiptera, Lepidoptera, Neuroptera, Hyule 11 o ptera, Diptera Aptera.

Cl. Maumalia.

2. Cl. Ares.

3. Cl Reptilia

4. Cl. Pisces.

Cycle: Mollusca.

I. Cl. Cephalopoda

2. Cl. Pteropoda.

3. C1. Gasteropoda

4. Cl. Acephala.

5. Cl. Brachiopoda.

6. Cl. Cirthopoda.

3. Cycle: Ariculata.

I. Cl. Annelides.

2. Cl. Crustacea.

I. Sect.

traca.

2. Sect. Eutoniostraca.

3. Cl. Arachnides.

4. Cl. Insecta.

Ord. Myriapoda, Thysanura.etc.

6. Cl. Vermes. Thysanura.etc Ord. Intestina, Mol-4. Cycle: Radiala. lusca, Iestacea, I. Cl. EchinodermaI,ithophyta, Zoophyta.
2. Cl. Intestiua.

Ord. Nematoidea

Parenchymata)

3. $\mathrm{Cl}$. Acalephre.

(Ord. Simplices

Hydrostatice).

4. Cl. Polypi.

5. Cl. Infusoria

(Ord. Porifera Homogenea.)

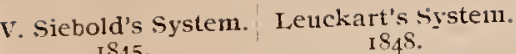

Claus' Systenl. I 887
Hacckel-Hatschek. 1888.
Protozoa.

Cl. Infusoria.

2. Cl. Rhizopoda

II. Zoophyla.

3. Cl. Polypi (Anthozoa, Bryozoa

4. Cl. Acalepha. ata.

II. Vermes.

6. Cl. Helminthes.

7. C1. Turbellarii.

8. Cl. Rotatorii

9. Cl. Annulati.

IV. Mollusca.

io. Cl. Acephala.

('Tunicata, Brach-

iopoda aud io podibra chiata.)

I $\mathrm{Cl}$. Cepli a lophora.

I Cephalopoda

I. Althiopoda.

3. Cl. Crustacea.

14. Cl. Arachnida.

I5. Cl. Insecta.

VI. Vertebrata.
A. Protozoa (to be I. Piotozoa. separated from the other animals.)

Coelenterata.

1. Cl. Polypi.

2. Cl. Acalephre.

(Spongia

Echinodermala.

- Echindi.. Enter pueusta. 3. Cl. Pelinatozoa. 4. Vermes (PlatyhelOrd.Cystidea, miuthes, NemathelCrinoidea.)

minthes, Annelides 4. Cl. Actinozoa. Rotatoria.)

(Ord. Echinida, 5. Arthropoda (CrustAsterida.) acea, Arachnoidea,

5. Cl. Scytodermata Ouychophora, My(Ord.Holothuria riopoda,Hexapoda) and Sipnnculi-6. Mollusca.

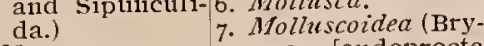

7. Molluscoidea (Bry-
ozoa leudoprocta

6. Cl. Anenterati. and ectoprocta] (Ord Cestodes, Brachiopoda. A cautocephali.) 8. Tunicata.

7. Cl. Apodes. 8. unicata.

(Ord. Nemertini,

Turbellarii, Tre matodes, Hirtıinei.l

8. Cl. Ciliati. (Ord. Bry ozoa, Rodiferi.)

9. Cl. Annelides.

(Ord. Nematodes I, u $\mathbf{m}$ br i c i ni Branchiati.

IV. Arthropoda.

10. Cl. Crustacea.

I I. C1. Insecta.

V. Mollusca.

12. Cl. Tunicata (!)

I3. Cl. Acephala.

14. Cl. Gasteropoda

15. Cl. Cephalopoda

VI. Vertebrata.
A. Protozoa.

. Mletazoa.

Protaxonia (=colen. terata.)

I. Type, Spongiaria. I. Clad.Spougiaria.

II. Type, Cridaria.

2. Clad. Cnidaria.

I. Cl. Hydrozoa.

2. Cl. Scyphozoa.

App. Planuloidea.

III. Type, Clenophora. 3. Clad. Cteuophora

Heteraxonia (=Bilateria.)

IV. 'Type, Zygoneura.

Subtype: Autoscolecida.

4. Clad. Scolecida. 1. C1. Platodes

2. C1. Rotifera.

3. Cl. Endoprocta 4. Cl. Nem atodes 5. Cl. Ac a utho cephali.

App. Nemertiui.

2. Subtype: A poscoleci da. (Metanephrido zoa.)

5. Clad. Articulata. I. Cl. Annelida.

A pp. Sipunculoidea.

App. Chaetoguathi.

2.Cl.Onychophora 3. C1. Arthropoda

6. Clad. Tentaculata (=Molluscoidea.) $1 \mathrm{Cl}$. Phoronida.

2. C1. Bryozo (ectoprocta.)

3. Cl.Brachiopoda

7. Clad. Mollusca.

I. Subclad. Amphineura.

2. Subclad. Conchifera.

V. 'Type, $4 m b u l a c l a$ lia.

8. Clad. Echinoderinata.

9. Clad. Enteropneusta.

VI. 'Type, Chordonii. ro. Clad. Tunicata

I I. Clad.I.eptocardi i I Clad. Vertebrata. I Subclad. Cyclostomata.

2. Subclad. Girathostomata. 


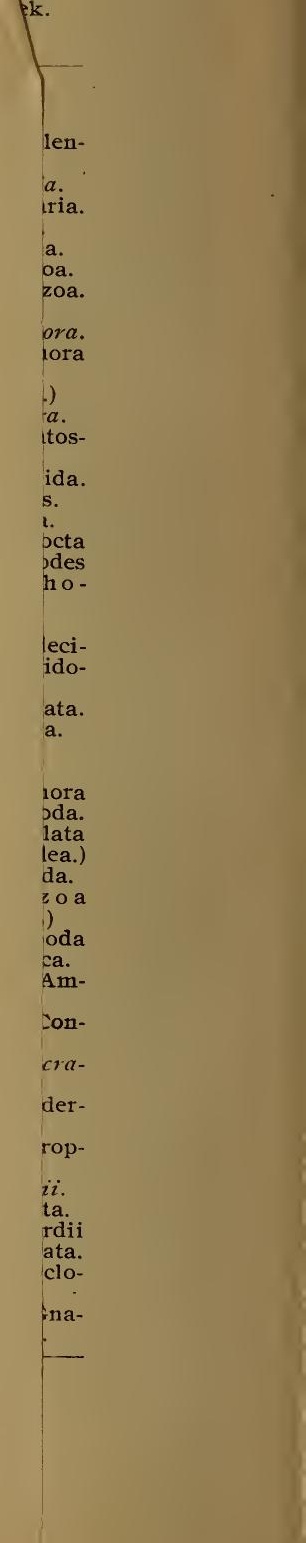


two most important conceptions of the organic kingdom, so the existence of such transitional forms does not in any way affect the value of the idea of groups and types as the chief divisions of the animal system; but only renders it probable that the different groups have developed from a similar or common standing-point. It was left for Charles Darwin to show that the coincidence pointed out by Agassiz between the geological succession, the embryonic development and the zoölogical gradation held also in the geographical distribution of animals in the past and the present, and to found the interpretation of the fact now universally accepted. Descent was seen to be "the hidden bond of connection," and embryonic development came to be regarded as the epitomized history of ancestral development. "In two or more groups of animals, however much they may differ from each other in structure and habits in their adult condition, if they pass through closely similar embryonic steps, we may feel assured that they are all descended from one parent form." So we find that the higher groups are genetically to be derived from the worms, etc. Thus embryology came to have a higher value in classification than anatomy, and to take the place assigned to it by $\mathrm{C}$. von Baer more than a half century ago as "the true torch-bearer in the investigation of organic bodies."

Under such circumstance we find it convenient to place the different methods of classification side by side, in order to show the difference of the various principles which govern the methods up to the present time. (See the table.) It will be noticed that the last ones represent no longer parallel series, but a genealogical tree. In the book itself the latest classification of Invertebrates as 
given in Prof. Arnold Lang's "Lehrbuch der Vergleichenden Anatomie" has been adopted, whilst the classification of Vertebrates is taken from Prof. E. D. Cope's. "Synopsis of Vertebrate Palæontology."

The above table shows that Hatschek's classification is decidedly distinct from that of his predecessors. It is chiefly based upon modern embryological investigation, first begun (1870) by Kowalevsky. Haeckel was the first one to point out their great importance for classification. The systematic significance of his gastræa theory culminates in the following important fact: "The whole animal kingdom is divided into two great series separated by the gastrula; on the one side, the Protozoa (Urthier); on the other, in sharp contrast, the six higher animal branches, which may be termed the Metazoa or Blastozoa." The morphological significance of this apparently simple division may be comprehended in this statement. All higher animal branches are derived from the gastræa, a form common to all, which possesses a monaxial body, whose cavity opens at one pole through the primitive mouth, and whose body wall consists of two cell strata the exoderm and the endoderm. Although Haeckel's attempts to define the relations of the different types more closely, partly failed, a whole series of similar investigation followed, some of which will be of lasting value, e. g., the hypothesis, that the vertebrates are derived from the annelids, established by Semper.

\section{Principles of Morphology.*}

Biology, or the science of the organisms, comprises two sub-groups: Physiology, dealing with the functions

*See Hatschek's “Principien der Morphologie.". 
of life, and Morphology, dealing with the structure (internal and external) of organisms.

Physiology either treats of the special relation of the form of an organism to its physiological functions, when it is called physiological anatomy, or it sets forth general principles which govern the formation of typical organization, e. g., the functions of the bilateral or the radial structure of living beings, when it is spoken of as physiological Morphology or it may have reference to the laws of mechanics, nourishment or growth in the development of structures; as such it is termed physiological embryology.

Morphology, in the special sense of the word, or Genealogical Morphology is the name of that science which exclusively treats of the structure of organisms, and their relation to common ancestral forms.

Morphology may therefore be subdivided into comparative anatomy and comparative embryology (comp. ontogeny).

PRINCIPLES OF COIIPARATIVE ANATOIY.

The theory of descent firmly established the principles of comparative anatomy. The distinction between homology and analogy is here of special importance.

The term homology is used to designate identity of descent of certain organisms, i. e., in the sense of homophyly. Analogy is used to designate the similarity of structure in organisms of different descent, but of the same physiological function, e. g., homologues are the anterior extremities of all vertebrates, although they may physiologically vary as fins, feet or wings. Homologous are the swimming bladder of the fish and the lung of higher vertebrates. Analogous, however, are the feet of 
a vertebra, and those of an insect, or the wings of an insect and those of a bird; so the wings of bats are only homologous as anterior extremities; in their structure as wings they are analogous. Further, the lungs of a vertebrate and the tracheæ of an insect are analogous ; so also the highly developed eye of a cephalopodon and that of a vertebrate.

Homodynamous organs are organs of the same kind repeated in the same animal, e. g., the anterior and posterior or extremities of a vertebrate animal; homotypical are the organs repeated on either side of a bilateral or in the rays of a radial animal.

PRINCIPLES OF COMPARATIVE EMBRYOLOGY (BIOGENETIC $\mathrm{I}, \mathrm{AW}$ ).

Distinctions between homology and analogy are here of even greater importance than in comparative anatomy. It must be maintained of all plants and animals save the simplest unicellular organisms, that each one is represented during life not merely by one fixed structural condition, but by a series of such conditions, although one is always predominant for a longer period, generally that in which reproduction takes place. This is especially true of the multicellular organisms, where the unicellular ovum gradually differentiates into a complex variety of tissues and organs. Comparative embryology, therefore, treats not of comparisons of single structual conditions, but of series of such conditions. Already at the beginning of the Igth century we find it stated that the higher animals pass in their development, through stages which in their structure correspond to certain lower animal forms. C. E. v. Baer elaborated that idea further, and the theory of descent created new interest in it, until 
Fritz Müller, in I864, found what we may call the formula for comparative embryology which is valid to this very day.

"The historical manuscript (of the development of the ancestors) preserved in the history of development (of individuals) gradually fades with the steadily straightening course of development from the egg to the complete animal; and it is frequently forged through the struggle for existence, which the larvæ of independent modes of living have to undergo. The primitive history of the species (phylogenesis) will be so much more complete in the history of its development (ontogenesis), the larger the series of immature condition is through which it has to pass pari passu, and so much more faithful the less the mode of living among the different stages differs, and the less it is found, that the peculiarities of the different immature conditions are retrogressions from later epochs or are independently required. (Für Darwin, Leipzig. I864, p. 77. 78.)" Thus the embryonic character depends upon its ability of further development. Ernst Haeckel deserves the credit of having been the first one who introduced this theory methodically, e. g., in his socalled "Gastræa Theory," where he endeavors to explain phylogenetically the first stages of development, and to prove the relation of all metazoan organisms to a common ancestral form, the gastræa.

The theory of the parallelism of individual development with the historical development of the species was termed by Haeckel "Fundamental Law of Biogenesis," and expressed in the sentence: Ontogeny is a short repetition of Phylogeny. He divides the phenomena into palingenetic which repeat the phenomena of a once developed ancestral form, and into cenogenetic phenomena 
which arose by adaption to the embryonic or larval life.

Hatschek, a pupil of Haeckel, has further developed and modified these theories, reaching the conclusion that the phylogenetic changes occur in most cases through an addition of new stages to the end of the ontogenetic series of forms. He explained this by maintaining that since, in his opinion* only those new characteristics are transmitted, which originate through the variations of the reproductive cells, "overreaching varieties" must be accepted, which consist in a continuation of the ontogenetic series of forms. Therefore cenogenetic characters of ontogeny are just as important for the investigation of animal relationship as the palingentic characters. Care must be taken, however, that we do not go too far in these theories, makiug every larval or embryonic form, which is characteristic for a whole group of animals, the representative of a similar phylogenetic stage.

\section{Meaning of the System. Categories of the System.}

It is easy to see that the system is based upon a similarity of organisms which is different in degree. Knowing that descent is the cause of similarity, we can easily understand that the actual basis of the system must be the genealogy of the crganisms. The system is an expression of our views, referring to the relationship of organisms, a relationship based upon actual descent. The arrangement of the system, according to larger divisions and smaller subdivisions, corresponds to the branches and twigs, of the genealogical tree. The usual divisions or catagories are: kingdom (regnum), subkingdom (subregnum), also called cycle, type or phylum; class (classis); order (ordo); family (familia);

* Weissmann. 
genus, (species). The binary nomenclature of Linnæus requires only the two last divisions in naming an organism.

\section{MEANING OF SPECIES.}

The similarity of organisms increases the deeper we descend in the categories. The idea of species, however, is not only based upon similarity of form, but much more upon the relation of sexual intercommunion which takes place within the species.

I. Similarity of the individuals of one species. Identity of cycles of forms, not of single forms, is the ontogenetic requirement. Complications arise through alternations of generation when the individual is repeated not in the cycle of one, but of two or more generations; further, through polymorphism, when one male is complemented by two or three females; or one female by two male forms; also through functional polymorphism, which is, e. g., found among the bees, where males, females and workers exist, or among the termites and ants, where there are more families of workers.

Temporary changes conditioned by environment are, according to Nägeli: Variations, and as such nonessential. Transmitted differences in the same individual are varieties. If they occur only in one individual, they are individual varieties; if in a large number of individual, race varieties, or simply race or subspecies. The races are considered as the beginnings of the formation of new species. It is however, a matter of course that under certain conditions variations and varieties may belong to one and the same species.

2. Perfect fertility within the species. Cuvier first emphasized the necessity of perfect fertility as an important 
criterion of the species in the crossing of their individuals. Perfect fertility is continuous through many generations among the individuals of the same species. The individuals of different species of the same genus are only imperfectly reproductive, i. e., their fertility decreases and disappears within the next generation or generations. An exception is the crossing of hare and rabbit.

The species is therefore not simply a sum of individuals, but rather a phy'siological unit formed by these individuals. 


\section{PROTOZOA.}

I CLASS: Monera. Simplest organisms. Small lumps of protoplasm of various, changeable form, in which nuclei have not yet been discovered. Locomotion and nourishment by means of either obtuse (amœboid) or pointed threadlike processes (pseudopodia). Reproduction by fission or budding. All monera live in water. Protamoba, Myxodiction, Protomyxa.

II CLASS: Sarcodina. Unicellular organisms with one or more nuclei. Locomotion and nourishment by means of changing, shorter or longer, threadlike, nonciliating processes (pseudopodia). Reproduction by fission or budding.

I. Subclass: Amobina. Sarcodina naked or enclosed in shells of changing form. Locomotion and nourishment effected through the flow of the body and the formation of changing processes of short, leaflike form. Contractile vacuoles mostly present. Amoba proteus, Arcella vulgaris, Difflugia pyriformis, Quadrula symmetrica, Hyalosphenia lata.

2. Subclass: Rhizopoda. Sarcodinà whose protoplasm secretes a shell of varying form; at first mono-axillar, chitinous, mostly calcareous. Nourishment and locomotion through pseudopodia, which often fuse, forming a network. Contractile vacuoles mostly absent.

A. Imperforata. Shells one or many-chambered, having one or two larger openings through which proto- 
plasm and pseudopodia protrude, not pierced by fine pores. Miliola, Lituola, Gromia oviformis.

B. Perforata. Shells one or two-chambered, perforated in order to protrude pseudopodia. Globigerina, Rotalia.

3. Subclass: Heliozoa. Sarcodina, naked or enclosed within silicious shell, with fine, somewhat stiff pseudopodia, protruding in all directions. Contractile vacuoles mostly present in varying numbers. Actinophrys sol., Actinospharium. Acanthocystis, Clathrulina.

4. Subclass: Radiolaria. Body separated by a capsular membrane; originally round or oval, into an external (extracapsulum) and an internal nuclear part (central capsule). The extracapsulum consists of non-nuclear protoplasm and a slimy envelope (calymma), whence their pseudopodia protrude in all directions. Skeletons of extraordinarily variable form, consisting of silica or a chitinous organic substance, are rarely absent. Wonderfully rich in differentiations of form. Without contractile vacuoles. Unicellular algae found with them. Family of Polycettaria forms colonies.

A. Porulosa. Central capsule spherical, without main opening, with innumerable fine pores.

I. Spumellaria. Nucleus central, dividing late. Skeleton silicious or absent, never penetrating the intracapsular protoplasm. Thalassicolla, Collozoum, Spharozoum, Thalassoplancta, Collosphaera Dictyastrum.

II. Acantharia. Nucleus extra centric, dividing early. Skeleton chitinous, radiating from the middle of the central capsul. Acanthometra, Phractaspis.

$B$. Osculosa. Central capsule oval, main opening at the basal pole of chief axis. Skeleton silicious, always extra capsular. Nucleus dividing late.

III. Nassellaria. Capsular mẹmbrane simple, a porous 
ring at the oral pole of the chief axis. Nassela, Cortina, Cornutella.

IV. Phaodaria. Capsular membrane double, at the oral pole of the chief axis the osculum, which is closed by a radially striped cover, with a central drawn out opening. Pigment bodies in the calymma. Aulosphara, Aulactinium, Cannopilus, Challengeria.

III CLASS : Flagellata (Mastigopora). Organisms of one cell or of colonies of one cell, rank very low, allied to certain fungi. Possess one or more long flagella or cilia. With contractile vacuoles. Reproduction by fission or budding, often after preceding copulation of the reproductive individuals.

I Order: Flagellata s. str. During active life provided with flagellæ exclusively. Monas, Euglena, Chilomonas, Eudorina, Pandorina, Stephanosphara, Volvox.

II Order: Choanoflagellata. Flagellum surrounded at basis by funnel-1ike collar. Phalansterium, Salpingœea, Protospongia.

III Order: Cystoflagellata. Protoplasm shows the netted structure of that of the plant cell. Noctiluca, Leptodiscus.

IV Order: Dinoflagellata (Cilioflagellata). Shelled forms. Outside of the freely protruding flagellum a second separate flagellum, moving in a special cross furrow of the body, formerly looked upon as a row of cilia. Peridinium, Ceratium.

IV CLASS: Gregarinida. Parasitic protozoa of slender form. Always only one nucleus. Without pseudopodia, without cilia, without contractile vacuoles, without special differentiation of protoplasm, with external cell membrane. Reproduction by spores after copulation or conjugation. 
I Order: Monocystidea. Body simple. Monocystis (in earthworm). Urospora.

II Order: Polycystidea. Body separated by a partition wall into protomerit and deutomerit. Nucleus in deutomerit. Actinocephalus, Stylorhynchus, Clepsidrina.

V CLASS: Infusoria (Ciliata). Unicellular, rarely colonized protozoa, with cilia or cilia-like continuations for locomotion and nutrition. Mostly with contractile vacuoles, mouth and anus. With nucleus of various forms and peculiar paranucleus (falsely nucleolus). Reproduction by fission, frequently by conjugation.

I Order: Holotricha. Cilia covering the whole body in rows. Paramacium, Trachelius.

II Order: Heterotricha. Cilia in the region of the mouth grouped so as to form an adoral zone of large bristle or hook-like cilia. Spirostomum, Stentor, Freia, Balantidium.

III Order. Hypotricha. Dorsal and ventral plane sharply divided. Chilodon, Euplotes, Stylonychia, Oxytricha, Urostyla.

IV Order: Peritricha. Body spherical or cylindrical, only partially ciliated. Cilia either in an adoral spiral or in a girdle. Vorticella, Carchesium, Epistylis, Trichodina, Strombidium, Tintinnus, Ophrydium

VI CLASS: Suctoria (Acineta). Body usually without cilia (only when young); with knobbed tentacle-like processes, which serve as sucking tubes, through which they suck the protoplasm of other infusoria. Reproduction by budding. Acineta, Podophrya, Dendrocometes.

VII CLAss: Catallacta. Only one genus and species; Magosphara planula. Free swimming in the sea. Coast of Norway. A spherical colony of pear-shaped cells, whose stems are united in the center, the external-sur- 
face covered with cilia. Reproduction: the colony separates into single cells. They sink to the bottom, become like amœba, form a capsule and within this a new colony through successive fission. Afterwards the colony separates from the capsule.

The protozoa are unicellular organisms or simple colonies of similar unicellular organisms. Frequently more than one nucleus appears. The morphological differentiation is developed to the highest degree in some protozoa, so that a complication of structure arises, which furnishes special provisions for every function of life, while the lowest protozoa accomplishes the same work with the simplest apparatus. Protoplasm flows around its food, assimilates, excretes, grows and divides in order to reproduce itself. Reproduction by fission.

I. Protoplasm. The protoplasm of many protozoa is homogeneous. In the majority, however, a differentiation into a more firm, hyaline ectosarc and a more fluid, granular endosarc is observed. Only in the Radiolaria both parts are separated by a membrane with communicating openings of various contrivances. From the ectosarc are developed: the pseudopodia, cilia, flagella, strcking tentacles, cuticula, skeletons, contractile vacuoles and the lasso-cells. In the endosarc are found: the nucleus, food vacuoles, excretion products, drops of fat or oil, gas bubbles and pigment granules. The endosarc sometimes exhibits slow circulation. The arrangement of the prutoplasm resembles, especially in the Cystoflagellata, that of the plants. Many flagellata contain chlorophyll or other similar pigments.

II. Locomotion. The Rhizopoda, Heliozoa, and Radiolaria, move and take food through pseudopodia. There are two kinds of such pseudopodia: myxopodia and axopodia. 
The former are found among Rhizopoda and Radiolaria and are very flexible, whilst the latter are more or less stiff and not adapted to the formation of nets.

Related to the pseudopodia are the flagella, vibrating processes of the extosarc, occurring among the Flagellata.

Undulating membranes have been observed among the Flagellata.

Cilia fine, vibrating, hair-like processes are characteristic for the Infusoria and the young of the Suctoria.

At the base of the mouth of Noctiluca a large, slowly vibrating, ribbon-like flagellum has been observed.

The Gregarinida have no organs of locomotion, the extosarc being differentiated into contractile and not contractile stripes.

The Vorticella possesses a spirally moving muscle stem.

'The myophrysks of the Acanthometridæ have the power of contraction.

The sucking tubes of the Suctoria are most closely related to the Suctoria.

III. Membranes, shells, skeleton formations. Many protozoa are naked. Others are covered by a chitinous membrane (e. g. Gromia). The infusoria are enveloped in a cuticula, which may harden into shells. The complicated shell of the Dinoflagellata consists of cellulose. Jelly-like envelopes also appear. The marine Rhizopoda carry lime shells (originally chitinous membranes). The Heliozoa secrete a silicious skeleton. The skeletons of the Radiolaria show wonderful complications; in some they are silicious and external, in others they are organic and central. The protomerit, deutomerit and epimerit of the Gregarinida, produced by partition walls, have already been mentioned. The cysts or capsules are formed for protection against atmospheric conditions. 
IV. Apparatus for nutrition. The organs of locomotion serve also for the apprehension of food. Only the Infusoria and certain Flagellata possess a mouth opening, mostly surrounded by cilia and only noticed when food is conveyed to it. The same protozoa possess also an anus.

V. Apparatus for excretion. It is doubtful whether the contractile vacuoles really serve as organs of excretion. Their number is varying. They are wanting altogether in the Rhizopoda, Radiolari, Gregarinida and Cystoflagellata. When there is only one it generally has a definite position. Before and during contraction they move to the surface, empty their contents and vanish. They arise again as small droplets. Perhaps they also serve purposes of respiration, changing the water.

VI. Trichocystes. Small bladders with lasso threads occur in the ectoplasm of a few infusoria and of one Flagellate.

VII. Stigmata or red eye spots are found singly in many colored Flagellata; their function is doubtful.

VIII. Nuclei are wanting in the monera. In the others there is either one or more than one present. They are situated in the endosarc, being either vesicular (differentiated) or homogeneous. Their form is very varying, especially among the Infusoria, where we find a nucleus and a paranucleus. The nucleus degenerates during or after copulation, the new nucleus forming out of the paranucleus. The division of the nucleus is either direct or indirect.

IX. Reproduction. A series of transitions from the simplest asexual to the sexual reproduction has been established. Reproduction by simple fission is known to 
exist among almost all the Protozoa, except among the Gregarinida. Budding in the simplest form differs from the preceding inasmuch as one part is smaller (bud) than the other (mother). That includes the possibility of numerous buds. Fission and budding occur together among Rhizopoda, Heliozoa, a few Gregarinida, in Noctiluca and the Suctoria. The processes of fission and budding are probably preceded by the conjugation (temporary combination) or by the copulation (permanent union) of two individuals. In a great many cases the buds or parts remain together and form colonies, an important factor which reminds us of the cell-colonies of Metazoa. Noctiluca presents a good example for budding. After the buds are produced each one separates as a swarmspore with flagellum and peculiar process. Very frequent is the reproduction by continued fission and spore formation. In the latter case the whole body is divided into a large number of nuclear parts called spores, which usually move about freely; sometimes they are amœboid, or provided with flagella as swarmspores. These two last named forms of reproduction occur among encysted individuals, frequently after conjugation or copulation, so among the Grezarinida and the Flagellata. The spores frequently reproduce by division, and these parts become adult animals.

Reproduction of colonies. Colonies are the result of incomplete division; they can reproduce themselves by division. Among the Radiolaria and the Flagellata swarmspores are formed. Among the colony forming Radiolaria the contents of the central capsule produce alternating spores : I. Isospores, corresponding to the usual spores of the other Radiolariæ. 2. Anisospores, which are again subdivided into Microspores and Macrospores. In 
the former, development is direct, in the latter after copulation. The microspores and macrospores are formed either in one and the same individual of a colony or in more than one. A probable alternation of generation. The processes of reproduction in the colony forming Flagellata are very interesting. In the simplest case every individual of a colony divides into a number of parts, which separate together as a daughter colony from the mother colony. In other cases the different parts of a daughter colony (gametæ) separate. Every two and two of different size copulate. The product (zygote) becomes after a while again a colony by division. In Eudarina and Volvox distinct sexual generations arise; in the former sexual generations follow asexual ones; they are either female (ovoid gametce) or male (spermoid gamete); in the latter a division of labor occurs, inasmuch as only certain individuals are reproductive, and both sexes are produced in one and the same individual. This is a genuine alternation of generations. The sexual reproduction corresponds to that of the Metazoa. The female gamete corresponds to the ovum, the male to the spermatozoon. The formation of a new Volvox colony by successive fission of the zygote corresponds to the cell division of the metazoa. Something similar has been observed among the colony forming Infusoria. 



\section{ME'TAZOA.}

From the protists or Protozoa are distinguished the higher animals or Metazoa. Their body consists of a large number of cells which form a community, morphologically complicated and physiologically perfected by a division of labor. Some of them are little above the Protozoan colonies. Such are, e. g., the Hydra. Their bodies consist of only a few different kinds of cells: of digestive, of neuro-muscular, of lasso and of reproductive cells (ova and spermatozoa). All these cells are indispensable to the existence of the body; if any one of them should be wanting the body would die. Thus the whole is physiologically an individual; but in contradistinction from the cell an individual of a second higher order, frequently called a person. Most animals remain in this stage of individuality. A medusa, a worm, a crab, a cat, are individuals of the second order. In some of them reproduction takes place by fission or budding without separation of the new individuals. Thus an individual of the third order or a cormus is formed. The individuals composing such a cormus may either remain alike, when they bear a similar relation to the cormus as the cell individuals of a Protozoan colony to this colony; or, another division of labor may take place and consequently also a different formation and function of the structure of the individual persons belonging to the cormus (polymorphism). Most corals belong to the former, the Siphonophora to the latter class of cormi. 
However complicated such a community of cells may be, it always (asexual reproduction excepted) originates in one single cell, namely, in the fertilized ovum, which itself is the result of the union of a female with a male reproductive cell. This process is called sexual reproduction. It presupposes on the part of one of the cells, at least, free motion and the power of resistance against external influences. These cells are besides very small, and therefore present in very large numbers and capable of easily entering the second cell. They are the male reproductive cells or spermatozoa. The other cell is to form the new organism, and must therefore possess a considerable amount of food material. They are the largest cells, generally called female reproductive organs or ova. Both are formed either in the same individual (hermaphroditism) or in two different individuals, male and female (gonochorism). The former is the exception, the latter the rule. It is probable that the sexes of all Metazoa were originally separate. There are special organs of copulation to assist foreign fertilization.

The structure of the ovum shows two distinct constituents. The essential part, which is always and often alone present, is the egg cell; of secondary importance are the external albuminous'masses and egg covers. The egg cell (also called "yolk") is morphologically a cell con sisting of nucleus, cell body and cell membrane. The nucleus, also called germinal vesicle, consists of a membrane, a fibrous network and one (or more) nucleolus (macu$1 æ$ germinativæ). The cell body consists of protoplasm in which yolk substances are imbedded. They constitute the reserve food material, being either of a liquid albuminous or fatty nature, or, as in most cases, solid albuminous yolk granules. Theșe are of varying shape and present in 
various quantities. The cell membrane is formed by the egg cell itself, and found in almost all ova, except where a chorion or follicular membrane is developed. It is called yolk membrane, and possesses a various consistency. Both, yolk membrane and chorion, are the primary membranes, whilst many ova show secondary membranes and food stuff, arisen from the accessory glands of the genital organs. In many Metazoa several eggs are enclosed by a secondary membrane.

The formation of the egg takes place in the ovaria. The young ovum has the structure of a simple undifferentiated cell; when ripening it separates, increases in size and forms primary membranes The germinal layer of the ovaria often resembles an incoherent plasma mass with numerous nuclei. Later, however, cell membranes form and the mass separates into distinct cells, which assume a spherical shape. Growth may be complete at this moment or continue. In young egg cells the nucleus is large and the protoplasm sparing. In the process of growth the latter increases more rapidly than the former; in some cases yolk substance separates from the cell; in others it enters the cell from neighboring follicular cells. Membranes are generally developed at the end of the growing period; the yolk membrane arises from the egg cell itself, the chorion from the follicle cells surrounding the egg cell. There are two modes of egg formation. Among the lower animals every epithelial cell of the ovirium becomes a solitary independent egg cell, often fastened by a stem to the germ layer; among the higher animals groups of cells arise, but only one in each group develops into a genuine egg cell, whilst the others furnish its food and its membrane (chorion). This is called follicular egg formation. 
Spermatoza are developed in the testes, which are equivalent to the ovaria; here, likewise, epithelial cells change into reproductive cells. Their general form resembles small ciliated cells, representing a head, consisting of nuclear substance and a small amount of protoplasm, and a movable tail. Animals, void of cilia, contain simple cone- amœboid- or star-shaped spermatozoa without a tail. The epithelial germ cells of the testes first change into so-called mother cells (spermatoblast, spermatogony), which divide, forming spermatocyta; these in turn change into separate spermatozoa. The spermatoblast is the equivalent of the ovum. They are much smaller and more numerous than the ova, but they contribute equally much to the fertilized egg. The female furnishes the substance, the male the energy of combination. Before passing to this stage of the process we have to consider cell division in general.

Cell division is always introduced by a division of the nucleus. "Omnis nucleus e nucleo." Direct cell division takes place only among monocellular organisms; the cell divides into two parts by a median constriction. Indirect cell division (caryokinetic or mitotic) implies a series of characteristic nuclear changes.

I. At the beginning of cell division two opposite centres of attraction (asters or archoplasmic spheres) arise on opposite sides of the nucleus; protoplasmic particles group themselves around them in a radiating manner (archoplasmic filaments). The chromatic (stainable) parts of the nucleus arrange themselves into a filamentous bundle along the periphery.

2. The nuclear membrane disappears, and the chromatic filamentous bundle divides into separate parts.

3. These parts, each shaped like a bow, arrange them- 
selves in an equatorial plane between the two archoplasmic spheres, their angular ends directed towards the nuclear centre and connected by achromatic fibriles with the archoplasmic centres.

4 At the same time the archoplasmic filaments press forward and flatten the poles of the nucleus, until they have reduced the chromatic contents of the nucleus into a flat "plate," thus forming two cone-shaped spindles, facing each other with their apices.

5. By gradually lengthening they continue to grow in the same manner, and push through between each other, thus dividing and carrying with them the chromatic bows or chromosomes, which split lengthwise and move one-half towards the one end of the nucleus the other towards the opposite end, thus forming two parallel plates (metakinesis).

6. The chromosomes again change into a filamentous bundle, around each of which a nuclear membrane is to be recognized. During this process there arises on the surface of the mother cell, between the two archoplasmic spheres, a segmentation which grows deeper and deeper until, after the formation of two new daughter nuclei, the cell is divided into two new cells.

The above facts are necessary in order to fully understand the union of two different cells and the subsequent fertilization. As soon as the ripe ovum has left the ovarium (sometimes before) certain changes occur which are necessary conditions of fertilization. The germinal vesicle changes into a nuclear spindle, which moves towards the surface of the animal pole of the ovum. Accompanied by radiating phenomena of the protoplasm, a part of this spindle is ejected in form of a little ball ("directive or polar body"). In most cases a $c^{*}$ 
second polar body is ejected. The rest of the spindle assumes its former structure and moves towards the interior. It is called the "egg nucleus" or "female pronucleus." The polar bodies perish. It has been actually proved that fertilization consists of a union of the nuclei of ovum and spermatozoon, and that only a single sperma. tozoon is received by the ovum.

We find even in the lowest Metazoa a certain arrangement of the cells after fertilization or segmentation has been going on for some time. They form in the simplest Colenterata two strata of an epithelial character which, in close adhesion, constitute the wall of the tubular body, open at one end. In accordance with the physiological functions of the different cells, the lasso cells or nettling organs and the neuro-muscular cells form the external stratum; whilst the nutritive cell make up the internal stratum, i. e., the one nearest the intestinal canal. The reproductive cells lie protected in the deeper layers of the external stratum. These two strata, which occur in all Metazoa, are called Ectoderm and Entoderm.

Thus cells or tissues of the same or of different kind combine to cell or tissue complexes. Such complexes are called organs when the cells or tissues, composing them, together join in the performance of one or several functions. A primitive organ is, e. g., the entoderm of a hydra, because all its cells perform the function of nutrition. The tentacles of the same are, however, more complicated organs; they serve as organs of feeling, as weapons and as instruments with which they procure their food. For this purpose they contain neuro-muscular cells and nettle organs. Their nutrition is accomplished by entodermal vessels which connect them with the digestive track. Thus the various elements are employed 
in the service of one or more than one function after which the organs are named. Accordingly there are organs of special sense, of respiration, of locomotion, of reproduction, of nutrition, etc. Especially among the higher animals several organs of the same kind and similar function occur in one and the same body. As such they are parts of a system of organs: muscular system, vascular system, nervous system, etc.

The question arises: How may the lowest, simplest. Metazoa have originated? Various theories have been advanced in answer to this question, most prominent among which is the gastraa theory, because it is founded upon a number of facts. It is highly probable that all Metazoa descend from one common ancestral for $m$, and that certain coinciding features in their embryology find an explanation in this common origin. The early stages in the embryology of the Metazoa present a definite plan which is expressed in the blastula and gastrula, both recapitulating ancestral forms common to all Metázoa.

In the first embryological stages of the Metazca there is forming a chief or primary axis, whose ends are termed animal and vegetative pole respectively, bcause in later differentiations of the two primary strata the ectoderm, developing around the aniunal pole, serves the functions of the animal splere (sense perception, locomotion), whilst the entoderm, developing around the opposite pole, performs the functions of vegetative life (nutrition). Accordingly the Metazoa present originally the uniaxillar, heteropolar structure. Frequently the primary axis can be recognized even in the ovum when the nucleus surrounded by dense formative protoplasm lies nearer the animal pole. It is there where the directive bodies or polar cells are expelled, immediately before fertilization. 
The process of egg segmentation with which after fertilization the embryonic development begins, is essentially a division of the ovum, steadily progressing according to definite laws, which result in the appearance of a number of still more undifferentiated cells (segmentation spheres, blastomeres). According to the direction which the planes of segmentation follow, we distinguish between meridional (lying in the plane of the primary axis) and equatorial (perpendicular upon the plane of the same axis) furrows. In this way blastomeres arise which at first assume the shape of a sphere, later on that of a pyramid, being radially arranged around an internal centre of the ovum. Soon, through the separation of the cells, a central cavity is formed, called the segmentation cavity or v. Baer's cavity (blastocelum), which constantly increases with the further development of the segmentations, while the blastomeres develop into a onelayered epithelium (blastoderm) surrounding this cavity. This stage in the embryology of the animal is called blastula or blastosphere. Even in the one-layered blastosphere, an arrangement of the parts around the primary axis is clearly recognized. The cells in the neighborhood of the animal pole are mostly smaller and poorer in food yolk, whilst those of the vegetative part are larger and richer in food-yolk, dividing more slowly on account of the impeding influence which the food-yolk exercises. The wall of the one-layered blastosphere presents the first primary organ of the nietazoan body.

From the blastula stage the gastrula is developed by the flattening and gradual invagination of the cell layer of the vegetative half, arising from the vegetative pole. In this process the primary segmentation cavity more and more disappears, and becomes often only an arrow split 
between the two layers of the body wall produced by this change. The gastrula stage assumes essentially a saclike form. It encloses an inner space, arisen by invagination, which is designated gastrocclom, opening externally in the region of the regetative pole by an aperture called the prostoma or blastopore. The cells of the animal part of the blastosphere now constitute the ectoderm; the vegetative half, which has become internal by invagination, forms the entoderm. In the region of the prostoma the ectoderm passes into the entoderm. Both lay ers constitute the two primary organs or germinal layers. The gastrula stage, typical with modifications for all Metazoa, appears as the recapitulation of a hypothetical ancestral form (gastrcea), distinguished by the development of the primary body cavity (gastrocœlom). Among the animals of the present time the Cnidaria have retained the essential structure of this ancestral form. In the higher forms modifications arise in the primary organs and with them differentiations of other organs. An intermediate layer, the mesoderm, develops between the ecto and entoderm. The entoderm retains its original functions of nutrition and digestion, forming the epithelium of the mid-gut, whilst the ectoderm furnishes the skin, the nervous system and the sense organs as well as the epithelium of the invagination of the fore-gut and hind-gut.

It often happens that the segmentation, the development of the germinal vesicle and the process of gastrulation are modified by the presence and definite stratification of larger quantities of food yolk, which of course changes the typical development of blastula and gastrula stage as given above.

Ova which are poor in food yolk (e. g., Amphioxus, Sagitta, Echinodermata) undergo the typical segmenta- 
tions explained above. Here are the blastomeres of almost the same size, those of the vegetative pole being slightly thicker. This phenomenon is termed total and equal segmentation, because the entire mass of the ovum is divided into blastomeres of almost equal size. The resulting blastula stage with its large central segmentation cavity is designated coloblastula or archiblastula whilst the gastrula following it bears the name of invagination or embolic gastrula.

The ova of certain Cnidaria, especially of the Hydroids, undergo a somewhat different gastrulation, although the process may be traced back to the one just stated. It is called polar invasion. The cells of the vegetative pole separate from the blastoderm, and enter the blastocœlom, which is gradually filled with a dense mass of entodermal cells. The gastrocœlom is only a secondary formation, and the mouth aperture arises through a dehiscence of the wall. The difference between this and the typical gastrulation lies in the fact that the entodermal cells give up their epithelial connection at the very beginning of the invasion.

There are cases, however, where a larger quantity of food yolk is deposited in the vegetative part of the ovum, so that the animal part appears to be considerably smaller. The results of segmentation, which is still total, show a relatively small segmentation cavity, situated eccentrically near the animal pole. The wall of the germinal vesicle, which may still be termed cœloblastula, shows in this case considerable difference in its density, corresponding to the animal and vegetative pole. This type of segmentation is termed total, unequal segmentation, whilst the forms belonging to this and the preceding type of segmentation are together called holoblastic ova. 
The total unequal segmentation may develop an invagination-gastrula, but the gastrocœlic lumen will be proportionately shallow on account of the small segmentation cavity. (Lamprey.)

In some other cases (e. g., certain annelids), a blastula stage is formed at the end of the total unequal-segmentation, in which the segmentation cavity is reduced to a minimum. A cell mass (Sterroblastula) results, in which a portion consisting of large entoderm elements rich in food yolk can be distinguished from another portion consisting of small ectodermal cells. The latter lies on the former like a cap. The gastrula stage arises by the growth of the edge of the ectoderm, which finally encloses the entoderm. This gastrula bears the name of epibolic gastrula (Sterrogastrula). The gastrocœlom is formed later as a split in the entodermal cell mass. The edges of the ectodermal layer must be considered as a blastopore. It is accordingly filled by a so-called yolk pling.

The presence of larger quantities of food yolk within the vegetative part of the ovum impedes the progress of its segmentation. In extreme cases of this kind segmentation may cease near the vegetative pole, and only a comparatively small portion of the ovum, consisting chiefly of formative yolk, may be divided into blostomeres. Such ova which undergo only partial segmentation are termed meroblastic, in contradistinction from those called holoblastic. A disc-like embryonic formation arises which, corresponding to the unsegmented mass of the food yolk, is situated upon the animal pole. This type represents the extremest case of unequal segmentation, and is termed discoidal, (found among the Cephalopoda, the Birds, Reptiles and many Fish). 
A special segmentation type is developed among the Arthropoda. Whilst the ova so far considered are telolecithal, i. e., contain the food yolk within the vegetative sphere, the ova of the Arthropoda show such an equal distribution of the food yolk that its centre coincides with the centre of the ovum (centrolecithal ova). The first segmentation nucleus lies in the centre of the ovum where it separates into a large number of nuclei, which are equally distributed along the periphery of the ovum, there causing the formation of a layer of small blastomeres of like shape. This layer represents the blastoderm, whilst the segmentation cavity of this bastula stage is filled with the unsegmented mass of the food volk. This process of segmentation is called superficial segmentation.

The modifications of development so far considered, appear chiefly to be conditioned by the quantity and mode of the distribution of the food yolk. There are still a few more forms to be mentioned, which indeed resemble, in their segmentation, the centrolecithal ova, but prove to be aberrant on account of the peculiar mode of their entodermal cevelopment. First of all is to be mentioned a form common among certain hydroids, generally termed entodermal development by delamination. It is most typical in the development of the Geryonida. After the formation of a coloblastula by means of total and equal segmentation, an internal portion, richer in food yolk, is separated from a superficial portion, poor in food yolk. Thus, from the single layered cell-sphere two concentric spheres arise, the jinternal one forming the entoderm, the external one the ectoderm. Gastrulation does not take place through invagination, the gastroccelom being produced from the segmentation cavity. 
A transition from delamination to polar overgrowth (so-called multi-polar invasion) has not yet been fully established, and the acceptance of a morula stage (without a segmentation cavity) formerly so prevalent, seems to be based on erroneous suppositions.

It has been shown that the chief axis of the gastrula stage connects the anterior or apical pole (animal) with the posterior or prostoma pole. This primary axis becomes in the lowest type of the Metazoa, i. e., the Porifera, Cnidaria and Ctenophora, the definite chief axis of the body. Hatschek, therefore, called these groups Protaxonia in contradistinction from the other Metazoa, the Heteraxonia or Bilateria. The latter name is due to a secondary displacement of the blastopore; the later chief axis of the body can no longer be traced back to the primary axis.

The stratified structure of the Metazoa becomes more complicated through the appearance of a layer of cells, which arises between ectoderm and entoderm, within the primary body cavity (remnant of the segmentation cavity) and is termed mesoderm or intermediate germinal layer. This name is used indiscriminately, without reference to the homology for all Metazoa. Among the Bilateria the homelogy of the mesoderm in all the groups may be accepted as probable. Some members of the Protaxonia show an independent development of the mesoderm.

The mesoderm of the Bilateria arises generally from the primary entoderm which divides into the mesoderm and the secondary entoderm. The usual mode of deve1opment, namely from two different primitive mesoderm cells, is early observed at the prostoma of the gastrula stage, where their position defines the median plane 
which intersects them. They move into the space between ectoderm and entoderm (primary body cavity), and form through proliferation the mesodermal streaks, two paired cell rows from which the organs of the mesoderm are developed. The other rarer mode of development, as found among the Chætognatha, Brachiopoda and Chordonii, consists in the formation of paired, sac-like diverticula of the gastrocalom, which become strictured and thus originate as independent cœlomsacs, the organs of the mesoderm. Both modes of mesodermal development are based upon one and the same plan, differing simply in regard to the separation of the mesodermal elements from the epithelium of the entoderm, which in the first case is rapid, in the second slow and more complicated.

In the later development of the mesoderm two types may be distinguished. In the one case the mesodermal elements loosen and completely fill the primary body cavity by the formation of a structure consisting of starshaped migratory cells imbedded in a jelly-like substance. This structure is called mesenchyma. (O. and R. Hertwig). By a separation of its cells, so-called lacunæ may arise, which on uniting may represent an apparent body cavity. Such cavities are termed pseudocoelom.

In. other cases most of the mesoderm disappears in the formation of paired sacs, called colom sacs, in whose walls the mesodermal cells have epithelial connection. The sac cavities represent the genuine body cavity or colom. The paired cœlom sacs completely enclose the intestinal canal, and form in the median line above and below it the so-called mesenteries. The body cavity separates the mesoderm in two layers. The external 
layer, adjoining the ectoderm is called the somatic layer, the internal layer adjoining the entoderm is called splanchnic layer.

In some animals (Plathelminthes) the mesoderm furnishes, besides, or aside from its specific organs (of reproduction and excretion) only mesenchyma. But in the majority of the Bilateria the formation of mesenchyma and cœlom are contemporaneous and, as it were, competitive, so that in one case (Annelids, Sagitta, Pharonis), the latter, in the other (Mollusca, Arthropoda) the former predominate.

From the mesoderm of the Bilateria are derived the muscles, genital organs, nephridia, connective tissue and fatty tissue.

The following table presents the different modes of segmentation. (See table of Hatschek's classification.)

TABLE,

\begin{tabular}{|c|c|c|c|c|c|}
\hline Equal. & $\begin{array}{l}\text { Porifera. } \\
\text { Cnidaria. }\end{array}$ & Scolecida. & $\begin{array}{l}\text { Annelida. } \\
\text { Crustacea. } \\
\text { Mollusca. }\end{array}$ & $\begin{array}{l}\text { Echino- } \\
\text { dermata }\end{array}$ & $\begin{array}{l}\text { Tunicala. } \\
\text { Amphioxus } \\
\text { (amovg Mamma. } \\
\text { lia in secondary } \\
\text { form.) }\end{array}$ \\
\hline Unequal. & $\begin{array}{l}\text { Porifera. } \\
\text { Cnidaria. } \\
\text { Ctenophora. }\end{array}$ & Scolecida. & $\begin{array}{l}\text { Annelida. } \\
\text { Crustacea. } \\
\text { Mollusca. }\end{array}$ & $\begin{array}{l}\text { Echino- } \\
\text { dermata. }\end{array}$ & $\begin{array}{l}\text { Pelxomyzontida } \\
\text { (Lampreys). } \\
\text { Ganoidei } \\
\text { Amphibia. }\end{array}$ \\
\hline Discoidal. & & & Cephalopoda. & & $\begin{array}{l}\text { Selachii. } \\
\text { Teleostei. } \\
\text { Reptilia. } \\
\text { Aves. } \\
\text { Monotremata. }\end{array}$ \\
\hline Superficial. & & & Arthropoda. & & \\
\hline
\end{tabular}

Note: The ilalic type shows the predominant segmentation.

The successive division of the egg cell results in the 
formation of groups of cells which are united in their functions to so-called tissues. Tissues of one or more than one kind form the organs of the body. The higher the animal the more specialized becomes the division of labor, i. e., the physiological functions of the various tissues. This leads us to the consideration of Metazoan histology. Here, two factors' are to be emphasized : (I) the lamina of the cells; (2) their structure and their products.

The epithelium is the oldest and most important ground-form of the Metazoan tissue. It consists of cell masses arranged in a plane, and is already met within the blastoderm of the blastula, where it is a simple layer, and therefore called one-layered. It presents two planes; an external open plane and a basal plane turned towards the blastocœlom. Accordingly, each epithelial cell has two poles, a free pole and a basal pole. Both planes possess in all cases opposite characteristics. One-layered epithelia are classified according to their form into cylindrical, cubic, and pavement epithelium. Stratified (of several layers), epithelza (in skin of vertebrates), are not of the same formation throughout, (flat above, round below), it is, however, of rare occurrence that a complete separation into lamina (delamination) takes place.

Tissues; originally consisting of connected epithelial tissues, often change in mode of layering and surface formation. They are called epitheliogenous.

Individual basal cells of the epithelium may enter the blastocœlom in an amœboid form, and thus be degraded to apolar cells. (Mesenchyma cells). They may differentiate into tissues (mesenchymal tissue) and develop again epithelia of internal cavities. Such formations are termed pseudo-epithelia or epitheloids. 
All histological differentiations proceed from the cell plasma, the neuclus retaining its typical character. $D i$ rect plasma differentiations manifest themselves in certain plasma functions (contractility, irritability) in a high degree (muscular and nervous substance). Other differentiations are simply products of the plasma. The former are called autoplasmatic, the latter apoplasmatic structures.

I. Autoplasmatic structures. External plasmoid cell-formation. Pseudopodia. They have the same functions as those of the Protozoa. Amoboid epithelial cells occur in embryonic forms for the purpose of yolk reception; in the ectodermal epithelium of fully developed sponges, and in the entodermal epithelium of all the various lower and higher Metazoa for purposes of nourishment. Amoboid mesenchyma cells retain their original form in the embryonic mesenchyma cell and in the free connective cell (wandering cell). Similar to it are the amoboid pigment cells, where pseudopodial change of form brings about change of color; finally amoboid (or white) blood corpuscles. Vibratile, hairlike processes are present on the free surface of all epithelial tissues (except in certain protonephridial canals). There may be either one on the surface of each cell, called flagellum, or many, called cilia, or a compound flagellum or compound cilia (ciliated plates). The Arthropoda, Nematodes (and Acantocephali) are without these processes. They perform functions of locomotion (small ciliated swimming Metazoa and larval forms), of feeding (around the mouth of Rotatoria), of digestive respiration (ciliated epithelium of intestinal canal); of pulmonary respiration (ciliated epithelia of gills).

Epithelial cells which possess at their free end sensory hairlike processes and are at their basal end connected with 
nerves are termed sensory cells. These sensory processes are either sensory hairs (of hearing or touch), or bristles or rods (eye). The last named may assume various modifications and even be found in the interior of the plasma of the visual cells. The bristlelike processes on the free surface of the epithelial thread cells of Cnidaria are called cnidocils. They all have sensory functions.

Internal plasmoid cell formation. Muscular fibrils and tissue. Structural. The muscular fibril arising as the contractile element within the plasma of the muscular cells (myoblasts) is a threadlike, pellucid substance of varying lengths, either pointed or blunt (rarely forked or netted) at the ends, which, arrayed in bundles or in strata, constitutes one or several cells. In smooth fibrils the contractile substance is continuous, in cross-striped fibrils it is divided into sarcous elements, which are separated by non-contractile disks. The difference between the two kinds of fibrils shows a difference of function. Muscles frequently and voluntarily used, also those of heart, present a striated appearance and are mostly found among the Vertebrates.

The myoblasts are either epithelial muscle cells, with a muscular process at their bases, and possessed of various functions, or muscle fibres, situated in the deeper parts of the body, and having the appearance of a piece of cord. They consist of an external membrane (sarcolemma), of fibrils and a small portion of unchanged plasma (muscle corpuscles). Genetically one kind of muscle fibre is more closely related to the epithelial muscle, the other to the mesenchyma. There are, therefore, three kinds of muscular tissue: Epithelial muscles, epitheliogenous muscles, and mesenchymal muscles. Epithelial muscles belong exclusively to the Cnidaria. They arise on' the basal sur- 
face of the epithelial cells, running parallel to one another in definite directions. A massing of fibrils, (rarely by stratification), is mostly due to a longitudinal folding of a single fibrillous layer which thus may become very high. The epitheliogenous muscles of the Cnidaria arise through a constriction of the fibrillous folds which form with their myoblasts subepithelial cord-shaped structures. Delamination between surface stratum and myoblastic stratum occurs but rarely. Among higher animals a large portion of muscular tissue arises from the epithelium of the cœlom, and its mode of separation shows innumerable degrees of gradual variation.

The mesenchymal muscle fibres originate phylogenetically in the gelatinous substance which fills the blastocœlom of the lowest Metazoa. Primarily they exist as single fibres. Tissue masses are secondary formations. They are present.in some Porifera, in the Ctenophora; in the lowest worms exclusively; hardly in higher worms; very prominently in the Molluscs, and somewhat in the intestinal muscles of Echinodermata, and the Vertebrates. The movements of the smooth muscle fibres are slow, but much more intense than the quick movements of the striped muscles.

The essential elements of the nervous system are ganglion cells and nerve fibres. It appears in the lowest form as a ganglion-plexus spreading like a net within and throughout the epithelia (Actinia); whilst in higher forms numerous ganglion cells unite to so called ganglia, whence the nerve fibres branch out in bundles, as nerves, becoming thinner and thinner towards the periphery, until they consist of only one fibre, which may again join a ganglion-plexus. The structural element of nervous tissue is the nerve fibril (primitive fibril). It is a very 
thin, simple thread, with characteristic little knots. A number of them surround concentrically the nucleus of the ganglion cell, continue radially into the contents of the nerve fibre (which in its peripheral anastomosis separates into fibrils), and may finally penetrate the interior of the peripheral cells (e. g., the sensory cell or muscle fibre.)

Ganglion cells are round, have a large nucleus within rich fibrillous protoplasm, and possess one or more processes (unipolar, bipolar, multipolar, ganglion cells). These processes may either continue as a nerve (nerve or axis cylinder process) or form an anastomosing network (plasma process). The nerve fiber consists essentially of the axis-cylinder which is of varying diameter and of a slimy character. In its simplest form it is without a surrounding fatty marrow (non-medullated), and as such it is present in all Invertebrates and some lower Vertebrates, as well as in the sympathetic and olfactory nerves of the Vertebrates. The axis cylinder possessing a double contour (medullated) is present in all Vertebrates. Besides, in the peripheral nerves of many Vertebrates and the Arthropoda a nucleated sheath (Schwann's) surrounds the axis cylinder, whilst in the central nervous system it is enveloped by a continuous tissue of fibrous cells (neuroglia or glia cells). The same may be said of the envelopment of the axis cylinders of peripheral nerves among Annulata and Mollusca. Axis cylinders of peripheral nerves are perhaps only lengthened processes of central ganglionic cells.

Peripheral nerve-ends generally combine with cells of widely varying functions, among which may be mentioned sensory and muscular cells. The former join the nerve at their basal pole; the latter along the side of the 
fibre, where the nerve ends in a plate (striped muscle fibre of Vertebrates and Arthropoda). The same can be said of the muscle fibre of the Vertebrates and mesenchymal muscle of the Invertebrates. (The smooth muscles of the Vertebrates are enveloped in a fine nervous network.)

The stratification of the nervous tissue is either epithelial or epitheliogenous.

The epithelial nervous system of the Cnidaria is of special importance for nervous phylogeny. In the ectodermal epithelium of the Actinia are present the following sensory and nervous elements: Sensory cells on the free surface, ganglion cells in the middle and nerve masses near the base, (muscular cells beneath if such are present). The nerves form a network with the sensory and ganglion cells.

The Hydromedusæ and Scyphomedusæ present the beginning of a central nervous system. This always develops whenever sensory organs arise. The formation of such organs depends upon the stratified accumulation of sensory cells and nervous elements, as mentioned above; all other cells, except supporting cells, are absent. Such a specialized epithelium is termed a nervous sense-epithelium. The Scyphomedusæ possess eight ganglionic centres, radially distributed, in connection with eight groups of sensory organs. Among the Hydromedusæ the central nervous system assumes the form of a ganglionic ring which stands in connection with sensory organs, the body epithelium being interlaced with a fine nerve plexus. The nervous system of the higher animals (Heteraxonia), is always central, but may retain its epithelial position. Not only the central nervous system and sensory organs but also the beginnings of the peripheral nerves of many Annulata (Sagitta), Brachiopoda, Echi- 
nodermata, and of Balanoglossus, develop from and lie within the ectodermal epithelium. The sensory epithelia of the sensory organs consist largely of sensory cells, ganglion cells, nerve fibres and supporting cells; the nerve epithelia of the central system of ganglion cells, nerve fibres and supporting cells; the nerve epithelia of the peripheral system of nerve fibres and supporting cells. Stratification is the same as among the Cnidaria.

The nervous system of the most highly developed animal gives up its original epithelial position and seeks a more protected situation within the body. Thus its anatomical separation becomes perfect. Those groups of animals which show all the transitions from the epithelial to the epitheliogenous nervous system, often within the same body, are of special interest, because we observe, that anatomically and histologically the epithelial supporting tissue gradually develops the glia substances of the nervous system.

The separation of the central nervous systems occurs either by delamination or by invagination. The first mode is predominant among the Invertebrates. The ganglionic and nerve layer, together with the deeper layer of supporting cells, separates from the surface layer. The other mode is predominant among the Vertebrates. A part of the ectoderm along the dorsal surface of the embryo caves in towards the interior of the body, separates and forms an epithelial free tube (medulla), becoming through histological differentiation a nerve epithelium. The stratification is here the same as among the Cnidaria. (Amphioxus a good example.)

The sensory epithelia either lie in the same plane with the other ectodermal epithelium or form deeper invaginations. Often they separate in form of bladders (eye blad- 
ders, auditory bladders, touch bodies). There are two kinds of sensory epithelia: stratified epithelia, which possess beneath the sensory cells a ganglionic layer and a basal nerve layer; simple epithelia, consisting only of sensory cells, to whose basal termination nerves are at. tached. Often a peripheral or sensory ganglion lies near the simple epithelium. A comparison between the development of the vertebrate retina and that of a cephalopode furnishes an interesting illustration for the fixed arrangement of stratification.

The development of peripheral nerves is only traceable among the Vertebrates. They arise as outgrowths of the central nervous system, uniting secondarily with their terminal organs.

The functions of the nervous tissues are complex, beginning as crude irritation in the simple cell plasma of the lowest animals, and reaching their highest differentiations with the complete division of labor in the minutely organized nervous system of man. Sense organs, nervous organs and locomotory organs stand in necessary mutual relation to one another, just as sensation and the resulting action bear a necessary relation to each other. Specialization is carried so far that each form of sensation has its special apparatus of transmittance to the central nervous system. In many lower animals the ectodermal epithelium performs all the functions of sensation (touch, light, heat, chemical irritation) and is, therefore, to be considered as a primitive sensory organ. From this the special organs developed. First, the integumental sense organ. They are either isolated sensory cells (Cnidaria), or sensory buddings, groups of sensory cells, often surrounded by a concentric zone of supporting cells, connected together by a nerve 
fiber (higher Invertebrates). The epithelium of the Arthropoda secretes a chitinous cuticle with hollow bristle and hairlike processes; special cells of the matrix send thin plasma threads into these processes, and perform the functions of cells of touch, since they are connected with a nerve at their base. Vertebrates living in water show the same integumental sensory organs, appearing either as solitary cells, or as cell buds, as free nerve terminations or as so-called lateral line organs of the fish. Organs of touch lying in the cutis appear also in the form of peculiar sensory cells among the terrestrial Vertebrates.

Organs of taste and of smell perform the function of testing the food preparatory to the various modes of metabolic changes. In the lowest animals the sensory cells of taste are like those of touch, and are only distinguished by their position in or around the mouth opening. The organs of smell of the Invertebrates have the form of papillæ, with vibrating epithelium, containing vibratory and sensory cells. It is situated near nerve centres or higher sensory organs. The Crustacea perform the functions of taste and of smell by means of so-called olfactory hairs situated along the first pair (rarely also on second) of the antennæ, and filled with plasma, which, through a round cell (sensory cell?) connects with a nerve fiber. The olfactory organs of the insects are situated along the antennæ, their organs of taste along the palpi or inouth cavity. Both arise from the chitinous trichome. The sensory elements are coneshaped and lie, single or in groups, either free on the surface of the chitinous cover or in a papilla. The membranous canals of the antenna are modifications of these organs. The olfactory organs of the Vertebrates 
resemble originally the structure of paired ciliated papillæ lying in the anterior end of the head. Afterwards they move interiorly; nose cavities arise without sensory epithelia. They open in the mouth cavity, and serve as air passages. Their olfactory epithelium consists of high ciliated cells and sensory cells with free sensory hairs.

The sensory cells of the auditory organs resemble the primitive cells of touch in form and function. They always require an auxiliary apparatus to receive the sound waves. In certain Hydromedusæ tentacle formation are changed into auditory vesicles whose entodermal axillary cells carry otoliths and whose octodermal sensory cells carry sensory hairs, which are set in motion by the sound waves. The deeper the position of these vesicles the higher is their function. The auditory vesicles of the Leptomedusæ are of independent origin arising radially along the edge of the disk as numerous invaginations of the ectoderm. The otoliths lie in the ectodermal, cells and communicate through vibrations with the neighboring sensory cells.

The auditory organs of Turbellaria, Annulata and Mollusca (exclusively) are vesicles derived from the ectoderm containing one or more calcareous secretion products (otoliths) suspended by ciliated cells. The wall of the vesicle contains sensory cells which send hairs into the lumen.

In spiders and mites the auditory organs are absent. In the higher Crustacea they are at the base of the first antennæ, consisting of epithelial sacs opening externally. They are internally covered by a continuation of the external chitinous epithelium, upon which rows of very active auditory bristles are situated; grains of sand enter from the outside and act as otoliths. 
Auditory organs are peculiar and numerous in the insects. They are groups of cells which are stretched like the cords of a musical instrument through the body cavities, fastened by a ligament at opposite ends of the integument, to one of which the nerve is attached. This group of cells contains ganglion cells and sensory cells, the latter containing peculiar bodies called auditory rods. In musical insects a trachea forms a tympanum, lying directly under the thinned chitinous membrane, thus perfecting auditory functions. These organs are situated in different insects at different places.

The auditory organ of the vertebrates undergoes the simple vesicular development, in which condition it often contains otoliths, and is capable of performing functions (in embryonic teleosts). This vesicle develops into a labyrinth with peculiar characteristics. In it auxiliary apparatuses arise which conduct and magnify the sound (external ear, tympanum, auditory ossicles). The physiological function in distinguishing sound differentiations depends upon the transmittance of these sounds upon the auditory cells by means of auxiliary apparatuses (fibres of membrana basilaris).

The simplest eyes consist of a small number of sensory cells (even of only one) which on one side are covered by a goblet-shaped, opaque mass of pigment, so that light can penetrate the sensory cells only in one direction (visual axis), which is observed by the animal. Such eyes are called euthyscopic (or directing) eyes.

The Cnidaria possess such pigmented spots of senseepithelia, in which each sensory cell is surrounded by supporting cells. They are called ocelli. The eye of the Turbellaria and Rotatoria possesses in addition a light refracting apparatus or lense, which however only serves 
the function of intensifying the light-effect. The transition from the euthyscopic to eidoscopic eyes, i. e., eyes which perceive a picture, generally takes place by an aggregation of the former. A large number of luminous elements, i. e., sensory cells with their specific terminations, which are connected with separate nerve elements, are necessary in order to see a picture. The sensory cells compose a sense epithelium, which is here termed retina. The larger the number of the luminous elements of the retina, the more detailed is the perceived picture. This differentiation of separate sensory cells with separate nerves for the perception of separate sensations, is called the nervous isolation of the perceiving elements. A second necessity is the optic isolation of the perceiving elements, which is to prevent a general diffusion of light upon the retina by admitting only the rays proceeding from single definite objects. This is done in various ways. We therefore distinguish different types of eyes. The most perfect eyes are the camera eyes, which possess special light-refracting apparatuses for optic isolation. The eye of the vertebrates belongs to this type. The human eyeball consists of a hard cuticle (sclera), an external firm connective tissue layer, which passes anteriorly into the cornea, a convex transparent horny cuticle, with an external transparent epithelial layer. From the interior of the sclera arises the chorioidea, a second connective tissue layer, rich in blood vessels and dark pigment, continuing anteriorly as a contractile membrane, the iris, with an open circular centre and a thickened muscular ring, the ciliary body as its root. The next interior layers are the black pigment epithelium and the bright retina. Not far from the ciliary body, at a line called ora serrata, the nervous character of the 
retina ceases, and becomes a pigmented layer, which, together with the pigment epithelium, forms a double layer, and extends to the free edge of the posterior surface of the iris. The anterior eye chamber between cornea and iris, is filled with aqueous humor, whilst the posterior eye chamber, behind the iris, contains the lens, ontogenetically derived from the external epithelium. The lens capsule is fastened by connective tissue fibres (zonula Zinnii) to the ciliary bodies. Behind the lens the cavity of the eyeball is filled with the corpus vitreum, a less pellucid, transparent connective tissue substance. The optic nerve, entering the eyeball not quite parallel with the optic axis, penetrates the retina and continues in its nervous layer. Then follow the two ganglionic layers, the optic cells, and finally the rods which are turned towards the pigment epithelium.

The picture is projected upon the retina (reversed as in a camera), after the rays of light have been deflected three times; in aquatic animals the deflection of the rays in passing from the water to the cornea is but slight, and the work is largely done by a strongly convex lense, following the laws of optics. The eye is adjusted or accommodated to different distances by changing the form of the lens by means of the ciliary muscles.

The eyes of many Invertebrates (especially Cephalopoda) are of similar physiological structure as those of the Vertebrates, but they are morphologically different; the rods of the retina are turned towards the eye pupil. Eyes of insects and spiders, without facilities for accommodation, are probably only for definite distances.

The compound eyes of the Crustacea and Insecta are termed convex musivian eyes, a second physiological type of the eidoscopic eye. The perceiving elements of the 
retinæ are here groups of cells, called retinula. In the centre of the retinula is a rodlike structure, the rhabdom, consisting of as many rhabdomens as there are cells, and surrounded by a pigment mantle. The anterior part of the pigment tube is filled with the so-called crystalline cone. The external transparent cuticular chitinous cover of the eye, called cornea, is divided into very regular hexagonal facets, often thickened and thus representing each a lens (comeal lens). Only a very small cone of rays reach each retinula, which lessens the strength of the light, showing the eye to be inferior to the camera eye. No apparatus for accommodation is needed; the animals can see in the air as well as in water.

The concave-musivian eye of Atrhropoda and Mollusca is based upon the same optic principle as the preceding. The axillary rays of light proceeding from the object to the elements of the retina intersect in front of the latter, and throw apparently a reverse picture upon its surface. Only one lens suffices for all retina elements, but only the central rays are of use here, whilst those of the circumference are absorbed by the pigment. Wherever the lense closely approaches the retina, i. e., where the formation of a picture is impossible, and where the retina is pigmented throughout, there we have a concavemusivian eye.

There are transitions from the lowest to the highest eidoscopic eye, based upon the distance of the lens from the retina and its proper correction.

Morphologically the eyes are divided into cup-shaped, vesicular, inversely vesicular and compound eyes. The first form a cup-shaped depression of the epithelium. The retina continues laterally into the epithelial cells. In their simplest form they are concave-musivian, when $\mathrm{D}^{*}$ 
a cuticular or secretory lens is present, and in proper position they are camera eyes. The second form arises when the optic depressions or papillæ form a vesicle and separate completely from the epithelium. The free surface of the epithelium becomes the interior of the vesicle and forms posteriorly the retina, anteriorly the internal pellucida, whilst the basal surface of the epithelium becomes the exterior of the vesicle, producing posteriorly the nerve, anteriorly the external pellucida. A lens is always present, undergoing modifications in certain cases. In their simplest form they are concave-musivian eyes, but go through all the higher gradations. The third form develops from a vesicular structure called the primary eye vesicle, which in the Vertebrates arises by constriction from the medulla tube-in Invertebrates by direct invagination of the external epithelium. The anterior half of this vesicle invaginates, forming, with the posterior half, a double-walled cup called, secondary eye cup. Its anterior part furnishes the retina; its posterior, a pigment epithelium; here also the rods arise, whilst the nerve develops from the opposite surface of the retina. The lens is always a cellular structure which is independent outside of the primary eye vesicle. In the fourth form (a. facetted eyes of Arthropoda) every element of the eye corresponds to the two-layered cup eye of the Myriopoda, an aggregation forming the compound character, which aids co-operation but lowers individual ability. Embryologically they arise from a thickening of the epithelium, in which already the ommatea (retinula with crystaline body) separated by sheath cells (pigment) may be recognized. The ommateum itself consists of the crystalline cells (upper layer) surrounded by the chief pigment cells, and of the retinula 
cells (lower stratum) to which a nerve is attached. The ommatea become high and narrow and the cuticular cornea arises, often enlarging to a lense above each eye. According to the differentiation of the crystal cells there are: (I) acone eyes (crystal cells representing crystalline body); (2) eucone eyes (cells secrete a crystalline cone); pseudocone ey'es (transparent pseudocone arises before the crystal cells).

The compound eyes of Crustacea are phylogenetically different from those of the Insecta, but resemble them very decidedly, having cornea, crystalline cells and cones.

b. Middle cup eyes of Scorpion show composition of retinulæ. The simple cup eyes of the Myriopoda constitute the origin for several different embryological developments among the Tracheata.

II Class. APOPlasmatic STRUCTURES. Internal cell formations. Water vacuoles may arise both in epithelial and mesenchyma cells. They become especially conspicuous in the endodermal cells of the Cnidaria and in the cells of certain supporting tissues (connective tissues), which are greatly extended by them; such tissues are the endodernal tentacle axes of the Hydroid polyps and of the medusæ as well as the chorda dorsalis of the Vertebrates and the saclike connective tissue of Plathelmynthes and Mollusca. Fat globules are present, especially in the endermal cells of the lower animals, forming numerous little drops. The so-called fatty tissue of Insects and Vertebrates contain fat cells in which fat globules are deposited. Pigment granules of various kinds are secondary formations in the plasma of certain cells, where they produce district colorations. They are of special interest in the eye, as mentioned above, and in their 
amœboid form, as found beneath the body epithelium. The power of changing the color is due either to an independent contractility of stuch cells or to muscle fibres which are attached to them (as in Cephalopoda). Intracellular skeleton formations arise most frequently in the mesenchyma cells of the sponges (resembling those of Forminifera and Radiolaria) as calcareous needles and silicious bodies, which, however, during growth break through the cells. We can, therefore, hardly distinguish between inter-and intra-cellular formations. The calcareous skeletons of the Echinodermata may be of similar origin. In this connection, the epidermal formations of the Arthropoda (chitin) and the higheI Vertebrates (nails, hoofs, claws) should also be mentioned. Nematocysts are peculiar, complicated, envelopes of certain cells; they are thick-walled papillæ which contain a fluid and a nettling thread spirally rolled up, and are especially found in the epithelia of the Cnidaria, Turbellaria and Folida.

CELI SeCRETION: Glandular tissues. Secretions are generally excluded from the cell and also from the body. Such cells are called glandular cells, and are epithelial in their character. Unicellular glands lie either within the other epithelial cells (goblet cells, granular cells, etc.), or beneath them when they are differentiated into gland and duct. Multicellular glands arise when all the cells in a certain part of the epithelium become glandular and undergo invagination, which differentiates into gland and non-secretory duct. They are either tubulous or acinous. Secretions may serve definite purposes (digestive glands, poisonous glands, protecting envelopes and shells of Mollusca and of Brachiopoda, ectocysts of Bryozoa). 
External cell secretions arise along the periphery of the cells, originating the real connective substance. In its most primitive form it is the cell membrane; it develops also the yolk membrane of ova and the sarcolemma of muscle fibres. Similar secretions appear (I) in epithelial tissues as a cement between the cells, sometimes separating them and forming isolated cells; or as a basal membrane, a thin but very fine secretion under the epithelia, sometimes of fibrous structure; or as cuticula, a membrane lying on the free surface of the epithelia. In some groups (Sponges and Vertebrates) it is not developed; in others (Nematodes and Arthropoda) it becomes stratified and influences most profoundly the whole organization. Endodermal epithelia form a so-called rod cuticula, a thick, superficial layer perforated by fine canals. Such secretions appear (2) as the fundamental substance of the different kinds of connective tissue. A cement substance is likewise secreted by mesenchymous cells forming the so-called genuine connective substances, especially of the Vertebrates. The different kinds of connective tissue show different structures of the fundamental substance. Hyaline cartilage has a homogeneous, elastic, firm, fundamental substance, round cartilage cells without blood vessels. Fibrous cartilage shows fibrous structures in the fundamental substance. Fibrillar connective tissue is soft, but tough, its cells are spindle-shaped; elastic tissue is nearly related to it. Bony tissue is fibrillar but very firm and hard through the deposition of calcareous matter; it is characterized by its stratification. We must therefore distinguish between incrusted cartilage and genuine bone tissues. "The former is cartilaginous tissue, hardened by the deposition of calcareous salts. 
The gelatinous tissue of the Cnidaria found between the two primary layers, is free from cells in the Hydromedusæ whilst the Scyphomedusæ show mesenchymous cells and fibrous structures.

FLUID SUBSTANCES OF THE BODY are contained in the primary body cavity, in the cœlom, and in the blood system; they differ morphologically, consequently also the corpuscles derived from them. The fluid of the first two cavities is called lymph, that of the third blood. It consists of water, in which albumen and salts are dissolved. The water has to permeate first the surrounding tissues by which it is chemically affected. Free cells are also present in the fluids, which are either white blood or lymph corpuscles or red blood corpuscles, whose coloring matter, hamaglobin, serves the purpose of oxidation and deoxidation. They are generally found in Vertebrates (except Amphioxus) and a few Invertebrates (worms).

The functions of the Metazoan body may phylogenetically be divided into those of the ectoderm and those of the entoderm. Metabolism includes nutrition, respiration, excretion and circulation. The first process of nutrition is assimilation, which is chiefly carried on by the entodermal epithelial cells of the digestive canal. They perform the functions of the digestive activity and of the resorbing activity. In the sponges digestion is carried on by the whole body, and is termed geneval intracellular digestion; in the Cnidaria and Turbellaria it manifests itself as (special entodermal) intracellular digestion, i. e., solid food particles are taken up and liquified by the entodermal cells. In the higher animals it is called extra-cellular digestion, because the phenomenon oceurs within the digestive canal, 
whilst the epithelial cells resorb the food (already liquified). The division of labor is carried still further when the digestive apparatus is differentiated into stomach, glands, anus, etc. The distribution of food in the body is carried on in various ways in the different groups of animals; in the Sponges by the amœboid activity of the body cells, in Cnidaria by a multifarious branching of the digestive canal, until in the higher animal a special differentiation of vascular systems (blood-1ymph) is called into assistance. The reception, distribution and elimination of gases (oxygen and carbon dioxide) are carried on by the functions of respiration, either by the whole ectodermal layer of the body (in the lowest animals) or by an evagination (gills) or invagination (lungs) of the body wall, aided by the system of circulation. The tracheæ and tracheal gills of the Insects deserve special explanation. The process of excretion or the separation of urine and related substances calls into coöperation all the tissues of the body. Of great importance are the various methods by which these nitrogenous excretions are collected into special organs and thence carried out of the body. In the lowest forms there are no special organs of excretion present; in Cnidaria and Ctenophora numerous unicellular glands of ectoderm or entoderm perform excretory functions, whilst in the Hydromedusæ openings along the peripheral branches of the digestive apparatus have been observed. In the lower worms a protonephridium (or water vascular system) is present, a paired tubular formation, either simple or branched, in which strong ciliation is developed. In the Annulata, Arthropoda, Mollusca and Molluscoidea the protonephridium is only present in the embryo; it is replaced in the adult animal by the metanephridium, an apparatus 
consisting of glandular ciliated tubes, connected by an internal opening with the cœlom cavity, and opening externally on the surface of the body. It is differentiated into a ciliated funnel; a canal, covered with vibratory threads and a muscular terminating bladder. The first receives the fluid from the colom cavity, the second furnishes the excretory substances, and the third serves as a reservoir. In the Vertebrates the apparatus is termed kidneys. It consists of segmental canals, similar to those of the segmental organs of the Annulata and of kidney ducts (Wolffian duct), probably derived from the external epithelium and running along the body, near, but outside of the splanchnocœlom. The differentiations are varying.

A system of circulation is found only in those animals which have a secondary body cavity (cœlom cavity). It is, of course, wanting even among some of them. The walls of the blood vessels consist of two layers, an internal epithelial layer and an external muscular layer; numerous differentiations are possible. The blood system is either closed, i. e., it does not communicate directly with the cœlom cavity (Annulata), or it is open, when it merges into other body cavities, as we find it among the Mollusca. The development of a heart is somewhat complicated, beginning as a mere pulsating differentiation in the simple vessel, and reaching its highest form in the perfect double vessel of the Vertebrates. The circulatory system of the Vertebrates is divided into three distinctive parts: the arteries, which conduct the blood from the heart to the organs; the cap. illaries, which form the fine anastomosing net within the organs; and the veins, which collect the blood and conduct it back to the heart. The relation of this system 
to that of respiration is of the highest physiological importance. In the Invertebrates there is a so-called body heart; the blood empties from the heart into the body, thence into the gills and back to the heart. The Cephalopoda have special gill hearts, while in the Annulata the flow is direct from the body into the gills. Further differentiation results in the gill heart of the fish, then in the incomplete double circulation of the Amplibia (where the circulation of the lungs is separate from that of the heart, but the blood of both mixes), reaching finally the climax in the complete double circulation of the highest Vertebrates, where a body heart and a ling heart are distinctly separated. The blood flows from the former into the body, thence into the lung heart, through this into the lungs and back to the body heart. The form of the heart gradually changes from the periphery towards the centre, culminating in the four-chambered organ of the highest animals.

The fundamental phenomena of locomotion are the same in the Metazoa as in the Protozoa: Amceboid locomotion, plasma contractility, ciliary locomotion and muscular contractility. They may all occur at the same time in the same body, but the last one is of greatest importance. Amœboid locomotion serves mostly the purpose of distributing the food throughout the body (Amœboid migratory cells, white blood corpuscles, $1 \mathrm{ymph}$ cells); it also brings about the removal of injurious bodies, and plays an important part in embryonic development. Plasma contractility is similar to the first, and occurs in all tissue-cells which contain protoplasm. Ciliary motion is prevalent among the lower Metazoa, because only small organisms can be moved by it. Muscular contractility takes place among all Metazoa, and depends upon the nervous system. 
Phylogenetic and ontogenetic development of the tissues. Simple tissues consist of cells which are alike in composition and function. A division of labor produces mixed tissues, whose cells are different in structure and function. A further differentiation leads to specialization, and a division of labor among the cell complexes or tissues occurs. Each tissue is simple but specialized. When specialized tissues grow into each other, compound tissues arise.

Ontogenetically the specialization of tissues (histogenesis) is direct, but the development of the differentiations is gradual, representing a repetition of phylogenetic process. The relation of the germ layers to the tisswes has not yet been finally established, but it may be permissable to give the following survey of the histogenetic function of the germ layers of the Vertebrates:

Ectoderm: External epithelium and epithelium of the cuticular glands, nerve tissue, sensory cells.

Entoderm: Epithelium of the intestine, of its appendages and glands, chorda, epithelium of blood vessels and blood (?)

Mesoderm: Epithelium of the body cavity, germ epithelium, glandnlar epithelium of the kidneys, muscular tissue, connective substance.

Modes of Reproducton. Reproduction is the goal of all active existence. The lower an organism is the more pregnant becomes this fact. Posterity is procured in many different ways. We mention sexual reproduction first. An animal may either produce large masses of very small eggs so that many small and imperfect individuals are born which have to undergo a number of changes before they reach maturity (metamorphosis), or it may produce few, but large eggs, rich in yolk, 
which bring forth individuals comparatively well developed (without metamorphosis). The existence of a new individual is still more fully assured wherever special care in the parental body or under parental supervision exists. The chief mode of reproduction among Metazoa is sexual reproduction. It requires a mixing of individuals and thus becomes necessary for every species. We distinguish animals with separate sexes from those in which both sexes are in one individual, called hermaphrodites. The latter phenomenon is a secondary adaption to nerv conditions. In both cases the crossing of two individuals is the normal requirement. Many lower animals simply eject their sexual products into the water, leaving the union of male and female form to mere chance. The higher animals pass through a complicated process of copulation, which saves reproductive material. Between these two modes there are a great many modifications. Sometimes the spermatozoa alone are ejected into the water which carries them into the maternal body (into the tissues of the Sponges, into the ovaria of Chrysaora, into the gills of some Mollusca). In the transition towards copulation male and female live together. Whilst the latter deposits the eggs the male covers them with spermatozoa (Teleostei). External copulation takes place among the frogs. Genuine or internal copulation is usual among all terrestrial and many aquatic animals. Most insects keep the spermatozca in the receptaculum seminis until the egg is ripe for fertilization and ready to be discharged. Reptiles and birds lay their eggs during the first stages of segmentation. Those of the birds cease to develop until incubation begins.

The organs of copulation consist in the male of a 
vesicula seminalis, a ductus ejaculatorius and (mostly) of a penis : in the female of a vagina (frequently together with a receptaculum seminis). The modifications of the penis of some Crustacea, the spiders and the Cephalopoda, deserve special mention. The distinctive characteristic (dimorphism) of male and female are largely confined to the reproductive organs, but other modifications (of size and color) arise when the conditions require such. The most interesting investigations of this kind have been carried on by Kowalevsky and Darwin (dimorphism of Bonellia and heterogeny of certain Nematodes).

Parthogenesis or reproduction from unfertilized eggs is derived from sexual reproduction without fertilization. According to Weissmann, only one polar body develops, instead of two. Occasional parthenogenesis has been observed among the butterflies. Normal parthenogenesis takes place, e. g., in the honey bee, whose drones are developed from unfertilized eggs. In Cladocera and Ostracoda an alternation of parthogenetic and fertilized eggs occurs. Heteroparthenogenesis is found among the Aphides, where two distinct female individuals exist. Those with wings are parthenogenetic; those without wings reproduce sexually. Paedo-parthenogenesis occurs wherever parthenogenesis and paedogenesis (larval sexual maturity) concur as observed in the larvæ of Cecidomyia; also certain developmental phenomena of Distomea may be explained on the same basis. The cause for parthenogenesis is largely to be explained on economic principles.

Reproduction by fission frequently among the lower Metazoa. The organism divides into two parts of similar size, in each of which the necessary organs are 
developed by regeneration. The power of regeneration is the ability to replace lost members of the body. The lower the differentiation of an organism the stronger the tendency for regeneration. Trembley's investigations of last century show the extraordinary power of regeneration of the fresh-water Hydra. We may cut a Turbellarian or Annulate worm into two parts, and each one will grow into a complete animal again. Similar regenerations occur among the Crustacea and Echinodermata; even the Vertebrates exhibit such phenomena, e. g., in the growth of the severed extremities of Triton and lizard, and in the replacement of finger-nails and the healing of wounds.

The cells along the cut surface give up a part of their differentiation, grow very rapidly and furnish material for new limbs, but always rebuild the old germ layer to which they originally belonged. The division may be artificial; we tear a starfish into two parts and regeneration follows. In the genus Nais regeneration precedes division, even to the partial formation of new organs. Regeneration zones arise whenever a new individual begins to appear; division takes place as soon the new forms are able to perform the necessary functions, each one developing a new zone before separation, so that sometimes temporary cormi arise. This constitutes an incomplete division resembling budding. The process of division only occurs where there is no sexual maturity. Embryonic division, with premature regeneration, takes place when the adult animal is too complicated to permit division. We find this phenomenon even in man in the development of twins, which may result either from the fertilization of two eggs or from the division of an early embryonic stage. Incomplete division causes monstrosities. 
A number of other phenomena, not yet fully investigated, belong under the head of fission.

Reproduction by budding occurs when only a limited part of the adult body develops into a new individual. Primordial budding takes place especially among the Cnidaria and the Sponges. An evagination of the body wall arises (anywhere), grows in length and assumes the form of a young Hydra, with tentacles and mouth opening. It sometimes separates from the mother and becomes an independent individual; when it remains cormi arise, which may branch out like trees. Often the budding individuals differ from the sexual individuals, being merely persisting larvæ. Continued embryonic budding occurs in more highly complicated organisms and only in certain predisposed places. It begins in the embryo when a primary bud arises, from which all later buddings are developed. Otherwise it proceeds like primordial budding. This phenomena has been observed among the Endoprocta, Ectoprocta and many Tunicata. Both regeneration and budding may be due to similar causes.

It has been stated before that the various modes of asexual reproduction occur only as secondary modifications together with sexual reproduction (often in the larval stages of an animal), in such a way that the former regularly alternate with the latter. An alternation of generation takes plaçe whenever two generations with entirely different modes of reproduction and of entirely different organization follow each other. Even the phenomena of heterogeny might be classified under this definition.
Alternation of generation is therefore based upon:
(a) Heterogeny (e. g., Rhabdonema nigrovenosa).
(b) Parthenogenesis (e. g., Aphides, Distomea).
(c) Fission (e. g., Scyphomedusæ). 


\section{(d) Budding (e. g., Hydromedusæ).}

The most peculiar combinations arise during these changes. The individuals of a cormus may perform the same functions (homomorphous), or each one may perform a distinct function (polymorphous). The cormus of the Siphonophora consists (according to Leuckart) of locomotory individuals, nourishing individuals, reproducing individuals, etc., thus resembling only organs of one and the same individual.

The considerations of the phenomena of reproduction may justify a few remarks on the theory of heredity, by which the causal relation is to be explained which exists between the morphological phenomena of one generation and those of a following one. Its aim is to interpret not only the repetition of typical characteristics, but especially the appearance of new ones, and the various ways in which they are transmitted to successive generations. The-first problem has been explained by the theories of differentiation (which deals with the changes of the reproductive cells) and of fertilization (which deals with the mixing of characters by the union of two individuals).

The theory of differentiation explains both the development of the organism from the egg, and the reappearance of reproductive cells in the new organism. Caspar Friedrich Wolff first elucidated the process of differentiation in the egg of the chick (theory of epigenesis, I759). In modern times three prominent scientists claim to have found the true interpretation of the problem: Darwin, in his pangenesis, Nägeli in his theory of idioplasm, and Weissmann in his theory of the continuity of the germ plasm.

Darwin assumes that minute germ particles of all the 
cells, constituting the various tissues are carried to the generative organs and deposited in the reproductive cells, so that all the qualities of the body exist there, as we might say, side by side. During development they are again distributed to the corresponding parts of the new body. It is difficult to show how that process is carried out.

Nägeli assumes the existence of a more or less complicated plasma structure, the idioplasm, which extends as a connected network through all the cells of the body. It consists of a very large number of elementary particles, micelle, which posses all the qualities of the individual. The manifold differentiations of the various parts of the body are caused by the action of certain definite rows of similar micellæ whilst the others are at rest, so that potentially all the cells of the body possess the same qualities, but only a few of them manifest themselves at a time. Thus all the qualities of the body are present also in the egg cell.

Weissmann maintains that it is a definite part of the cell which causes differentiation, namely the nucleus. He applies the name idioplasm to the nuclear substance (chromatin), but defines it in a different way. Nuclei are separate formations with separate distinct qualities. In the nucleus of the reproductive cell, however, are all the qualities of the various nuclei present, side by side. During development these qualities are distributed to the various cells of the new body. The karyoplasm of the reproductive cell (W.'s germ plasm) possesses, therefore, the most complicated structure, whilst that of the other cells represents the simplest structure. Some of the cells receive the original nuclear substance and are deposited as reproductive cells in the new body (conti- 
nuity of germ plasm). The different kinds of karyoplasmatic formations are consequently autogenetically the same, resembling Nägeli's idioplasm.

Hatschek holds, chiefly on the basis of the phenomena of regeneration, that not a distribution, but an actual change of qualities occurs which is due to the infinite possibilities of variation characteristic of the chemism of organic combinations. He explains the origin of the reproductive cells from the fact that in every organism virtually undifferentiated cells are deposited to furnish the reproductive cells (continuity of virtual germ cells).

The theory of fertilization has established the fact that conjugation is not a mere influence of the spermatozoon over the ovum, but an actual continued existence of its organization in the fertilized ovum and its products, which implies the transmission of the characteristics of both parents, each furnishing one half. This diminishes in successive generations. Phenomena of atavism, the barrenness of bastards, grafting of hybrids, etc., are of importance.

The transmission of individual characteristics may be (according to Darwin) either direct, affecting a part or the whole of an organism immediately, or indirect, affecting the reproductire cells only and manifesting themselves in the following generation. Darwin explains the process according to his theory of pangenesis and Nägeli according to that of idioplasm. Weissmann, on the other hand, maintains that acquired or direct changes of the body are not transmissable, only those which affect the germ cells. He explains this on the basis of his theory of the continuity of the germ plasm. A transmission of injuries has never been proved; diseases are transmitted, from generation to generation, by infection. Special 
talents manifest in many generations may be traced back to the first ancestor of the family. Weissmann also shows that the assumption of direct transmission is not necessary for the explanation of phylogenetic changes. As a consequence of the continuity of the germ plasm it is but natural to suppose that all phenomena which effect the body effect in some indefinite way the reproductive cells, producing in them latent changes, which manifest themselves in the following generation. A change in the constitution of the reproductive cell conditions a change in the constitution of every body cell, $i$. e., of the entire body. 


\section{CHIEF CLASSIFICATION OF THE METAZOA.}

\section{Zoöphyta or Colenterata.}

III. Plathelminthes.

IV. Vermes.

V. Arthropoda.

VI. Mollusca.

VII. Echinodermata.

VIII. Tunicata.

IX. Vertebrata. 


\section{ZOÖPHYTA OR CEELENTERATA.}

The body consists of two layers, ectoderm and entoderm. An intermediate layer is either absent, or, whenever it is present, it shows intimate relations to ectoderm and entoderm. The digestive track has only one external opening (mouth). A body cavity between intestine and cuticle, as well as blood vessels and excretory organs, are absent. A nervous system is either entirely absent or is but little centralized.

I CLAss. Gastræada* (showing essentially the structure of a gastrula). A. Physemaria. Tubular beings, consisting of two layers with one aperture, fastened to the bottom of the sea. Generative organs develop in entoderm; the entoderm contains foreign bodies. Haliphysema, Gastrophysema. A. Dicyemida (parasites in Cephalopoda, Echinodermata and Turbellaria). Ectoderm ciliated, forming a continuous layer around the solid entoderm, which consists of a single multi-nuclear axillary cell, no mouth opening, no digestive tract. Generative organs consisting only of ova-like germs which develop within the axillary cell apparently without fertilization. The unicellular germ divides into two unequal parts. The larger one (macromere) remains undivided and becomes the axillary cell; the smaller one

*E. van Beneden and Julin suggest the name Mesazoa for this class, making it an intermediate series between Protozoa and Metazoa; whilst Luckart, Metschnikoff and Whitman consider them to be retrograded Plathelminthes. 
(micromere) repeatedly divides and becomes the ectoderm. Dicyema. C. Orthonectida. Entoderm consists of a layer of cells; body externally segmented. A layer of muscular fibres between ectoderm and entoderm. Sexes separate. Spermatozoa and ova in entoderm. The micromeres develop the muscular fibres. The macromere forms the accumulation of cells. Rhopalura. Appendix. Trichoplax adharens, peculiar animal discovered in the marine aquarium at Gratz, consisting of three layers, and resembling a ciliated plate of irregular shape. It multiplies by fission.

\section{CLASS. Porifera or Sponges.}

I. Subclass: Calcaria. Skeleton always present consisting of calcareouss picules. Asconida (with simple canals): Olynthus. Grantia. Syconida (thick walls with straight radial tubes): Sycandra. Leuconida (thick walls with branched channels): Leucandra.

I. Order: Calcispongice.

2. Subclass: Non-Calcarea. Silicious skeleton. In structure they are Leuconidæ.

2. Order: Hexactinellidoe. (Glass sponges). Silex spicules either isolated or forming a hyaline lattice-work of six-rayed stars, resembling the radial tubes of the Syconidæ. Cemented together by a silicious substance. Mostly fossi1. Living: Euplectella (Philippines); Hyalonema (Japan).

3. Order: Spiculispongice (needle sponges). Skeleton consisting of independent, different silicious spicules; rarely absent. Cemented together in bundles by an organic substance or forming a massive, firm network. Never cemented together by a silicious substance. Geodia, Chondrosia, Oscarella and Halisarca (without skeleton). Tethya, Tuberella, Suberites. 
4. Order: Halichondrince. Skeleton consisting of uniaxal silicious needles cemented together by a horny substance (spongine). Halichondria, Reniera, Spongilla (fresh water), Myxilla, Clathiria.

5. Order: Ceraspongice (horny sponges). Skeleton consisting of horny fibres. No spicula of their own. Often grains of silex and sand are present as foreign bodies. Spongelia, Euspongia officinalis (common ioilette sponge), Aplysina.

All sponges with the exception of the Spongillidæ live in the sea. Their external form and structure is so variable that a general description is impossible. Their internal structure is represented by three types, the Asconida, Syconidae and Leuconida. The first type (e. g., Olynthus) consists of a thin-walled tube, attached at one end and open at the other. Its walls is perforated by pores, which may open or close whilst the water flows through them in the tube and out through the aperture or osculum. It consists of two layers: of an almost homogeneous external layer in which cells and calcareous needles are imbedded and an internal epithelium of collared cells resembling the protoplasmic collar of certain Flagellata. There may be a thin flat epithelium external to the layer containing the skeleton so that we would get three layers, an ectodermal, an entodermal and a mesodermal layer of connective tissue. In the second type (e. g., Sycandra) the walls have becom a thicker and radial tubes penetrate them from the central cavity so that the surface of the sponge shows numerous cone shaped elevations above these tubes. They are lined with a collar-epithelium, whilst the epithelium of the central or gastrula cavity seems to be changed into a pavement epithelium. The water penetrates the radial tubes, 
enters the gastric cavity and makes its exit through the osculum. The third type (Leucandra), representing the large majority of sponges, shows a still more complicated canal system. The collar-epithelium is confined to the so called flagellate clambers lying in the thick mesoderm. The pores open into branching canals covered with flat epithelium, which lead into the flagellate chambers (adductory canals). They in turn open into another set of branching canals (eductory canals), which lead into the central cavity and finally to the osculum.

The vibration of the flagella of the collar-epithelium keeps up a constant flow of water in the canal system of the sponges. A highly developed canal-system indicates a loose structure of the body, a highly, developed mesoderm always indicates a solid structure of the body.

The mesoderm of the sponges represents a kind of connective tissue consisting mostly of a gelatinous consistence in which variously shaped cells are imbedded. These often contain pigment or possess the power of motion (wandering cells), or contraction (closing the pores, muscular cells). The mesodermal tissue is the seat of the various skeleton formations (silicious, calcareous, horny). There may be one or more kinds of spicula in one individual, occurring either loose or connected into skeletons. The same is true of horny fibres. The common toilette sponge is simply the horny skeleton of the animal with the animal parts removed.

A nervous system has not yet been discovered (mesodermal ganglion cells?).

Reproduction is either sexual or asexual.

Asexual reproduction takes place by external or internal gemmation or budding.

External budding. Buds are formed at different parts 
of the body, which, by budding, may give rise to stocks or colonies. Pseudo-canals arise within the interspaces, which must be distinguished from the true canals. The number of oscula may correspond to the number of individuals constituting a stock.

Internal budding (?) Groups of cells (gemmula) separate from the body and develop, after an interval of rest. into sponges. (Spongilla.)

Sexual reproduction. The sponges are largely hermaphrodites or diceious; however, spermatozoa and ova are developed at different times; they are proteranderous hermaphrodites. These cells seem to be developed from mesodermal cells.

Development. Oscarella (Halisarca) lobularis manifests the following typical phenomena. After repeated divisions of the ovum a free swimming larva or blastula is produced, a spherical form consisting of a single layer of flagellate cells. Through invagination a gastrula arises which attaches itself at the blastopore, or mouthend, which gradually closes. Between ectoderm and entoderm a gelatinous substance is secreted into which cells migrate, probably from the ectoderm. Thus the mesoderm (connective tissue) arises. Radial evaginations of the entoderm develop from the cœlom, and grow into the mesoderm, becoming flagellate chambers. They connect with the surface, either by pores or by evaginations of the ectoderm. The osculum is formed at the aboral pole by the lengthening of the cœlom, which finally breaks through : Sycon stage.

The relation between the Porifera and the other Cœlenterata is only indirect, since the osculum does not correspond to the blastoporus of the gastrula, nor to the mouth of the Cœlenterata. 


\section{Class. Cnidaria.}

I. Subclass: Hydrozoa. Prototype Hydropolyp or Hydrula. Mouth leads directly into the entodermal canal. No gastric filaments. Genital products arise from the ectoderm. Sexes represented by different persons.

I. Order: Hydrida (fresh water polyps). Single persons or small cormi without periderm, consisting of a few persons of the same kind. Reproduction, sexual and asexual (budding). Hydræ develop directly from the egg. Hermaphrodites. Hydra, Microhydra in fresh water.

2. Order: Hydromedusce. Hydroid cormi, at least dimorphous, since beside the usual sterile nutritive persons sexual persons arise by budding, which separate either as craspedote free swimming medusæ or remain sessile as medusoid gonophores. In a number of Hydromedusæ the attached Hydroid form is suppressed, inasmuch as from the fertilized eggs of the craspedote medusæ, new medusæ are directly developed. . A natural classification of this order is an impossibility since the observations are still incomplete.

r. Suborder: Hydrocorallia. Colonies with calcareous peridermal skeleton. Genital products develop in the gonophores. Stylaster. Millepora. No corresponding medusæ.

2. Suborder: Tubularia. Naked or chitinous colonies. The chitinous periderm never widens into a cupshaped cell around the polyp head. In some forms the medusæ are reduced to sessile gonophores. The corresponding Anthomeduse are craspedote medusæ. Without marginal bulbous swellings and without otoliths; ocelli at the base of the tentacles. Gonads in the external wall of the digestive stalk; 4 , rarely 6 or 8 , radial canals. $\mathrm{E}^{*}$ 
The following examples represent the Hydroid form on the one side and the corresponding medusæ form on the other:

Syncoryne Sarsii.

Podocoryne carnea.

Eudendrion ramosum.

Bougainoillea ramosa.

Stauridium Cladonema.

Codylophora lacustris (fr. w.)

Tubularia larynx.

Unknown.
Sarsia tubulosa.

Dysmorphosa carnea.

Lizusa octocilia.

Margelis ramosa.

Cladonema radiatum.

Wanting.

Wanting.

Ctenaria clenophora.

3. Suborder: Campanaria. Hydroid colonies with chitinous periderm, enlarging around the polyp heads into Campanulæ into which the heads with the tentacles are withdrawn. Modified polyps, without tentacles and mouth (Gonangia) develop medusa buds or sessile goncphores, united in groups. The corresponding Leptomeduse are craspedote medusæ, partly with and partly without bulbous swellings along the edge, when present; they are developed from the velum insertion, with exodermal otolith cells. Ocelli, either absent or present, along the base of the tentacles. Gonads always along the radial canals. Number of radial canals variable.

Campanularia geniculata.

Unknown.

Unknown.

Campanulina termis.

Unknown.

Laomedea caliculata.

Canaliculata.
Obelia geniculata. Eucope campanulata. Gastroblasta Raffalii. Phialidium variabile. Equorea Forskalea.

Wanting.

Related to the Campanaria are the Plumularice and the Sertularice. They are branched Hydroid colonies. The nutritive polyps of the former are arranged in single rows; those of the latter in double rows, on opposite sides of the stem. The genital products are budlike processes (gono- 
phores) (with a chitinous periderm) which arise in groups, on specially modified polyps, without mouth and tentacles. Their nature is not fully understood.

4. Suborder: The Hydroid form is wanting. The corresponding Trachomeduse are craspedote medusæ with auditory vesicles which may either project freely on the marginal surface above the velum or be enclosed in a vesicle which lies in the gelatinous substance of the disc and close to the edge of the latter. Ocelli mostly wanting. Gonads always along the radial canals. Either 4 or 6 or 8 radial canals, between them often blind centripetal canals. Direct development with metamorphosis. Olindias Mülleri. Rhopalonema velatum. Aglantha digitalis. Geryonia proboscidalis. Carmarina hastata.

5. Suborder: Hydroid form wanting. The corresponding Narcomedusa are craspedote medusæ with auditory vesicles which always project freely on the marginal surface and contain entodermal otolith cells. Ocelli mostly wanting. The tentacles are inserted upon the exumbrella which is thus divided into a number of collar flaps. Gonads in the digestive stalk extending peripherally into the radial digestive pouches. Radial canals either wanting or present in the form of flat radial digestive pouches. Circular canal sometimes obliterated. Number of tentacles, flaps and pouches indefinite (4-32). Development direct with metamophosis. Cunina, Pegantha. Egineta. Aginopsis. Solmaris.

3. Order: Siphonophora. Polymorphous, free swimming Hydrozoan colonies, whose persons are modified craspedote medusæ adapted to special functions.

I. Suborder: Siphonanthe. The heteromorphous persons bud along a stalk of variable form, resembling the digestive stalk of a medusa. 
I. Family: Calyconecte without pneumatophore and tentacle with one or more swimming bells at the upper end of the stalk. The remaining heteromorphous persons arranged into groups (cormidia), which may detach themselves either as Eudoxia or Ersæa. Praya, Diphyes. Abyla. Hippopodius.

2. Family: Physonectce with pneumatophore, without aurophore, with several swimming bells and tentacles. Apolemia. Agalma. Anthemodes. Halistemma. Physophora. Forskalia.

3. Family: Auronecte with a large pneumatophore; beneath it a circle of swimming bells in whose dorsal median line a large (respiratory) air bell (aurophore) lies (a modified swimming bell). Stalk shortened and thickened. Without tentacle(?). Stephalia. Aurelia. Rhodalia.

4. Family: Cystonecte with a large pneumatophore without aurophore. Swimming bells and hydrophyllia (protections) wanting. Rhizophysa Physalia (very short stalk, disc-like, thickened).

2. Suborder: Disconantha. The heteromorphous persons are situated on the subumbrella of a disc which encloses a many chambered pneumatophore and resembles a medusoid umbrella. The margin of the disk carries a circle of numerous tentacles. In the middle of the subumbrella is the central nutritive stalk or chief sipho.

5. Family: Disconecta. Discalia. Porpita. Porpalia. Velella.

II Subclass: Scyphozoa. Prototype: the Scyphopolyp or the Scyphula. Always with ectodermal œsophagus. Gastric or mesenteric filaments are present everywhere along the septa. The genital products arise from the entoderm. The sexes are generally represented by different persons. 
I. Order: Anthozoa (corals). Separate sessile persons or colonies. Body essentially a Scyphula. The ectodermal œsophagus leads in form of a tube into the wide gastric cavity which is divided into a number of peripheral diverticula (radial pouches) separated by septa. The septa continue with their free internal margin towards the aboral part of the body.

I. Suborder .A. Octocorallia. Alcyonaria (or Actinozoa). Generally with 8 septa and 8 tufted tentacles. Polyp colonies of very varying form. Skeleton formation very different. Alcyonium, Permatula. Kophobelemnon. Gorgonia. Isis. Tubipora

B. Tetracorallia. 2. Suborder: Rugosa. Number of septa large, a multiple of 4 . With calcareous skeletons. Fossil paleozoic forms.

C. Hexacorallia. 3. Suborder: Antipatharia (horny corals). With 6 or 24 simple tentacles. Colonies with a horny auxiliary skeleton. Antipathes (6 tentacles, 2 developed septa), Gerardia (24 tentacles and septa.)

4. Suborder: Madreporaria (stony corals). Mostly colonies, rarely single, with strongly developed calcareous skeleton. 6n simple tentacles and septa in larger $\mathrm{num-}$ ber and variable arrangement. Madrepora. Astroides Fungia. Astraa. Mcandrina. Cladocora. Caryophyllia. Flabellum.

5. Suborder: Actinaria (fleshy corals.) Mostly single, with $6 \mathrm{n}$ tentacles and septa in large numbers, and different arrangement. Without skeleton. Cerianthus. Zoanthus. Actinia. Anemonia. Adamsia. Edwardsia.

II. Order: 'Scyphomedusce (Acraspedæ). Mostly free swimming single persons, bell or disc-shaped; the mesodermal supporting layer developed into an enormous gelatinous mass. The ectodermal œsophagus lies mostly 
within the digestive stalk, which is suspended from the centre of the subumbrella. The four radial pouches of the Scyphula are retrograded in the higher forms. The exumbral and subumbral walls of the gastric cavity fuse in such a way as to form only a system of radial gastrocanals of different structure. With tufts of gastric filaments Genuine velum wanting; instead marginal lobes with prolongation of the gastro vascular system.

A. Medusæ with highly arched umbrella; the 4 radial digestive pouches and their separating septs more or less distinctly preserved.

I. Suborder: Stauromedusa. 4 septa preserved ( $L u$ cernaria) or reduced to 4 knots (Tessera), 4 or 8 gonads in the subumbral wall of the 4 digestive pouches; without sensory vesicles. Lucernaria (sessile 8 marginal lobes, each carrying a tuft of tentacles). Tessera (free without distinct marginal lobes, with 8 tentacles).

2. Suborder: Peromedusa. 4 septa reduced to 4 knots, therefore the 4 pouches united into a circular sinus. 8 gonads at the subumbral wall of this sinus. With 4 interradial sensory vesicles. 8 or I 6 marginal lobes, 4 or I2 tentacles. Pericolpa. Perlphylla.

3. Suborder: Cubomedusce (Charybdeida). 4 septa preserved; 4 pairs of gonads on the septa, freely protruding into the digestive pouches. With 4 perradial sensory vesicles, containing an auditory vesicle with an entodermal otolith sac and carrying one or more eyes ; 4 interradial tentacles or tentacle tufts. Mostly with velarium. Charybdea, Chirodropus.

B. Medusæ with flat discoid umbrella. The four primary digestive pouches of the Scyphula retrograded through disappearance of the septa. Instead there are secondarily developed (as a remnant of the fusion of the 
exumbral and subumbral vascular-lamella) 8, i6, 32, or more broader or smaller, often anastomosing radial canals. The 4 interradial septa (remnant of the original septa) or tæniola carry the phacella or tufts of gastric filaments. Derelopment either directly with metamorphosis or with alternation of generations. In the latter case the gastrula develops into a sessile Scyphula which becomes a young sessile medusa (Scyphistoma). The Scyphistoma is capable of reproduction by fission or budding (strobilation). The constricted medusæ (Ephyra) change by metamorphosis into the adult form

4. Suborder: Discomedusa. I. Family: Cannostoma. With simple mouth tube, without oral arms, with square mouth and short solid tentacles. Nausithoë. 2. Family: Semostoma. With four large multi-lobed oral arms and cross-shaped mouth. With long, hollow tentacles. Pelagia noctiluca. Cyanea. Aurelia aurita. 3. Family: Rhizostoma. Mouth closed. With numerous suctorial mouths on the 8 long root like oral arms, without tentacles. Cassiopea. Pilema (Rhizostoma). Cotylorhiza. Crambessa. Cannorhiza.

IV Class. Ctenophora.

I. Order: Tentaculata. With two lateral tentacles which can be retracted into pouches. Gastro-vascular canals end blindly. I. Family: Cydippida. Body spherical or oval. Hormiphora. 2. Family: Lobata. Body laterally compressed with two oral lobes in the median plane.

Eucharis. 3. Family: Cestida. Body elongated to the form of a band in the direction of the sagittal plane; without oral lobes. Cestus.

2. Order : Nuda. Without tentacles. Mouth wide, œsophages very large; gastro-vascular canals strongly anastomosed. 4. Family: Beroida. Beroë. 
General Description. The Cnidaria are Metazoa with a persisting primary axis, and of radial structure; with epithelial muscle and nerve tissue, and with nematocysts (nettling cells or lasso-cells); their germ epithelia arise either from the extoderm or entoderm. Their ancestral type is polypoid (Archhydra of Haeckel).

We distinguish two fundamental forms of structure: the sessile polyp form and the free swimming medusa form. Some Cnidaria become sexually mature, as polyps, others later in their medusa condition; the transition takes place by means of an alternation of generation. Phylogenetically the sessile form is the earlier from which the medusa form has been derived by adaptation to the free swimming mode of life and by higher differentiation.

The body of the polyp has the form of a tube, grown fast to its support at its basal end (pole of attachment), whilst the other free end shows the mouth opening (oral pole). Near this end is a circle of mobile, very contractile tentacles, which thus divides the body into two regions, the oral disc and the aboral disc or the cup.

Two anatomically distinct types are known. I. The Hydropolyp or Hydrula. A primary mouth opening leads directly into the very simple primitive gastric cavity which continues only within the tentacles. The body wall consists of the ectodermal epithelium and the entodermal epithelium, which join at the mouth opening: between them lies a gelatinous layer, free from cells. The same layers are in the tentacles. 2. Scyphopolyp or Actinopolyp. A secondary mouth opening leads into an œsophagus, which is internally covered by the ectoderm (evagination of body wall); at the internal cesophageal opening, ectoderm and entoderm join. The primitive 
gastric cavity (the gastro-vascular cavity) is more complicated on account of its projecting longitudinal entodermal folds (septa), so that we distinguish in it a central stomach and peripheral gastric canals. In the œsophageal tube the septa are broader and mostly grown together with it, so that the gastric canals continue here as gastric pouchcs, reaching into the tentacular cavities. The septa are situated between every two tentacles. The body wall consists of three layers, the gelatinous layer, however, containing mesenchymal cells (connective tissue cells).

The body form of a medusa corresponds in a general way to that of an arched disc or bell. The convex aboral surface (cup of polyps) is uppermost, it has the name $e x$ umbrella. Around the margin of the disc is a circle of tentacles (homologous to that of polyps). The lower concave surface, called subumbrella, is homologous to the mouth disc of the polyp; it carries in its centre a stalklike process (digestive stalk, mouth stalk) at whose lower end the mouth is situated. The gelatinous layer has thickened into a powerful disc (umbrella) lying beneath the exumbrella. The gastro-vascular system is thus pressed closely to the surface of the subumbrella. In this connection it is generally so transformed that only its central part remains a cavity (central stomach), whilst its peripheral part forms a system of canals, mostly radial canals and a marginal ring canal into which the tentacular canals open.

The exumbrella is covered with a simple pavement epithelium. The margin of the disc does not only bear the tentacles, but also the epithelial nervous system (double ring of ganglionic nerves in $\mathrm{Hydromedusæ,} \mathrm{a}$ number of ganglia in Scyphomedusæ) and the numerous 
sensory orzans (auditory organs, eyes), It also has in the Hydromedusæ a contractile marginal border or velum beneath the tentacles which narrows (like a diaphragm) the entrance to the bell cavity; in the Scyphomedusæ, however, it is prolonged into a number of marginal lobes. The subumbrella possesses a strong muscular epithelium by whose (and that of velum) contraction the water is rlythmically ejected from the bell cavity. The reaction propels the animal in the direction of the aboral pole; the elastic gelatinous disc acts as an antagonist to these muscles.

Two types of medusæare, therefore to be distinguished the Hydromedusæ and the Scyphomedusæ. However much similarity there is in the structure, a closer morphological investigation shows that they do not descend from one and the same type, but the one from the $\mathrm{Hy}$ dropolyps the other from the Scyphopolyps. The Cnidaria are therefore divided into two chief divisions, the Hydrozoa and the Scyphozoa each of which contains earlier polyp forms from which medusæ forms originated, The germ epithelia of the Hydrozoa are ectodermal, those of the Scyphozoa entodermal.

The histology of the Cnidaria has been indicated under the general head of the Metazoan histology.

The characteristic radial structure of the Cnidaria is based upon a repetition of like organs around the chief axis. The intercalation of new radii, which may be either regular or irregular, is the law of growth governing the multiplication of the radii.

Reproduction and development. The sexes of the Cnidaria are, with a few exceptions, separate. The genital products are in most cases simply emptied into the water, The eggs are generally very small and very 
numerous. Segmentation is equal. Gastrulation occurs either by polar invasion or by invagination or by epibolism. The typical larva of the Cnidaria is the so-called planula, a long, oval, ciliated form consisting of an exterdal ectoderm epithelium, and an internal compact entodermal mass, without protostoma and cœlom. In this condition the larvæ does not take any nourishment, and is capable of rapid locomotion. The planula fastens itself with the apical pole, and changes into a polyp, which represents either the final form (Actinozoa) or produces by fission or budding medusæ (Hydromedusæ, Scyphomedusæ). In some cases medusæ arise directly from the planula (Haplomorpha, Pelagia). Reproduction by (primordial) budding or fission, is very general, and may take place in the planula stage, but most frequently in the polypoid stage. A bud arises by an evagination of all the layers of the body wall, forming either polyps or medusæ; medusæ, however, only produce medusæ by budding. The new individuals may either detach themselves from the parent skin (Hydra, medusæ) or form cormi (Polyps, Siphonophora). Fission takes place either longitudinally, and is as such complete or incomplete (cormis), or transversely (strobila), and is as such always complete.

General description of Ctenophora. The Ctenophora are Metazoa with a persisting primary axis, and a modified radial structure. They possess an ectodermal œsophagus and a partly radial gastro-vascular apparatus, an apical sensory (nerve) plate, eight meridional rows of ciliated plates, in most cases a pair of tentacles and highly developed muscular and connective tissues They are hermaphrodites.

The Ctenophores are gelatinous, slightly colored, 
transparent animals, provided with two long tentacles and swimming freely in the ocean; their general size varies between one centimeter and several decimeters. They resemble the medusæ in form and habit, differing, however, very markedly by their peculiar mode of locomotion which is carried on by eight meridional rows of conspicuous comb-shaped organs. The shape of a simple Ctenophore is that of an egg or pear, with the oral pole generally on the upper surface; the opposite region is termed apical, or aboral or sensory pole. The structure of the body is quadriradial (each radius being forked), each radial plane containg two unequally differentiated interradei which are either medial, corresponding to the direction of the mouth slit, or transverse, lying in the direction of the tentacles. This radiation is conditioned by the position of the organs which may therefore be divided into radial (4 times repeated) and adradial (8 fold), medial (2 fold) and transverse (2 fold). Stereometrically the body can be divided into two symmetrical halves, each one representing a symmetrical body.

The external body epithelium is rich in pigment cells, irisated cells and glandular cells. Its differentiations are the contractile, richly pigmented tentacles, further eight rows of ciliated plates which proceed in four pairs towards the apical pole. The sensory plate lies in a considerable depression, an ectodermal thickening consisting of high narrow cells and probably representing the central nervous system. It is directly connected with the different sensory organs; from its surface radially arranged compound sensory hairs arise carrying otoliths (auditory organ); four pigment masses probably represent eyes and two ciliated polar fields joining the 
sensory plate in a median direction are generally considered to be organs of smell.

The mouth opening is a split lengthened in a median direction; from it an ectodermal strongly ciliated œsophagus procedes leading into the transverse central stomach (infundibulum) of the gastro-vascular apparatus, from which the following peripheral canals radiate: 4 radial canals which fork and thus form 8 adradial meridional vesicles; two transverse cesophageal vessels disappearing near the mouth; two transverse tentacylar vessels ending within the base of the tentacles; the infundibular canal, an axial continuation of the infundibulum opening near the sensory plate.

The mesodermal gelatinous substance contains connective tissue cells, mesenchymal muscle fibres and probably nerve fibres.

The gonads are situated along the meridional vessels, ovaria along the one side and testes along the other; they are ejected through the gastro-vascular apparatus. (See Chun's monograph on Eucharis).

Their reproduction is exclusively sexual. Development is direct. The egg is small, but rich in yolk (centrally situated). Segmentation is unequal. The gastrula is formed by a process which is both epibolic and embolic. At the blind end of the entodermal sac a cell plate is formed, which represents the unique structure of the mesoderm. (Metschnikoff). The œsophagus arises by evagination of an ectodermal tube on the vegetative pole: the protostome (as œsophageal opening) is thus lowered. Four gastric pouches arise in the direction of the primary radii. In the surface eight groups of ciliated plates appear; then the sensory plate at the apical pole, with the characteristic auditory apparatus, finally the tentacles remarkably near the apical pole. 
There are no other homologies between the three higher classes of the Cœlenterata than those which are the result of the common derivation from the gastræa, common to all Metazoa. 


\section{PLATHELMINTHES.}

I CLASS: Turbellaria. Independent Plathelminthes with ciliated body-epithelium, living mostly on the bottom and under stones in ocean and rivers.

I. Order: Polycladidea (pelagic forms). Large Turbellaria with flat, leaf-like body, with numerous ovaria and testes, without yolk glands, mostly with two separate external sexual apertures. The alimentary canal sends out numerous branches which anastomose.

I. Tribe: Cotylea. Ventral proboscis furnished with papillæ. Mouth and pharynx central or anterior. Tentacles wanting or present on the anterior margin of the body. Anonymus. Thysanozoon. Yungia. Cycloporus. Stylostomum. Eurylepta. Prosthiostomum.

2. Tribe: Acotylea. Without proboscis. Mouth and pharynx central or posterior. Tentacles wanting, or two present on the anterior dorsal region. Planocera. Leptoplana. Trigonoporus. Cestoplana.

.2. Order: Tricladidea (pelagic, fresh water and terres: trial). Body flat and of considerable length. Mouth and protrusible pharynx posteriorly. With a common external sexual aperture with two germ stocks and numerous testes and yolk glands. The alimentary canal consists of an anterior, unpaired and two lateral posterior branches, which lead into side branches. Planaria. Dendrocœlum (fresh water). Geodesmus. Bipalium (terrestrial). Gunda segmentata (pelagic).

3. Order: Rhabdocolidea. In fresh water and marine. 
Small forms. Alimentary canal, when distinctly visible, a cylindrical, straight, blind sac, either without any or with very few distinct lateral branches.

I. Tribe: Alloiocela. Alimentary canal distinctly separate from the parenchyma, frequently with short, lateral diverticula. Numerous testicular vesicles. Female germ glands either two ovaria or two germ yolk glands, or separate germ and yolk glands. Monotus. Plagiostoma. Vorticeros.

2. Tribe: Rhabdocola. Alimentary canal sharply separated from the parenchyma, without lateral diverticula. Frequently large interstices arise in the parenchyma filled with a liquid substance and forming a kind of body cavity. Two large testes. Female germ glands, one or two ovaria or one or two germ stocks and yolk glands, or two germ yolk stocks. Vortex. Graffilla (parasitic). Macrorhynchus. Mesostoma. Prorhynchus. Microstoma and Stenostoma (both with separate sexes). Macrostoma:

3. Tribe: Accela. Without distinct alimentary canal; with digestive parenchyma. Without excretory organs; with numerous very small testicular vesicles and two ovaria. Nadina. Convoluta.

II Class: Trematoda (Flukes). Parasitic unségmented. Plathelminthes without cilia, mostly with forked alimentary canal. Mouth and pharynx at the anterior end of the body; two testes, one germ stock and two branching or numerously lobed yolk stocks.

I. Order: Eetoparasitica (monogenetic Flukes). With at least three suckers. Development direct, without alternation of generation; life history simple, without heterogeny. Tristomum. Diplozoon (two young immature animals early unite crosswise and in this condition become mature). Polystomum. Gyrodactylus. 
2. Order: Entoparasitica (digenetic Flukes). With two suckers at most. Life history with heterogeny. Distoma hepaticum, lanceolatum, both in the gall ducts of the sheep's liver. Distoma isostomum. Gynæcophorus hæmatobius, in the blood of Africans, both with separate sexes; the male with a groove, the canalis gynæcophorus, on the ventral side for the reception of the female. Amphistomum Monostomum. The Sporocyst and Rediæ generally live in water snails; the sexual generation mostly in the alimentary canal of the Vertebrates.

III CLASS: Cestoda (tapeworms). Entoparasitic Plathelminthes. without cilia and without alimentary canal, with numerous testicular vesicles, two germ stocks and one or two lobed yolk stocks. Organs for attachment at the anterior extremity.

I. Order: Monozoa. Unsegmented single persons. Amphilina. Caryophyllæus. Archigetes.

2. Order: Polyzoa. Colonies of Cestoda arising by strobilation: segemented tapeworms. With scolex and proglottides. Phyllobothrium. Tetrarhynchus. Ligula (indistinct external segnientation). Bothriocephalus latus: broad tapeworm in the alimentary canal of man. Over 3,000 proglottides With two sucking pits at the head. Sexual apertures in the middle of the ventral surface of the segment, one behind the other. Larva ciliated, aquatic. It becomes a Scolex, with six hooks, and lives in the flesh of the pike, the eel-pout, and perhaps of other fish. Schistocephalus. Triæphorus. Tænia; with four suckers. T. saginata (mediocanellata) without hooks at the rostellum, with over I, ooo proglottides, sexual apertures marginal; in the alimentary canal of man. The Cysticercoid lives in the muscles of cattle. T. solium; armed tapeworm of man, with double circle 
of hooks at the rostellum; sexual apertures marginal. About 800 proglottides. Cysticercus cellulosæ in the flesh of swine. T. serrata in the intestine of the dog. Cysticercus pisiformis in the liver of rabbit and hare. $T$. crassicollis in the intestine of cats. Cysticercus fascio. laris in the liver of mice. T. cucumerina in the intestine of the dog; its cysticercoid scolex in the body of the doglouse. T. cœnurus in the intestine of the dog. Its corresponding cysticercoid Cœnurus cerebralis in the brain and spinal cord of the sheep. $T$. echinococcus in the small intestine of the dog. Echinococcus veterinorum in the liver of man and different domesticated hoofed animals.

Gcneral Description. - The Plathelminthes (or Platodes) are Scolecida (see below), without an anus; their body is dorso-ventrally flattened; their highly developed mesenchyma produces the muscular cutaneous envelope: the dorso-ventral muscles and the muscles of the intestine, as well as the parenchymous connective tissue. which entirely or partly fills the primary body cavity; they possess a much-branched protonephridium (water vascular system); they are mostly hermaphrodites witl complicated sexual organs. Of the three classes the Turbellaria represent the ancestral group; from them the Tremadota are derived, and from them again the Cestoda.

The epithelium of the Turbellaria is a well developed vibratile epithelium, whilst that of the adult Tremadota and Cestoda, forming cuticular excretions, are hardly noticeable; subepithelial unicellular glands are generally present. The characteristic muscular cutaneous envelope of the Plathelminthes consists of an external continuous circular layer of muscles, of an internal layer of longitudinal muscles, arrayed in bundles and of an innermost network 
of diagonal muscle fibres. The dorso-ventral muscles, between the inner organs, anastomose at their ends. The parenchymous connective tissue, being largely vesicular (sometimes branched free cells), fills almost the entire primary body cavity, but often more or less conspicuous interstices remain as remnants of the primary body cavity. We also find various muscles of the alimentary system. The nervous system consists of the cerebral ganglia and the peripheral nerves, and is in all parts imbedded in the parenchyma and in the muscular layers. The cerebral ganglion is not far removed from the point of origin (the anterior or vertex pole); it is mostly two-lobed or entirely separated in two parts, which are connected by a transverse commissure (Trematoda). Numerous anterior nerves continue towards the anterior termination of the body, whilst the paired longitudinal nerves extend posteriorly, the ventral pair being the strongest and most constant; the dorsal pair and the two lateral nerves are less frequent (Polycladidea, Acœla, Tremadota). An œsophageal nervous system is present in the Dendrocœla. The peripheral nerves are often connected by commissures (transverse commissure of the posterior ventral region; even a network occurs beneath the cutaneous muscular envelope. Ganglionic cells are mostly present in the cerebral ganglion; sometimes in the peripheral nerves. The Turbellaria have two, four or more pairs of eyes at the anterior end of the body; also an unpaired auditory vesicle, ciliated pits and tentacles in the same region. Among the ectoparasitic Trematoda and the larvæ of the entoparasitic Tremadota occur cerebral eyes and organs of touch. To the Cestodes can only be ascribed a somewhat intensified sensitiveness of certain parts of the integment. Special sense-organs wanting. The aliment- 
ary canal of the Plathelminthes consists of the osophagus and the stomach (intestine). The mouth performs also the functions of rectum and anus, which are wanting. The Cestoda feed endosmotically, so that the alimentary canal is degenerated; in the Acœla the digestive parenchyma performs the function of the gastric system. The œsophagus is generally divided into two parts, an anterior diverticulum and a posterior muscular pharynx, which can be protruded like a proboscis (Turbellaria), or serve as a sucking pump (Trematoda). Salivary glands are frequently imbedded in the muscular tissue of the pharynx. The stomach (intestine) shows the tendency to branch out (Dendrocoœla, Trematoda) and to anastomose. Only that of the Rhabdocoela is a straight, blind sac, lying above the œsophagus. Its epithelium is mostly ciliated. The apparatus of excretion, generally termed water-vascular system, is distinguished by its numerous branches, which increase with the size of the forms; the excretory capillaries are very numerous and the collecting canals are more or less branched, showing even anastomosis. Various modifications in arrangement and external opening occur already among the Turbellaria. A pair of longitudinal trunks, opening externally near the posterior end, represent the original type; they may also open more anteriorly on the ventral side (Mesostoma), or even at the posterior end; a median union of the main trunks also occurs. Among the Dendrocola numerous openings of the two (or more) main trunks on the dorsal surface have been observed. The excretory organs of the monogenetic Trematoda (Polystomum) generally open separately on the dorsal side, whilst the paired main excretory trunks of the digenetic Trematoda (Distoma) open into a posterior, unpaired urinary bladder. Among 
the Cestoda an increase of the main trunks is the rule; numerous secondary openings occur together with the main opening.

The Plathelminthes are, with few exceptions (Microstoma, Distoma hæmatobium) hermaphrodites. Both sexual organs open in most cases into a common aperture on the ventral surface back of the mouth. The male apparatus consists of the paired testes and Vasa deferentia, a ductus ejaculatorius, prostate gland and an protrusible penis. The female organ is more complicated since the egg which develops in it is of compound character. The egg cell is derived from the (paired or unpaired) ovarium or germ stock, modifications of which develop into yolk stocks with numerous yolk cells, representing a secondary nutritive material or abortive eggs. The ovarian ducts and yolk passages lead into the external passage (first into the ootype); here the egg is fertilized, and together with a number of yolk cells enclosed by a chitinous secondary envelope which is secreted by special shell glands; the egg passage then terminates in the vagina, the organ of copulation. In most cases there is also present an uterus for the collection of the fertilized eggs and a receptaculum seminis, both being differentions of either oviduct or external egg passage or external sexual aperture.

The modifications of the complicated sexual apparatus are multifarious and form an important and interesting chapter in the comparative anatomy of the Plathelminthes. The fundamental type of both sexual organs is represented (I) by two pairs of longitudinal canals, the gonad passages which contain in form of peripheral diverticula the gonad (testes, ovaria) and (2) by the organs of copulation (penis, vagina). The former possess a 
mesodermal epithelium, the latter an ectodermal epithelium.

The eggs of the Plathelminthes are small, especially when a secondary nutritive material is present; segmentation is, therefore, equal, but the segmentation cavity is very small and gastrulation very probably epibolic (general among Scolecida). The whole animel has the general organization of a Plathelminth when it leaves the egg, but certain modifications occur. Only the larvæ of the pelagic Planaria possess in their peroral circle of cilia a larval organ which is probably palingenetic. The other Turbellaria, as well as the ectoparasitic Trematoda, undergo a direct development. The Distomæ possess a so-called infusorial larva, which has the essential organs of the Plathelminthes in rudimentary form. They are covered with large, ciliated cells (embryonic envelope) which afterwards disappear. Also the Cestoda possess an embryonic envelope, either forming a ciliated cell layer (Bothriocephalus) or a shell-like apparatus (Tænia). The larva itself is very small and rudimentary. Both Distomæ and Cestoda undergo a remarkable metamorphosis, whose individual stages must be looked upon as forms secondarily acquired. This series undergoes further complications through asexual reproductive processes. Reproduction by fission occurs among all the Plathelminthes, parthenogenesis among the Trematoda.

The distinction between the Colenterata and the Plathelminthes may be based upon the general structure of the body cavity. The former constitute the one great subdivision of Metazoa with only one alimentary body cavity, whilst the latter, with all the other Metazoa, constitute the Colomata, which possess a series of body cavities. The transition from the Ctenophora to the 
Turbellaria is represented by two forms: the Coloplana Mecznikowi and the Ctenoplana Kowalevskii. They are not yet bilaterally symmetrical. They resemble the Ctenophora inasmuch as they possess an aboral sensory organ, eight rows of ciliated plates, tufted tentacles, and the same general structure; they are related to the Polycladidia by their flattened body, capable of crawling, their general ciliation, their skeletal membrane, their muscular fibres, the general arrangement of their gastric canals, two dorsal tentacles and a dorsal nerve centre (?) and a water vascular system (?).

Hatschek includes the Plathelminthes (Platodes) un der his IV. phylum, the Zygoneura, containing the Scolecida, Articulata, Tentaculata and Mollusca, on the ground that they all possess a common ancestral larval form, the trochophora. The stage which ontogenetically precedes the trochophora is called the protrochula (no rectum). The Rotatoria always resemble the trochophora, whilst the Platodes only reach the protrochula stage (also called pilidium or scolex), whence they develop in a different direction from the other Zygoneura. This fact distinguishes them also from the other classes of the Scolecida. The Scolecida (see Hatschek's table) are Zygoneura with a primary body cavity, with mesenchymal muscles, with protonephridia and and with primary diverticular gonads. Their nervous system is mostly subepithelial. They are very small (often microscopic) animals of sluggish habit. 


\section{VERMES.}

The branch of Vermes does not form a very homogeneous or natural division of the animal kingdom. Its characteristics are, therefore, largely negative. A11 worms are bilaterally symmetrical animals of the most variable form. They surpass the preceding branches, inasmuch as they possess an anus and a blood-vascular system, which physiologically performs the functions of the gastro-vascular system. The absence of anus and blood system indicates secondary retrogression. The mouth opens on the ventral side of the anterior end of the body. A body cavity is either wanting or very variously developed. Beneath the external body epithelium there is in all shell-1ess forms a strong muscular layer (muscular cutaneous envelope). The nervous system is likewise of diversified structure. Only the presence of a nerve centre (brain, supra-cesophageal ganglion) above the œsophagus is constant. In most cases a nerve ring, encircling the œsophagus (cesophageal ring), occurs, from which longitudinal commissures proceed posteriorly, different in length, position and arrangement. A11 these parts, brain, œsophageal ring and longitudinal commissures belong to the central nervous system. Segmented body appendages (extremities) are wanting as well as a separate, muscular (ventrally situated) locomotory organ (foot). A strictly localized central organ of the blood system (heart) has only been observed among the Brachiopoda.

I CLASS : Nemertini (Rhynchocœla). Body ciliated, 
externally unsegmented, of elongated form, Gorso-ventrally flattened. Without a distinct body cavity, alimentary canal straight, mostly with lateral diverticula, anus at the posterior end of the body. Above the alimentary canal lies a separate protrusible proboscis, generally before and above the mouth. The central nervous system consists of a brain lying between proboscis and œsophagus and of two lateral commissures. Blood-vascular and excretory systems present. Sexes separate. Through regular repetition of internal organs (lateral digestive diverticula, circular commissures of the longitudinal nerves, sexual glands) a kind of internal segmentation (pseudometamerism) frequently arises. Almost exclusive pelagic.

I. Order: Palconemertini. Head without deep latera1 longitudinal furrows. Proboscis without stylets. Mouth back of the brain. Carinella. Polia.

2. Order: Schizonemertini. On either side of the head a deep, longitudinal split. Proboscis without stylets. Mouth back of the brain. Lineus. Borlasia. Cerebratulus. Langia.

3. Order: Hoplonemertini. Head without lateral furrows. Proboscis with one or more stylets. Mouth mostly before the brain. Amphiporus. Drepanophorus. Tetrastomma. Nemertes.

4. Order: Malacobdellini. Head without lateral furrows. Proboscis without stylets. A sucking disk at the posterior end of the body. Malacobdella, parasitic in sea mussels.

II ClAss: Nemathelmia (round worms). Body tubular, spindle or thread-like, unsegmented, covered with a thick cuticula. Body cavity generally spacious. Alimentary canal straight or wanting. Anus at the pos$\mathrm{F}^{*}$ 
zerior end. No blood-vascular or excretory system resembling those of other worms. Sexes generally separate. Nervous system; an œsophageal ring, a medio-dorsal and medio-ventral longitudinal commissure. Internal metamerism wanting. Only the circular commissures of the longitudinal nerves repeat themselves pretty regularly among the Nematodes. Mostly parasitic.

I. Order: Nematodes. With alimentary canal, without proboscis. Family Enoplida without pharynx, frequently with eyes, live free in the ocean, more rarely in fresh waters or on land. Family: Anguillulida. Small animals (either parasitic or free) with double pharynx, without eyes. Tylenchus scandens (in wheat). Anguillula aceti in paste, vinegar, etc. Rhabditis nigrovenosa. In damp, muddy ground. Sexes separate. The females are viviparous, but produce only very few (4 at most) larvæ which enter the lungs of frogs and toads and develop there into mature but hermaphroditic animals (Ascaris nigrovenosa), out of whose fertilized eggs the free living Rhabditis generation arises. Their life history is characterized by a kind of heterogeny. Spharularia bombi. The Rhabditis larval form lives in the earth. The fertilized females enter the females of the bumble bee, in whose body cavity or alimentary canal they become parasites. The pregnant uterus evaginates from the genital opening (like a hernial protrusion) and becomes a large tube, on which the body of the worm forms only a small insignificant appendage. Mermithida. Without anus. Larvæ parasitic in the body cavity of insects, emigrate into damp ground, where they become mature and reproduce themselves. Mermis nigrescens. Filariide. Filaria medinensis. Medina worm, 5-2 $\mathrm{mm}$. thick, I meter long, in the tropical regions of the old 
world. In the subcutaneous connective tissue of man. Larvæ in small crabs (Cyclopidæ). Trichotrachelida. Trichocephalus dispar, whipworm, posterior part of body swollen. In the human colon. Trichina spiralis. Mature as so-called intestinal Trichina in the small intestine of man, and of many mammals; it is viviparous, female about $3 \mathrm{~mm}$. long, male half as long. The young bore into the intestinal wall, and from here they penetrate (through the body cavity and the blood vessels) the muscle fibres, where they encyst themselves in a calcareous cyst or capsule. Man receives them through infected pork. The chief carriers of the Trichina are the rats.

Strongylida. Dochmius (Anchylostoma) duodenalis, with a strong, mouth capsule, armed with teeth. Female $2 \mathrm{~cm}$., male half as long. In the small intestine of man (Egypt, Brazil, India, Switzerland, Italy, Belgium). Especially frequent among miners, producing miners' anæmia. Eustrongylus gigas. Female $30-100 \mathrm{~cm}$. long. In the kidney of the dog and other mammals. Ascarida. Ascaris lumbricoides (spool worm). Male $25 \mathrm{~cm}$., female $40 \mathrm{~cm}$. long. In the small intestine of man. Oxyuris vermicularis. Female $\mathrm{I} \mathrm{cm}$., male half as long. In the large intestine of children.

The Gordiida occupy an isolated position among the Nematodes on account of their peculiar internal organizations. Mouth of adult closed, alimentary canal degenerated Gordius aquaticus. Mature form in fresh water. The embryos enter the larvæ of insects where they encyst themselves. If their host is eaten by another insect they continue their development in the new host and when almost mature enter the water. $30-90 \mathrm{~cm}$. long, I cm. thick. 
2. Order: Acanthocephali. Mouth and alimentary canal wanting. At the posterior extremity a protrusible proboscis with hooks. Only parasites. Echinorhynchus gigas. In the small intestine of swine. Larva in grubs.

III Class: Annulata. Body long and tubular, or dorso-ventrally more or less flattened. Soft epidermis or hard and tough, chitinous cuticula. Metamerism or segmentation of the body, conspicuous both in the internal organs and (mostly) also externally. Body cavity well developed (except in Hirudinea and Myzostomea). Blood-vascular system well developed, rarely entirely reduced. Alimentary canal is mostly straight from the mouth to the terminal anus. The nervous system consists of brain, œsophageal ring, and a segmented ventral ganglion chain. The system of excretion (wanting in the Myzostomea) consists of segmentally-arranged, paired nephridia. Frequently the nephridia perform the function of emitting the genital products.

I. Order: Hirudinei-Discophori (leeches). Body externally ringed; a certain number of external rings correspond to an internal segment. Around the mouth a sucker, beneath the arms a ventral sucker. Skin soft, setæ wanting. Alimentary canal mostly with paired lateral diverticula. Body cavity reduced, communicating with the well developed blood-vascular system. Numerous, segmentally arranged pairs of nephridia (loop canals), not used as sexual apertures. Hermaphrodites. Testes in several, segmentally arranged pairs, with special ducts, opening in one external sexual aperture. One pair of ovaria, situated before the testes; female opening behind the male, both in the anterior part of the body. Parasites or robbers; in fresh water, in the ocean and on land. 
I. Suborder. Rhynchobdellida (leeches with proboscis) Protrusible pharaynx cylindrical, lying free in the pharyngeal pouch. Clepsine. Pontobdella. Branchellion (with gill-like appendages upon the back.). The two last ones in the ocean upon Selachii.

2. Suborder: Gnathobdellide. Pharynx a muscular thickening of the œsophageal wall, projecting towards the lumen in form of three plates or septa, sometimes toothed. Hirudo medicinalis, the common leech. Hamopis. Aulastomum, horseleech. Nephelis. Several Hirudines are terrestrial. All the other members of this suborder live in fresh water.

2. Order: Chcetopoda (worms with setæ). An external segmentation mostly corresponds to an internal segmentation. I special segmentally arranged glandular sacs of the external skin free bristles (setæ) arise, protruding above the skin. Body cavity well developed and separate from the blood-vascular system. The genital products develop in special districts of the entothelium of the body cavity; they enter early the body cavity and are emitted through modified nephridia (vasa deferentia, oviducts, genital tubes, segmental organs).

The following division is purely artificial:

I. Suborder: Oligochata. With but few setæ, which are never disposed on special parapodia. Tentacles, cirri, or branchiæ wanting. Hermaphrodites. Direct development. In fresh water and terrestrial. Family: Aphanoneura. Acolosoma. Family: Naidomorpha. Nais. Dero. Stylaria. Family: Chatogastrida. Chatogaster. Family: Discodrilide. Posterior termination modified into a sucker. Parasitic in crabs. Branchiobdella. Family: Enchytraide. Pachydrilus. Enchytrcus. Anachata. Family: Tulificide. Tubifex. Psammoryctes. Clitellio. Limme- 
drilus. Family: Phreoryctide. Phreoryctes. Family: Lumbriculus. Rhynchelmis. Stylodrilus. Family: Criodrilida. Criodrilus. Family: Lumbricida. Allurus. Dendrobana. Allolobophora. Lumbricus (earthworm). Joining these Urochata, Endrilus, Acanthodrilus, Perichata, Pleurochata, Moniligaster.

A doubtful position within the Chætopoda occupy the so-called Archiamelida (Polygordius, Protodrilus, Ctenodrilus, Histriobdella) and Saccocirrus, forms whose organization is distinguished by its simple, embryonic character.

Between the Oligochæta and the Polychæta are the families of the Capitellida (Capitellus, Notomastus, Dasybranchus) and the Opheliacece (Ophelia, Travisia, Polyophthalmus.) Blood vessels are wanting in the former. The parapodia of both are much reduced. Gills present or wanting. Head not distinctly marked.

3. Suborder: Polychata. Setæ embedded in highly developed, segmentally arranged pads or humps or parapodia. Tentacles and tentacular cirri on the head; cirri, branchiæ (gills) and other appendages along the abdominal segments, attached to the parapodia. Sexes separate in most cases. Development with metamorposis. Marine forms.

A. Sedentaria Capitibranchiata. Tubular worms. Pharynx (proboscis) generally not protrusible, without jaws. Eyes wanting or small, but numerous on the head. Parapodia not well deveioped, the upper ones usually carry hair like setæ; the lower ones transverse ridges with hooked setæ or plates. Branchial (gills) mostly confined to the anterior segments or to the head. They dwell in tubes secreted or built up by the animal. Family: Carratulida. Cirratulus. Family: Arenicolida. 
Arenicola. Family: Spionida. Family: Spio. Family: Ariciada. Aricia. Family: Chloramida. Siphonostoma. Family: Terebellida. Lanice (Terebella). Polymnia. Amphitrite. Family: Serpulide. Serpula. Sabella. Spirographis. Myxicola. Protula. Family: Hermel: lide. Sabellaria. Family: Stermaspida. Sternaspis.

B. Errantia $=$ Dorsobranchiata (predaceous worms). Pharynx protusible ; generally with jarws; head distinct, mostly with few, but large eyes. Parapodia well developed. Branchiæ generally on the dorsal parapodia. Freeswimming or crawling animals, some of which live in tubes made by themselves. Family: Aphrodita, Aphrodite, Hermioce, Polyna. Family: Amphinomida, Amphinome, Euphrosyne, Notopygos. Family: Eunicida, Diopatra, Eunice, Halla. Family: Nereida, Nereis, Nephthys. Family: Clyceride, Glycera. Family: Syllide, Haplosyllis, Syllis, Exogone, Autolytus, Myrianida. Family: Hestonida, Hesione. Family: Phyllodocida, Phyllodoce. Family: Alciopidce, Alciope, Asterope. Family: Tomopterida, Tomopteris.

3. Sub-order: Echiurida. Body tubular; adult form unsegmented or indistinctly "segmented; without parapodia, cirri, and branchiæ. Anteriorly on the ventral side two setæ with hooks. Two anal glands (excretory organs) open into the terminal part of the much-twisted alimentary canal. Either two or three pair of nephridia or one nephridium. Anterior end of the body above the mouth lengthened into a long movable head lobe of various forms, with a ventral furrow. With a bloodvascular system. Sexes separate. Development with metamorphosis. Pelagic animals with a hidden mode of life. Echiurus. Thalascema. 
Bonellia. The very minute, turbellarian-like, ciliated males of this genus live as parasites in the females.

3. Order: Myzostomida. Body flat, disc-shaped, externally unsegmented. Margin of the body with cirri or short wart-like protuberances. Upon the ventral side five pairs of parapodia with hooks and supporting setæ in two longitudinal rows. Four pairs of laterally-placed suckers on the ventral surface. Pharynx the same as that of the Rhynchobdellidæ. Alimentary canal with lateral branches. Body cavity reduced. Organs of circulation, excretion and respiration wanting. The nervous system consists of the œsophageal ring and of a ventral cord united into a mass of ganglia. Brain reduced. Hermaphrodites. The oviducts open together with the alimentary canal in a cloaca. The seminal ducts open in two separate apertures on the ventral side. Hermaphrodites, but in certain genera there exist small males besides (complemental males). Parasitic upon Crinoidea. Myzostoma.

IV CLASS: Prosopygii. Body naked or within shells, of very varying form. Around the mouth a circle of ciliated tentacles or tufts which are often inserted upon a common horseshoe-shaped tentacle carrier (lophophore), which itself may be extended on either side like arms. Without parapodia and frequently without setæ. Anus almost in every case moved towards the anterior part of the body. The alimentary canal extends posteriorly and forms a loop turning again towards the anterior end. Body not at all or very indistinctly segmented. Blood-vascular system wanting or differently developed. Number of nephridia reduced (two pairs at the most). They sometimes serve as conductor of the genital products, and open anteriorly not far from the 
anus. Sexes separate. Only Phoronis is hermaphroditic. Pelagic; only few forms in fresh water.

I. Order: Sipunculacea. Body lengthened, tubular naked. The anterior mostly extenuated part of the body may be invaginated by special retractors as a proboscis into the larger and longer posterior trunk. Body cavity very spacious. Blood-vascular system (?) much reduced or wanting. The central nervous system consists of brain, œsophageal ring and median ventral longitudinal commissure. Segmentation is perhaps indicated by a regular repetition of nerve rings. Marine; live in the mud or in concealment.

I. Suborder: Sipunculida. Anus dorsal, situated anteriorly between proboscis and trunk. Mouth surrounded by tentacles. Generally two typical nephridia, opening near the anus, also serving as eductory passages of the genital products. The vascular system consists largely of two tentacular vessels accompanying the anterior alimentary canal. Sipunculus. Phascolosoma.

2. Suborder: Priapulidee. Anus dorsal at the posterior end. No tentacles around the mouth. No bloodvascular system. No nephridia. Two anal glands opening in the immediate neighborhood of the anus and perform when young the functions of excretory organs, later those of sexual organs. Priapulus. At the posterior end a tuft of appendages, serving probably as' gills. Halicryptus without tail appendage.

2. Order: Phoronidea. Body worm like, in a fastened chitinous tube. Numerous tentacles surround the mouth upon a horse shoe-shaped base. Anus dorsal, right next to the mouth. Around the mouth a nervous ring (œsophageal ring). Two nephridia opening anteriorly, serving at the same time as ducts of the genital organs. 
A simple blood-vascular system present. Hermaphrodites. Single germs: Phoronis.

3. Order: Bryozoa. Small animals. Anus dorsal, near the mouth. A brain ganglion between mouth and anus. Nephridia when present, in one pair, embryonic in type, opening near the mouth, not serving as genital organs. Numerous tentacles, upon a horseshoe-shaped base. They form mostly by budding sessile colonies of variable forms.

I. Suborder: Pterobranchia. Lophophores lengthened dorsally and posteriorly into a long, arm-shaped process, which carries two longitudinal rows of little tentacles. Alimentary canal confined to the anterior part of the body, lengthened posteriorly after the manner of a stalk. Body cavity little developed. Forming colonies, in tubes, which arise creeping upon a common stem. Rhabdopleura. Related: Cephalodiscus.

2. Suborder: Ectoprocta. Anus opening outside of the lophophore. Lophophore not drawn out. Anterior body naked, posterior part within a shell. Without stalk. Anterior part enclosed in a fold of the posterior in such a way that it is wrapped in a special sheath (tentacle sheath), from which it can be protruded. Body cavity rather spacious. Shell often encrusted with calcareous matter. Forming colonies. A. Phylactolcmata. Lopho. phore horseshoe shaped. In fresh water. Cristatella. Alcyonella. Fredericella. Lophopus. Plumatella. B. Gymnolamata. Lophophores circular. Pelagic, with the exception of Paludicella, Cellepora, Eschara, Bugula, Flustra, Alcyonidium, Hornera, etc.

3. Suborder: Entoprocta. Anus opening within the lophophore. A tentacular sheath wanting. Body stalked. With one pair of nephridia, Body cavity reduced, Pedi- 
cellini forming colonies. Loxosoma single individuals. Pelagic.

4. Order: Brachiopoda. The dorsal and ventral body wall forms two large (anterior) reduplications, so that the body is enveloped by a dorsal and ventral mantle lobe, which may unite posteriorly and laterally. The mantle lobes secrete a dorsal and ventral shell valve, which is mostly calcareous, but may be horny. The ventral one is generally more arched. At the sides of the mouth are inserted two long, buccal arms, covered with fine threads and rolled up spirally, often supported by a special calcareous skeleton of the ventral valve and lying within the mantle cavity, which is enclosed by the mantle lobes. Anus wanting or to the right of the mouth (only in Crania in the dorsal middle line of the posterior end). The central nervous system consists of an œsophageal ring with poorly developed brain and lower ganglia. One (rarely two) pair of nephridia, which serve also as ducts of the genital products opening into the mantle cavity to the right and the left of the mouth. Bloodvascular system probably present with a heart above the alimentary canal. The posterior end of the body frequently lengthens into a sessile stalk, which protrudes either between the shell valves (Lingula) or through a hole in a posterior elevation of the larger ventral valve. In many cases the stalk is wanting and the shell is fas. tened directly by the ventral valve. Exclusively pelagic. The large majority of genera and species fossil. The genus Lingula dates back to the palæozoic epoch.

I. Suborder: Testicardines. The valves are linked together (lock) by processes like a hinge. Anus wanting. Terebratula. Waldheimia. Thecidium (grown fast with the large valve). Argiope. Rhynchonella. Spirifer. 
2. Suborder: Ecardines. Without lock. Alimentary canal with anus. Crania. Lingula.

V CLASS: Rotatoria (wheel animalcules). Small, mostly microscopic animals. Internal segmentation wanting. At the anterior end a ciliated organ (wheel organ) of variable form. Posterior end lengthened into an appendage (food, stalk), frequently segmented. A vascular system is wanting. A pair of nephridia of embryonic structure, with several internal ciliated cells open with the anus and the oviduct into the cloaca. Sexes separate. Males small with degenerate alimentary canal. Mostly in fresh water. Animals living in sessile tubes or envelopes: Floscularia. Stephanoceros. Melicerta. Lacinularia. The ciliated organ is thrown out in lobes and tentacles. The living forms: Notommata. Hydatina. Brachionus (external coat) Asplancha. Parasitic upon Nebalia in the ocean : Seison.

The peculiar genus Dinophilus resembling certain annelid larvæ belongs in this category. Male and female resemble each other, or the female is smaller, without alimentary canal. The whole ventral side of the body is ciliated. Besides there are a number of successive ciliated rings on the body. A wheel organ is wanting. Nephridia in segmental arrangement of embryonic type. Appendix. II CLASS: Chaetognatha (arrow worms). Body cylindrical, longitudinal, with laterally placed horizontal fins. Head rather distinct. Body cavity spacious, divided by partition walls into three succession cavities, head cavity, body cavity, caudal cavity. Mouth surrounded by setæ (jaws). Alimentary canal straight, anus ventral, at the beginning of the tail. The central nervous system consists of the brain, the œsophageal commissures and a large ventral ganglion, No vascular 
system. Hermaphrodites. Ovaria in the body cavity, testes in the caudal cavity. Paired eductory passages (nephridia?) open at the right and the left of the tail. Pelagic. Sagetta. Spadella.

The small group of Gastrotricha may be placed near the Rotatoria, small animals with ciliated ventral surface, with longitudinal rows of bristles upon the back. Body ending in two lateral points. Alimentary canal straight, moutl followed by a muscular pharynx. Anus at the posterior end. Hermaphrodites. Nephridia insufficiently known. No blood system. Ichthydium. Mostly in fresh water. The Echinoderide (related to Nematoda) are minute marine animals, with ringed body, with setæ.

General. The phylogeny of the worms is still a matter of dispute. The Nemertini are, according to the latest investigations of McIntosh, Semper, Hubrecht, and Bürger, considered a separate natural class; the presence of a blood vascular system and an ants places them above the Plathelminthes. The systematic position of the Nemathelmia is very doubtful. It is probable that an acquired parasitic mode of life resulted in a degeneration. The Annulata constitute a rery large group extraordinarily variable in form. The segmented condition of the body seems to indicate the original type, whilst the Myzostomida, Echiuridæ, certain Chætopoda and, to a certain degree, also the Hirundinei may be retrograded forms. Some investigators maintain that the segmentation (metamerism) of the Annulata is a further development of the pseudo-metamerism of Turbellarian or Nemertian animals. Others look upon the Annulata as a colony, risen through axial budding. They place the Rotatoria next to the ancestral type, whilst others con- 
sider them to be simplified forms which mature in early developmental stages, thus remaining larval Annulata. The class of the Prosopygii consists of a number of distinct natural orders, whose organization would be easily understood, if we base it upon an adaptation to the sessile mode of living and upon a reaction of a shell or tube formation upon the body of more highly developed, segmented worms.

It may be necessary at this juncture, to say a few words on the structure of the Zygoneura larva Trochophora. Those characteristics which are present in the larvæ of different groups are to be considered as typical. The trochophora is bilaterally symmetrical, exhibiting an anterior and a posterior, ventral and a dorsal part. The mouth-opening is ventral, the anus posterior and somewhat dorsal. Its form is oval. The distribution of cilia on the surface is characteristic. On the vertex pole a tuft of strong cilia (apical ciliary head) appears. An equatorial or preoral circle of cilia or trochus divides the body surface into an interior half (vertex field and a posterior half (opposite field). This circle lies closely before the mouth and consists of two rows of thickened epithelial cells. Behind the month there lies a postoral circle or cingulum (one row). Between these two the adoral zone of delicate cilia, is situated with its motion toward the mouth; from the mouth to the opposite pole a furrow of cilia, with posterior movements, extends (ventral furrow of cilia). A preanal circle frequently occurs, but is of later development. The ectoderm, furnishing the external epithelium as well as that of the œsophagus and of the hindgut, represents the body cavity (with spacious blastocœlom) in which the two other germ layers are contained. The external epithelium secretes a 
distinct cuticula, consisting of supporting cells, ciliary cells, glandular cells and, as epithelial differentiations, the nervous system and the sensory organs, (primary cerebral ganglion, vertex eyes, one or two apical tentacles, ciliary pits, and in some Turbellaria an apical auditory vesicle). The main typical nerve cords proceeding from the cerebral ganglion are a pair of longitudinal ventral nerves, a pair of longitudinal dorsal nerves, a pair of cesophageal nerves branching from the ventral nerves and forming a buccal ganglion in the epithelium of the œsophagus. The alimentary canal has the shape of a horseshoe and consists of cesophagus (inward and forward, strongly ciliated, sometimes with chitinous appendage), midgut (entodermal shaped like a retort and divided into stomach with hepatic gland and small intestine) and hindgut (leading to anus). The mesodermal structures lie between body wall and alimentary canal and are either mesenchymons (in the blastocoelom) or epithelial (forming special cavities). Mesenchymous are the connective tissue cells and the unicellular muscles, consisting of a pair of longitudinal ventral muscles a pair of longitudinal dorsal muscles, a preoral circular muscle and a postoral circular muscle. Muscles of the alimentary canal are mostly small dilatators. The paired protonephridium is of mesodermal origin; it is a long tube fastened to the posterior part of the vental muscle and anteriorly closed by a terminal cell. The tube itself consists of perforated cells and opens externally before the anus. A colom sac with colom cavities is present at the posterior end.

Modifications of the trochophora depend upon the character of the metamorphosis of the animal. In the protochula or pilidium, the hindgut is not developed and the division of the midgut has not yet become distinct. 
It is very probable that both the protrochula and the trochophora exhibit repetitions of the characters of an original ancestral form. It is true the Trochosphora aquatorialis (a Rotatorian animal discovered by Semper upon the rice fields of the Philippine islands) resembled the trochophora very closely; it nevertheless can be said that it is also a typical Rotatoriagn, and not a larval form. Hatschek, therefore, maintains that the protrochula is a repetition of the protochozoon, the ancestral type of all Zygoneura; but in any case the internal organization, (nervous system, alimentary canal, muscles, and protonephridia) of every single group is to be explained in its relation to the ontogenetic stage of the trochophora. This is easily done in the groups of the Turbellaria, Rotatoria, and Endoprocta; it is still a problem in that of the Nemathelminthes, whilst the structure of the Nemertini shows characteristics of the Aposcolecida or Cephalidii without, however, forming a transition. In the Aposcolecida new characteristics arise (peritoneal pouches, mesenteries, peritoneal gonads, metanephridia, blood-vascular system), whose ontogenetic origin is still a morphological problem.

The body of the Nemertini is elongated, sometimes extremely so, reaching a length of several meters, while it is only a few millimeters thick. In their external ciliation and soft consistency they resemble the Turbellaria. We distinguish the anterior part or head (characterized by the cerebral ganglion, the ciliated pits, the openings of mouth and proboscis), and the posterior part or trunk, in which certain organs (digestive diverticula, gonads, etc.) metamerically repeat themselves, although not always regularly and symmetrically.

The lamination of the body is different in the different 
orders. Palconemertini exhibit the primary condition. The external epithelium is the seat of the various pigmentations (supporting cells, glandular cells, sensory cells). Beneath it lies the dermal layer (connective substance). This is followed by the somatic muscular structure, consisting of an external circular, and an internal longitudinal layer, which is divided into septa by radial muscle fibres. The next, i. e., the parenchyma layer, connective substance with cell corpuscles, separates the preceding from an internal circular muscular layer, belonging to the alimentary canal, and therefore called splanchnic muscular layer. In the dorsal and ventral medium live the latter forms with the longitudinal muscular layer a kind of nutuscular dorsal and ventral mesentery. The splanchnic layer does not only enclose the epithelial tube of the digestive canal, but also the muscular sheath of the proboscis, within which the Rhynchocœlom and the proboscis are contained. The paired gonads lie in the parenchyma layer, the lateral blood-vessels, between the somatic and parenchyma layers, the dorsal vessel between alimentary canal and proboscis sheath. The central nervous system, terminating in the trunk in the form of lateral cords, lies always outside of the muscular layers.

The lamination of the Hoplonemertini is almost the same as that of the preceding order; however, the lateral nerve cords lie here, within the somatic muscular structure, and instead of the complete splanchnic muscular structure dorsoventral septal muscles arise between the gastric diverticula.

In the Schizonemertini a powerful external longitudinal muscular layer appears exteriorly and gradually into the so-called cutis (longit. muscles, connective tissue and 
subepithelial glands). The splanchnic layer is only represented by septal muscles and the lateral cords always lie outside of the circular muscular layer.

The protrusible proboscis, an invagination of the body wall, is a typical characteristic of the Nemertini. Whilst it is only short and little developed in the first and second order, in the third it reaches an enormous length and is divided into several regions, the first of which bears a number of styles, the second a poisonous gland and retractor muscles. Mouth and proboscis are one in Amphiporus, Malacobdella and Geonemertes.

The nervous system is highly developed and consists of the cerebral ganglion and the lateral cords, which run along the whole length of the body, often uniting beyond the anus. The cerebral ganglion consists of a pair of ventral ganglia, connected with the ventral cerebral commissure, and a pair of dorsal ganglia, connected by the dorsal commissure, both embracing the opening of the proboscis; a posterior lobe (or ganglion in the third order) stands in closer relation to the cerebral ciliary pits. The lateral cords are provided with ganglionic cells, the whole structure resembling the ventral cord of the Annulata. From the brain nerves are distributed to the sensory organs, the œsophagus, the proboscis and throughout the whole length of the dorsum (a large and a small one). Metameral circular nerves proceed from the lateral cords connecting with the dorsal nerves; frequently a nerve layer, between the somatic muscles, takes their place. Eyes of inverse type are present in the head in various numbers; also paired auditory vesicles (CErstedtia). The cerebral ciliary pits have the function of organs of smell; they are typical for the Nemertini, being in them more 
highly developed than in any other animal. Sensory papillæ are found, especially in the head.

The alimentary canal is straight and ciliated throughout its whole length. The mouth lies on the ventral side and leads into the simple œsophagus; the next part is the midgut (chylus), provided with lateral diverticula metamerically arranged. A short hindgut opens directly into the anus.

The blood-vascular system consists of an unpaired dorsal vessel and paired lateral vessels; often segmental transverse vessels and a vascular network of the head are present. The vessels are contractile. The blood contains large colored corpuscles. The apparatus of secretion consists of two lateral, short, ciliated canals in the region of the œsophagus, which open externally. Short, lateral branches of them are intimately connected with the lateral blood vessel.

The Nemertina are rarely hermaphrodites. The paired gonads lie laterally within the parenchyma layer, and are metamerically repeated, alternating with the digestive diverticula. Each possesses its own eductory canal, which opens dorso-laterally and develops after sexual. maturity is reached.

The small eggs (poor in yolk) are laid in large masses of spawn; some Nemertini are viviparous. The develop. ment occurs according to their different types: (I) Development through the Pilidium larva [original type], (Lineus, Nemertes). Equal segmentation. Blastula. Gastrula. Larva, morphologically corresponding to the protrochula, and termed pilidium, resembling a fencing mask. Tro pairs of thickened ectoderm plates arise before and behind the mouth, they invaginate and represent the structure of the body wall with a third median 
pair, which produces the ciliary pits. The connection between these embryonic plates and the body wall is called annion. The plates grow together, forming a boat-shaped structure which surrounds the pilidium alimentary canal, and closes above it. Thus the young Nemertinus arises in the interior of the amnion cavity. The" body wall invaginates anteriorly, and forms the proboscis; the cerebral ganglion develops from a constriction of the ectoderm. The old body wall of pilidium and amnion-envelope are cast off and the creeping Nemertinus is the result. The vertex plate disappears.

(2) The development according to Desor's type [derived type], (Lineus), takes place within the spawn before leaving the egg membrane; a distinct pilidium larva is not present, but even here the ectoderm separates into an external ciliary embryonic membrane and a number of embryonic discs, which invaginate and form the Nemertinus. (No amnion.)

(3) Direct development (modified type), takes place when the young Nemertinus arises from entire cell material. But even here the expulsion of an external ciliary layer of cells has been observed.

In all cases the young Nemertinus possesses only a very short abdomen, only later growths enlarge it considerably.

Hatschek assigns the Nemertini a middle position between the Scolecida and Aposcolecida preceding them by the Gastrotricha, Rotatoria, Entoprocta, and Nemathelminths.

The unsegmented body of the Nematodes is rounded, more or less elongated, and both ends are, as a rule, tapered off. The mouth opening lies at the anterior end, the anus mostly at the posterior or ventral side. Many 
Nematodes are almost microscopically small, others may become as large as a large earthworm. Ciliation is absent in the whole life history of the group. A powerful, chitinous, transparent cuticula (which is periodically shed) covers the whole body; it is often transversely ringed externally whilst the internal layer consists of diagonally intersected fibrous systems. Spines and hooks may also be present. The hypodermis or subcuti- . cula lies beneath the cuticula; it consists of fibrously granular tissue in which muclei are embedded. The two lateral lines of the body appear to be powerful thickenings of the subcuticula along which (at least anteriorly) the excretionary canals are situated. The so-called dorsal and ventral median lines, however, are narrow, septa-like, projecting (internally) thickenings of the subcuticula within which several nerve cylinders are located. Immediately beneath the subcuticula lies a muscular layer, the innermost stratum of the body wall, consisting of longitudinal muscles (two dorsal and two ventral) arranged in form of four similar muscle fields and extending along the interspaces of the four longitudinal lines throughout the whole body. The histology of the muscular structure is very remarkable, dividing the Nematodes into Meromyaria, Platymyaria, Polymyaria and Cœlomyaria, according to the number and arrangement of the muscle cells. The body wall encloses a distinct body cavity with alimentary canal and sexual organs. An undifferentiated connective substance without cells, but distinctly arranged, fills the space between body wall and entrails. A cross section of the body shows an external epidermis, an epithelial muscular layer and the alimentary layer. The alimentary canal (straight and elongated) is divided into œsophagus, mid- 
gut and hindgut (proctodæum). A mouth with lips leads into a buccal cavity lined with a firm dentary cuticula; lips and teeth form distinct systematic characteristics. The œsophagus consists of an external simple membrane [propria], thick muscular walls, a chitinous lining and a triangular lumen, and is frequently dilated behind into a muscular bulb (pharynx), the chitinous lining of which is sometimes raised into ridges or tooth-like prominences to which the radial muscles converge in the form of conical bundles. Instead of the bulbus a gland of large dimensions may arise. The chylus consists of basal membrane, epithelial layer and internal, perforated cuticula. The hindgut is formed by an internal cuticula, epithelial layer and external muscular layer. Several unicellular glands open near the ventral (rarely terminal) anus. The excretory canals lie close to the lateral lines in the anterior part of the body, changing into short transverse canals near the œsophageal ring and opening ventrally into one aperture. The central nervous system consists of a ring surrounding the œsophagus. Anteriorly it sends off six nerve trunks, two along the lateral lines, and four submedian, which supply the papillary sense organs around the mouth, and are connected with numerous ganglion cells behind the lips. Posteriorly four submedian nerves are sent off, but they can only be followed a certain distance, whilst a dorsal and a ventral nerve extends the whole length of the body, corresponding to the ventral and dorsal muscle spaces, and here and there connected by ring fibres. The large Ascarides possess even an anal ganglion, some- times a complete anal ring connected with posterior nerves and ganglion cells. The sensory organs are constituted by the oral and posterior papillæ of touch, an 
eve spot near the œsopliagus (only in free Nematodes) and bristles of touch. The sexes of the Nematodes are separate (only few exceptions and one case of heterogeny). The males are smaller than the females, their ventral posterior termination being bent and covered with papillæ of touch. The female organs are coiled canals, the blind end of each of which forms the ovarium, and the successive parts the oviduct and uterus, leading to a short vagina. The different parts of the unpaired male genital canal are the testes (amœboid spermatozoa) the vas deferens and the bladder; it opens ventrally in the hindgut (cloaca). Paired chitinous evaginable spicula, situated in special pouches on the dorsal side of the hindgut form the apparatus of copulation. The termination of the cloaca itself may be protrusible; a bursa copulatrix is sometimes present. Development is direct. The oval fertilized eggs, provided with a rich yolk membrane, accumulate in the uterus, either sparingly or in large numbers. Development begins either after the separation of the eggs or already in the uterus. Segmentation is equal, but without a segmentation cavity; gastrulation by epibolism, gastrula mouth corresponding to the ventral line; two primitive mesodermal cells separate and furnish two mesodermal streaks, which separate into the four muscle regions, the excretory canals and the genital structure, the latter represented by two embryonic cells, typical in young Nematodes. Stomodæum and Proctodæum arise as ectodermal invaginations. The embryo is then oval, lengthens and lies finally spirally coiled in the egg membrane. The young animal shows already the typical characteristics of the Nematodes. They are often supplied with special arrangements for their parasitic wanderings 
The habitat of the Nematodes is very curious. The free individuals live in decaying matter, mostly in the ocean. Parasitic forms change their host at different stages of their development.

The Gordiidoe occupy a somewhat isolated position. Lateral lines are wanting. A cerebral ganglion, œsophageal ring and ventral cord seem to be present. The paired genital sacs extend through the whole length of the body, and are so intimately grown together with the longitudinal layer of the muscles that they resemble the peristoneal sacs of the Colomata. The genital organs open in both sexes by special posterior apertures. The terminal part of the male is forked and supplied with papillæ.

The Acantocephali are Scolecida (?) of entoparasitic habit; the alimentary canal is wanting; without cilia in all stages of life; the elongated, round body carries anteriorly an invaginable proboscis provided with hooks, behind which a ganglion is located; the body cavity consists of a thin cuticula, a powerful subcuticula with a system of subcutaneous canals, an external circular and an internal, longitudinal, muscular layer. Päired, clubshaped cumulations of the body, wall (lemnisci) protrude anteriorly into the spacious body cavity; sexes separate, the complicated genital organs open at the posterior end, development with peculiar metamorphosis.

The phylogeny of this group is greatly disputed. The tender cuticula and thread-shaped spermatozoa are peculiarities which make their relation to the Nematodes very doubtful. Their peculiar organization has evidently been acquired by adaptation to parasitic habits; it may also be probably an account of their remarkable histological structure that they are derived from smaller 
forms and that parasitism resulted in a considerable increase in size.

Most of the Acanthocephali are only one or a few centimeters long; Echinochynchus gigas, however, may reach a length of $50 \mathrm{~cm}$. There is little difference between dorsal and ventral side. The chitinous recurved hooks of the proboscis with which they fasten themselves in the alimentary wall of their host, are derived together with the cuticula from the subcuticula. An internal retractory muscle and a sheath with lateral retractory muscles constitute the mechanism of the proboscis. The ganglion at the base of the sheath sends nerves to the genital organs and the lateral body wall. The Subcuticula consists of vertical fibres and numerous granules, and a vascular system of subcutaneous canals filled with a granular fluid. Both muscular layers are composed of immense muscular cells of remarkable structure interwoven by the general connective substance. The lemnisci are continuations of the subcuticula and of the same structure. They probably serve the purpose of transferring the food to the body cavity. The male and female sexual organs are structurally of similar type. They are imbedded in an axial ligament (mostly undifferentiated connective substance), which extends from the sheath of the proboscis to the posterior end of the body. The male apparatus consists anteriorly of a pair of testes (with the thread-shaped spermatoza), the vasa deferentia, ductus ejaculatorius (with prostata), penis and protrusible bursa copulatrix. The ovarium of the female apparatus separates into cell balls; isolated maturing ova float in the body cavity. The eductory apparatus begins with a funnel-shaped organ (uterus bell, composed of a few immense cells), whose anterior large opening re$\mathrm{G}^{*}$ 
ceives (swallows) masses of eggs. Premature eggs are ejected into the body cavity by posterior dorsal openings; the mature, spindle-shaped eggs are carried through posterior, narrow canals (egg passages) into the oviduct (uterus) and from there into the vagina. Development takes place in two periods, embryonic development and metamorphosis. The latter is connected with a typical change of hosts. The sexual animals live in the alimentary canal of certain vertebrates (fish). The eggs with the ripe embryo are thrown out with the excrements and eaten by Arthropoda, where the larva bores through the alimentary canal and enters the body cavity. After developing into the young adult it returns to the old host and becomes mature.

The Gastrotricha are Scolecida with paired ventral ciliary band; mostly with forked tail appendage; with terminal mouth opening and œesophagus (similar to Nematoda).

We mention this group here, because the latest investigations of Zelinka show that they constitute a special class of the Scolecida. The oral ciliary circles (of the Rotatoria) are wanting; the mouth-opening is terminal, and the vertex plate dorsal. But other characteristics of the Trochophora, wanting in the Rotatoria, are present here, e. g., the ventral ciliated band and the ciliary pits. Hatschek places them immediately after the Plathelminthes.

The Gastrotricha are fresh water animals of microscopic size. Their form is spindle-shaped, the ventral side being flattened. The body is covered with a firm cuticula, which undergoes scaly differentiations. The cerebral ganglion is intimately connected with the anterior epithelium and its sensory cells and is situated 
dorsally before the œsophagus; it sends out posteriorly two ventral longitudinal nerves. The muscular system is represented by paired lateral and ventral longitudinal muscles. The excretory organs consist on either side of a single coiled tube with vibratile terminal apparatus and open in the middle of the body. The straight alimentary canal lies in a distinct body cavity. The mouth opening (with a circle of bristles) leads into an œsophagus (with triangular lumen and radial muscles) which is followed by a midgut consisting of large cells. A short hindgut opens above the tail appendage. It is not established whether they are hermaphrodites or of separate sex, since the existence of male organs has not yet been proved. The ovarium (posterior and ventral) consists of an accumulation of small cells which grow into very large eggs with a tough, often prickly yolk membrane. They are laid before development begins. This is direct, the young possessing the characteristic organization.

The Rotatoria logically follow the Gastrotricha. In their whole organization they stand nearest the trochophora type, which of course, is more or less modified. Essentially new characters are the separation of the nervous system from the epithelium, the dilated masticatory pharynx and the cloaca.

It is usually possible to distinguish between an anterior region (with cilia) of the body, which can be invaginated into the middle region whose cuticula forms a more or less rigid armor (sometimes externally segmented). The tail-like movable ventral foot appendage (mostly with two rami into which glands open) may also be retracted into the armor.

The anus is situated on the dorsal side of the foot. 
In sessile Rotataria the foot becomes a long contractile stalk which changes the position of the anus; in some cases the foot is entirely wanting. The simplest form is the Trochosphæra æquatorialis whose wheel apparatus is not retractile and whose trochus extends along the equator of the spherical body. There are also remarkable complications of the body form arising through the development of external movable appendages of the middle region.

The form of the body is also modified by the various differentiations of the ciliary circles (wheel apparatus). The trochus has locomotory, the cingulum prehensile functions. They may be lobed or disappear altogether; they may either surround the whole vertex field (flat or concave), or they may be interrupted in the dorsal and ventral median line.

The body cavity consists of the external cuticula (more vigorous in the middle region) and of the hypodermis, consisting of thin flattened cells. The muscles of the body wall do not form a connected layer; most constant are a few unicellular longitudinal retractory muscles extending through the body. The spacious blastocœlom contains the entrails kept in position by connective tissue cells and muscular cells. Special cells of the hypodermis are more powerfully developed (ciliary, sensory, glandular cells). The alimentary canal (straight or horseshoe-shaped) shows characteristic complications. The month-opening leads into the foregut (stomodæum) which is divided into the ciliated buccal cavity and the masticatory pharynx with chitinous masticatory apparatus, consisting, in most cases, of a pair of external and a pair of internal maxillæ, important for classification. The midgut (entoder- 
mal) is divided into the membranous ciliated esophag us with the midgut glands or pancreas, the stomach composed of large, ciliated epithelial cells and the narrow, ciliated hindgut opening into the cloaca (not ciliated). The excretory apparatus (water vascular) is a typical protonephridium, consisting of glandular, longitudinal canals extending to the anterior region and forming lateral branclies. They open either by means of a contractile vesicle or directly into the cloaca, when the bladder is an independent appendage. The central nervous system consists of a cerebral ganglion, situated dorsally upon the œsophagus. Among the sensory organs the eye spots are most prominent, having mostly the shape of an X. Cuticular sensory organs, consisting of groups of sensory cells, provided with a tuft of sensory hairs are present on the vertex field (apical tentacles?) in the middle region (dorsal and ventral pair), and on the trochus. The peripheral nervous system consists of nerves of the anterior region (to the frontal tentacles and the cells of the ciliary circles) and of longitudinal nerves (dorsal and ventral pair to the tentacles or blending into one). From these the nerves of the muscles branch out.

The sexes are separate. The unpaired ovarium on the ventral side of the female alimentary canal contain beside the germ cells a mass of large nutritive cells. A short oviduct (uterus) opens into the cloaca. The males rarely appear and possess a rudimentary organization. Most Rotatoria reproduce themselves throughout the largest part of the year, parthenogenetically, by means of so called summer eggs (the smaller enveloping the males). The hard-shelled winter eggs are, perhaps, not always developed. Development mostly direct, either after the egg has been deposited or in the oviduct. Seg- 
mentation of the small eggs (poor in yolk) is equal or slightly unequal (of the oligomerous type); grastulation epibolic. Habits modified by adaptation. Hatschek divides them into Vagantia (free swimming or crawling) and Tubicola (sessile, mostly with gelatinous capsule).

Following Hatschek's interpretation of the Vermes, we think it best to introduce the Entoprocta at this juncture. They are classified by Lang as a suborder of the Bryozoa, because they produce buds, which either become free or-and this is of importance here-remain united as a corm or colony. There are also other peculiarities in their organization which ally them to the Bryozoa. The chief reason, however, why they ought to be separated is based upon their entirely different phylogenetic derivation. The larva of the Entoprocta possesses an equatorial circle of cilia, which may be compared with the trochus. The convex region of the body (vertex) possesses at the apical pole a structure surrounded by sensory hairs and further ventraily a retractile ciliated structure; one of the two might correspond to the vertex plate. The opposite ciliated region contains the opening of the mouth, of the anus, and of the simple protonephridium in typical position. The mouth opening leads into a horseshoe-shaped, ciliated, alimentary canal, consisting of the typical ectodermal œsophagus, the stomach with a so-called liver, intestine and ectodermal rectum. The body cavity is primary. The larva is able to invaginate the opposite region, which assumes the form of an atrium with ciliary circle. Thus the larval organization fully corresponds to that of the adult, excepting the ciliated circle, which in the latler consists of ciliated tentacles, and the stalk-like elongation of the vertex region, by which the adult is fast- 
ened. A vertex ganglion is wanting in the latfer; but one is present between mouth and anus, sending nerves to the tentacles and to a pair of organs of touch. The Entoprocta are hermaphrodites or of separate sex. The paired testes and ovaria above the stomach are sac-like gonads opening before the anus. Loxosoma forms buds on the external wall of the cup, which separate as free individuals. In Pedicellina and Urnatella they arise on the stolo at the base of the stalk successively and form a cormus.

Before entering upon a discussion of the Annulata it will be necessary to establish the connection between the Scolecida and the Aposcolecida or Cephalidia. In the development of the latter the primary or trochophora organs occur (Scolecida stage), but they are confined to an anterior region of the body, the prosoma. Some of these organs remain larval organs and retrograde (protonephridium or prosoma kidney). In a posterior region, the metasoma, a number of secondary organs are developed, mostly differentiations of the cœlum sacs. They are the peritoneal epithelium surrounding the cœlum cavity, the germepithelium of the gonads, the metanephridia, paired tubes connected at one end with the cœlum and opening externally at the other end. They serve not only as kidneys, but also as genital aucts. Their morphological origin has not yet been fully established. Epitheliogenous muscles, derived from the cœlum epithelium, are especially the longitudinal muscles of the body. The external muscular layers, probably derived from the primary muscles of the Scolecida, are mesenchymatous structures genetically connected with the cœlom sacs. The blood-vascular system-typical for the Cephalidiaappears originally as a closed system of tubes in which 
the blood is circulated by means of the contractions of the vessels. Its typical parts are a dorsal vessel (interior circulation) and a ventral vessel (posterior circulation) both connected by a network of visceral vessels and somatic transverse vessels. In the higher types the dorsal vessels are changed into a heart. The ventral nerve cord (absent in Phoronis and the Bryozoa) derived from the ectoderm, is a continuation of the ventral longitudinal nerves, which form [separated] in the prosoma the œsophageal commissures, but are in the metasoma more closely connected by transverse commissures, and thus form the ventral cord.

Whilst the prosoma originally forms the larger part of the body, later developments enlarge the metasoma to such a degree that it far excels the prosoma in size, and its cœlomatic organs extend secondarily into the latter, where a retrogression of the protonephridia and the primary longitudinal muscles has taken place (Annulata). In all Articulata (Hatschek) a multiplication of the metasoma takes place, a repetition in the long axis, introduced by a repetition of the cœlom sacs (primitive segments), and termed metamerism. Prosopygii and Mollusca are unsegmented. In every somite or metamere all the organs are repeated in the same order and arrangement, so that each one presents an anterior and a posterior end. The metameres arise successively by the continuous division of the undifferentiated terminal segment whose posterior portion finally remains as the unsegmented or rudimentary termination. The prosoma of the Articulata differs in many respects from the metameres. Their body is, therefore, divided into, (I) the prosoma with prostomium and metastomium; (2) the metasoma, consisting of a number of metameres, whose last segment mostly carries the 
periproct (anus). Homonomous metamerism (metameres all alike) occurs only in lowest forms; the division of labor requires a differentation (heteronomous metamerism), which may refer only to the internal organization or to the external, which latter is.commonly meant by the term heteronomy. Generally groups of metamers are modified in the same way and cause the formation of regions, as in the case of the Insecta, Crustacea and Myriopoda. The for mation of the head is very irregular in the Articulata. It occurs gradually through the modification of the first metameres. Only in Protodrilus and Polygardius all metameres are alike. The prosoma alone is distinct from the metameres. It, therefore, constitutes the primary head of the Articulata. In all the Annulata a similar condition is developed. In the Arthropoda for the first time a distinct head is developed, and may be designated as typical for the branch. The metameres of the head become organs of the mouth. The head of the Crustacea consists of the prosoma and four metameres; so also that of the Tracheata (?).

The metameres arise from the primitive structures of the simple undifferentiated metasoma by a more distinct separation of certain parts. These primitive structures are: (I) the external epithelium or ectoderm; (2) the paired cœlom sacs which may also be represented by solid mesodermal streaks; (3) the digestive epithelium or entoderm; and (4) the mesenchymous cells situated between these lamina. Division (most characteristic) appears in the mesodermal streaks or cœlom sacs which separate into a number of successive sacs or hollow plates (primitive segments); later the segmentation of the ectoderm begins with the development of its organs and segmented constrictions; the entodermal segmentation occurs 
last and is rathęr indistinct. In many Annulata the formation of metameres begins in the free swimming trochophora larva and is, in the lowest forms, continued even after the sexual organs have become mature. Growth takes place at the posterior end. The full number of segments may be present already in the embryonic development (Oligochæta, Hirudinei), or at the end of the larval stage or at the time of sexual maturity. In many Crustacea at least two segments arise already during the larval stage, the others in the course of metamorphosis. In the higher Crustacea metamorphosis is suppressed and the metameres are formed during embryonic life. The same is true of the Insecta where all the segments appear at the same time. The Chilognatha increase their segments after they have left the egg membrane.

Metamerism also occurs among the Vertebrates and the Echinodermata (in each of the five radii of the body). The former is genetically derived from the Articulata; the latter may probably be traced to a special developmental stage. The Prosopygii and Mollusca are very likely derived from polymetamerous forms, in which a reduction to one single metamere took place, capable of a much higher development.

The Annulata are characterized by their homonomous segmentation (without typical compound head). Many investigators consider the Annulata the phylogenetic starting-point for all the succeeding higher animals. On that account they are morphologically of supreme interest. Hatschek maintins that Protodrilus and Polygordius stand nearest the original ancestral form of the Annulata, and therefore classifies them as Archiannelides. From these simplest forms the genealogical scale leads up to 
the Chætopoda, highest among which the Rapacia (Errantia) rank. The Hirudinei and Pligochæta are a secondarily simplified and modified form, so likewise the Echiuridæ.

The Archiannelides are small Annelides (Annulata) of very primitive organization; with large, distinct metastomium; with perfect $\epsilon x t e r n a l$ and internal homonomy of the metameres; with long primary tentacles (spionidous); with epithelial nervous system; ventral cord unsegmented; without bristles, without cirri, without parapodia; development with larval metamorphosis.

The genus Protodrilus represents the ancestral type of the Annelides in its simplest form. The body is elongated and round, growing thinner towards the posterior end. Metamerism as given above. All segments possess gonads; they constantly multipy; the terminal segment contains the anus and two glandular pointed processes. A ventral ciliated furrow of locomotory function extends from mouth to anus. There are besides a great many circles of cilia (preoral, postoral and segmenta1). The epithelial layer of the body consists of an external cuticula and the epithelium, containing supporting cells, glandular cells, sensory cells and nervous tissue. The ventral cord is divided into two divisions, running along either side of the ciliated furrow. The cutaneous muscular envelope consists of the longitudinal muscular layer (two dorsal and two ventral regions), whose fibres are arranged like the leaves of a book, the nuclei lying along the inner edge. A circular muscular layer is wanting (simplification of original character). The somatopleura lines the body cavity, which is not only divided into a right and left half by a dorso ventral mesentery, but also into two chambers by transverse septa (composed of the transverse 
muscles and the peritoneal epithelium). The latter forms the germ epithelium on the side turned towards the chief chamber. The alimentary canal (splanchnopleura, mus. cular layer, epithelial layer), beginning with the mouth opening, consists of a short œsophagus, with glands and peculiar pharynx, and of the chylus, a straight, ciliated tube. The blood-vascular system is composed of a sinus surrounding the chylus and growing behind the œesophagus into a contractile, heartlike dorsal vessel, which forks anteriorly. The two branches pass on to the tentacles, œsophageal commissures and ventral line, where they unite. The segmental organs (excretory, retroperitoneal) are present in all metameres. They consist of the ciliary infundibulum (opening in the preceding segment), and the canal running along the lateral line and opening externally. The central nervous system is composed of the cerebral ganglion, the osophageal commissure and the ventral cord, unsegmented and paired. The sexual organs are hermaphroditic. Development with metamorphosis. The germs Polygordins differ in a few points. The body is not ciliated and without ventral furrow. Essophagus simple, with a posterior circle of papillæ. Ventral cord, a median and unsegmented epithelial thickening. Throughont the whole length of the body a contractile blood vessel appears, connected by arched and segmental cross vessels. Sexes separate. Dinophilus is, perhaps, a retrograded Annelide form, resembling Protodrilus. Segmental organs without infundibuliun; dissepiments, mesenteries and blood vessels wanting; ventral cord only little developed. Sexes separate.

The Chatopoda are characterized by cuticular bristles or setæ rarely absent. They are developed in follicles (from the external epithelium); each seta being secreted 
by one single cell, which breaks through the follicle and projects above the surface of the skin. The follicles are deep-seated and provided with special muscles and a peritoneal cover. They are of chitinous consistency and fibrous structure. The variety of their forms is important for classification. We distinguish (a) simple setæ, consisting of one piece (setæ lineares; uncini, curved like an S; paleæ (glittering): aciculæ or needles, within the parapodia); by compound setæ, derived from the less curved uncini, and consisting of two pieces, the stalk and movable appendage according to whose manifold form, many types are distinguished (lance-shaped, sickleshaped, broom-shaped setæ). Compound setæ are only found among the Errantia. Arrangement of setæ is definite; in some cases they are added like tufts to special appendages of the body (Polychæta), in others (Oligochætha) they are simply inserted in the skin.

The body of the Chætopoda is mostly elongated, wormshaped, transversely round or ventrally flattened, The segments and their appendages are most important for the shape of the body, especially the external appendages (I) of the segment; (2) of the prostomium, and (3) of the terminal segment.

The segmental appendages exhibit the most manifold modifications. They either consist of simple retractile foot stumps containing a bundle of chisel-shaped, hairlike setæ, and are as such called protopodia (in Saccocirrus), or the originally simple appendage divides above the basal portion into a dorsal and ventral branch, each one carrying setæ and a cirrus or tactile organ; to the dorsal region gills (branchiæ) of simple or complicated structure may be attached. Such appendages are called parapodia. They are either complete or incomplete 
(certain parts wanting). The basal portion may disappear when the branches become independent, forming bristly knobs and pads, either in two rows or in one. When the parapodia and their appendages are completely wanting (Oligochæta) the satæ are embedded in pits of the integument. Among the various modifications of the parapodia in different regions of the body the development of peristomial cirri is the most important. The parapodial cirri of the anterior body segment are, after the union of this segment with the prosoma; developed into tentacular structures. In some cases several of the anterior segments undergo such a change. The setæ are suppressed and the cirri more highly developed (Phyllodocidæ, Eunicidæ, Nereidæ.

The appendages of the prostomium consist of two primary tentacles and generally five (typical) cerebral cirri. The tentacles are typical in Protodrilus, Polygordius and Saccocirrus (supplied with blood vessels, sensory cells and very contractile); there are similar lasso-tentacles in Spiondæ (with longitudional furrow). In all others they are more or less reduced. The cerebral cirri consist of a dorsal and ventral pair terminating in a single apical cirrus. They are simply a continuation of the four longitudinal rows of cirri. But through a displacement of the prostomium these cirri have assumed a dorsal position. They are complete in most of the Errantia ; in others retrogression has taken place; in the Terebellidæ they are very numerous; whilst the absence of prostomial appendages is typical in the Oligochæta and Echiuridæ.

The appendages of the periproct are manifold and morphologically not yet fully explained. They appear in the form of anal prongs (in many Archiannelides), in 
addition to which a circle of pappillæ occur in some Polygordiidas, which again lead to anal cirri in Opheliacea and Spionidæ. In the Errantia only a small number of large anal cirri is present, representing the terminations of the longitudinal rows. In some groups only two (rarely one) appear, while others are altogether free from them.

The organization of the Chætopoda follows closely that of the Archiannelides, with rare but important modifications.

The external epithelium secretes a distinct cuticula (containing diagonally transverse fibrous structures) which is strongly developed in the Errantia. The epithelium itself (subcuticula, matrix) consists of supporting and of glandular cells opening externally by pores. Subepithelial glands are rare, but may become powerful (tubes of Sedentaria). Here also the parapodial glands may be mentioned. The nervous system exhibits all the transitions of lamination, from the perfectly epithelial lamination to complete separation. The former is the rule among the Polychæta, the latter belong to the Pligochæta. The typical parts of the central nervous system are: the cerebral ganglion, the cesophageal commissure and the ventral trunk. The cerebral ganglion, when epithelial, almost fills the prostomium (Polychrta); when separate, it lies above the œsophagus (Oligichæta). Hatschek maintains that it is composed of middle brain, tentacular ganglion and posterior ganglia. The peripheral nerves proceeding from the cerebral ganglion supply the anterior part of the body and its sensory organs, which partly join the ganglion immediately. The œsophageal commissure leading to the ventral trunk consists of nerve fibres and their 
enveloped tissues. The anterior parts of the ventral trunks sometimes extend to the mouth surrounding it. The ventral trunk extends through all metameres (except the termina1) and exhibits a distinct segmentation. Connected with it are the transverse commissures and peripheral nerves (three in each segment). When the two lateral cords of the ventral trunk are far apart and connected by long commisures they assume the shape of a rope ladder; when they are closely together they constitute the ventral ganglion chain. The epithelial or subepithelial peripheral nerves often extend to the dorsal line, where they unite into a ring. At the base of the parapodia a parapodial ganglion is inserted, which, with other peripheral ganglion cells, may form a nerve plexus. An cesophageal nervous system with ganglia and connected with the cerebral ganglion and œsophageal commissures is generally present. A sympathetic nervous ganglion structure for the midgut has only been investigated in the Hirudinei. Sensory organs are only developed in the Errantia. The integumental sensory organs are generally sensory buds scattered over the whole body (special case of Capitellidæ). Sensory buds in the œesophagus may be organs of taste. The paired ciliated pits (or pouches) connected with the posterior cerebral lobe are considered to be organs of smell (in Polychæta). Auditory vesicles are rare, mostly in the region of the œsophageal commissure. Simple vesicular eyes occur generally on the prostomium of the Polychæta, connected with the middle brain. Their number varies. In some Serpulidæ eyes occur on the numerous threads of the tentacular crown. Only fe w Oligachæta (Nais) possess eyes (rudimentary). The somatic muscular structure consists of the external circular layer, the internal longitudinal layer (a dorsal and 
ventral pair with peritoneal epithelium and sometimes a medioventral region), the transverse septal muscles (Polychæta) and the muscles of the setæ bundles, extending in a different direction to the body wall. Visceral muscles are not only in the alimentary canal but also in other internal organs; the muscles of the dissepimenta may also be mentioned here. The directions of the alimantary canal, foregut, midgut, and hindgut exhibit manifold differentiations. The foregut or œsophagus always extends through a number of the first anterior segments in which no gonads are developed. It frequently contains a protrusible pharynx, which in the Archannelides appears as an anterior ventral appendage, whilst in the other groups the œsophagus itself is protrusible. At its posterior end there may occur either soft papillæ (Nephthys) or chitinous teeth, so-called jaws (Glycera). The pharynx may also lie in form of a tubular structure in the œsophagus (Phyllodocidæ) provided with a chitinous•tooth (Syllidæ) or with two lateral jaws (Nereidæ). In the Eunicidæ the pharynx reaches its highest development, consisting of an anterior ventral appendage of the esophagus which is provided with a large number of upper jaws and one pair of small lower jaws. The Oligochæta have a short œsophagus without pharynx and armature. The midgut consists of the peritoneal layer, external, longitudinal, and internal circular layer, vascular layer and internal ciliated layer. Segmental dilatations give rise to large blind sacs (Aphroditeæ). The secondary ventral canal (Capitellidæ and Errantia) and typhlosolis (earth worm) as well as the differentiations of crop and gizzard (Oligochæta) may also be mentioned here. The hindgut lined by the ectodermal epithelium is of small dimension. The blood-vascular system of the 
Chætopoda shows the typical characteristics with more or less important modifications. The Capitellidæ and Glyceridæ have no blood vessels. Generally a closed system is present which contains a colored liquid mostly without blood corpuscles. The dorsal vessel and often also the somatic vasular arches are contractile. The blood flows generally from the ventral vessel through the somatic arches (containing the branchial vessels) to the dorsal vessel, which is either simple or paired, or if wanting replaced by an alimentary blood sinus. Gill hearts occur in the vascular arches of Eunice; in many Oligochæta some of these anterior arches are transformed into lateral secondary hearts. The smaller forms of Chætopoda possess only the typical blood vessels, whilst new vessels and vascular branches in gills and body wall appear in the larger forms. The body cavity is divided by the typical median longitudinal mesenteries, the segmental septa and the transverse septa in a number of more or less separated chambers. But the introduction of the œsophagus in the anterior segments has given rise to a retrogession of the dissepiments and medial mesenteries in this region. The dorsal mesentery and transverse septa are altogether wanting in the Oligochæta. The peritoneal epithelium with which the body cavity is lined shows peculiar differentiation (chlorogogous cells of Oligochæta). The fluid of the body cavity contains lymphatic, colored (resembling blood corpuscles), and excretory cells. The typical segmental organs are the excretory organs, whose infundibulum protrudes into the next anterior segment. In the Polychæta they are short and wide, mostly straight, occupying a retroperitoneal position outside of the body cavity. In the Oligochæta they are always looped and coiled and 
located within the body cavity. Their canal is often differentiated. Of the many modifications we mention the occurrence of sexual organs in one segment, each organ having several infundibula corresponding to the groups of setæ (exotic Lumbricidæ); in the same animals a network of ciliated canals is connected with the segmental canals. In the Capitellidæ the anterior segmental organs perform the function of genital ducts in the Terebellidæ, whose body cavity is divided into an anterior and posterior cavity by a single specially developed dissepiment; the organs of the posterior segments become eductory genital passages. Special complications arise in Lanice conchilega.

The genital organs of the Oligochæta consist of one or two (Lumbricidæ) pairs of testes and of one pair of ovaria, the former always situated before the latter. They generally occupy the space between the ninth and fourteenth segment. The sexual ducts are separated from the germ glands and show great structural resemblance to the nephridia with sexual function. The male apparatus consists of the testes early dissolving into the mother cells of the spermatoza; of the sperm sacs (except in Chætogastridæ), into which these mother cells are early received and become mature; and of the vasa deferentia (different numbers), each of which consists of a preseptal funnel and of a sperm duct, which perforates the septum and opens externally. In some Lumbriculidæ a sperm capsule arises between the sperm sacs so that they become mere appendages. The preseptal funnels lie in the same segments as the sperm sacs or capsule. The female apparatus consists of the two ovaria, the two oviducts (not present in lower forms) and the receptacula seminis (invaginations of the integument). The eggs 
either mature in the ovaria or the ovaria separate into groups of egg cells, only one of which develops into an egg. In some cases germ sacs intervene between the ovaria and the oviducts. The receptacula seminis are in no connection with the sexual apparatus. They open externally and receive the spermatozoa through the external opening.

The sexes of the Polychætæ are with few exceptions separate. The ovaria or testes arise during certain periods from the entothelium of the body cavity. The position of the germ glands changes in a remarkable degree. They now arise on the genital plates now on the dissepiments, now on the mesenteries, now as cumulations of the entothelial sheath of the ventral vessel, etc. The ovaria or testes repeat themselves in several segments; their form varies as much as their position. The eggs or spermatozoa mature swimming free in the body cavity and are expelled through genital ducts (nephridia).

The development of the Polychæta and Archiannelides is indirect (free swimming larvæ), that of the Oligochæta direct (without larvæ). A number of the former groups are viviparous the eggs developing within the body cavity or within an uterus which is in reality a modified segmental organ. Various arrangement for breeding are also developed. Some expel their spawn in large gelatinous masses, others deposit the eggs without any special protection. Segmentation is unequal, but may come near the equal type. In the latter case a coloblastula arises with thickened entoderm or an epibolic gastrula, in fact all transitions between the different types of segmentation occur. Eupomatus (Hatschek) offers a good illustration of embryonic development. The spherical egg divides into eight blastomeres of 
almost equal dimensions. The segmentation of the animal pole is much more rapid than that of the vegetative, consequently the blastomeres of the latter remain so much larger. A blastula results in which the cells of the three germ layers are already differentiated. The upper hemisphere (smaller cells) furnishes the ectoderm; the lower largely the entoderm, two of its cells (primitive mesoderm cells) early assuming a spherical form and developing the mesoderm. The position of the mesoderm cells corresponds to the anal termination of the larva. An equatorial circle of cilia (later preoral of the larva) arises, and later the ciliated tuft of the larval vertex appears. The entodermal part of the blastula invaginates. At the same time the primitive mesodermal cells move into the interior and afterwards divide. The two original cells are still distinguished from the newly produced cells by their larger size. Hatschek calls them the pole cells of the mesoderm; they lie at the end of the two new mesodermal streaks. In the further development of the larva the alimentary canal curves towards the anal side and unites later with the depression of the ectoderm which furnishes hindgut and anus. In the meantime the blastopore had considerably contracted, forming a split with a small opening through which the ectoderm entered the interior, forming the œsophagus. Then follows, as an enlargement, the stomach of the larva, and after this the small intestine and hindgut. Already during gastrulation the embryos had arisen from the bottom to the surface of the water, and external changes took place together with the internal. The trochophora stage is reached. To what has been said before on the trochophora we might add that here the so-called cephalic kid- 
ney, the paired excretory organ, arises from the mesodermal streaks, i. e., from a few cells situated near the pole cell, which elongate and become hollow, so that the cephalic kidney reaches from near the anus to the œsophagus. It consists of a ciliated canal, which may divide, and one or more funnel-shaped blind terminations. The eye spot of the Eupomatus larva is situated in a cell of the vertex region, asymmetrically on the right side. The two ectodermal vesicles represent sensory organs which arise symmetrically at the posterior part of the body from each ectodermal cell respectively. They have the character of otolith vesicles. A perianal circle of cilia is formed in Eupomatus, wanting in many other larvæ of this group. The larva is transformed into the adult worm by a gradual reduction of the anterior region. Polygordius may serve here as an illustration. Segmentation manifests itself, due to a remarkable change of the mesodermal streaks, which through cell division, have grown quite considerably. Each one divides into two cell layers, extending towards the ventral and dorsal line. Anterior segmentation takes place, and the two layers of the streak separate, a cavity arising in each segment. Thus primitive segments originate, whose external and internal wall become the somatic and splanchnic layer in every segment of the anus, and whose adjoining walls form the segmental limits (dissepiments) of the worm body. The primitive segments belonging to each segment unite in the median line of the ventral and dorsal surface and form a ventral and dorsal mesentery. Upon the vertex plate of the head region the two very small ciliated tentacles arise. The originally vesicular midgut has elongated with the body and become cylindrical. The posterior circle of cilia appears immẹ- 
diately before the anus. Gradually the cephalic region decreases. The change of the vertex plate and the contraction of the head wall conditions the change of the large cephalic sphere into the slender head of the worm. The vertex plate has assumed the shape of a cone; the eyes appear more distinct than in the larva. The productive segments of the trunk have in rreased in number and the segmentation of the body has become more distinct.

In the last stage of development the segmental constrictions of the alimentary canal make the segmentation still more definite. The head sphere and the ciliated apparatus have disappeared entirely in this stage, and the worm is complete in its main features ; it gives up the larval habit and adapts itself to the crawling locomotion.

The larvæ of the Annulata are of very various forms because segmentation begins at phylogenetically younger stages than the trochophora represents. They are distinguished according to the distribution of their cilia as atrochæ, monotrochæ, telotrochæ, mesotrochæ and polytrochæ, nototrochæ and gasterotrochæ. Amphitrochæ are those which consist of dorsal and ventral semicircles.

The development of the Oligichata is direct. The fertilized eggs are deposited in solid chitinous cocoons of various form and habit. The number of eggs contained in them (swimming in an albuminous mass) differs accordingly. Only some of them develop at the expense. of the others. Segmentation is always unequal; but eggs, poor in nutritive yolk, give rise to an invagination gastrula; where the opposite is the case, an epibolic gastrula develops. The rise of the mesoderm streak is represented by two blastomeres which enter the seg- 
mentation cavity generally before the formation of the two primary germ layers (but apparently in relation to them). The mesoderm streaks themselves arise when the two cells divide and the resulting smaller cells separate from them. They extend along the two sides of the embryo towards the mouth, gradually moving to the ventral surface until they occupy both sides of the median line. Thus the embryo has considerably increased in size, and represents essentially a cell sphere of two layers between which the mesoderm streak is ventrally inserted. The blastopore has become a definite mouth around which a lip-like thickening of the ectoderm arises. Contractile cells around the mouth cause through their swallowing motions the filling of the alimentary canal with albumen and a consequent enlargement of the embryo. The egg membrane bursts and the embryo swims in the albuminous mass of the cocoon. In this stage it resembles the free swimming larva of the Annelides especially when an oral ring of delicate cilia, or an adoral ciliated zone arises. In some cases even a cephalic kidney is present. All these facts seem to indicate that the embryos of the Oligochæta are retrograded larval forms. The transition of the larval embryo into the adult worm results from the further development of the mesoderm streaks, which anteriorly grow around the fore-gut and enlarge posteriorly from the ventral side to the dorsal, thus separating the ectoderm from the entoderm. Segmentation had begun already at an earlier period and with it the separation of somatic and splanchnic layer, finally the primitive segments arise posteriorly and envelope the entoderm sac dorsally which completes the chief external form of the worm. A later ectodermal depression at the posterior and gives rise to the anus. 
Some remarkable cases of sexual reproduction and of alternation occur in the Chætopoda, e. g., in Ctenodrilus, Protula, Nais, Antolyteus and Syllis.

The Echiuride constitute another suborder of the Chætopoda. The form and internal organization of the larvæ as well as the origin of the setæ justify this conclusion. The retrogression of segmentation in the adult animal and the setæ, as well as the enormous enlargement of the cephalic lobe or so-called proboscis gives them the character of modified forms. The segmentation of Bone1lia is unequal, producing an epibolic gastrula; that of Thalassema is equal, resulting in an invagination gastrula. The entoderm represents in both cases a solid mass with a differentiated cell layer and an internal yolk mass. The larva of Thalassema and Echiurus corresponds closely to the trochophora form; segmentation, however, disappears later, and of the fifteen primitive segments only the somatic and splanchnic layer remain. The larva of the Bonellia may be traced back to the trochophora, but it undergoes an important modification.

The eggs of Myzostoma (hermaphrodites; sexual apparatus resembling that of Plathelminthes) are fertilized outside of the parental body after the development of the two polar bodies. Their segmentation is unequal and leads to an epibolic gastrula. The larva greatly resembles the trochophora, although the absence of the preoral circle of cilia prevents a perfect comparison. The further development of the larva is very simple. A real body cavity is not present; parenchymal tissues traversed by muscle fibres takes its place.

The body of the Hinudinei is elongated, in most cases dorso-ventrally flattened, rarely round. The numerous circular furrows do not correspond to the internal segH* 
ments; three, four or five external rings belong generally to one internal segment, with the exception of the opposite terminal rings, which exactly correspond to the internal arrangement. The number of segments may be determined by the number of these external rings, which carry sensory organs and are always constant. The integument is naked and without appendages (except in Pontobdella and Branchellion). The cutaneous muscular structure is characterized by diagon. ally intersecting fibres. The pharyngeal apparatus of the Rhynchobdellidæ corresponds very minutely to that of some Plathelminthes; it is a pharynx plicatus which protrudes from the mouth opening but is not evaginated. In the Gnathobdellidæ the muscular wall of the œsophagus itself is thickened and protrudes in form of three longitudinal folds or septa into the lumen. These septa may be developed into jaws covered with fine teeths. Well developed muscular fibres radiate from the pharyngeal wall to the body wall. The midgut exhibits laterally paired, segmentallly arranged diverticula, the last pair of which is very long, extending posteriorly along the sides of the hindgut. Here also modifications occur. The body cavity has not yet been defined. The space between alimentary canal and body wall is filled with connective tissue or parenchyma, subject to manifold transformations. The difficulty which arises in determining the body cavity is largely due to the fact that in all Hirudinei the blood-vascular system stands in open communication with the sinuses, which may or may not be lined with an endothelium. Attached to the dorsal and ventral body wall muscle fibres extend through the parenchyma, which branch at both ends and form metamerically arranged muscle dissepiments between the 
alimentary diverticula. The structure of the nervous system is in a general way the same as that of the Chrtopoda. Important specific characteristics are found in the sensory organs. The eyes of worms in general need not necessarily be homologous, except the larval eyes of the trochophora type, which either disappear or are reduced. We mention here especially the fire pairs of eyes found on five sensory rings of Hirudo medicinalis. The structure of the Hirudinean eye is characteristic. It is cylindrical, situated almost vertically upon the hypodermis. The nerve enters at the basal end, its fibrillæ changing into long sensory cells, which lie in the axis of the eye. Large, muscular, pellucid cells surround this axis, and the whole eye is embedded in a highly pigmented connective substance. In the sensory organs the long sensory cells are of hypodermic character; the large, transparent cells are comparatively few, and the pigment is wanting. Their function is problematic. On the lips organs of taste occur. The nephridial structure of the Hirudinea resembles that of the Oligochrta, except that in the segments of the opposite ends the constant nephridia are wanting. The blood-vascular sy'stem consists of four longitudinal vessels of a supraintestinal, a ventral (in which the nerve lies), and of two (pulsating) lateral ressels. The ventral vessel may be looked upon as the chief part of a reduced body cavity. A network of lateral branches may connect the longitudinal vessels at both ends. The peripheral vascular system consists of two networks of capillaries, one extending through the integument, and the other along the alimentary canal. The organs of excretion and reproduction are richly supplied with blood vessels. The blood consists of colorless amœboid corpuscles and 
free nuclei. Many modifications occur. In all other respects the Hirudinei resemble closely the Chætopoda. They are hermaphrodites. Several paired testes lie segmentally arranged in the median body region between the successive lateral diverticula of the midgut, within the muscular septa. They all open into a vas deferens lying along the whole region. The two vasa deferentia converge anteriorly towards the ventral median line, and open in a common aperture (sometimes through a penis).

The female apparatus lies behind the male opening, between the vasa deferentia and consists of two ovaria, where oviducts either enter the large muscular vagina ( 2 . suborder), or lead directly to the outside (I. suborder.)

The structure and deposition of the eggs is generally the same as in the Oligochæta. Although different in detail, the whole course of their development corresponds to that of the Chætopoda (Oligochæta). The so-called germ-streaks of the Hirudinea and the mesoderm streaks of the Chætopoda do not, indeed, appear to be homologous structures, but their relation to the embryonic body and their later development show that they both may be traced back to similar forms; the mesoderm streaks of the Hirudinei assumed a more complicated structure through the addition of ectodermal parts. The same may be said of the origin and structure of the organs, except that the genital organs resemble those of the dendrocœlous Turbellaria. On the whole, it must be acknowledged that the Hirudinei are more highly developed forms.

The systematic position of Branchiobdella is still a matter of dispute. Anatomically it resembles the Oligochæta, but in its development and parasitic habits it approaches more closely the Hirudinei. A proper inves- 
tigation of the origin of the nervous system and the mesodermal bands will reveal its true nature. So far nothing definite can be said about it.

The structure of the Prosopygii has already been described in its most important features. The different orders present great variations. The Sipunculacea exhibit a regular external segmentation, the rings corresponding to the muscular bundles of the circular muscular layer, and to the lateral commissures of the ventral nerve trunk. The presence of longitudinal furrows divides the external integument into squares. Papillæ and wartlike projections appear especially along the proboscis. The proboscis is the anterior part of the body which can be invaginated into the posterior, the mouth being situated at its anterior termination. It includes also the foregut. The Spunculacea possess a firm cuticula; that of Phoronis is delicate, but a chitinous, separate $\mathrm{dwelling}$ tube is secreted. The tough, cuticular envelope of the Bryozoa (frequently with lid) becomes calcareous in many cases. The mantle of the Brachiopoda secretes in a similar way a bivalved, generally calcareous shell. The shell can hardly be compared with the bivalved shell of the Mollusca. The valves are dorsal and ventral; each one is symmetrical and the median plane divides each one into two lateral congruent halves; the opening is anteriorly and the hinge posteriorly situated. The hypodermis of the Bryozoa almost vanishes in the thick cuticula. In the Priapulidæ and Phoronidea the elements of the central nervous system and the hypodermis cells are so blended together that a line of demarkation can hardly be drawn. The general muscular structure of the Prosopygii differs widely. The naked Sipunculacea possess a typical cutaneous muscular envelope, consist- 
ing of an external circular and internal longitudinal muscular layer, between which a thin, diagonal, fibrous layer is inserted. The retractors of the probocis are longitudinal muscles, attached in various numbers either to its anterior end or to the cutaneous muscular envelope of the anterior or central region of the body and extending freely through the body cavity. The cutaneous muscular layer of the Phoronidea is typically composed of the two layers. There is none in the Bryozoa; at least the formation of a rigid cutaneous skeleton (shell, cell, ectocyst) has reduced it to a set of muscles which permit the retraction and protrusion of the soft anterior end and its tentacles or a contraction of the body stalk movable within a tube. The typical cutaneous muscular envelope is likewise absent or at least much reduced in the Brachiopoda, due to the formation of a shell. Its remnants are a few feebly developed transverse and longitudinal fibres beneath the integment of the mantle; further, the muscles of the arms (protractors and retractors) and the longitudinal muscles of the stalk. A system of strong dorso-ventrally situated muscles, attached near the hinge to the two valves (adductors and divaricators), serve the purpose of opening and closing the valves. They cannot be looked upon as modified parts of a cutaneous envelope.

The alimentary canal is generally well developed (blind in the Testicardines). The foregut is very short and not strongly differentiated, because the taking in of food is mostly accomplished by special external appendages. Only the Priapulidæ exhibit a well developed pharynx with numerous teeth and a strong muscular structure. In the Phoronidea, Bryozoa and Brachiopoda the foregut simply represents the rarely distinct and muscular connection between mouth and stomach, 
commonly called œsophagus. Whilst the midgut of the Priapulidæ extends as a straight tube tlirough the body, that of the Sipunculidæ bends at the posterior termination and returns to the anterior region, winding spirally around the first portion. A ciliated furrow runs along the midgut; near the end a blind diverticulum takes its place corresponding to the secondary canal of "the Chætopoda. Phoronis exhibits a similar descending and (dorsally) ascending midgut. In the Bryozoa a stomach intervenes which sometimes lengthens into a blind sac. The midgut of the Brachiopoda consists of an anterior portion of the stomach, into which the œsophagus leads, and a gastric canal. Lateral evaginations of the stomach form voluminous lobes, (the liver) which completely envelop it. The gastric canal forms a simple or complicated loop variously ending. The two anal organs of the Priapulidæ, serving first as excretory organs then as genital canals open externally near the anus. In Sipunculus rudimentary anal glands have been observed opening into the last part of the hindgut. The anus of the Sipunculidæ lies dorsally between proboscis and body wall; in Phoronis and Bryozoa without or within the base of the tentacle; in the Brachiopoda, when present, to the right of the mouth (Crania excepted). In the Priapulidæ it is situated at the posterior end. The body cavity of the Sipunculacea is large and spacious; dissepiments are wanting; the alimentary canal is fastened to the body wall by delicate mesenterial cords (absent in Priapulidæ). In Priapulus the body cavity continues into the tail appendage. The alimentary peritoneum of the Sipunculidæ is largely ciliated, a longitudinal band of muscles extends along the canal. The body fluid contains amœboid $1 \mathrm{mmph}$ cells, genital pro- 
ducts and other unknown substances. In Phoronis a system separates the cavity of the cephalic lobe from the body cavity; mesenteries attach the alimentary canal to the body wall. The body cavity of the Bryozoa is reduced in some cases and well developed in others. Muscular (?) fibres fasten the alimentary canal to the body wall; one or two funiculi attach the blind cœcum to the posterior body wall. The body cavity of the Brachiopoda is lined by a largely ciliated entothelium. A dorso-ventral mesentery dividing the cavity into two lateral halves fasten the alimentary canal to the body wall. Sometimes a gastro-parietal band and a ileoparietal band are also present in the region of the hindgut. These bands have been compared to septa which originally divided the body into three segments. The body cavity continues into the mantle cavities. The nervous system of the Sipunculacea begins with an œsophageal ring around the anterior end of the alimentary canal, joining dorsally a well developed brain (only thickened in Priapulidæ), whence commissures are given off to the anterior integument and the tentacles. Nerves proceed from the œsophageal ring innervating the alimentary canal (two in Sipunculus) and the pharynx (4 in Priapulus). The ganglionic ventral cord sends off lateral branches which dorsally unite into rings, corresponding to the external rings; or simple regular segmental swellings of the ventral cord occur (Priapulus). The nervous system of the other Prosopygii is very little developed. The ventral cord is reduced to the lower œsophageal ganglion, but even this can be wanting. This peculiarity is probably due to their sessile habit which caused a degeneration of the sensory organs. Phoronis possesses a nerve which proceeds from the dorsal side of the œsophageal 
ring and extends, lying asymmetrically on the left side, along two thirds of the body; inside of it a tube (notochord?) occurs. In the Brachiopoda nerves enter two by two the arms, the mantle and the retractory and protractory muscles of the body, which branch out again. In the Bryozoa nerves enter the tentacles. The nephridial system of the Prosopygii is but little developed. Never more than two pairs of nephridia occur. They serve as ducts for the genital products and may also have excretory functions. They open near the arms in the Sipunculidæ; they are wanting in the Bryozoa (except Entoprocta); in the Brachiopoda they are situated to the right and the left of the mouth and open in the mantle cavity. So-called anal tubes occur in the Sipunculacea, either open or closed, serving the same purpose as the nephridia. As organs of respiration serve the tentacles or the oral arms which are either penetrated by blood ressels or by vascular processes of the body cavity. Also the integument and tail processes may perform the same function. The blood-vascular system is wanting in the Priapulidæ and the Bryozoa. Sipunculus possesses a dorsal and a ventral vessel accompanying the foregut and opening anteriorly into a circular sinus embracing the mouth cavity at the base of the tentacles; posteriorly it ends in the region where the retractor muscles of the proboscis are attached to the body wall. There is probably an open communication between body cavity and vascular system. In Phoronis a closed vascular system with red blood corpuscles is developed, consisting of a dorsal and ventral vessel, with anterior circular and many posterior, lateral, blind vessels; the gastric canal is surrounded by a blood sinus. All vessels are contractile. The existence of an apparatus of blood circulation 
in the Brachiopoda is dispisted. It has however been repeatedly confirmed that a contractile tubular heart lies above the gastric cavity and a vein proceeding from above the foregut. There are also other blood vessels claimed to be present. Ova and spermatozoa of the Sipunculidæ, Phoronidæ and Brachiopoda arise at certain points from the entothelium of the body cavity. The genital products fall into the body fluid and are emptied through the nephridia. The anal ducts of the Priapulidæ are first excretory organs but become afterwards germ-glands and eductory passages. The sexes of the Bryozoa are either represented by different persons, or they are present in one. The ovaria of the Ectoprocta arise mostly as cell cumulations of the internal body wall, the testes on the funiculus. The statoblasts of the parthenogenetic Bryozoa are parthenogenetic eggs and located on the funiculus. Eggs and spermatozoa fall into the body cavity. How they are emitted has not yet been determined with any degree of certainty. The first stages of the development of Sipunculus are not known. Hatschek obtained the pelagic embryos in the blastula stage which already shows the structure of the three germ layers. The free swimming larva is more highly developed than the trochophora of the Polychæta to which it generally corresponds. The characteristic preoral circle of cilia is however wanting (present in Phascolosma), but the postoral circle is highly developed. The characteristic anterior position of the anus is due to the extremely rapid growth of the postanal region of the body as compared with the preanal. There is no cephalic nephridium present. The mesoderm is, however, much further developed than in the trochophora of the Polychæta. The spacious body cavity does not correspond to 
the primary body cavity of the trochophora, but to the secondary body cavity of the Annulata which develops within the mesoblast bands. Segmentation does not take place. The development of Phascolosoma is much simpler. Here an original epibolic gastrula changes into a kind of invagination gastrula. The larva coincides more closely with the trochophora; segmentation is likewise wanting. This latter fact necessitates the separation of the Sipunculidæ from the Echiuridæ, with which they formed the Gephyrea, a subdivision of the Annelides.

It is a very difficult matter to assign the Bryozoa their proper place in classification. We have already said, under the head of Entoprocta, that they have to be separated from the Bryozoa, because they exhibit a different phylogenetic origin. However, although the larva of the Ectoprocta (of Membranipora) is apparently of a very different structure it is, nevertheless, reducible to the same type as that of the Entoprocta, but the latter retain in the structure of their bodies and the formation of their colonies essentially the organization of the Bryozoan larva.

The larva of Phoronis is known by the name Actinotrocha. Mouth and anus are situated at opposite ends of the ciliated larval body. A large cephalic lobe extends over and beyond the mouth, the margin of which is supplied with larger cilia; the whole resembling the preoral, ciliated ring of the trochophora. The rertex plate of the cephalic lobe is supplied with four eye spots. Behind the mouth are two successive rings of larral and adult tentacles respectively. At the base of the latter the nerve ring of the adult is formed. Back of them, at the ventral side, lies the embryonic adult body projected into the larval body, which fact distinguishes this larva from that of Sipunculus, which it otherwise resembles. On either 
side a nephridium is developed, corresponding to the cephalic nephridia of the trochophora and forming the nephridia of the adult Phoronis. Around the anus a thick circle of cilia is situated. The Actinotrocha sinks to the bottom, the body trunk is evaginated and the alimentary canal formed. The cephalic lobe, the vertex and the larval tentacles are cast off and eaten by the young Phoronis. The remaining part of the larval body grows little, and the anus retains its dorsal position near the mouth.

The free swimming larva of Argiope (Brachiopoda) consists of three successive segments, the anterior, middle and end segment. The umbrella-shaped anterior segment contains four eyes; its margin has larger cilia than the rest of the surface. A dorsal and ventral fold attached to the middle segment covers the terminal segment. In either side of the free edge of the ventral fold two bundles of bristles occur. Only the midgut is developed. A paired secondary body cavity, mesenterics and muscles, is situated between alimentary canal and external larval integument. The larva fastens itself by the end of the terminal segment which grows into a stalk. The two folds develop into the mantle, within which the reduced anterior segment is contained. The bristles are cast off. The stomodæum arises from a deepening of the anterior body wall, whose base breaks through and into the anterior end of the midgut. The eyes degenerate. No traces of system and nephridia observed. The larva of Terebratulina shows a close relationship with that of Phoronis. It manifests itself in the formation of a tentacular disc on the dorsal mantle lobe and its lengthening into two processes, the arms which carry the cirri. The umbrella-shaped anterior segment probably corre- 
sponds to the vertex of Phoronis, and the terminal segment of the Brachiopedal larva to the evaginating stalk of Actinotrocha. The oral nerve rings of the two may be homologous.

The Chatognatha resemble externally the Rotatoria. The cutaneous muscular envelope is very highly developed, owing to the extraordinary rapidity with which these animals move through the water. The circular layer, however, is wanting (Spadella excepted). The cephalic muscular arrangement is very complicated. Alimentary canal very simple. The nervous system is well developed. The central nervous system and the peripheral nerves (one exception) lie outside of the muscular structure within the body epithelium. We distinguish a supra- and a larger infra-œsophageal ganglion, connected by two large commissures. From the former proceed: two interior motor nerves, two lateral integumental nerves, two optic nerves and two olfactory nerves, extending to the sensory organs behind the eyes. From the infra-œsophageal or ventral ganglion rumerous lateral nerves are given off (to auditory vesicle) and the œsophageal commissures extend as two strong nerve cords along the ventral region of the body, sending out numerous lateral nerves which, together with the ganglion branches, form a nerve plexus extending beneath the whole body-epithelium. The motor nerves develop lateral cephalic ganglia with small accessory ganglia, which together enter the muscles of the head and the anterior arm. The paired oviducts and spermducts in the posterior end of the body may be looked upon as transformed nephridial organs. Organs of respiration and blood-vascular system are wanting. The Chætognatha are hermaphrodites. The ovaria are sit- 
uated in the lateral chambers of the anterior body cavity attached by mesenteries which at the same time envelope the oviducts (blind at the anterior end) that open externally near the septum between body and tail. The male apparatus resembles that of the Chætopoda, Sipunculidæ, Phoronis and the Brachiopoda. The two testes, situated along the lateral lines of the tail wall, empty the immature spermatozoa into the lateral chambers of the tail cavity, where they mature. They leave the body through the vasa deferentia, which consist of a ciliated funnel, a duct and a dilatation. The eggs of the Chætognatha are spherical, transparent, and contain numerous translucent little yolk spheres. Segmentation is total and equal, resulting in a regular blastula, which develops into an invagination-gastrula. Two large cells, the so-called genital cells, appear early at the bottom of the cœlom-invagination, opposite the blastopore. The plane which separates these two cells corresponds to the later planes of symmetry. The characteristic peculiarities in the development of the Chætognatha are, chiefly: The origin of the mesoderm through the formation of the two cœlom-diverticula and the early separation of the genital structure. Their embryonic and larval stage does not resemble the corresponding trochophora stages, which important fact distinguishes them from the Annelides. 


\section{ARTHROPODA.}

Bilaterally symmetric animals with chitinous exoskeleton, segmented body and joined segmented appendages on all or on a number of segments; with brain, œesophageal cominissure and segmented ventral nerve cord; with heart situated above the alimentary canal; sexes separate; with a pair of sexual glands and originally paired eductory passages.

I Sub-branch: BRANCHIATA. Aquatic animals. With the exception of the anterior antennæ all appendages are originally biramous. Respiration through integument or gills which are almost always basal attachments of the body appendages.

\section{Only Class : Crustacea.}

I Subclass: Entomostraca. The body consists of a variable number of segments. Frequently it is divided into an anterior portion with and a posterior portion without appendages. Both, however, may consist of a variable number of segments. The genital openings generally lie along the line which divides the two main body regions. A shield-like carapace is frequently present, but variously developed. Appendages manifold in form. Together with lateral eyes, the single frontal eye is retained in the adult animal. Chitinous stomach wanting. Development with metamorphosis. A Nauplius larva leaves the egg. Mostly small Crustacea. 
I. Order: Phyllopoda. Swimming feet with branchial sacs ; mandibles without palpi ; maxillæ reduced.

I. Suborder: Branchiopoda. Body distinctly segmented; with numerous segments and (paired) swimming feet. Carapace either flat or forming a bivalve shell, rarely wanting. Heart an elongated dorsal vessel with numerous pairs of ostia. Live in fresh water. Branchipus (without shell). Apus (with flat carapace). Estheria. Limnadia, with bivalve shell.

2. Suborder: Cladocera (Daphnidæ). Water-fleas. Body small, indistinctly segmented, with few segments and four to six pairs of swimming feet. The posterior antennæ are large paddle-like feet. Gill sacs may be wanting. With a bivalve shell. Head freely projecting. Female with dorsal brood pouch between shell and body wall. Heart sac-shaped with one pair of ostia. Mostly in fresh water. Daphnia. Sida. Moina. Lynceus. Polyphemus. Leptodora. Evadne (marine).

2. Order: Astracoda. Body small, consisting of few segments, indistinctly segmented, with bivalve shell. Besides the five anterior pairs of cephalic appendages, $i$. e., the antennæ, mandibles and maxillæ, all or some of which may serve as crawling or swimming feet, there are only two pairs of legs present. Heart present or wanting. Fresh water forms: Cypris. Marine forms: Cythere. Halocypris. Cypridina.

3. Order: Copepoda. With biramous or swimming feet.

I. Suborder: Eucopepoda. Body small, mostly-distinctly segmented, without shell-reduplicature. The shell consisting of only ten segments, the five anterior of which carry five pairs of biramous swimming feet, whilst the anterior ones are without appendages. First anterior segment fused with the head. Antennæ, mandibles and 
maxillæ (posterior maxillæ dissolved into its branches) well developed, at least in the non-parasitic forms; the parasitic forms with sucking or piercing mouth parts. Heart wanting; sac-shaped, when present. The females carry the fertilized eggs in a paired or unpaired ovarian pouch. Gills wanting. Non-parasitic Copepoda or Commensals: Cyclops. Canthocamptus (fresh water). Cetochilus. Clausocalanus (marine). Notodelphys, commensale in the branchial cavity of Ascidia. Parasitic Copepoda: Corycaus. Sapphirina (some only temporary parasites). Chondracanthus. Caligus. Lernea. Lernaocera. Penella. Lemanthropus. Lernceascus. Achtheres. Anchorella.

2. Suborder: Branchiura (Argulida). Carp-lice. The body consists of the shield-shaped, flattened cephalothorax and the short, flattened, longitudinally split abdomen. In front of the suctorial mouth-tube a long, protrusible stylet. Four pair of long, cirrus-like, biramous, swimming feet. Two large compound lateral eyes. Testes in the tail fin. Heart present. Females without egg pouches glue their eggs to foreign objects. Argulus, upon the carp.

4. Order: Cirripedia. Characteristic of sessile forms. Body indistinctly segmented, fastened by the head end, enveloped by a calcareous mantle, forming a shell or a case. Anterior antennæ (organs of attachment) of minute size, posterior ones reduced. Mouth appendages small, partly reduced. Six (more rarely four) pairs of long, biramous cirripedes. Without heart. Hermaphrodites, sometimes with dwarf males, more rarely of separate sex and dimorphous. Live in the ocean.

I. Family: Lepadida (Pedunculata). Head end drawn out into a long attached peduncle. Lepas. Conchoderma. Scalpellum. Pellicipes. Ibla. 2. Family: Balanida. Pe- 
duncle wanting. Body surrounded by an external ring of plates. Balanus. Tubicinella. Coronula. 3. Family: Alcippida (Abdominalia). Body surrounded by a flaskshaped, soft mantle, with three or four pairs of feet corresponding to the last four pair of the other Cirripedia. Live in the calcareous shells of other Cirripedia and of the Mollusca. Alcippe. Cryptophialus. 4. Family: Proteolepadida (Apoda). Body grub-shaped, without cirripedes. Anterior (clasping) antennæ band-shaped. Mouth suctorial. Alimentary canal rudimentary. Parasites in the mantle of other Cirripedia. Proteolepas. 5. Family: Rhizocephala (Kentrogonida) ought perhaps be separated as a special suborder or order from the other Cirripedia. Body tubular; only corresponding to the head region of related Crustacea Integument split into two lamellæ, between them a brood-cavity, opening through an aperture in the external lamella. Alimentary canal wanting. Appendages wanting. Hermaphrodites with dwarf males. Parasites in the abdomen of Decapoda. The saccular body bears a peduncle, with branched root-like filaments, which penetrate the interior of the host whence they carry the food to the body of the parasite. The larval stages are similar to those of the other Cirripedia (Nauplius and cipris-like larva). Sac. culina. Peltogaster.

II Subclass: Malacostraca. The body consists of three regions, with a constant number of segments. The head, originally composed of five segments ; the thorax, with eight segments; the first anterior, or more than one, or all of them, niay fuse with the head into a complete or incomplete cephalo-thorax; and the abdomen, composed (with the telson) of seven segments (of eight in Nebalia). All the segments of the thorax, 
with the exception of the last (seventh and eighth in Nebalia), bear appendages. The extreme anterior thoracic feet frequently approach the mouth opening as maxillipeds, and perform as such functions of nutrition. The sixth pair of pleopods is almost always of different structure, and constitutes frequently, together with the telson, a tail-fin. The lateral portion of the posterior part of the cephalic segments are free and developed as overhanging folds. A pair of compound lateral eyes and a chitinous stomach (crop) are present in all cases. The female sexual apertures are situated on the antepenultimate, the male on the last pair of the thoracic segments. Development either with or without metamorphosis. The larva leaving the egg is rarely a Nauplius.

I. Legion: Leptostraca. A very important group of Crustacea which stands nearest (among all living forms) to the ancestral type of the Malacostraca, and is frequently placed as a special subclass between the Entomostraca and Malacostraca. Body slender, covered by a bivalved carapace, except the four last abdominal segments. Besides a movable cephalic plate. Head, with its five pairs of typical appendages distinctly separate from the thorax. All eight segments of the short thorax distinctly marked, with eight pairs of uniform, biramous, lamellous, thoracic feet. At the basal portion of the protopodite a large epipodial lamella (serving as a gill). The four anterior pairs of pleopods are strong, biramous swimming feet, the two posterior pairs are short, biramous. The last segment of the abdomen bears two forked processes. Two stalked, compound, lateral cephalic eyes. Heart elongated, with seven pairs of ostia, extends 
through thorax and abdomen as far as the fourth abdominal segment. Chitinous stomach (crop) present.

Only order and family: Nebalida. Nebalia. Paranebalia. Nebaliopsis. Marine.

Related to the L,eptostraca, are the fossil, palæozoic, Ceratiocaride (Archæostraca): Hymenocaris, Ceratrocaris, etc.

2. Legion: Arthrostraca (Edriophthalmata). Carapace wanting (except in Anisopoda). The first thoracic segment (rarely the second) fused with the head, and the first anterior pair of thoracic feet correspondingly changed into maxillipeds. The two lateral eyes sessile.

I. Order: Anisopoda. First and second thoracic segment fused with the head. Cephalo-thorax with overhanging carapace, covering on either side a branchial cavity. The two pair of maxillæ with palpi. The palpi of the anterior pair protrude into the branchial cavity. On the maxilliped an epipodial appendage serving as a gill. The feet of the second thoracic segment (fused with head) are developed into strong pincers. Abdomen with biramous swimming feet. Heart in thorax, generally with two pair of ostia (in Apseudes only three). Apseudes. Tanais. Leptochelia.

2. Order: Isopoda. Body broad, often dorso-ventrally flattened. Only the first anterior segment fused with the head, the other seven free. No separate carapace The two pair of maxillæ without palpi. Abdomen generally short, often reduced, in most cases consisting of six segments with two branching lamellous pleopods, whose endopodites (generally) serve as gills. Heart in the abdomen, often extending into the posterior thoracic region, with one or two pairs of ostia. Cymo- 
thoida, hermaphrodites, either parasitic (fish), or nonparasitic: Cymothoa. Anilocra. Cirolana. Nerocila. Aega, almost exclusively marine forms. Spharomidoe free, mostly marine: Spharoma. Pranizida, free in the ocean, the first three thoracic segmeuts fused with the head. Anceida, females parasitic, males free: Anceus. Idotheida, free, largely marine: Idothea. Asellida: Asellus, fresh water form; Oniscida, terrestrial. Oniscus. Porcellio. The groups of the Bopyride and Cryptoniscidce contain parasites, which are largely hermaphrodites, with drvarf males. Females deformed. Bopyrus (with separate sexes). Gy'ge. Entoniscus. Cryptoniscus. etc.

3. Order: Amphipoda (flea-crabs). Body laterally compressed. In the typical Amphipoda only the first anterior thoracic segment, in the Caprellidæ and Cyamidæ the first two are fused with the head. The gills are tubular epipodial appendages of the thoracic feet. A well-developed abdomen bears six pair of biramous feet; the three anterior (stronger) ones serve as swimming feet, the posterior (posteriorly directed) are adapted for springing. Heart in thorax, generally with three, rarely with one or two pair of ostia.

I. Suborder: Crevettina. Head and eyes small. The maxillipeds fuse to form a large underlip with two pediform palpi. Marine forms: Corophium. Talitrus. Orchestia. Lysianassa. Fresh water form: Gammarus.

2. Suborder: Hyperina. Head and eyes large, the latter often divided into frontal and lateral eyes. Maxillipeds from a small underlip without palpus. Marine forms: Hyperia (eyes not divided). Phronima. Platyscelus Oxycephalus.

3. Suborder: Lamodipoda. Abdomen rudimentary and apodal. The two anterior thoracic segments fused 
with the head. Gills on the second and third free thoracic segments, legs of these segments often reduced. Marine forms. Caprellida. Body very thin and slender Caprella. Proto. Protella. Cyamida. Body broad and flat. Parasites on the skin of whales. Cyamus.

3. Legion: Thoracostraca (Podophthalmata). With a carapace which covers a larger or smaller portion of the thorax and fuses with the dorsal integument of all or some of the anterior thoracic segments, but always remains along the sides as a gill cover of the respiratory cavity. A variable number of anterior thoracic segments, or all of them fused (at least dorsally) with the head into an incomplete or complete cephalothorax. The two lateral eyes (except in Cumacea) stalked.

I. Order: Cumacea. Shell (cephalo-thoracic shield) small, leaves the five posterior free thoracic segments uncovered. Eyes sessile, closely approaching or fused into one, but little developed, sometimes wanting. Two pairs of maxillipeds. The first one with very large epipodite which bears a gill. Of the six following pairs of thoracic feet the two first ones always contain, besides the entopodites, also an exopodite; this is often the case with the three next pairs, but never with the last one. Abdomen long and slender. In the females the pleopods, except those of the last pair, are wanting. Marine forms. Diastylis.

2. Order: Stomatopoda. Cephalo thorax rather small, not covering the three posterior distinct thoracic segments. Body elongated, dorso-ventrally flattened. Abdomen large and well developed. The five anterior pairs of thoracic feet, situated near the mouth (mandibles and maxillipeds) are organs of prey, with epipodial lamel- 
$1 æ$, but without exopodites. The three posterior pairs are biramous, without epipodial appendages. The five pairs of anterior pleopods are strong lamellous swimming feet, whose exopodites bear gill tufts. The sixth pair of pleods forms, with the telson, a powerful tail-fin. The heart lengthens into a dorsal vessel, transversing the abdomen, and provided with several pair sof ostia, ovaria and testes in the abdomen. Marine. Squilla.

3. Order: Schizopoda. Cephalo thorax well developed, thin, covering the whole thorax; the dorsal integument of the five last or of the last thoracic segment is not fused with it. The eighth pair of thoracic feet are almost uniform and represent biramous feet (with exopodite and entopodite), but the two anterior pairs of abdominal feet may be called maxillipeds or foot-jaws, because they play the part of jaws. Abdomen strong, slender. Pleopods of the female very small, in the male very strongly developed. The last pair, well developed in both sexes, forms with the telson, a rowing or swimming fin. Marine. I. Family: Mysidece. Thoracic feet without gills, the first pair with large swinging epipodial lamella. The five last thoracic segments free beneath the dorsal shield. Auditory organs in the entopodites of the sixth pair of pleopods. Mysis, Siriella: (male with gills on the pleopods). 2. Family: Lophogastride. With gill tufts on the thoracic feet; five last thoracic segments as in Mysideæ. Lophogaster. 3. Family: Euphauside. With gill tufts on the thoracic feet. Only the last abdominal segment is free under the dorsal shieid. Euphausia, Thysanopoda.

4. Order: Decapoda. Cephalo-thoracic shield large, mostly firm and hard; calcareous, covering the whole thorax and fused with the dorsal integument of all 
thoracic segments. Exopodite of the second maxilla forms a vibrating plate which regulates the water current in the branchial cavity. The three anterior pair of thoracic feet are developed into maxillipeds, the five posterior (some armed with pincers) adapted for walking (therefore Decapoda). The ambulatory feet of adults only consist of protopodite and entopodite; the exopodite is wanting; auditory organs at the basal joint of the interior antennæ. Development direct or with metamorphosis. In the latter case the larvæ leaving the egg are generally advanced beyond the Nauplus stage passing through the Zoëa and Mysis stage. Extraordinarily rich in forms.

I. Suborder: Macrura. With well developed abdomen, which is at least as long as the cephalo-thorax. Mostly with the full number of pleopods, the last pair of which forms with the telson a strong tail-fin. Caridida: Penceus. Palamon. Crangon. Pontonia. Alpheus. Sergestes. Leucifer. Marine. Astacida: Astacus fuviatalis (cray fish in rivers). Homarus (lobster). Nephrops. Callianassa. Gebia. Palpinurida: Palinurus. Scyllarus. Marine.

2. Suborder: Anomura (not sharply distinct from the preceding). Abdomen tolerably large, tail-fin mostly reduced. The last or the two last pair of ambulatory feet rudimentary. Third maxilliped long and pediform. $P a$ gurida: Hermit crabs, marine, living in snail shells. Abdomen with soft integument, assymmetric with rudimentary pleopods serving as chelæ. Pagurus. Eupagurus. Birgus (in holes in the ground). Hippida, marine, living in the mud. Abdomen with solid integument, generally bent forward. The Galateide (Galatea) resemble the Macrura, the Porcellanide (Porcellana) the Brachyura.

3. Suborder: Brachyura. Body short and widened. Abdomen without anal fin, reduced, bent upon the ventral 
side of the cephalo thorax. In the male only the two anterior pairs of pleopods. Notopoda, marine. Dromia. Dorippe. Lithodes. Oxystomata (round crabs): Maja. Pisa. Stenorynchus. Inachus. Lambrus. Marine: Cyclo. metopa (bow crabs). Telphusa (in fresh water). Cancer (pocket crabs). Xantho. Pilumnus. Eriphia. Portunus. Carcinus. Marine. Catometopa (quadrangular crabs): Pinnoteres. Ocypoda. Grapsus (marine). Gecarcinus (land crabs).

I. Appendix. I Trilobita. No living species in existence. They all belong to the palæozoic age. The integument of the dorsal side is hard; the ventral side soft. The body is divided into three regions: cephalic shield, thorax and tail-shield (pygidium). Two longitudinal, almost parallel furrows, divide these three parts into a convex middle region (rhachis) and two lateral regions (pleura). The semi-circular or semi-1unar cephalic shield bears two large compound eyes. The thorax consists of a large number of movable segments, and the pygidium of a variable number of more or less fused segments. The animal was capable of bending the tail back upon the thorax. The appendages are rarely preserved. They are segmented, slender feet which are of uniform size from the cephalic shield to the pygidium. Four pair of maxillipeds, the anterior one (the strongest) inserted back of the (shell-like) upper lip. The other appendages are biramous feet consisting of a long entopodite, a short exopodite and a branchial thread- or band-shaped epipodial attachment. These gills are rudimentary in the pygidium. Marine animals. Agnostus (two thoracic segments). Trinucleus. Olenus. Paradoxides. Conocephalites. Sao. Calymene. Asaphus. 
Bronteus. Phacops. Cheirurus. Acidaspis. Lichas. Protus. Harpes.

II Gigantostraca. (Merostomea. Eurypterida); entirely extinguished. They likewise belong to the palæozoic age. Perhaps largest of all the Arthropoda. Body consists of head (cephalo-thorax?), thorax and abdomen. The unsegmented head is relatively small, carrying two compound lateral eyes and near the median line two ocelli. Thorax and abdomen consist each of six segments. To the sixth abdominal segment a styliform or fin-shaped telson is attached. Head region with six pairs of spiny appendages (not biramous). The first anterior pair constitutes either delicate, small antennæ (Eurypterus) or a long chela with powerful pincers; the basal joints of the others are inserted around the mouth. A jaw is attached to each of them, extending inwardly. The last pair of maxillipeds is much stronger than the others and oar-shaped, they evidently served as a swimming foot. Five plates consisting of two lateral halves and arranged like tiles on a roof, cover the leaf-shaped gills on the ventral side of the thorax. The anterior (largest) plate is called operculum. The abdomen is without appendages. There is a large oval plate behind the mouth, the metasoma. Eurypterus. Pterygotus.

III Hemiaspidæ. Extinct palæzoic forms; perhaps the connecting link between the Gigantostraca and the Xiphosura. Head with shield, thorax with five or six free segments (rarely fused), abdomen with three or more segments, terminated by a strong styliform telson. Two compound eyes, no ocelli. Two dorsal longitudinal furrows give the thorax the appearance of a Trilobite. Appendages unknown. Bunodes. Hemiaspis. Belinurus. IV Xiphosura (Pecilopoda. Limulida). Body covered 
with a thick, chitinous integument. Two parts: cephalothorax and abdomen, with a large, movable postanal styliform telson. Cephalo thorax almost semilunar, very large, with two lateral horns, directed posteriorly. On its dorsal side two compound eyes and two ocelli in front of them. The flat segmented abdomen, attached to the cephalothorax by a movable joint, has a somewhat hexagonal shape. Dorsal side convex, ventral side concave. Cephalothorax with seven pair of appendages, the first one (small, with pincers) corresponding to a second pair of antennæ (cheliceræ). The five following are stronger and longer, with jaw-like processes at the basal joint (modified in fifth) and pincers at the end (modified in fifth). They arise at the sides of the cleft-like month opening. Behind the mouth two style-shaped processes, the chilaria. The seventh pair of thoracic appendages resembles those of the abdomen; they consist of two plates (joined in the median line), which cover the five pair of leaf-shaped abdominal feet, and are called the operculum. Each abdominal foot consists of exopodite, entopodite and gill (integumental reduplicature). The gills are arranged like the leaves of a book. Abdominal feet also used for swimming. A sternal entoskeleton also occurs. Only genus: Limulus. Marine. L. moluccanus. East Indies. L. polyphemus. East Coast of North America.

\section{Appendix: Pantopoda (Pycnogonidæ). Body} much reduced, consists of rostrum, thorax and abdomen. Rostrum divided into a median upper and two lateral lower portions. At the anterior end the mouth with its three lips is situated. The thorax or main body-trunk consists of three fused and three free segments, exhibiting lateral processes to which the appendages are joined. 
Abdomen unsegmented, short, rudimentary, without appendages. The cheliceræ terminate in chelæ (in young animals) or are very much reduced if not wanting (in adults); the second pair shorter than the rest or wanting; the third pair, egg bearer in the males; often wanting in the females. The fourth, fifth, sixth and seventh pair are never wanting; they consist of nine segments, terminate in claws and are extremely long, which gives these animals a spider-like appearance. No biramous appendages. Marine animals. Nymphon. Palene. Phoxichilidium. Ammothea. Pycnogonum. Collossendeis gigas, a gigantic form in very deep water. The longest appendages may become $30 \mathrm{~cm}$. long, the whole body only $8 \mathrm{~cm}$.

II Sub-branch: TRACHEATA. Terrestrial. Appendages not biramous, consisting of one row of segments. Respiration by tracheæ (tubular or fan shaped).

I Class. Protracheata (Ony'chophora). Body wormshaped. A pair of preoral antennæe on the cephalic termination. In the mouth cavity a pair of horny jaws, at the sides of the mouth oral papillæ (salivary papillæ). Numerous short, almost rudimentary ambulatory. legs. Apodal abdomen. Breathing by tubular tracheæ, the external openings of which are scattered over the whole body. With numerous, segmentally arranged pairs of nephridia. With coxal glands (legs). Heart an elongated dorsal vessel with numerous pairs of ostia.

Only genus: Peripatus. Terrestrial animals living in dark damp places, beneath the bark of old trees, under stones, etc. P. Capensis. On the woody hills of the Table Mountains; Cape of Good Hope. P. Edwardsii. Venezuela. P. Nove Zealandice.

II CLASS: Antennata. (Myriopoda et Hexapoda.) A 
pair of preoral antennæ, three pair of oral appendages. Body either homonomously segmented with numerons segmented ambulatory legs, or heteronomously segmented, the appendages being confined to the three segments of the thorax, whilst the abdomen is apodal. Head and thorax distinct. Breathing by tubular tracheæ, whose external openings (stigmata) are segmentally arranged. Heart in all homonomous Myriopoda an elongated dorsal vessel (with many segmentally arranged pair of ostia), traversing the whole length of the body; in the Hexapoda, confined to the abdomen.

I. Subclass: Myriopoda. (Thousand legs.) Homonomously segmented Antennata with numerous body seg. ments, which are all, with the exception of the last one, provided with feet. Without compound eyes. With numerous ocelli.

I. Order: Symphyla. With not more than twelve body segments bearing ambulatory legs. A pair of branched tracheæ, with the stigmata in the head. Unpaired sexual aperture on the fourth segment. Scolo. pendrella. Scutigerella (Ryder).

2. Order: Chilopoda. Body dorso-ventrally more or less flattened. Every ring with only one pair of appendages corresponding to a segment. The two maxillæ separate. The first pair of ambulatory feet moved to the head as maxillipeds with poison gland opening from the terminal claw. Unpaired sexual aperture on the penultimate segment. Family: Scutigerida. With compound eyes. Body consists of fifteen segments with legs. Only ocelli. Lithobius. Henicops. Family: Scolopendrida. With twenty-one or twenty-three segments with appendages, (not counting the segment of the maxilliped). Body elongated. Scolopendra. Cryptops. Fam- 
ily: Geophilida. Body very long, with 3 I-I 73 segments with appendages. Geophilus. Himantarium.

3. Order: Diplopoda (Chilognatha). Body mostly arched. From the fifth segment to the end every ring bears two paired appendages, thus corresponding to a double segment. The two paired maxillæ fused into the so-called Gnathochilarium. Without maxillipeds. Paired sexual aperture between the second and third pair of legs. The legs of the seventh ring in the male modified into organs of copulation. Family: Polyxenida. Fifteen paired feet, Gnathochilarium rudimentary. Copulatory appendages wanting. Polyxenus. Family: Glomerida II-I4 eyes, I9-20 rings, 29-3 I pair of feet. Polydesmus. Brachydesmus. Family: Chordeumida. 30 rings, 45-50 pair of feet. Atractosoma. Craspedosoma. Chordeuma. Family: Lysiopetalide. Number of rings large, indefinite. Lysiopetalum. Family: Julida. 30-70 and more rings. Julus. Family: Polyzonide. Gnathochilarium rudimentary. Number of rings not constant, 30-100 and more. Polyzonium.

4. Order: Pauropoda. Antennæ forked with three flagella. Only one pair of feebly developed maxillæ. Ten body segments. Nine pair of appendages. Trachæa not yet discovered. Sexual apertures on the base of the second pair of legs. Pauropus. Eurypauropus (Ryder).

I. Subclass: Hexopada. Insecta. Heteronomously segmented antennæ, with an almost constant number of segments. The body consists of head, thorax (three segments) and abdomen (ten segments). Each of the three thoracic segments with one pair of feet. Abdomen apodal. Compound eyes almost always present; besides ocelli. Opening of the sexual organs always at the end of the abdomen. 
I. Legion: Apterygota. Without wings. Rudiments of abdominal appendages at least in the Thysanura. Without metamorphosis.

I. Order: Thysanura. With ten abdominal segments and two or three segmented bristle-like appendages (cerci) on the anal segment. Compound eyes and ocelli may be present or wanting. Machilis. Lepisma. Nicoletia. Campodea. Iapyx.

2. Order: Collembola. Spring tails. With six or less abdominal segments. Almost always a forked springing apparatus at the end of the abdomen. Without compound eyes. Sometimes with ocelli. Smynthurus. Podura. Isotoma. Macrotoma.

2. Legion: Pterygota. The second and third thoracic segment each with a pair of wings. Forms without wings occur, which are to be derived from winged ancestors.

I. Order: Dermaptera (Forficulida). Ear-wigs. Insects with gradual metamorphosis and biting mouthparts. Last abdominal segment with unsegmented appendages (cerci), forming pincers. Anterior wings short, modified into horny wing covers. Posterior wings large, delicate, fan-shaped; can be folded longitudinally and transversely. Sexual openings separate or rudimentary on one side. Forficula. Labidura.

2. Order: Orthoptera (straight winged). Insects with gradual metamorphosis, with biting mouth-parts, with two pair of thin or parchment-like wings (sometimes wanting). Anterior wings mostly shorter and more firmly chitinous than the posterior wings. Cerci of various forms on the abdominal cavity. Sexual aperture is unpaired. Embida, Blattida, cockroaches: Periplaneta. Blatta. Mantida: Mantis. Phasmida: Bacillus. Plasma. Phyllium. Saltatoria with the families of Acridiida (Ac- 
ridium, Edipoda, Mecostethus, Stenobothrus, Melanoplus, Tettix, etc.; of the Locustida: Locusta. Centhophilus. Xiphidium. Orchelimum. Conocephalus Cyrtophyllus. Amblycorphaa. Microcentrum. Scudderia. Thyreonotus, and of the Gryllida: Tridactylus. Gryllotalpa. Gryllus. Nemo. bius. Ecanthus.

3. Order: Ephemeridea. Insects with incomplete metamorphosis. Mouth parts rudimentary, after the type of biting insects. Posterior wings small or wanting, anterior wings large, wing texture thin and membranous. Abdomen with three (rarely two) long cerci. Paired genital ducts with separate apertures. Larvæ apneustic, resembling the Thysanura, with tracheal gills and biting mouth parts, live in water. Eyhemera. Palingenia. Chlöe.

4. Order: Odonata (Libellulide). Insects with incomplete metamorphosis, with biting mouth parts, Abdomen with two unsegmented anal stylets, Wings large, richly netted-veined, glassy. Thoracic legs moved forward. Larvæ in water, with variable tracheal gills, apneustic. Libellula. Aschna. Calopteryx. Agrion, etc.

5. Order: Plecoptera (Perlaria). Insects with incomplete or gradual metamorphosis; with biting mouth parts. Abdomen mostly with two long cerci. Both wings large, spacious cells between the veins, the posterior pair often broader than the anterior and capable of being partly folded. Larvæ thysonura-1ike, with tracheal gills, apneustic, aquatic. The tracheal gills often persist in the imago. Perla. Nemura.

6 Order: Corrodentia. Insects without any or with gradual metamorphosis, with biting mouth parts. Wings often wanting. Membranous in the Termitidæ, caducous 
in their sexual individuals; wanting in the workers. Several Psocidæe and Mallophaga are wingless. The latter also without compound eyes. The winged Psocidæ have glassy wings, with broad-celled veins similar to those of the Hymenoptera. Young Corrodentia resemble the Thysanura. Termitide, white ants, living in communities: Termes. Colotermes. Psocida, wood lice. Troctes (book louse). Psocus. Mallophaga, bird lice. Parasites. Trichodectes. Philopterus. Liotheum.

7. Order: Thysanoptera sive Physopoda. Insects with gradual metamorphosis, larva resembling closely imago. Last larval stage takes no food. Sucking mouth parts. The claws of the short feet changed with the hooked lobe of the tarsus into an evaginable bladderlike apparatus. Wings very narrow, with reduced system of veins, with long fringed margin; often wanting or rudimentary. Only three or four pairs of stigmata (one or two on thorax, one on the first and one on the eighth abdominal ring.) Nervous system concentrated. Thrips.

7. Order: Rhynchota. Insects with gradual metamorphosis (in the males of Coccidæ complete). Month parts form a rostrum adapted for piercing and sucking. Compound eyes wanting in parasitic Rhynchota.

I. Suborder: Phytophthires (plant lice). With two pairs of membranous wings, wanting in the females. The Coccidæ have only anterior wings, the posterior wings being changed into halters. Family: Psyllide, leaf-fleas, two pairs of wings, the anterior ones parchmentlike: Psylla. Livia. Family: Aphide, plant lice, two pairs of membranous wings, mostly wanting in the female: Aphis. Chermes. - Schizoneura. Phylloxera, Lachnus. Myzus. Family: Coccida, shield lice: Coccus Lecanium. Aspidiotus. 
2. Suborder: Pediculida (Aptera). Lice. Without facetted eyes and wings. Pediculus. Hamatopinus. Phthirius.

3. Suborder: Heteroptera (Hemiptera). Bugs. Wings (partly wanting). Anterior wing covers horny, tips membranous. Posterior wings membranous. Geocores, land bugs: Hydrometra. Halobates. Pentatoma. Coreus. Corizus. Alydus. Pyrrhocoris. Lygaus. Miris. Capsus Acanthia (bed bugs), Reduvii, etc. Hydrocores, water bugs: Nepa. Ranatra. Naucoris. Corixa. Notonecta, etc.

4. Suborder: Homoptera. Anterior and posterior wings uniform, membranous, the front pair generally coriaceous. Cicada. Pseudophana. Centrotus. Aphrophora. Tettigona. Ledra, etc.

9. Order: Neuroptera. Insects with complete metamorphosis and biting mouth-parts. Two pairs of mem. branous wings, the nervures of which form a network, transparent. Family: Megaloptera. Myrmeleon. Mantispa. Hemerobius. Chrysopa. Family: Sialida. Larvæ aquatic with tracheal gills. Sialis. Corydalis. Raphidia.

Io. Order: Panorpata. Insects with complete metamorphosis and biting mouth-parts. Two pairs of membranous, narrow wings with spacious cells between the veins. Larvæ caterpillar-like. Panorpa. Bittacus. Boreus (wings rudimentary).

I I. Order: Trichoptera (Phryganide). Spring flies. Insects with complete metamorphosis. Mandibles rudimentary. Maxillæ form a membranous, obtuse rostrum. Body mostly laairy, rarely scaly. Posterior wings generally larger than the anterior, can be folded like a fan. The grub-like larvæ live in dwelling tubes or cases, mostly in water, possessing tracheal gills and are apneu- 
stic. Phryganea. Limnophilus. Halesus. Hydropsyche. Mystacides, etc.

I2. Order: Siphonatera sive Aphaniptera. Fleas. Insects with complete metamorphosis, with sucking and piercing mouth-parts. No wings. No facetted eyes. Parasites. Pulex. Sarcopsylla. Ceratopsyllus.

I3. Order: Coleoptera. Beetles. Insects with complete metamorphosis and biting mouth-parts. Anterior wings (wing covers) horny Posterior wings membranous, may be folded transversely and longitudinally, used exclusively for flying. Larvæ of different form, often resembling a Thysaneura, sometimes a grub, rarely without feet (Curculionidæ), with biting mouth-parts. Several thousand genera with more than 80,000 species.

I. Suborder: Cryptotetramera. Tarsi composed of four joints, of which one is rudimentary. Families: Coccinellida. Eudomychidice.

2. Suborder: Cryptopentamera. Tarsi five-jointed, one rudimentary and concealed. Families: Chrysomelida. Cerambycida. Curculionida. Bostrychida, etc.

3. Suborder: Heteromera. The tarsi of the two anterior pairs of legs five-juinted, those of the others fourjointed. Family: Meloida (Cantharidæ). Rhipiphorida, Tenebrionida. Edemerida. Cistelida, etc.

4. Suborder: Pentamera. All tarsi generally fivejointed. Families: Xylophaga. Malacodermata. Elaterida. Buprestida. Lamellicornia. Silphida. Pselaphida. Staphylinida. Hydrophilida. Dytiscida. Carabida. Cicindelida, etc.

I4. Order: Lepidoptera. Butterflies. Insects with complete metamorphosis and suctorial mouth parts, which mostly form a spirally rolled proboscis. Body corered with scales. Both pairs of wings uniform, membra- 
nous, covered with scales, rarely capable of folding. Posterior wings generally somewhat smaller than the anterior. Larval caterpillars with anal feet, with biting mouth parts, rarely (Micropteryx) apodal.

I. Suborder: Microlepidoptera. Families: Pterophorida. Tineida. Pyralida. Tortricida.

2. Suborder: Geometrina. Loopers. Families: Phytometrida. Deudrometrida.

3. Suborder: Noctuina. Owls. Families: Ophiusida. Plusiade. Agrotide. Cuculliade. Acronyctide, etc.

4. Suborder: Bombycina (Silkworm moth). Families: Bombycida. Saturnida. Psychida. Zyganida. Cosside. Siparida. Euprepiade. Notodontida.

5. Suborder: Sphingina. (Sphinx moths.) Family: Sesiada. Sphingida.

6. Suborder: Rhopalocera. Butterflies. Families: Hesperide. Lycanide. Satyrida. Nymphalide. Heliconiida. Equitida.

I 5. Order: Hymenoptera. Insects with complete metamorphosis, with biting mandibles, and mostly suctorial maxillæ. Generally four membranous transparent, sparely veined wings. Caterpillars variable, apodal (with the exception of the leaf and wood wasps which have caterpillar-like larvæ), i. e., grubs.

I. Suborder: Terebrantia. Female with ovipositor as tube or borer (terebra). Families: Tenthredinida (leafwasps). Urocerida (wood wasps). Cynipida (gall flies). The larvæ of: Pteromalida, Braconida, Ichneumonida, Evaniada are mostly parasites in the larvæ of other insects.

2. Suborder: Aculeata. Female with poison sting and poison gland. Family: Formicide (ants). Fossoria (digging wasps). Vespida (wasps). Apida (bees). 
I6. Order: Diptera. Two-winged. Insects witb complete metamorphosis, with suctorial and frequently also stinging mouth parts. Anterior wings membranous, transparent. Posterior wings transformed into halters (swinging plates). Larvæ grub-like (apodal), with or without head.

I. Suborder: Pupipara. Sheep ticks, bird and bee lice. Vivaparous. The larvæ are born shortly before their entering upon the pupa stage. Parasites. Wings frequently rudimentary. Melophagus. Braula. Nycteribia.

2. Suborder; Brachy'cera. Flies. Antennæ short, consisting mostly of three segments. Numerous families: Muscida. Conopida. Estrida. Syrphida. Empida. Asilida. Bombyliida. Therevida. Tabanida. Leptida. Xylophagida. Stratiomyida.

3. Suborder: Nemocera (Tipularia). Mosquitos. Antenna long, several segments; males often with tufts of hairs. Families: Bibionida. Fungicola. Noctuiformes. Culiciformes. Culicida. Gallicola. Limnobiida.

NotE.-The Dermaptera are generally classified as a family with the Orthoptera. The Ephemeridea, Odonata, Plecoptera Corrodentia and Thysanoptera are frequently united under the head Pseudoneuroptera and the Panorpata are united with Neuroptera.

III CLASS: Arachnoidea sive Chelicerotă. Spiderlike Arthropoda. No preoral appendages resembling the antennæ of the Antennata and Protracheata. Several anterior body segments (seven, including cephalic lobe) are fused into an unsegmented region, called cephalothorax, with six pairs of appendages, of which the first anterior one is moved in front of the mouth. The first two anterior pairs are developed as oral appendages, the 
first one being called cheliceræ, the second one pedipalpi. The three other pairs of appendages are segmented, mostly long legs. Abdomen segmented or unsegmented or fused with the thorax, without developed appendages. Breath either exclusively by plicate tracheæ or by plicate and tubular tracheæ at the same time, or exclusively by tubular tracheæ. Number of segments limited, four pairs at most. The stigmata are almost always situated on the abdomen. Heart confined to the abdomen, rarely wanting.

I. Order: Scorpionidea. Scorpions. Body divided into a stout unsegmented cephalo thorax and a long, segmented abdomen. The latter consists again of a thick and broad preabdomen with seven segments and a narrow, elongated postabdomen with five segments. The last segment carries a poison sting. On the ventral side of the second abdominal segment two lateral comb shaped appendages. Cheliceræ and pedipalpi terminate in claws. Pedipalpi with large chelæ, four pairs of plicated tracheæ (lungs) whose stigmata are situated along the ventral side from the third to the sixth abdominal segments. Euscorpius. Buthus. Androctonus.

2. Order: Solpugidea. Head separate. Thorax with three segments; abdomen with ten segments, cylindrical. Cheliceræ with claws, pedipalpi long, serving. as ambulatory legs. Tubular tracheæ. A pair of stigmata on the first thoracic segment and one on the second and third abdominal segment respectively. Galeodes. Solbuga.

3. Order: Pseudoscorpionidea (Chernetide). Cephalothorax unsegmented or with two transverse furrows, abdomen broad, flat, with eleven segments. Neither poison-sting nor caudal spine present. Cheliceræ and 
pedipalpi as in second order. Tubular tracheæ. Two pairs of stigmata on the second and third abdominal segment. With spinning glands. Small animals. Chernes. Chelifer. Obisium. Chthonius.

4. Order: Pedipalpi (Thelyphonide). Scorpions and spiders. Cephalo-thorax unsegmented, distinct from the abdomen. The latter pressed down, consisting of eleven or twelve segments. Cheliceræ claw-shaped. Pedipalpi large, terminating either in a claw or in chelæ. First pair of legs with flagellate termination antenna-like. Two pairs of plicate tracheæ whose stigmata lie on the ventral side of the second or third abdominal rings. Thelyphonus (three last abdominal segments form a rudimentary region distinctly separate from the rest of the abdomen, and carrying a long, segmented caudal spine). Phrynus.

Here belong perhaps also the comparatively unknown groups of the Tartarida and Microthelyphonida.

5. Order: Phalangidea. Cephalo-thorax unsegmented, abdomen thick and stumpy, its whole breadth joining the cephalo-thorax, consisting of six segments, with chelate cheliceræ; the pedipalpi serving as ambulatory legs, legs often extraordinarily long and thin. Tubular tracheæ, with one pair of stigmata which lies ventrically along the separation line of cephalo-thorax and abdomen. Without spinning glands. Phalangium. Leiobunum. Gonyleptus.

6. Order: Cyphophthalmidea (often classified as a family to the preceding order). Cephalo-thorax unsegmented, abdomen with eight segments. Habit of the Pseudoscorpionidæ. Cheliceræ and pedipalpi similar to those of Phalangidæ. Tubular tracheæ. Cyphophthalmus (without spinning glands, with one pair of stigmata on 
the ventral side of the first abdominal segment). Gibbocellum (spinning glands on the base of the abdomen behind the sexual aperture; two pairs of stigmata on the second and third abdominal segment )

7. Order: Araneidea. Spiders. Cephalo-thorax and abdomen unsegmented, the latter large and oval shaped. Abdomen separated by a narrow short stalk from the cephalo-thorax. Four to six pairs of spinning mammillæ at the end of the abdomen. Cheliceræ chelate with poison gland. Pedipalpi serving as ambulatory legs. Terminal segment of the male modified for purposes of reproduction. Either exclusively plicate tracheæ or both plicate and tubular tracheæ.

I. Suborder: Tetrapneumones. With four plicate tracheæ, without tubular tracheæ. The two pairs of stigmata ventrally behind the base of the abdomen. Mostly four (Atypus six) spinning mammillæ. Mygale (Avicularia). Cteniza. Atypus.

2. Suborder: Dipneumones. With two plicate tracheæ which open with two stigmata on the base of the abdomen and with tubular tracleæe, opening in an unpaired (rarely paired, Dysderidæ) stagma, behind the stigmata of the plicate tracheæ. The unpaired stigmata of the tubular tracheæ has moved far back, now lying before the spinning mamillæ. With six spinning mammillæ. Here belong most spiders spinning webs. Family: Dysderida (two stigmata for the plicate tracheæ). Dysdera. Segestra. Family: Saltigrade, jumping spiders: Salticus. Attus. Family: Citigradce (Lycosidæ), wolf spiders: Lycosa. Tarantula. Family: Laterigrada, crab spiders: Micrommata. Philodromus. Xysticus. Family: Tubitelarice, tube weavers: Dictyna. Tegenaria. Agelena. Argyroneta. Drassus. Clubiona. Family: 
Retitelaric, net spiders: Linyphia. Theridium. Pholcus. Family: Orbitelaria, orb weavers: Epeira. Zilla. Meta.

8. Order: Acarina, Mites. Abdomen fused with the cephalo-thorax. Body unsegmented. Biting or stinging and suctorial mouth parts. Respiratory organs wanting or, if present, tracheæ. Many mites are parasites. A. Mites with tracheæ. Family: Trombidiida: Trombidium. Family: Tetranychida: Tetranychus. Family: Hydrachnida, water mites: Atax. Hydrachna. Hydrodoma. (The subfamily of Halacaridæ, sea mites [Aletes. Halacarus] without tracheæ). Family: Bdellida. Bdella. Family: Oribatide: Oribata. Leisoma. Family: Gamasida, beetle-mites: Gamasus. Uropoda. Family: Ixodide, ticks: Ixodes. Argus. B. Mites withont tracheæ. Family: Tyroglyphide, cheese-mites: Tyroglyphus. Family: Dermaleichida: Listrophorus, Analges. Family: Sarcoptida, itch-mites: Sarcoptes. Family: Demodicide: Demodex (in hair follicles of domestic animals and mian). Family: Phytoptida, gall-mites. Phytoptus.

Appendix: Linguatulida (Pentastomida). Body wormlike, mostly flattened, externally segmented. No mouth apparatus. Two pairs of movable hooks around the mouth. Sensory organs and tracheæ are wanting. Male aperture behind the mouth, female aperture on the posterior end of the body. Parasites. Pentastomum. $P$. tanioides. In the nose and mouth cavity and cerebral sinus of dog and wolf. Embryos are expelled with the mucous of the nose and swallowed by hare or rabbit or other mammals, through whose alimentary canal they penetrate the liver and lungs. Here it encysts and undergoes a remarkable metamorphosis, resulting in the 
larva Pentastoma denticulatum. It breaks through the capsule and moves freely about, finally entering again the mouth of a mammal.

Organization of the Crustacea. The external structure of the Crustacea is of the highest interest for comparative anatomy. The chitinous envelope which covers the whole body and its appendages, does not only serve as a protection for the internal organs, but also as a skeleton to which the muscles are internally attached. There are, therefore, intimate relations between external and internal organization. We consider: (I) the main bodyregion, (2) the appendages, (3) the gills:

The main body-region, i. e., the body, without its appendages consists of a number of successive segments (metameres), which are connected by movable joints, the chitinous envelope remaining thin and soft between successive rings. Originally the number of body segments corresponded to the number of appendages, the anterior or head segment being distinguished by the presence of eyes, mouth, brain and antennæ (different from the other uniform appendages), whilst the last segment (without appendages) contained the anus. But no known Crustacean exhibits such a regular segmentation. On the contrary, the anterior region of all Crustacea is externally unsegmented, and bears not one, but five pairs of appendages. One cephalic segment may have fused with four successive segments. This unsegmented anterior region is called the head. All the rest of the body may be termed the trunk. (See classification for distinction of subclasses with regard to number of segments.) We may assume that the same segments correspond in different Crustacea, e. g., the second or sixth or tenth trunk segment of an Isopod to the second, sixth 
or tenth of a Phyllopod. Likewise, since the segments differentiate ontogenetically from the anterior to the posterior end, as in the Annulata, it may be assumed that the anal segment is the same in all Crustacea. The regularity of segmentation may be either disturbed or disappear altogether: (I) through the appearance of a shell or shield (integumental reduplicature), which is very general and may be an ancestral peculiarity of the Crustacea (segmentation disappears by fusion); or (2) trunk appendages may acquire nutritive functions, and join the cephalic appendages so that their segments fuse with the head segment; or (3) other appendages may lose their functions (locomotory) and degenerate, which results in a reduction of the corresponding segments; or (4) acquired parasitic modes of life may cause a degeneration of appendages, and with it the disappearance of corresponding segments.

In discussing the body appendages it will be necessary to contrast those of the first anterior segment with all others. They consist of a single row of successive joints, whilst all the others divide into two branches, called biramous feet. Such a biramous foot is composed of three parts: the protopodite (basal), the entopodite (inner branch), and exopodite (outer branch). The protopodite consists of a proximal part, articulating with the body, and a distal part bearing the two branches, which are also segmented. Various modifications of the appendages arise all of which, however, may be traced back to the above type.

The body of the youngest Crustacean larva, the Nauplius larva, is unsegmented, possessing three constant pairs of appendages ( $\mathrm{r}$, pair simple feet; 2 and 3 , biramous). The anterior pair develops in the adult into the 
anterior antennæ, the second pair into the posterior antennæ, the third pair into the mandibles. During the metamorphosis (shedding of skin) of the Nauplius the larval body elongates and develops posteriorly new segments with new biramous appendages. In the adult the structure of these biramous feet may change.

The appendages of the head consist of the anterior antennæ (antennulæ), posterior antennæ, mandibles, anterior maxillæ and posterior maxillæ. The antennulæ are situated before the mouth, and consist only of one single row of joints (organs of touch, or smell, or hearing). The antennæ (feelers) consist typically of protopodite, entopodite and exopodite. The mandibles (or masticatory apparatus) are originally typical biramous feet; the basal joint of its protopodite is modified into a hard, often toothed plate; all other parts are reduced. The anterior maxillæ (masticatory) have retained more of the original character, an exopodite being frequently present. In the posterior maxillæ (masticatory) the exopodite is still further modified into a swinging plate. In the Thoracostraca, the Ostracoda and the Copepoda a pair of peculiar processes (paragnatha) arise between mandibles and maxillæ, which may be the free proximal joints of the anterior maxillæ.

The appendages of the trunk are divided into those of the thorax and those of the abdomen. Anterior thoracic feet may become auxiliary organs of nutrition (maxillipeds). In a complete thoracic foot of a Malacostracan an epipodite joins the proximal part of the protopodite, whilst the exopodite and the pentamerous entopodite are attached to the distal part. When exopodite and entopodite are wanting the thoracic foot is simple, representing a leg of seven joints in one row. When the 
proximal part fuses with the thoracic skeleton, only the distal part of the protopodite can be recognized. The abdominal feet (pleopods) are joined to the first six segments of the abdomen, whilst the seventh or last segment, the telson, is without appendages.

Respiration takes place through the external integuments, which in the higher forms undergo various modifications. The surface of theinteguments may be enlarged, forming a mantle or a dorsal shield, a bivalve shell or a cephalo-thoracic shield, whose soft parts aid respiration either as epipodial attachments of the maxillæ or of the maxillipeds, or as so-called branchial attachments of the fourth, fifth and sixth pair of appendages. In the higher Malacostraca the integumental reduplicature serves purely as a protection of the delicate gills. In the Balanidæ numerous mantle processes are generally considered as gills. In the Cyprididæ a series of gill-leaves occurs beneath the shell on either side of the dorsal line. The function of respiration is in the large majority of Crustacea carried on by the appendages or branches of the appendages, because the motions of the appendages and the consequent change of water is beneficial to respiration. (See classification for details.)

The body-epithelium is represented by the hypodermis which secretes a chitinous cuticula, serving as a protection for the body, and as an exoskeleton for the muscular structure. It undergoes in different individuals, in different places, manifold modifications, in some of them becoming calcified. Frequent molts further the growth of the body, and represent the metamorphosis of the Crustacea. Fine pores perforate the cuticula.

A connected cutaneous muscular envelope, characteristic in the Vermes, is wanting in all the Arthropoda. 
The exoskeleton offers a much larger localization of the muscular structure. There were evidently in the homonomously segmented ancestors of the Crustacea four longitudinal segmented muscles present, two dorsal and two ventral, with intersegmental myomeres. The muscular structure of living Crustacea may be divided into that of the body, of the appendages, and that which is common to both. The principles involved in the arrangement and work of the muscular structure of all the Arthropoda may be understood if we observe; (I) that the exoskeleton represents a chitinous tube in every seg. ment of the body and in every joint of the appendages; (2) that the muscles are attached to the internal wall of the skeleton; (3) that the muscles extend between the successive joints; (4) that the chitinons cuticular skeleton is thin and flexible between two segments or joints, and (5) that the tubiform exoskeleton of two successive segments or joints is connected hinge-like at opposite places.

When the muscular attachments to the exoskeleton are of a chitinous nature, an entoskeleton may arise. A shell muscle is present in the bivalve Entomostraca for the purpose of closing the shell. The muscular cells of all Arthropoda are cross-striped.

The alimentary canal extends as a simple straight tube through the whole length of the body. The mouth is situated on the ventral side of the head, distinguished by an overhanging upper lip and lower lip (paragnatha), and surrounded by appendages which have assumed the functions of mastication and prehension (mandibles, maxillæ, maxillipeds). The anus is situated in the terminal segment of the body. According to the ontogeny and structure, three separate parts of the alimentary 
canal must be distinguished: foregut, hindgut, and midgut, the last forming the long connection between the first and the second. Foregut and hindgut, arising from the ectodermal stomodæum and proctodæum of larva or embryo, possess on the internal surface of their epithelial wall a chitinous cuticula (intima) which continues at the mouth and anus into the hypodermal chitinous exoskeleton of the body. Only the epithelium of the midgut, derived from the mesenteron, is of entodermal origin. The midgut develops in almost all Crustacea diverticula which play the part of a hepato-pancreas. The foregut of the Entomostraca represents a simple œsophagus; that of the Malacostraca an ascending narrow œsophagus and an enlarged, cephalic masticatory stomach or crop. Salivary glands are generally absent in the œsophagus (except in Astacus fluviatilis), but present in the buccal cavity. The midgut of the Decapoda, Isopoda and probably the Anisopoda is almost entirely transformed into the hepato-pancreatic glandular tubes, so that the hindgut becomes very prominent in size. The anus of the Entomostraca is dorsally situated, that of the Malacostraca ventrally. Posterior glands or diverticula are wanting. Circular muscles control the contraction and expansion of almost the whole alimentary canal.

The nervous system of the Crustacea must be derived from that of the Annulata. Typically it consists of the brain or supra- œsophageal ganglion (two symmetriclateral halves in the first segment of the body-head-segment), which sends nerves to the unpaired eye, the anterior antennæ and the frontal sensory organs. All the other segments possess each two ganglia in the median ventral line (closely together or double ganglion). The țo 
ganglia of each segment are connected with each other by a transverse commissure, and with the corresponding ganglia of the neighboring segments by a longitudinal commissure. The two first commissures constitute the œsophageal commissures. From each double ganglion of the ventral cord nerves are given off to the muscles of the segment and its appendages, beginning with the second pair of antennæ. Modifications of this general structure (best represented in Phyllopoda) arise: (I) through a gradual fusion of the double ganglion into one; (2) through the close approach of the longitudinal commissure, which connect the ganglia; (3) through the close approach of successive ganglia which may fuse into a ganglion mass (Copepoda); (4) through the displacement of ganglia; (5) through the displacement of those regions which give off nerves; (6) entire disappearance of ganglia only takes place in the posterior ganglia. All these modifications are due to transformations in the whole organization. A sympathetic nervous system occurs in certain members of the Leptostraca, Arthrostraca and Thoracostraca. Nerves branch out from a ganglion on the upper side of the stomach, extending to the stomach wall, the liver, and the heart.

The eyes of the Crustacea are generally well developed, and exhibit a high degree of complication. Organs of vision are either wanting or rudimentary in most parasitic and sessile groups (Cirripedia), so among those which live in deep or dark regions. We distinguish two kinds of eyes: the unpaired frontal eye (secondary) and the paired lateral eyes (primary). The former occurs in the young larvæ of all Crustacea (Nauplius eye), and is retained in the adult Entomostraca; it evidently belongs to ancestral types. Paired eyes occur in all Malacos- 
traca and in many Entomostraca. They are either movable stalked eyes or rigid and sessile; the former are an outgrowth of the latter. They do not constitute a pair of appendages. (See structure of the eye, p. 57.) Specific organs of touch are the bristles of the antennæ and other appendages; one or two ganglion cells at their base are connected with the nervous system. Organs of smell are represented by special vesicles, threads, tubes or styles, grouped in tufts along the anterior antennæ. They are directly connected with nerve fibres (Calceoli of Amphipoda?) Frontal sensory organs are cuticular appendages innervated by the frontal nerves. They are present in the larvæ, and therefore of ancestral type. Auditory organs occur in the Decapoda at the basal joints of the antennulæ (page 53).

The blood-vascular system is not closed; it stands in open communication with blood-lacunæ, which are open cavities between the different organs of the body, representing the body cavity The typical plan of the system of circulation (nearest in Branchippus) is as follows: A contractile, tubular dorsal vessel (heart) traverses the body along the dorsal median line of the alimentary canal; flow of blood, as in Annulata, from the posterior to the anterior end. In each trunksegment a pair of slit-like openings, so-called ostia, lead from the dorsal ressel in the surrounding blood sinus, the pericardial sinus, which again represents a part of the body cavity. The hæmolymph flows from the latter into the dorsal ressel; leaving this at its anterior end, it traverses in reverse order the system of lacunæ, which extends beneath the integument of the body and its appendages, where respiration takes place, and returns again into the pericardial sinus. All other heart forms J* 
have arisen through reduction of segments and disappearance of ostia. (Details given in the classification.) The organs of respiration are in all Arthropoda interposed in that part of the blood circulation which returns the blood from the body to the heart. The blood corpuscles are generally colorless and of amœboid form.

The organs of excretion are chiefly represented by the shell gland and the antennular gland. Both are paired, the latter opening at the basal joints of the posterior antennæ, the former situated in the shell reduplicature or in the cephalo-thoracic shield, in the region originally corresponding to the second maxillary segment; it opens at or near the posterior maxillæ The antennular glands are present in the adult Malacostraca and the larval Entocostraca; the reverse is the case with the shell glands. The structure of both glands is essentially the same. A terminal vesicle (with lateral evaginations in higher forms) and loop-shaped urinary canal (with complicated coils and urinary vesicle in higher forms) compose these organs. Their origin is still doubtful.

The Crustacea are, with few exceptions, animals of separate sex. Only sessile and parasitic forms (Cirripedia and Isopoda) are hermaphrodites. Parthenogenesis occurs only in Estheria and Apus (Brachiopoda) and in the Cladoceræ. Male and female organs consist of one pair each, are of the same typical structure and occupy the same position in the body. The male organs are composed of the testes, vasa deferentia, ductus ejaculatorius and the apparatus of copulation; the female organs of ovaria, oviducts, receptaculum seminis (vulva, vagina), and an apparatus of copulation. Ovaria and testes can not be distinguished in their earliest stages; they arise as cell groups from the mesoderm, so likewise, but sepa- 
rate from them, the oviducts and vasa deferentia. The terminal portions are evaginations of the external integument. The external organs of copulation are either transformed appendages, or attachments of them, or processes, folds, humps, etc., of the integument.

Modifications of the sexual organs consist largely of fusions of the different parts. The ovaria and testes are either simple or branched or coiled tubes or sacs, situated dorsally on both sides of the alimentary canal, or between this and the heart, sometimes occupying the whole length of the body. The sexual apertures are on the ventral side (except in Copepoda and some Cladoceræ). The genital segment of the Entomostraca is not constant ; it generally lies immediately behind the anterior part of the trunk. The sexual apertures of the Malacostraca have a definite and constant position. Those of the male are situated at the basal joints (mostly) of the eighth pair of thoracic appendages; the female apertures at the basal joint of the protopodite of the antepenultimate pair of thoracic feet. The spermatozoa are often large, of radial shape, and immobile. Frequently spermatophores are present, and in the eggs accessory envelopes, both secreted by the glands of the eductory passages. Oviducts and vasa deferentia, together with the antennular and shell glands, are homologous with the nephridia of the Annulata.

Ontogeny of the Crustacea. The study of the metamorphosis of the Crustacea is one of the most interesting themes of morphological investigation. Having, however, given a full account of the ontogeny of the Annulata because of their central position, we have to confine ourselves to the most essential features. For a long time the Nauplius (larval form) was considered by the 
most prominent investigators the hypothetical ancestral form of all Crustacea and the Zoëa (larval) occupied the same position with regard to the higher Crustacea or Malacostraca. To Claus belongs the credit of having proved that the Zoëa is only a secondarily derived larval form, whilst Hatschek first pointed out that in the derivation of the Crustacea from Phyllopodal ancestors the relation of the latter to the Annulata would be the most natural explanation. He based his arguments especially upon the similar structure of the central nervous system, which represents a true homology. A derivation of Crustacea from an unsegmented Annelide through the Nauplius form, would argue for an independent origin of the corresponding features in both groups, i. e., a mere analogy, which can hardly be maintained. It is now acknowledged that the Nauplius is a segmented larval form (with three trunk-metameres, a cephalic region and an anal segment united with the budding zone) which may be compared with a young metamerical segmented Annelide larva. This shows that the larvæ of the Crustacea are trochophoræ secondarily modified by the early development of typical Crustacean characters. The transition of the Annulata to the ancestral forms of the Crustacea (Protostraca) was connected with certain changes in structure and mode of locomotion. But even this hypothetical form differs considerably from the Primitive Phyllopoda, the original, real Crustacea. The Palæostraca (Trilobita, Gigantostraca, Xiphosura) and the Pantopoda constitute the direct descendants of the Protostraca. Even Peripatus shows Crustacean characters, which proves that the ancestral form of Myriopoda and Insecta have their origin in the group of the Protostraca. The primitive Phyllopoda forming the transition 
from the Protostraca to the real Crustacea possessed evidently a more homonomously segmented body, and less difference in the various body regions than we find in modern Crustacea. Each trunk segment possessed a pair of ventral ganglia, a pair of biramous, lamellate, phyllopodlike appendages, and perhaps also a pair of nephridia (as in Peripatus). The forked processes of the anal segment may be likewise of ancestral origin. The most typical Crustacean characters evidently found their expression in the formation of the anterior body region, the so-called head, arising from a union of the first five anterior segments (sixth with eyes and frontal organs?), whose dorsal integument enlarged into a carapace. The originally uniserial antennulæ occupy an exceptional position as bearers of important sensory organs. The second antennæ were biramous and served as oars, or, perhaps, as masticatory organs. The basal joint of the mandibles assumed masticatory functions, whilst the rest is still retained in Copepoda as a biramous palpus. The two following pairs of maxillæ approached the structure of the trunk segments which they still possess in modern Crustacea. Paragnatha may also have been present. The first anterior cephalic segment contained the frontal organs (primary cephalic tentacle of Annulata?) the unpaired eye (so-called Nauplius eye) and the paired compound eyes. These are the characters which separate the real Crustacea from the Palæostraca and the other Arthropoda. The primitive Phyllopoda were probably of separate sex; they possessed a long dorsal vessel with paired segmental ostia and hepato-pancreatic diverticula.

In addition to what has been said on Peripatus, it must be emphasized that its muscular structure is repre- 
sented by a highly developed cutaneous muscular envelope, which consists: (I) of an external, circular, fibrous layer; (2) of a double layer of intersecting diagonal fibres; (3) of a strong, longitudinal, fibrous layer, composed of various lamina. Numerous sagittal or transverse muscular fibres constitute a median structure (around heart, alimentary canal and genital organs) and two lateral structures (around nervous system and segmental organs). They correspond to the dorso-ventral or transverse muscle fibres of the Annulata. Only the muscles of the jaws are cross striped. The alimentary canal (ciliated internally) extends through the whole body, and consists of mouth-cavity (with opening of salivary glands), pharynx (with very thick muscular wall), short œsophagus, stomach (with folded wall but without mesenteries) and rectum. The nervous system is distinguished by the numerous transverse commissures (9-1o in one segment), which connect the widely separated longitudinal nerve cords. Two nerves proceding from the brain to tongue, pharynx and œsophagus, represent a sympathetic nervous system. The two dorsal cephalic eyes correspond in their structure to the eyes of Alciopea. Ontogenetically it is an invagination of the cephalic ectoderm. The blood-vascular system of Peripatus is typical; the pericardial sinus is separated from the body cavity beneath by a horizonal, perforated septum. Every segment possess a pair of mephridia which exhibit the typical structure of those of the Annulata. Salivary glands, anal glands and genital ducts are modified nephridia. Of extraordinary importance is the fact that Peripatus possesses the respiratory organs which are characteristic only of the Tracheata, namely trachea or air tubes. They consist of very long and thin 
chitinous tubes which united into tufts open at the base of flask-shaped depressions of the integument. Their number and arrangement vary. Coxal glands are present in all appendages except the first pair. They are very long in the male. The above-mentioned salivary glands are transformed coxal glands extending through the body. The sexes are separate. The female apparatus consists of ovaria (attached to pericardial septum), uteri (much coiled), unpaired vagina (ventrally between penultimate legs); receptaculum seminis and receptaculum ovorum, each one attached to an uterus. The male apparatus consists of testes, vasa efferentia, seminal vesicles, vasa deferentia (much coiled) and ductus ejaculatorius, which secretes a spermatophore. Peripatus is viviparous. The eggs develop in the uterus, in which all stages are found, the youngest nearest the ovarium, the oldest nearest the vagina.

The anatomic and ontogenetic relations show that Peripatus unites the characteristics of the Annulata and the Arthropoda, although those of the latter preponderate. Phylogenetically it must be considered as the central link of a chain which begins, with the Annulata and ends with the Insects. The Annelid characters of Peripatus are: the segmental nephridia, the segmental coxal glands, (setal glands of Chætopoda), and the cutaneous muscular envelope; the Arthropodal characters are: the tracheæ, the dorsal vessel and the lacunar system of circulation, the transformation of appendages into mouth parts (jaws), and the specific form of the salivary glands.

Antennata. The body of the Myriopoda consists of the head and a large number of equally developed trunk segments, the three anterior of which correspond to the three thoracic segments of the Hexapoda. The head is 
the result of a fusion of at least four segments. The typical Antennate form Symphyla consists of twelve distinct segments with ambulatory appendages and of an anal segment with two processes called spinning styles. The two preanal apparatuses of touch may indicate the transformed feet of a thirteenth segment, so that the whole number of segments corresponds to the original number of the hexapodal segments. In the Pauropoda there are only ten trunk segments, whilst in the Chilopoda and Diplopoda there are many more (secondarily acquired). The body of the Hexapoda is divided into three distinct regions ; the unsegmented head (originally four segments), the thorax, consisting of prothorax, mesothorax and metathorax and the abdomen with ten or eleven segments; the winged insects have generally less than ten, owing to the fusion of either the penultimate or the first abdominal segments. In Macrolepidoptera, Diptera and Rhynchota the third thoracic segment approaches more closely the abdomen. The appendages of the insects consist of a single series of joints. We distinguish between the appendages of the head and those of the trunk. In the trunk only the three pairs of thoracic appendages are retained (rudiments of abdominal appendages occur) The appendages of the head are typically composed of four pair: antenna, mandibles, anterior and posterior maxilla. There is only one pair of preoral frontal antennæ present, which vary greatly in form (in different sexes), and perform the functions of organs of touch and smell.

The mouth appendages vary greatly according to their functions, but they can all be traced back to the mandibles, and the maxillæ. The upper lip or labrum is a single piece and has nothing to do with the appendages, 
the mandibles (upper jaw) consist each of a strong but unsegmented masticatory plate with toothed margin. The anterior maxilla (lower jaw) consist each of a two-jointed basal part with five jointed palpus and two unsegmented jaws (mala externa and interna). The posterior maxilla form together the labium or underlip; each one consists of a basal joint, a three-jointed palpus, and an external and internal jaw; the basal joints have fused behind and beneath the mouth. There are numerous modifications which are indicated in the classification. The appendages of the trunk assume manifold forms according to the various functions of walking, jumping, swimming, preying, etc. (Details in the classification.) Wings are entirely wanting in the Myriopoda. The wingless condition of the Apterygota is typical as in the Myriopoda and Protracheata. Two pairs of wings represent the typical condition of the Pterygota, which may all be derived from a common ancestral winged group. The wings are appendages of the meso- and meta-thorax, being thin, lamellous, unsegmented reduplicatures of the body wall, especially of the integument. They are venate, and provided with nerves, branched tracheæ and blood canals. The arrangement of these veins is of great importance for phylogeny and classification. The explanation of the origin of the wings is still a matter of conjecture. The integument and muscular structure are in the main the same as in the Crustacea. To be mentioned are especially the variation of integumental glands and the muscles of flight in the thorax. The alimentary canal of the Myriopoda and Apterygota extends as a straight tube through the body; in the winged insects it is more or less coiled. It consists in all cases of the distinct foregut (from the ectodermal 
stomodæum), the entodermal midgut and the hindgut (from the ectodermal proctodæum). Especially characteristic for most of the insects are the thread-or tubeshaped diverticula of the hindgut, which perform functions of excretion, and are known as the Malpighian vessels. Their large epithelial cells (with branched nuclei) contain urinary concretions. Sometimes they only consist of a few rows of cells. Their number is indefinite. The nervous system is essentially the same as that of the Crustacea, also the same modifications occur within different orders. Ocelli and compound eyes occur either together or separate. The ocelli of the Myriopoda are generally situated on the dorsal side of the head; the larvæ of the Hexapoda possess only ocelli, the adults show generally ocelli between the facetted eye. (See classification.) The structure of the compound eye is essentially the same as that of the Crustacean eye. They are divided into eucone and acone eyes (see pages 57-59). The structure of the ocelli of the Dytiscus larvæ and other insects and Myriopoda is worthy of special notice. It consists of a chitinous lens, beneath a hypodermal papilla whose basal cells form the retina; each retinal cell is connected with a nerve fibre, containing pigment and continuing externally into a rod; the cells along the margin of the papilla are free from pigment and form a glasslike body between retina and lens. On auditory organs see page 54 . On the organs of smell, page 52 . The system of blood circulation is very simple in the Antennata. The contractile dorsal vessel (heart) is divided into successive segmental chambers (eight or nine) provided with valves which prevent the return of the blood from the anterior to the posterior chambers. Intersegmental paired ostia form an open communication between the 
body cavity and the interior of the heart. Triangular wing muscles (constant) are fastened with their broad end to the heart chambers, and constitute an incomplete horizontal partition wall, above the alimentary canal, thus aiding in the formation of a pericardial sinus. The heart is posteriorly blind, but continues anteriorly into an aorta which empties the blood into the lacunæ of the body. Sometimes a ventral sinus is present, in which the flow of the blood is the reverse (also a heart nerve). A mass of large fat globules constitute the so-called fat body, which represents the nutritive reserve fund in metamorphosis and reproduction. The luminous organ of certain beetles is a differentiation of the fat body undergoing oxydation.

The organs of respiration are air-tubes or trachea, either opening to the outside by paired, strictly segmental, external apertures (stigmata) or anastomosing throughout the whole body and its appendages. The structure of the tracheæ is everywhere essentially the same; it is internally lined by a chitinous intima (a continuation of the external chitinous integument) which ends in a spiral thread to keep the air-tube open. An external cell layer, which secretes the intima, is a continuation of the exter. nal hypodermis. The modifications of the stigmata are manifold, adapted to the requirements for protection. The number of tracheæ was originally the same as that of the segments, but reduction has greatly changed this condition. Respiration is bronght about by the contraction and expansion of the abdomen. Tracheal gills occur in the aquatic larvæ of the insects. They are either external (Odonata), consisting of three foliaceous gills on ,the last abdominal segment or they are internal (Libellula, Eschna), representing folds of the rectum. Other larval 
gills are of various form and position. All these larvæ are apneustic. The gills disappear with the larval stage, except in the Perlidæ, Eischnidæ, Sialidæ, Lepidoptera, and Coleoptera.

Special sounds are reproduced by certain insects, either by rapid movements of the wings, or of foliaceous trachæal appendages (Hymenoptera, Diptera), or by the friction of uneven parts of the integument (Acridiidæ, Gryllidæ), or by special drum apparatuses in the first abdominal segment (Cicadæ).

All Antennata are of separate sex. The sexual organs are essentially the same as those of the Crustacea. In Peripatus the larger portion of the ducts is of ectodermal, in the Antennata of mesodermal origin. Exclusively paired sexual organs occur, however, only in the Ephemeridæ; in all other Antennata, fusions take place in various ways. The germ glands unite in the Myriopoda and Diplopoda; unpaired terminal portions arise in all Antennata, except in the Ephemeridæ and Diplopoda. Accessory sexual apparatus occur either as evaginations of the ductus ejaculatorius or of the paired vasa deferentia, when they become (unpaired or paired) vesicula seminalis; accessory glands may secrete spermatophores. The terminal apparatus is often a protrusible penis; in the female it constitutes the bursa copulativa and the receptaculum seminis. They frequently open near the anus in a common cloaca. Special modifications of the last abdominal segments become parts of the sexual apparatus as ovipositors, stylets, etc. In most Diplopoda the legs of the seventh abdominal segment assume copulatory functions.

Sexual dimorphism manifests itself in broad differences of male and female forms. The females of the Coccidæ, 
and Lampyridæ, of Psyche and Orgyia are without wings. The females of the parasitic Strepsiptera are viviparous, but remain maggot-like in the abdomen of their hosts. Polymorphism occurs in insects which form communities (bees, ants, white ants).

Ontogeny of the Antennata. The embryonic development of the Insects takes place within the egg. The organism which leaves the egg possesses the typical structure of an Insect, namely a segmented body, antennæ, mouth-apparatus, thoracis appendages, developed nervous, digestive and trachæal systems, the dorsal vessel, the muscular structure, etc. It moves and feeds freely. It is called a larva. The larvæ of the Insects are, therefore, much more highly developed than those of most other invertebrate animals. The factors which condition the numerous changes which an insect larva undergoes before it reaches the adult stage (imago) are principally the degree of deviation from the original insect form and the difference in the habitat of larvæ and imagines. Where development takes place without metamorphosis (ametabolism of Apterygota) there is no difference between larva and imago, except that the sexual organs are not fully matured in the young animal. In cases of gradual metamorphosis the larva gradually develops wings by numerous molts of the integument (Orthoptera, Corrodentia, Thysanoptera, most Rhynchota). The larvæ of the Cicada live in the earth, their imagines upon trees and bushes. In the transition a transformation of the anterior legs takes place which necessitates an intermediate stage, the pupa, so that we have a gradual metamorphosis with pupa stage. The larvæ of the Ephemeridæ, Odonata and Plecoptera live in water, their imagines on land; during the transition the tracheal gills mostly disappear 
and a holopneustic system of tracheæ arises very gradually; here incomplete metamorphosis (hemimetabolism) takes place. In all these cases the larvæ appear at first without wings; in some species of the Plerygota wings are never developed (reduction or acquired ametabolism). All other Insects undergo complete metamorphosis (holometabolism). The larvæ do not change at all, but pass over into the pupa stage, which is mostly quiescent. The pupæ are very differently formed, often distinctly segmented with closely packed appendages and rudimentary wings, often with concealed appendages. When they are unable to procure food they are protected by special envelopes (e. g., cocoons). At the end of the pupa stage the envelope opens and the imago escapes. Complete metamorphosis arose from incomplete metamorphosis through the suppression of the frequent molts of the integument. These larvæ are divided into two groups, those with feet (Neuroptera, Lepidoptera, Coleoptera, Trichoptera), and those without feet (apodal maggot-like Diptera, most Hymenoptera and Siphonaptera). The mode of living of these larvæ varies greatly; they are originally all peripneustic, but become by adaptation amphipneustic, metapneustic, and even apneustic, developing gills. Their mouth apparatuses may also be very different from those of the imago (Lepidoptera). A great many modifications of the normal conditions occur (Apis, Sitaris, Pteromalidæ). Internal metamorphosis manifests itself in the gradual development of the imago organs from corresponding larval organs, which gradually disintegrate and disappear (function of phagocytæ) The embryonic development of the Insects (p. 40) differs . from that of the Myriopoda in the formation of the amnion (internal) and the serosa envelope, an epithelial mem- 
brane surrounding the whole egg. Both, however, have no part in the upbuilding of the embryo. The Myriopoda undergo a partial metamorphosis, inasmuch as the posterior segments in some larval forms (Scutigeridæ, Lithobiidæ, Chilopoda) increase until the required number of the respective imago is reached; the body differentiates from the anterior towards the posterior end (not observed in the Insects).

The peculiar cases of parthenogenesis in certain Lepidoptera and others, of heterogeny in the Aphides and Chermes abietes, and of padogenesis in Cecidomyia, deserve special mention.

Phylogenetically the Insecta and Myriopoda are closely related, the Symphyla and Thysaneura forming the transition groups from the latter to the former, whilst the Myriopoda exhibit a close resemblance to Peripatus, so that Onychophora, Myriopoda and Insecta represent a phylogenetic series, which in Peripatus joins the hypothetic ancestral type of the Arthropoda (Protostraca) and through that the Annulata.

Arachnoidea. The first seven (?) anterior segments unite into a cepalo-thorax (mostly unsegmented).

The abdomen generally consists of a variable number of separate or fused segments, but it may itself fuse with the cephalo thorax (Acarina, Iinguatulicæ) into one uniform structure. Thus a gradual concentration of the whole body is observed in the Arachnoidea. The Scorpionidæ and Solpugidæ, representing the transition groups, possess the largest number of segments. The cephalo-thorax of the latter is divided into an anterior, unsegmented region, the head (resembling the Antennata), and into a posterior region, the thorax, consisting of three segments (as in the Antennata); this is followed 
by the abdomen with ten segments. The cephalo-thorax of the Scorpionidæ is only segmented (seven) in the embryo. (See classification.) The Arachnoidea are typically provided with six pairs of appendages which belong exclusively to the cephalo-thorax. The abdomen is always without appendages. The first pair of appendages, the Chelicerae (mandibles, maxillary antennæ, chelate antennæ), is situated above and before the mouth. They are either three or. two-jointed. They are chelate when the claw-like terminal joint can be moved against a process of the preceding joint (Scorpions, many Acarina), or sub-chelate when the last joint is folded down upon the next like the blade of a pocket-knife (Spiders). The second pair of appendages, the pedipalpi or maxille are situated on both sides of the mouth, and mostly perform the function of jaws. They consist of a stout basal-joint and a segmented palp, which may serve as organ of touch or acquire the form and segmentation of a leg. This either ends with or without a claw, or with a chela, and performs functions of prehension, or locomotion or copulation (see classification). The other four pairs of appendages are mostly of similar structure (six-jointed), and serve as organs of locomotion (third and fourth pair modified in Scorpions, so the third in Pedipalpi)

The nervous system corresponds to the segmentation of the body, tending towards concentration. The brain is connected with the ventral cord by a short osophageal commissure and innervates the cheliceræ (different in Phalangidæ and Gamasidæ) and the eyes. Its ontogeny shows that it has fused with the first postoral ganglion pair of the embryo, which would indicate that the cheliceræ are homologous with the mandibles of the Anten- 
neta. The ganglia of the cephalo-thorax fuse together with a number of abdominal ganglia into a large thoracic ganglion mass, which sends nerves to the other five pairs of appendages and to the anterior abdominal segments; the number of abdominal ganglia varies. The whole central nervous system of the dipneumonous Araneidea and of the Acarina is represented by one single fused nerve mass, perforated by the œsophagus and sending out radiating nerves. Most Arachnoidea possess eyes which are uniconical and of the same structure as the ocelli of the Antenneta. They are sessile, their number varying from two to twelve, symmetrically arranged upon the upper side of the cephalo-thorax. The structure of the median eyes of Scorpionide corresponds to the ocellus in the possession of a singular cuticular corneal lens and to the facetted eye, inasmuch as its retina-cells are arranged in groups, as so-called retinulæ.

There are numerous glands opening on the external integument of the Arachnoidea. The spinning glands of the Araneidea open by spinning mammillæ (rudimentary abdominal appendages); preceding them is the so called cribrellum, a paired glandular region with numerous openings. There are also similar glands in other appendages of the body (coxal glands, spinning glands, protrusible vesicles and the poison glands of the Araneidea). A great many cuticular glands (so the poison gland of the Scorpion) occur in almost all Arachnoidea. The alimentary canal consists of foregut (pharynx and œsophagus, the latter widening into the sucking stomach of the Araneidea), large midgut with blind diverticula (chylus stomach) and short hindgut into which tubular organs of excretion open, corresponding to the Malpighian tubes of the Antennata. The blood-vascular system re- 
sembles that of the Antennata (highest in Scorpionidea and Araneidea). The heart varies from the large, manychambered dorsal vessel to the one-chambered heart sac of some mites. A pericardium is only rarely present. The most constant part is the aorta cephalica, a remnant of an original anterior part of the dorsal vessel. The heart of all Arachnoidea is situated in the abdomen. The organs of respiration are trachece whose external openings or stigmata ( $\mathrm{I}-4$ pairs) are almost exclusively situated on the anterior ventral part of the abdomen. They are tubular trachece (corresponding to those of the Antennata) or fan trachea, generally called lungs, lungtracheæ, lung sacs or foliaceous tracheæ (belonging exclusively to the Arachnoidea). Three modifications of the tubular tracheæ occur. The chief branch proceding from the stigma may divide into many branches (Solpugidæ, Cyphophthalmidæ, Phalangidæ, Pseudoscorpiondæ, Gamasidæ, Ixodes), or only in two (Araneidea, Acarinæs), or it may be wanting altogether, the tracheal tubes proceeding directly from the stigma (Chernes cimicoides). The fan trachea consist of hollow lamellæ placed upon one another in great number like the leaves of a book, and connected together by trabecul so as to have the form of a sac. They are always kept open by a firm internal chitinous membrane, so that the air can enter by the stigmata at the beginning of the abdomen and be distributed to the finest ramifications.

All Arachnoidea are of separate sexes. The structure of the sexual organs varies greatly. The male organs consist of paired testicular tubes, and the vasa deferentia often receive the contents of accessory glands before opening to the exterior by a single or double aperture at the base of the abdomen. Special coptulatory organs in 
the region of the genital openings are, as a rule, wanting, but appendages, far removed from the genital openings, often serve to transfer the sperm from the male to the female. The female sexual organs are also paired, generally racemose glands, with two oviducts, which usually dilate into a receptaculum seminis before their single or double opening at the beginning of the abdomen. They are also connected with accessory glands; a protrusible ovipositor is rarely present. Only a few of the Arachnoidea are viviparous (Scorpions and some Mites); the greater number lay eggs which they sometimes carry with them till they are hatched. The embryonic development exhibits a much more numerous metameric segmentation than we find in the adult animal. The serosa and amnion membranes have only been observed in the Scorpions. The newly-hatched young have the form of the adult. Only in the Pseudoscorpionidæ and the Acarina a post-embryonic metamorphosis occurs (very complicated in Pygnogonida, Pentastomida and Hydrachnea-water mites).

It is highly probable that the Arachnoidea arose together with the Palæostraca from lower ancestral forms, but afterwards branched off, while the other Tracheata belong to another stem which is connected with that of the Arachnoidea at the base. 


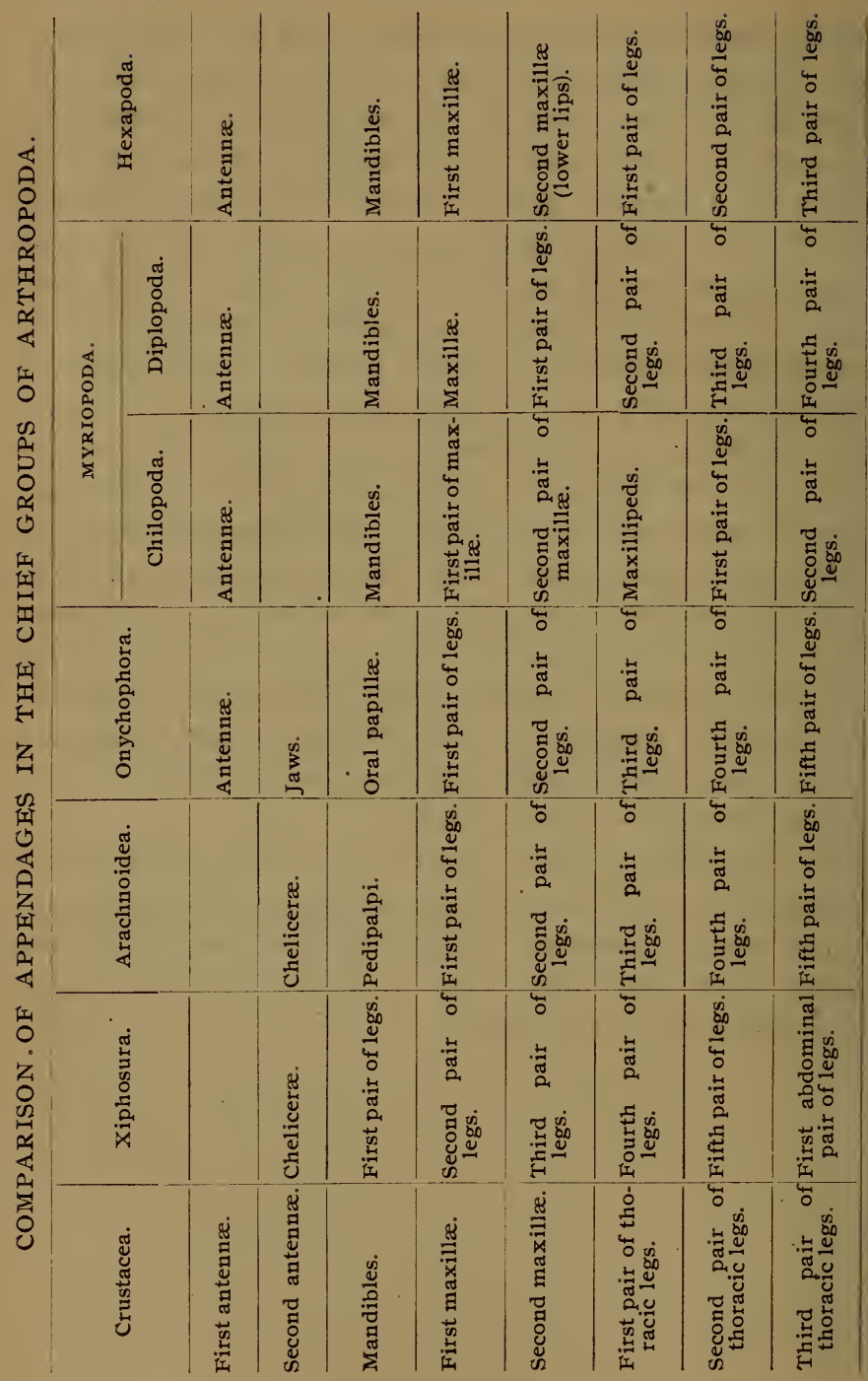




\section{MOLLUSCA.}

Originally bilaterally symmetrical animals with unsegmented body. The dermal muscular structure of the lower, i. e., ventral surface, is greatly developed, and gives rise to a more or less projecting locomotory organ of very various shape, the foot. A reduplicature of the body wall forms a circular fold, the mantle which hangs over the mantle cavity. This cavity is originally most spacious at the posterior end, where it contains the two gills, symmetrically grouped on both sides of the median anus, the two nephridial openings and the sexual apertures. The dorsal portion usually develops into a visceral sac and is protected by a shell which extends to the edge of the mantle. The mouth is situated in the anterior region of the body and leads into a pharynx mostly provided with jaws and a hard chitinous plate, the radula. The midgut contains a voluminous digestive gland (liver.) The secondary body cavity is reduced, but always constitutes the pericardium. The bloodvascular system is open, largely lacunar; the heart dorsal, originally with two symmetrical auricles, arterial. Nephridia originally paired, in open communication with the pericardium. The central nervous system consists of the paired cerebral, pleural, pedal and visceral ganglia. Of separate sexes or hermaphrodites. Gonads mostly unpaired, with paired or unpaired ducts. A modified trochophora arises from the gastrula, the characteristic Mollusscan veliger larva. 
This short general characteristic has to be modified for each class. Shell, mantle, gills, foot and oral armature may disappear, and a displacement of the mantle organs may produce a far-reaching symmetry.

I CLASS: Amphineura. Bilaterally symmmetrical Molluscs. The nervous system usually consists of two lateral and two ventral cords, connected by numerous commissures and supplied with ganglion cells; they join anteriorly the cerebral ganglion. Special sensory organs reduced. Marine.

I. Order: Placophora sive Chitonida. Eight calcareous plates, arranged successively like the tiles of a roof, cover the dorsal side. Separate cephalic region with mouth. Numerous gills on either side, in the furrow between the foot and the mantle zone. Foot (except in Chitonellus) strongly developed, with large, flat sole, adapted for crawling or clasping. Paired genital ducts and paired nephridia. Of separate sexes. Heart with two auricles. Radula $(3+\mathrm{I}),(2+\mathrm{I}),(\mathrm{I}+\mathrm{I}+\mathrm{I}),(\mathrm{I}+2),(\mathrm{I}+3)$. Chiton. Chitonellus.

2. Order: Aplacophora sive Solenogastres. Body almost cylindrical, usually worm-shaped. No shells. Calcareous spicules are embedded in the dense cuticula. Foot rudimentary. Mantle cavity reduced to a furrow on both sides of the rudimentary, septate foot, and a cavity (cloaca) at the posterior end, into which alimentary canal and nephridia open and where the rudimentary gills are situated, whenever such are present. The nephridia serve as genital ducts.

I. Family: Neomeniida. Foot a longitudinal septum arising at the bottom of a medio-ventral longitudinal furrow. Hermaphrodites. Proneomenia. Neomenia. Lep. idomenia. Dondersia. 2. Family: Chatodermida. Foot 
and foot-furrow entirely reduced; sexes separate. Chatoderma.

II CLASS: Gasteropoda(Cephalophora). Snails. Body asymmetrical. Head, bearing tentacles and eyes, usually distinct from the body. Foot well developed, in most cases adapted for crawling. The large visceral sac tapers gradually and is usually spirally twisted (may disappear secondarily); it is covered by a single shell (case) into which the animal can withdraw. Wherever a secondary reduction of the visceral cavity takes place the shell may become rudimentary or disappear altogether (rarely in the Prosobranchia). Mantle-complexus upon the right (rarely left) side or moved (along this side) towards the anterior end. Visceral sac and shell spirally twisted. Asymmetry manifests itself in all groups (except the lowest Prosobranchia) in the disappearance of one gill, of one nephridial organ and of one auricle.

I. Order: Prosobranchia. Pleuro-visceral connective cross-striped. Mantle-complexus at the anterior region of the visceral sac. On most forms only one gill before the heart. Auricle before the ventricle. Animals of separate sexes, largely marine. Foot usually with operculum (cover) to close the shell. Only Titiscania without shell.

I. Suborder: Diotocardia. Heart with two auricles (excl. Docoglossa). Two nephridial organs. Two ganglionic longitudinal nerve cords in the foot, connected by numerous transverse commissures. Gills of pectinate form (double row) apex projecting freely. Epipodium well developed; a circle of tentacles, varying in number, around the base. Without proboscis, penis and sipho.

a. Zengobranchia (Rhipidoglossa. Aspidobranchia). Two gills, both auricles well developed. Heart perforated by 
the rectum. Shell with marginal slit, or with apical aperture, or perforated by a row of holes. Usually without operculum. Marine. Family: Haliotide, radula $\infty$ I. (5. I. 5.) I. $\infty$. Fissurellide : Fissurella, rad. $\infty$ I. (4. I. 4.) I. $\infty$, with secondarily symmetrical shell. Emarginula. Scutum (Parmophorus.) Pleurotomarida: Pleurotomaria. Scissurella. Polytremaria. Bellerophontida, fossi1.

b. Azygobranchia. One gill, the left of the Zeugobranchia. Right auricle a blind diverticulum. Heart perforated by the rectum. Family: Turbonide, rad. $\infty$ o. (5. I. 5.) o. $\infty$. Trochide. Stomatiida. Neritopsida, rad. $\infty$ I. (2. o. 2.) I. $\infty$, marine. Neritide, rad. $\infty$ I. (3. I. 3.) I. $\infty$, marine, are capable of living out of water along the coast. Neritina, fresh water forms. Hydroconida, rad. $\infty \mathrm{I}$. (I. I. I.) I. $\infty$, and Helicinidce, $\infty$ I. (4. I. 4.) I. $\infty$, are both without gills, and possess a lung similar to that of Pulmonata. The Helicinidæ are terrestrial.

c. Docoglossa. Heart with one auricle, not perforated by the rectum. Left nephridial organ moved to the right of the pericardium. Visceral sac and shell secondarily symmetrical, the latter usually cup-shaped. Operculum wanting. Marine.

I. Left true gill (Ctenidium) present. Acmaceda, rad. I. 2. (I. O. I.) 2. I, with numerous accessory gills in the mantle furrow: Scurria; without such gills: Acmea (Tectura).

2. True gills (Ctenidia) wanting altogether, accessory gills present in large numbers in the mantle furrow. Family: Patellide, rad. 3. I. (2. o. 2.) I. 3. 3. Without ctenidia and accessory gills. Lepetidce; rad. 2. o. I. o. 2.

2. Suborder: Monotocardia (Pectinibranchia.) Heart with one auricle. One single true gill, of pectinate 
form (single row), its apex not freely projecting (exc. Valvata). Usually pedal ganglia, rarely pedal cords. One nephridial organ. Sipho and penis present in most cases. Epipodium feebly developed or wanting. Largely marine snails of very variable shape.

a. Architcnioglossa. Pedal cords. In Cypræa (and other forms) a rudiment of the right auricle still present. Family: Cypreidce, rad. 3. I. I. I. 3. Paludinida (fresh water). Cyclophoridae (terrestrial, with lungs).

b. Tenioglossa. Typical radula 2. I. I. I. 2. Semiproboscidifera: Families: Naticidæ. I amellaridæ. Rostrifera: Families: Valvatidæ (fresh water). Ampullaridæ (fresh water). Littorinidæ. Cyclostomidæ (terrestrial). Planaxidæ. Hydrobiidæ (fresh water). Aciculidæ (terrestrial). Truncatellidæ (partly terrestrial). Hypponycidæ. Capulidæ. Calyptræidæ. Pseudomelanidæ. Melanidæ. Cerithiidæ. Vermetidæ. Turritellidæ. Xenophoridæ. Struthiolaridæ. Chenopidæ. Strombidæ. Proboscidifera holostomata. . Families: Scalaridæ, rad. n, O, n. Solaridæ, rad. n, O, n. Pyramidellidæ, rad. O. Eulimidæ, rad. O. Proboscifera siphonostomata. Families: Colombellinidæ. Tritoniidæ. Cassidiidæ. Doliidæ. Ianthinide, rad. n, O, n. Heteropoda, (pe1agic Tænioglossa with fin-like foot (perpendicular). Families: Atlantida. Pterotracheida.

c. Stenoglossa. Normal rad. I. I. I. Rachiglossa. Families: Turbinellidæ. Fusidæ. Mitridæ. Buccinidæ. Muricidæ. Purpuridæ. Haliadeæ. Cancellaridæ. Volutidæ. Olividæ. Marginellidæ. Harpidæ. Toxiglossa. Families: Pleurotomidæ. Terebridæ. Conidæ.

2. Order: Pulmonata (Lung-snails). Pleuro-visceral connective, not cruciform. Gill displaced by a respiratory vascular network on the interior surface of the mantle $\mathrm{K}^{*}$ 
(lung). Pallial complexus originally on the anterior right side of the visceral sac. Margin of the mantle fused with the cervical integument, leaving only a respiratory aperture on the right side. Visceral sac and shell frequently rudimentary in terrestrial forms (night snails). Operculum usually wanting. Heart with one auricle, generally in front of the ventricle. Hermaphrodites with hermaphroditic gland and complicated eductory apparatus. Terrestrial and fresh water animals.

I. Suborder: Basommatophora (fresh-water forms). Eyes at the base of the ocular tentacles (not invaginable). Sexual apertures separate on the right anterior region, male in front of female. Family: Limnaide. Limnæa. Amphipeplea. Physa. Planorbis. Ancylus. Auriculide.

2. Suborder: Stylommatophora. Eyes at the apex of the ocular tentacles. Tentacles invaginable.

a Monogonopora. With a single sexual aperture (to the right). Family: Helicide. Helix. Arion. Bulimus. Testacellida: Daudebardia. Testacella. Limacide: Ariophanta. Limax. Vitrina. Zonites. Helicarion. Bulimulida. Pupida. Buliminus. Pupa. Clausilia. Succineida.

b Digonopora. Nocturnal snails with separate male and female sexual apertures. Both on the right side, male at the anterior, female at the posterior end. Palleal complexus at the posterior region, lung-cavity reduced. Families: Vaginulida (terrestrial). Oncidiidæ (marine or amphibious), respiration partly through respiratory dorsal appendages.

3. Order: Ophistobranchiata. Pleuro-visceral connection not cruciform. One auricle behind the ventricle. Hermaphrodites. Shell present or (more frequently) 
wanting. Operculum usually wanting. Respiration by genuine ctenidia or adaptive gills or by the integument. Visceral sac very often reduced. Hermaphrodites with hermaphroditic gland. Marine.

I. Suborder: Tectibranchiata. Pallial complexus on the right side, more or less covered by the mantle fold. Always one gill (originally the left) present, only incompletely covered by the mantle. Visceral sac tending to reduction. Shell always present, tending to become rudimentary. Usually with parapodia and mantle lobes covering the shell.

I. Reptantia: (a) Cephalaspidea, with frontal disc. Families: Actconida (with operculum). Scaphandrida. Bullide: Bulla. Acera. Gasteropterida. Philinida. Doridiida. (b) Anaspidea. Head without frontal disc. Four lobe-like or auricular tentacles. Family: Aplysiide. Aplysia. Dolabella. Notarchus. (c) Notaspidea. Head short, with or without tentacles. Dorsal region forms a large disc (notæum) upon which a shell may lie. Families: Pleurobranchida: Pleurobranchus. Pleurobranchæa. Oscanius. Umbrellida: Umbrella. Tylodina. Peltida.

II. Natantia sive Pteropoda (fin-snails). This group constituted formerly a special class of Mollusca, but is now classified as Tetrabranchiata, adapted to the free swimming pelagic mode of life. The parapodia of the Tectibranchia are developed into fins or wing shaped swimming organs. (a) Pteropoda thecosomata. Shelled fin-snails. More closely related to the Cephalaspidea. Mantle, mantle-cavity, shell present. Head not distinct. Only one pair of tentacles. Fins fused along their anterior margin above the mouth. Anus on the left side. Families: Limacinide. External calcareous shell twisted 
to the left with a spiral operculum. Anus on the right side. Limacina. Peraclis. Family: Cavoliniida. External calcareous shell symmetrical. Clio. Cavolinia. Family: Cymbuliida. Internal cartilaginous shell. Cymbulia. Cymbuliopsis. Gleba. The Thecosomata feed largely on small Protozoa and Algæ. (b) Pteropoda gy'mnosomata. Naked fin-snails. They are more closely related to the Anaspidea. Without mantle, mantle cavity and shell. Head distinct. Two pairs of tentacles. Fins separate. Anus on the right side. Family: Pneumodermatide. Ctenidium on the right side. Dexiobranchæa. Spongiobranchæa. Pneumoderma. In the two last genera an additional adaptive posterior-gill. Families: Clionopsida and Notobranchcida. No Ctenidium. An adaptive posterior gill. Family: Clionida. Neither ctenidium nor adaptive gills present. All Gymnosomata are predatory, feeding largely on Thecosomata.

2. Suborder: Ascoglosea. The used up teeth of the long and narrow radula (consisting of a single row of plates) preserved in a pouch at the anterior end of the radula. No jaws. Anus almost always dorsal. Ctenidium, mantle and mantle cavity absent (except in Steganobranchia).

I. Section: Steganobranchia. With mantle on the right side, mantle cavity, ctenidium, shell and parapodia. Family: Oxynoidece: Oxynoe. Lobiger.

2. Section: Cirrobranchia. Along the sides of the dorsal region foliacious or club-shaped processes. Families: Hermaida. Phyllobranchida.

3. Section: Pterobranchia. Lateral parts of the body drawn out into lobes. The branches of the midgut gland (liver) extend into these lobes. Families: Elysiada. Placobranchida. 
4. Section: Abranchia. Neither ctenidium, nor dorsal appendages, nor foliacious lateral extensions of the body. Integumental respiration. Body almost planaria-like. Family: Limapontiida.

3. Suborder: Nudibranchia. Without mantle fold, shell and ctenidium. Jaws usually present. Radula mostly well developed, with teeth which may disappear, Adaptive gills very variably developed, sometimes $\mathrm{O}$.

I. Section: Holohepatica. A large compact (unbranched) digestive gland (liver.) Numerous gill lamellæ in a furrow around the body. Without jaw and radula. Pharynx transformed into a suctorial apparatus. Cells form a rosette around the dorsal anus. Doridida cryptobranchiatce. With gill-rosette around the dorsal anus, retractable into a cavity. Bathydoris. Archidoris. Discodoris. Dianlula. Kentrodoris. Platydoris. Chromodoris, etc. Doridida phanerobranchiata. Gill-rosette not retractable. Goniodoris. Polycera. Acanthodoris. Atalia. Ancula. Euplocamus. Triopa, etc.

2. Section: Cladohepatica. Liver entirely or partly dissolved into branched, separate canals, extending far into the body. Dorsal appendages of various form usually with respiratory functions. Anus usually on the right side. Families: Eolidiadce: Eolidea. Berghia. Tergipes. Galvina. Coryptella. Rizzolia. Facellina. Flabellina. Fiona. Glaucus. Janus. Hero. Tethymelibida, without radula: Tethys. Melibe. Lomanotida. Dotonida. Dendronotida. Bornellida. Scyllaidce. Phyllirhoida. Pelagic free swimming animals, with narrow laterally compressed body, without foot and without respiratory appendages. Pleurophyllidiida, numerous gill lamellæ arranged in a longitudinal row in a 
furrow on either side between dorsal shield and foot. Pleuroleurida. Tritoniade. Tritonia. Marionia.

III ClAss: Scaphopoda. Body symmetrical, lengthened in a dorso-ventral direction. Mantle a tubiform sac with a more narrow, dorsal, and a wider ventral opening. Mantle cavity extending at the posterior region as far as the apical aperture. Shell high, shaped like a conical tube, with a smaller apical and a larger ventral opening. Ctenidia wanting. Nephridia paired. Blood-vascular system (independent) reduced to one ventricle without auricles. Sexes separate. Special genital ducts wanting. The right nephridium performs their function. Mouth at the end of a head-like buccal prolongation, and surrounded by a circle of foliaceous appendages. At the base of the head-like prolongation, numerous filamentous appendages arise which are protrusible through the lower opening of the shell and the mantle. Foot stretched, prolonged ventrally. Radula present. Limicolous marine forms. Dentalium. Foot comparatively short, at the end almost acorn-shaped, with a conical middle and two lateral lobes. Siphonodentalium. Foot worm-like, lengthened, at the end widening into a disc, with papillæ along its margin.

IV CLASS: Lamellibranchia (Pelecypoda, Bivalva, Acephala, Aglossa). Body symmetrical, transversely, more or less flattened, with two large, lateral, mantle lobes covering a spacious mantle cavity, within which the hatchet- or club-shaped foot may be withdrawn. Two lateral valves, only connected at the dorsal hinge margin. Either with two transverse adductory muscles (Dimyaria), or with only one (ànterior one reduced, MLnomyaria). On either side of the mantle cavity a ctenidium. Without pharynx, jaw, radula, and tentacles-no separate 
cephalic region. Nephridia paired; genital organs paired, open by separate apertures or by means of nephridia. Heart with two auricles. On either side of the mouth a pair of labial palpi. Hermaphrodites or of separate sexes. Marine and fresh water forms. Limicolous or sessile.

I. Order: Protobranchia. Gill in the posterior part of the mantle cavity, bipectinate, corresponding to the ctenidium of the Zeugobranchia, projecting with its free apex posteriorly into the mantle cavity. Foot adapted for crawling. Pleural ganglion distinct from cerebal ganglion. Family: Nuculida: Nucula. Ledia. Yoldia. Solenomyide.

2. Order: Filibranchia. The gill leaves of the ctenidium lengthened into long filaments, which hang down far into the mantle cavity and consist of two bars, a basal descending and a terminal ascending one. Family: Anomiidce. Mantle open without siphons: Monomyaria. Foot small. Body and shell asymmetrical. Sessile mussels. Gill threads entirely free. Anomia. Placuna. Family: Arcidce. Gill filaments of each series connected by ciliary discs. Dimyaria. No siphons. Large foot. Arca. Pectunculus. Family: Trigonizda. Gills the same as in the Arcidæ. Dimyaria. No siphons. Trigonia. Family: Mytilida (except Aviculidæ). Gill filaments connected by non-vascular sutures. Anterior adductory muscle smaller than the posterior one. (Heteromyaria). Siphons present. Foot stretched. Mytilus. Modiola. Lithodomus (boring mussels). Modiolaria.

3. Order: Pseudolamellibranchia. The successive gill filaments of one series are connected by ciliary discs or by vascular bridges, so likewise each ascending filament with the corresponding descending. Family: Pectenida. 
Monomyaria with entirely open mantle supplied with eyes along its margins. Without siphons. Foot small, tongue-shaped. Shell with equal or unequal valves. Swimming. Pecten. Chlamys. Family: Aviculida. Monomyaria or Heteromyaria without siphons. Valves either equal or unequal. Avicula (Meleagrina). Malleus. Vulsella. Perna. Inoceramus. Pinna. Meleagrina. Margaritifera (pearl mussel). Family: Ostreida. Monomyaria without foot with entirely open mantle without siphons. Valves unequal, fastened by the left valve to a support. Ostrea (oyster).

4. Order: Eulamellibranchia. Gills not consisting of distinct filaments. The filaments of each series and the two bars of a filament are connected by vascular bridges or sutures in such a way that each filamentous series resembles a sieve-like lamella. Thus on either side two such lamellæ exist, which in reality correspond to the two rows of plates of a simple bipectinate ctenidium. Here belong the majority of Lamellibranchia.

I. Suborder: Submytilacea. Gill lamellæ smooth. Mantle usually fused only between the incurrent and excurrent apertures. Dimyaria. Family: Carditidee. Dimyaria with open mantle and large foot. Cardita. Venericardia. Family: Lucinida with simple siphonal openings of the mantle. Foot often vermiform. Family: Erycinidce. Mantle closed except along the two siphonal and the foot openings. Foot long Erycina. Kellya. Lasæa. Lepton. Galeomma. Family: Crassatellida. Mantle open, without siphons. Family: $C y$ renida. Mantle open. Two siphons. Foot large. In fresh or brackish water. Cyrena. Corbicula. Sphærium. Pisidium. Galatea. Family: Dreissensiida, in rivers. Family: Unionida, in fresh water. Foot large, 
hatchet- or club-shaped. Tro simple siphonal openings or slits. Mantle open. Unio. Anadonta. Mutela.

2. Suborder: Tellinacea. Dimyaria with entirely separate siphons. Foot large. Gills smooth. Family: Tellinida: Tellina. Family: Donicida: Donax. Mactride: Mactra.

3. Suborder: Veneracea. Dimyaria. Gill-lamellæ somewhat folded. Siphons separate. Foot rather large. Family: Veneride in Venus. Meretrix (Cytherea). Tapes. Family: Petricolide (boring mussels).

4. Suborder: Cardiacea. Dimyaria or Monomyaria. Gill-lamellæ highly folded. Mantle with two siphonal and one pedal opening, otherwise fused. Family: Cardiidee. Dimyaria. Cardium. Family: Chamide. Dimyaria. Valves unequal. Chama. Diceras. Requienia. Here, probably, belong the fossil Monopleuridæ, Caprinidæ, Hippuritidæ, Radiolitidæ. Family: Tridacnida. Monomyaria. Tridacna. Hippopus.

5. Suborder: Myacea. Dimyaria with folded gill lamellæ. Mantle with tendency towards fusion. Siphons very long. Foot large. Family: Psammobiida. Pectal aperture of the mantle still very large. (Psanımobia.) Family: Mesodesmatida. Lutrariida. Myïda. Mya. Corbula. Glycymerida. Glycymeris. Saxicava (boring mussels). Solenida. Shell gaping at both ends. Foot very large. Solenocurtus. Cultellus. Ensis. Solen.

6. Suborder: Pholodacea. Dimyaria with fused mantle and well-developed siphons. Foot variable, sometimes rudimentary. Shell gaping, frequently with accessory pieces. Family: Pholadida. Boring mussels. Pholas. Pholadidea. Jouannetia. Xilophaga. Family: Teredinida, boring mussels. Teredo (so-called Ship-worm). 
Family: Clavagellide. Clavagella. Brechites (Aspergillum).

3. Suborder: Anatinacea. Mantle extensively fused. With siphons. Hermaphrodites. Foot present. Family: Pandorida. Lyonsiida. Anatinida. Anatina. Thracia.

5. Order: Septibranchia. The gill is transformed on either side into a muscular, perforated septum, which divides the mantle cavity into two chambers, one above the other. Hermaphrodites. Families: Poromyida. Cuspidaridce.

V CLAss : Cephalapoda. Body symmetrical, with high visceral sac. Around the mouth tentacles or clasping arms, considered to be parts of the foot which have grown anteriorly around the mouth. Another part of the foot is the funnel. In the posterior mantle cavity two or four ctenidia. Heart with two or four auricles; two or four nephridia. Unpaired gonads with paired or unpaired duct. Sensory organs, especially the eyes at the sides of the cephalic foot, highly developed. Strong jaws and firm radula. With external or internal shell, or without shell. Usually with ink-bag. Large, predatory marine animals of separate sexes.

I. Order: Tetrabranchiata. With external chambered shell, in whose last (largest) chamber the animal dwells. Shell symmetrical, exogastrically coiled up. Numerous tentacles without suckers and retractable into special sheaths arise upon larger lobes around the moutb. Four gills, four auricles, four nephridial organs. Funnel consists of two lateral, separate lobes, which, with their free edges reaching one above the other, form a tube. Without ink-sac. With concave eyes. Only living form Nautilus. Radula 2. 2. I. 2. 2. The two large groups of the Nautiloidea and Ammonitidea extinct. 
2. Order: Dibranchiata. Shell internal or rudimentary, or wanting. . Rarely (entogastrically) coiled. Two gills. Two auricles; two nephridia. Eight or ten clasping arms with suckers around the mouth. The two lobes of the funnel fused along the free margin. Vesicular eyes. With ink-sac.

I. Suborder: Decapoda. With internal, often rudimentary shell. With ten arms, the fourth pair of which is developed into long prehensile tentacles, retractable into special cephalic cavities. Good swimmers with dorso-ventrally elongated body provided with lateral fins. Genital ducts unpaired. Family: Spirulida. With internal, spirally twisted, entogastrically coiled shell. Spirula. Family: Belemnitida. Fossile forms with internal chambered, generally straight shell. Belemnites. Spirulirostra. Belemnotenthis. Family: Oigopsida: Ommastrephes, rad. 3. I. 3. Loligopsis. Cranchia. Chirothenthis. Owenia. Thysanotenthis. Onychotenthis. Ommatostrephes. Family: Myopsida: Rossia. Sepiola. Sepiodarium. Idiosepion. Loligo. Sepiotenthis. Belosepia (fossi1). Sepia, rad. 5. I. 3 .

2. Suborder: Octopoda. Without shell; with eight arms; without prehensile tentacles. Body plump, usually without fins, little adapted to swimming. Genital ducts paired. Family: Cirrhotenthida. With fins. Family: Philonexida. Argonatua, female with external unchambered shell. Philonexis. Tremoctopus. Family: Octopedide. Octopus, rad. I. 3. I. Eledone.

Appendix: Rhodope Veranii. A small animal, 4 mm. long, spindle-shaped, externally bilaterally symmetrical. Body epithelium ciliated; with cutaneous muscular envelope, in which calcareous particles are embedded. Alimentary canal without radula, jaws and 
liver. Nervous system with two supra- and one infraœsophageal ganglion, with transverse commissures and connections, with eyes and auditory vesicles. Longitudinal cords. Hermaphrodite with complicated genital apparatus. No separate blood system. One spacious, ciliated, nephridial chamber. Development direct; no shell formation. Its systematic position still disputed.

Organization of the Mollusca. The body of a primitive Molluscan type is bilaterally symmetrical with a convex dorsal region; the anterior region, containing mouth, eyes and tentacles, constitutes a distinct part of the body, the head. The ventral region is distinguished by a separate strong muscular plate, the foot, adapted for crawling. The soft integument of the convex dorsal region produces on all sides a large, overhanging fold, the mantle (pallium), which covers a circular cavity, the mantle cavity surrounding the trunk and communicating through the free margin of the mantle with the medium in which the animal lives. The dorsal integument of the trunk and its continuation, the external integument of the mantle secretes a closely joinirg shell consisting of a chitinous matrix (conchyliolin), in which carbonate of lime is deposited. This shell is like the dorsal region, bilaterally symmetrical, convex. Separated from the body it would resemble a cup or plate. It serves both as a protection to the dorsal region and as a skeleton to which the muscles of foot and head are attached (dorsoventrally directed). The mantle does not only form and enlarge the shell by its marginal secretions, but also covers the delicate gills and procures for them the protection of the shell. We have a similar mechanism in the carapace of higher Crustacea and the branchial operculum of the fish. In the Mollusça the relations between 
gills, mantle, and shell are of the utmost importance. The gills, situated in the mantle cavity, are paired and symmetrical, there may have been originally a series of successive gills or only two on either side of the posterior region of the mantle cavity. Each gill is shaped like a feather, consisting of a central axis or shaft and a double row of numerous (barb-like) side branches. The shaft rises free from the trunk into the mantle cavity. Near the base of each gill there lies a sensory organ (of smell), called the osphradium. Such a gill has a definite morpholigical value. It has been termed a ctenidium, in order to distinguish it from analogous respiratory organs, occurring in certain Molluscs. The head bears a pair of tentacles and a pair of eyes. The mouth is situated at its anterior ventral side; the apertures of the internal organs at the posterior end of the trunk above the foot. Here, also, is found in the median line the anus, and on either side between it and each ctenidium (if we accept only one pair) two openings occur, one for the sexual organs and one for the nephridium. All these apertures (two ctenidia, two osphridia, anus, paired sexual and nephridial openings) are covered by the mantle and, therefore, lie in the mantle cavity. These parts constitute together the complex of pallial organs.

The deviations from the primitive external organization as given abcve, have largely been indicated under the different classes and orders. In the Placophora the contours of the foot with a cephalic region in front of it, run parallel to those of the body. The mantle is represented by the peripheral region between the margin of the body and the calcareous plates. It presents numerous scattered spines, which are sometimes hard and chitinous and sometimes calcified, arising in 
special follicles lined by ectoderm cells. Between the mantle and the foot a furrow (mantle cavity) occurs containing on either side a series of leaf-like gills, which may either form an almost complete circle of gills around the foot or be confined to the posterior region. Eyes and tentacles are wanting. The body of the Gasteropoda exhibits a multitude of modifications; it is either bilaterally. symmetrical or highly asymmetrical. The same is true of the whole external structure. Usually the dorsal region of the body containing the viscera assumes a constricted sac-like form which, for the sake of reducing surface extension, coils itself spirally and forms a corresponding shell into which the protrusible head and foot can be withdrawn. The integument of the viscera sac may form along any place of the body an overhanging mantle fold, protecting the gills and aiding in the formation of the shell. In the Prosobranchia the pallial complex is not situated at the posterior, but at the anterior region of the body. The originally paired organs become (usually) unpaired and thus the asymmetry very prominent. They are called Prosobranchia because the gills are situated before the heart, whilst in the Opistobranchia the reverse is the case ; the pallial margin of the latter never forms a distinct siphon. The mantle cavity of the Pulmonata is filled with air (gills wanting), respiration being carried on by the vascular network, covering the internal surface of the mantle fold immediately in front of the heart. At the base of the head-prolongation of the Scaphopoda two tassel-shaped masses of long filiform contractile tentacles arise which hang down into the mantle cavity, and can be protruded through the ventral mantle opening. The anus occupies a median posterior position 
above the foot with a nephridial opening on either side. The mantle fold of the Lamellibranchia is attached to the trunk along its whole base; it encloses a cavity whose transverse diameter is very much shorter than the dorsoventral or longitudinal, i. e., the whole body is coinpressed. The two valves of the shell articulate at the dorsal region and gape along the ventral margin. The two adductor muscles (anterior and posterior) which transversely connect the two valves, produce distinct impressions on their inner surface. The mouth is situated between the anterior adductor and the anterior base of the foot; the anus (frequently fringed) behind the posterior adductor. A distinct cephalic region is wanting. Along the line of the pedal insertion, on either side of the median and posterior part of the trunk a longitudinal septum (shaft) arises to which are attached numerous long gill-leaves, arranged in two rows, i. e., one gill lies on either side of the mantle cavity. It is of great importance to observe in the different groups of Lamellibranchiata that the mantle can partially close itself whenever the free margin of the right fold fuses with the free margin of the left fold at one or more than one place. This leads to the formation of siphons which are contractile and extensible, governed by muscles. The body of the Cephalopoda is morphologically so arranged that the apex of the large visceral sac accupies the highest point of the dorsal region (apparently the posterior end), whilst the head (transformed into a cephalic foot) with its prehensile anus occupies the corresponding ventral position (apparently anterior end.) The morphologically anterior side is apparently above, the posterior below. (Compare the position of a Sepia in water.) The mantle fold, hanging down posteriorly from 
the visceral sac covers a spacious mantle or branchial cavity which communicates above the cephalic foot through the mantle aperture with the external world. On the floor of the mantle cavity two or four symmetrically arranged gills are situated. In the posterior lower side of the visceral sac two symmetrically shaped lobes arise, approaching each other in such a way as to form a tube, the so-called funnel, whose one opening lies in the mantle cavity while the other appears outside of it, beneath the pallial aperture. The water of respiration flows from the mantle cavity into the funnel and thence to the outside. The funnel is also used as an eductory passage by the frcal masses, the excretions, the genital products and the secretions of the ink-sac. Originally all Cephalopoda very probably possessed a complete shell covering the visceral sac and the mantle fold. Its modern form is either rudimentary or wanting altogether. The vacant chambers of the shell of the Tetrabranchiata are filled with gas; partitions separating them are perforated in the center by a siphon which traverses all chambers and is fastened to the visceral sac of the animal (Nautilus). That part of the foot which surrounds the mouth is drawn out into numerous tentacles, each one of which can be retracted into a special sheath; the anterior end situated before and above the head is widened into a concave lobe, the so-called cephalic cap, which lies external to the anterior part of the dwelling chamber, closing the shell when the tentacles are withdrawn. The cephalic cap bears two tentacles. On either side of the head one eye is located. The mantle fold extends above the cephalic foot around the whole body. Whilst it is short along the sides, it forms a considerable lobe in front and above, and covers posteriorly a very 
deep cavity. The funnel consists of two entirely separate lateral lobes (epipodial lobes) representing a part of the foot. Within the mantle cavity (upon the visceral sac) two pairs of pectinate gills (upper and lower) arise. Here also nine apertures occur: the median anal, two genital, two nephridial and two viscero-pericardial. The mantle fold of the Dibranchiata extends as a narrow margin along the lateral regions and the anterior side of the visceral sac, forming immediately above the cephalic foot a furrow, whilst it covers almost the entire posterior surface of the visceral sac, producing a very deep and spacious mantle cavity. The two lateral lobes of the funnel are fused along their free margins into a tube open on both ends; near the upper end the openings of the internal organs appear. The two gills are situated, one on the right and one on the left side in the mantle cavity.

The whole Molluscan body is covered by a one-layered epithelium, which is usually ciliated in all parts, not covered by the shell. It is very rich in glands of the unicellular type, situated either in the epithelium itself or in the subjacent tissue with their ducts between the epithelial cells. The tissue immediately beneath the epithelium (connective tissue, muscular fibres) is distinguished as the leathery integument or cutis, but there is no sharp line of separation between this and the tissues beneath it. In the cutis of the Ceplialopoda large chromatophores occur which through alternating contractions and expansions produce the beautiful change of color. Likervise the free pallial margin of the Gasteropoda from which the formation of the shell proceeds, contains numerous mucous chromatous and calcareous glands. The shell of the Lamellibranchiata consists of 
three lamina: the external layer (horny cuticula), the intermediate (porcellan layer), consisting of perpendicular calcareous prisms, and the internal layer or mother of pearl, composed of five calcareous plates, arranged in delicate wave-like folds, which produce the wavy lines of the internal surface. The two first layers are developed from the free pallial margin, the last one from the epithelium of the mantle. The shell of the Gasteropoda and Cephalopoda consists largely of the porcellan layer, structurally different from that of the Lamellabranchiata. Comparing the growth of the shell with that of the exoskeleton of the Arthropoda we find that the former leaves the animal free and enlarges with it through the addition of new layers, or through anterior enlargement, into which the growing animal moves, leaving the posterior smaller chambers vacant (Nautilus), whilst the latter must be repeatedly shed in order to allow the animal to grow. An originally asymmetric shell may in the course of time become symmetric or vice versa. The shell serves functions of protection, and therefore becomes complicated and variously coiled in freely moving animals which show the tendency to retract the whole body within their own shell. It has been definitely proved that forms with rudimentary or no shell at all must be derived from forms with a well developed shell. In all defective cases a shell generally becomes first internal, then decreases in size, the visceral sac becomes reduced, the shell occurs only in form of isolated calcareous corpuscles in the dorsal integument, finally even these disappear and the shell is only present in the embryo. The environments frequently require the reduction of the shell, but other compensations arise to take its place. The valves of the Lamellibranchia are 
connected by the hinge and the hinge ligament, consisting of an external non-elastic and an internal elastic layer. Many modifications occur. The pallial line, formed along the margins of the valves by the muscle fibres fastening the pallial margins forms in molluscs, provided with siphons, a characteristic modification, the mantle sinus, corresponding to the impressions of the siphoretractor muscles and important for classification.

The most important organ of the mantle cavity is the branchial organ or gill, because mantle and mantle cavity were formed for its protection. It is a homologous organ derived from the gill of a common ancestral type, and therefore a definite morphological factor, designated by the name ctenidium in contradistinction from the secondary gills, which are morphologically different. The ctenidia of the Mollusca are originally paired, symmetrically arranged, pectinate, ciliary processes of the body wall, projecting from the trunk into the mantle cavity. Afferent vessels (branchial arteries) conduct venous blood into the gills, whence afferent vessels conduct the newly oxidized (arterial) blood back into the body, first into the heart. At the base of each ctenidium lies the osphradium (Spengel's organ). The gills have retained their most typical character in the Chitonidæ, the Lamellibranchiata, Cephalopoda and Zeugobranchia, only that in the latter the gills changed their original position. The asymmetry of the body manifests itself also in the gills, wherever only one is retained. The ctenidia of the Testibranchiata (exceptions) have disappeared together with the mantle cavity, but may be replaced by analogous adaptive gills. Since blood is carried from the gills into the auricles of the heart, there is an important relation between the two organs, i. e., the number and position 
of the gills corresponds to those of the auricles (except in the Chitonidæ). In the Scaphopoda respiration is carried on by the soft portions of the integument. The chief forms of the adaptive gills of the Nudibranchia are (I) the anal gills of the Dorididæ, (2) the right and left longitudinal rows of the subpallial gill plates of the so-called Phyllidiidæ, (3) the dorsal appendages or cerata of the Nudibranchiata and of most Ascoglossa. In the Pulmonata the mantle cavity becomes a lung cavity. On the internal delicate surface of the mantle a dense respiratory blood-vascular network arises. A vein, the circular vein, runs along the mantle thickening, sending out numerous fine, anastomosing vessels, which enter into the large lung vein (arterial blood), parallel with the rectum, and thence into the auricle. Similar cases occur in the terrestrial Prosobranchia.

The hypobranchial gland is situated at the base of the ctenidium or betwen it and the rectum. It assumes various forms, but never becomes follicular or tubular. The purple gland of the Prosobranchia is such a gland.

The absence of the head in the Lamellibranchiata is due to the peculiar development of the mantle and shell which separate the anterior region from the external world, and make the existence of a special highly sensitive cephalic region superfluous. Specially noteworthy are the cephalic foot of the Cephalopoda, the head of the Gasteropoda and the oval anterior head-like prolongation of the Scaphopoda.

The mouth opening of the Lamelliabranchia continues to the right and the left in a furrow which extends posteriorly to the base of the gills. Its function is to conduct food particles to the mouth. It is bordered by septa which form a kind of upper and lower lips; they may hang 
into the mantle cavity in form of thin triangular plates, called oral lobes or palpi.

The strong muscular foot is evidently the remnant of the ventral portion of an original cutaneous muscular envelope, adapted to crawling, whilst the formation of a shell made the dorsal portion superfluous and caused its reduction. The foot with a flat sole is no doubt the original type. It may be greatly modified by adaptation. An anterior portion (propodium) may become distinct from a posterior position (metapodium) which bears the operculum wherever it occurs; or parapodia may arise by lobe-like enlargements of the margin of the sole; or an epipodium, a projecting fold, may develop around the base, i. e., the upper part of the foot; it is here where tentacular processes occur. In the Heteropoda the (medio-ventral) propodium has adapted itself to the function of swimming and transformed into a vertical fin, the parapodia of the Tectibranchia have changed into paired fins or wings. In the Cephalopoda the foot has gradually moved towards the head, finally fusing with it, so that the arms (brachial umbrella) are considered lateral processes of the foot, especially on the ground that the sub œsophageal branchial ganglion which innervates the brachia, represents an anterior differentiation of the pedal ganglion, further because the brachia arise ontogenetically behind the mouth on the ventral side; their later position is only a secondary one. It can hardly be doubted that the two lobes of the funnel are epipodial lobes. The chief pedal glands of the Gasteropoda consist of an anterior glands (salivary) situated in the Prosobranchia between the two pedal lips (lobial gland), in the Pulmonata in the median basal line forming an epithelial canal; and of the unpaired sole gland, 
occurring largely in the Prosobranchia, where they secrete a saliva that can be drawn out into threads, by means of which the animals attach themselves to foreign objects; it is homologous with the byssus gland of the Lamellibranchia. The foot, the latter is generally laterally compressed, originally ending in a disc with marginal indentations. The byssus apparatus consists of (I) the byssus cavity, (2) the eductory canal, (3) the byssus furrow, extending from the opening of the canal to the anterior point of the foot, and (4) of a cup-shaped or semilunar enlargement of the furrow. The animal fastens itself by means of the byssus threads to foreign objects.

The primitive internal organization of the Mollusca is as follows: The alimentary canal. The mouth leads into a muscular pharynx with horny jaws; on its floor lies a hard plate called tongue or radula, which in successive transverse rows bears sharp, chitinous teeth. Paired salivary glands open into the pharynx. This is followed by an cesophagus leading into a midgut, which assumes a colled shape and traverses, surrounded by large digestive glands, the body, ending posteriorly by means of a very short hindgut in a median anus. Wherever the body has developed a dorsal visceral sac (Gasteropoda) the alimentary canal forms a dorsal loop. Secondary loops or coils of the midgut are especially prominent in herbiverous Mollusca. The digestive gland, or so-called liver, unites the functions of the different specialized digestive glands of the Vertebrata. The radula is not present in the Lamellibranchia; they are, therefore, called Aglossa in contradistinction from all other Mollusca the Glossophora; the hard jaw and salivary glands of the latter are likewise wanting in the former. The reason of this distinction in the Lamellibranchia is to be sought in the fact 
that they feed after the manner of sessile animals; microscopic organisms are carried from the incurrent water by ciliary motion into the mouth; there is no need of special masticatory organs. The anal gland of some Gasteropoda and the so-called ink sac of the Cephalopoda are connected with the terminal part of the hindgut. The wall of the alimentary canal is attached by connective fibres or bands, and consists of an internal, usually ciliary, epithelium, an external muscular layer and an external connective envelope. Pharynx and perhaps also parts of the œsophagus arise ontogenetically from the octodermal stomodæum or proctodæum. The tongue is a tough, muscular, longitudinal structure, covered with a strong cuticular basal membrane, upon which numerous, often thousands of chitinous little teeth arise, arranged in transverse and longitudinal rows. Basal membrane and teetl together constitute the radula, which is of the highest systematic value. It has its origin at the base of a sheath, into which it penetrates. Pharynx and tongue apparatus are protrusible, forming a very long proboscis in some predatory Prosobranchia. The œsophagus is situated between pharynx (wanting in Lamellibranchia) and stomach; there is hardly a line of demarkation. The stomach is that part of the midgut into which the liver opens. The liver is either a tubulous or acinous gland, representing a compact multilobed organ of brownish color. It consists of hepatic, ferment and calcareous cells. One of the diverticula of many Lamellibranchia contains a rod-shaped, gelatinous cuticular mass, the crystalline style, whose nature is still disputed. Numerous modifications of the midgut occur, especially in the Cephalopoda (pancreas, spiral column). 'In the Aphistobranchia chitinous formations occur in the stomach. The tubular intestine of the 
midgut exhibits numerous coils and loops. In the large majority of the Lamellibranchia and Diotocardia the rectum perforates the heart, which suggests a relationship of groups.

The primitive muscular structure consists of the muscles of the foot, of the muscles extending from the shell to the foot and the head (muscle of the spine, shell muscle), and of the muscles of the individual organs. The structure of the muscles is not cross-striped. The spindle muscle (musculus columellaris) is attached to the spine in the interior of the shell, extends along the visceral sac and enters the dorsal side of the foot, where it radiates. It constitutes the specific retractory muscle, and is as such most highly developed in the Pulmonata where it forms the retractory muscles of the tentacles, eye-stalks and buccal mass and the muscles extending to the viscera. In the Lamellibranchia we distinguish the pallial muscles and the muscles terminating in the foot. The former is especially developed towards the free edge of the mantle and consists of three systems (I) the perpendicular muscular fibres of the pallial margins, (2) the muscle fibres running parallel to the pallial margin, (3) short fibres extending from the internal to the external pallial surface. Differentiations of the pallial muscles are the siphonal retractors and the adductor muscles. Mollusca with two equal adductory muscles are called Dimyaria, those in which these muscles are unequal, Heteromyaria, and those with only one adductor, Monomyaria. The muscle pairs extending from the internal surface of the shell into the foot correspond to the columellar muscles of the other Mollusca. In the Cephalopoda a cartilaginous entoskeleton is developed which serves, on the one hand, purposes of attachment for various muscles, muscle 
groups and membranes, on the other hand purposes of protection for important organs, especially for the central parts of the nervous system and the eyes. Constant is only the cephalic cartilage. Muscles are attached to the cartilage of the shell (depressor infundibuli; retractor capitis lateralis; capitis medianus), or of the fin, or of the head (musculus collaris: adductor infundibuli).

The primitive nervous system consists of two welldeveloped cerebral ganglia, situated on the dorsal side of the head and connected by a short cerebral commissure, and of two pairs of strong ganglionic nerve trunks, pro. ceeding each from a central ganglion and traversing the whole length of the body. The two trunks of the one pair, the pedal cords, extend along the right and left side of the foot, the visceral cords occupy a deeper and more dorsal position, extending along the body cavity and connected posteriorly. Excepting the Amphineura and the Diotocardia, the nervous system is modified as follows: tro cerebral ganglia, two pedal ganglia, two pleural ganglia (on both sides of pharynx), two visceral ganglia (in the posterior region of the body cavity). Naming the ganglia of one and the same side connectives and the nerves, connecting the paired ganglia of both sides, commissures, we distinguish (I) cerebral commissures (above the foregut), (2) pedal commissures (below foregut), (3) visceral commissures (below rectum); further (I) cerebro-pedal connectives, (I) cerebro-pleural connectives, (3) pleuro-pedal connectives, (4) pleurovisceral connectives. The nervous system of the Amphineura corresponds in the main to the original primitive nervous system of the Mollusca. The pedal and visceral cords are connected anteriorly by a ganglionic cerebral semi-circular cond, and exhibit through$\mathrm{L}^{*}$ 
out the body a great resemblence to the rope-ladder nervous system of the Turbellaria and Trematoda. In the Solenogastres the tendency arises to form localized ganglion centres, with a fused cerebral ganglion, three pairs of posterior visceral ganglia and two anterior pedal ganglia. The typical nervous system of the Gasteropoda is the modified primitive system given above, but it becomes highly interesting through the formation of cruciform pleuro-visceral connectives, occurring in the Prosobranchia. The connectives cross each other in such a way that the one starting from the right pleural ganglion extends above the alimentary canal to the left side before reaching the visceral ganglion, whilst the connective proceding from the left pleural ganglion extends beneath the alimentary canal towards the right side. Thus the parietal ganglion (in the pleuro-visceral connective) of the right pleural connective becomes a supraintestinal ganglion (on the left side): the one from the opposite direction becomes a subintestinal ganglion (on the right side). The Prosobranchia are therefore streptoneurous Gasterapoda, whilst the Opisthobranchiata and Pulmonata are euthyneurous Gasteropoda. The cerebral ganglia innervate the eyes, auditory organs, tentacles, proboscis, lips, retractory muscles of proboscis and buccal mass; the pedal ganglia furnish nerves for the pedal muscles (rarely for the spindle muscles); the pleural ganglia innervate mantle, spindle muscle and post-cephalic body wall; the parietal ganglia, the ctenidia, osphradium and partly the mantle; the visceral ganglia, the visceral sac. The connectives and commissure may also furnish nerves for the neighboring ganglia. The buccal ganglia innervate the pharynx, salivary glands, œsophagus, anterior aorta, etc. The nervous system of the 
Seaphopoda is symmetrical, the visceral connective not cruciform, no separate parietal ganglia; the main ganglia lie closely together. The nervous system of the Lamellobranchiata consists of the cerebro-pleural ganglia (fused) with commissures, the pedal ganglia and the visceroparietal ganglia with commissures, all three connected by long connestives. The symmetric nervous system of all Cephalopoda is characterized by the marked concentration of all the ganglia, especially in the Dibranchiata, where the central nervous system is enclosed by the cephalic cartilage. The buccal ganglia represent the sympathetic nervous system.

The integument of the Mollusca contains a large number of variously arranged epithelial sensory cells. They are of two kinds, either large surface cells (only in Lamellibranchiata), carrying tufts of externally projecting sensory hairs (brush-cells), or elongated filiform or spindle cells, which show a slight elevation near the nucleus. Both kinds of cells continue at their base in a nerve fibre, leading to the nervous system. They have no specialized functions, unless they combine into special sensory organs. Between these sensory cells other epithelial cells occur, e. g., glandular, ciliary, supporting cells, etc. The function of touch manifests itself wherever the integument is exposed. Sensory cells occur also on the internal epithelium of the mantle; they may be of an indifferent, or of a glandular or of a sensory nature. A whole region may assume their character wherever the one or the other kind predominates. The osphradium of the Prosobranchia is such an organ, performing the function of smell. Tentacles of smell occur in terrestrial Pulmonata and certain Opisthobranchia, whilst in the Dibranchiata distinct innervated pits may 
take their place; similar organs occur on both sides of the anus in certain Asiphoniata. Here belong likewise the lateral organs of Diotocardia, the sensory organs of the Chitons (subradial, megalæstheta and mikræstheta), and the oral organs of taste in many Mollusca. All Mollusca, except the Amphineura have auditory vesicles (otocysts), whose epithelial wall consists of ciliated and sensory cells; the vesicle contains otoliths of various numbers (I-IOO), size and composition They are generally situated upon the pedal ganglia or near them. They reach their highest development in the Heteropoda and the Ceplialopoda, where maculæ and Cristæ acusticæ are formed. Eyes occur in the form of cup-shaped (in Diotocardia and Nautilus), and vesicular eyes, (see p. 56-58). The eyes of the Dibranchiata belong to the highest in the animal kingdom (p. 56). The dorsal eyes of Onchidium and of Pecten and Spondylus belong to the vesicular eyes, but here the external wall develops into the retina whilst the internal wall represents pigmented epithelium. The compound or facetted eyes of Arca and Pectunculus are epithelial organs corresponding to certain simple Arthropodal eyes. Originally the eyes of the Mollusca were evidently homologous, but adaptation brought about a change.

The primitive original blood-vascular system is partly lacunary. The heart is arterial and situated in the pericardium above the rectum. It consists of a ventricle and two lateral auricles. In symmetric Mollusca with high visceral $\mathrm{sac}$, it is displaced behind the rectum. In the asymmetric Gasteropoda the position of the heart depends upon that of the pallial complex. Usually two large arteries (aorta) arise (frequently with one stem) from the heart, the one proceeding to the head, the 
other to the visceral sac whence they anastomose and empty into the lacunæ. The blood circulation has been described before. The blood or, better, the hamolymph, is rich in albumen (hæmocyanin), and contains free swimming amœbid cells, which either separate from localized blood glands or from larger vascular regions. The wall of the heart consists of densely packed, smooth muscle fibres and of an external entothelium (pericardial). An internal entothelium is wanting. The wall of the ventricle is always stronger than that of the auricles. Valves occur between the two (atrioventricular) as well as in the peripheral canals. The heart may also be innervated. The somewhat complicated blood-vascular system of the Cephalopoda deserves special attention.

We distinguish in the Mollusca a primary and a secondary cavity. The former represents the lacunar and sinus system of the body, into which the arteries open and from which the veins, whenever they are present, receive their blood. It is without its own epithelial wall. The so-called secondary body cavity or the colum is in the large majority of Mollusca greatly reduced and consists usually only of the pericardium and the cavity of the gonads (testes, ovaria, hermaphroditic glands). It is always lined by its own epithelial wall, the entothelium of the blood cavity. It communicates externally through the nephridia (same as in Annulata). The germ layers are accumulations of the entothelium, so also the pericardial glands.

The nephridia (organ of Bojanus) consist typically of two symmetrical sacs which open externally through the two nephridial apertures into the mantle cavity, and through two internal apertures (infundibulum) into the pericardium. Their wall is richly saturated with 
venous blood which here deposits its excretory substances. Modifications and relations to the genital glands have been indicated before.

The sexual organs consist of the gonads, the ducts and the organs of copulation. The gonads are either completely or incompletely separated parts of the secondary body cavity; they are paired and symmetrical in the Lamellibranchia and Solenogastres. In all others they are single. Two pairs of gonads may be present in Hermaphrodites, but ova and spermatoza are here usually produced by one and the same gonad. (See classification.) They may be situated above the alimentary canal (Solenogastors) or in the visceral sac (Gastropoda, Scaphopoda, Cephalopoda) or typically in the primary body cavity above the muscular part of the foot between the alimentary coils. The reproductive cells may arise everywhere from the epithelium of the gonads or only in certain definite regions; they mature, separate and enter the secondary body cavity whence they are carried out. The gonads empty the mature eggs either into special ducts or into the nephridia. In many molluscs they pass through the pericardium (Solenogastres) before reaching the nephridia. Whenever the gonads open directly into the latter, they either enter its proximal (communicating with the pericardium) or its distal portion (urinary duct) or a urogenital cloaca. The relation between paired ducts and paired or unpaired gonads is indicated in the classification. Whenever special ducts are present accessory pouches or glands or organs of copulations arise which are most complicated in hermaphroditic Pulmonata and Opisthobranchia. In the Gasteropoda a male organ (either a freely projecting penis or a similar protrusible organ) arises in the cervical region. 
In the Cephalopoda a modified (hectocotylized) arm of the male assumes the function of copulation. The spermatazoon is usually pin-or hair-shaped. In parasitic and sessile snails the organization becomes rudimentary. Certain Gasteropoda are viviparous.

Ontogenetic and phylogenetic characteristics. The Molluscan egg generally undergoes a total unequal segmentation (discoidal in Cephalopoda), resulting either in an invagination or an epibolic gastrula (p. p. 38-40). The characteristic larva is the veliger-larva, i. e., a trochophora with Molluscan characteristics: (I) the dorsal. shell-gland with the embryonic shell (or shells), and (2) the ventral foot-rudiments. Metamerism occurs before all the trochophora characters have become fully developed. The preoral ciliary circle (the velum) of the Molluscan larva corresponds to the same structure in the Turbellarian larva; the primitive nephridium of the former to a simplified water-vascular system of the latter, whilst the constant nephridia as genital ducts are homologous with the genital ducts of the Turbellaria. With the acquirement of rectum, heart and secondary body cavity the Mollusca rose above the modern Platoda, whilst they are still one (in the lower forms) with them with regard to the nervous system. The secretion of a shell changed the respiratory functions of the body surface and led to a formation of localized gills; at the same time the muscular structure of the dorsal side, and with it the longitudinal nerve cords, became reduced, whilst the opposite took place with the ventral muscular structure; which developed into a foot; the dorso-ventral muscles, however, into a shellmuscle. 


\section{ECHINODERMATA.}

The Echinoderms are exclusively marine animals. They exhibit externally a radial usually pentamerous arrangement. This radial symmetry is never perfect, the body is in reality bilatterally symmetrical in rela- tion to a median plane which traverses the centre of length of one of the radiating metameres. They are always provided with a skeleton, composed of calcareous spicula, which usually unite into networks, giving rise to definite skeletal plates. An alimentary canal is present whose walls are separated from the body walls by a spacious peritoneal cavity. A systein of ambulacral vessels, composed of a circular canal around the mouth, which sends off a branch canal with numerous lateral prolongations along the middle line of each of the ambulacral metameres, represents the highly characteristic watervascular system. Hatschek, therefore, names this group Ambulacralia, classifying them together with Enteropneusta as a special type. A true vascular system is also present. The nervous system consists of a wing which surrounds the œsophagus and gives off radiating longitudinal cords. Reproduction is mainly sexual, and separate sexes are the rule. The development presents a complicated metamorphosis, the embryo leaving the egg as a bilaterally symmetrical larva, which has different names in different classes.

I CLASS: Crinoidea (Feather-Stars). Bursiform or cup-shaped Echinodermata. Inferior or dorsal integu- 
ment of the body (calyx) always provided with polygonal plates, articulated by their edges; in the ventral integument sometimes only scattered calcifications. At the border of the calyx from two to eighteen segmented arms (brachia) arise, beuring ambulacral appendages (pinnules), which are continuations of those situated along the ambulacral furrows of the calyx. Attached by the apical pole either directly or, more commonly, by means of a calcareous stem to submarine objects. Segments of the stalk usually pentagonal, connected by bands of tissue. It is attached at its distal end by a rootlike expansion or by numerous branched cirri; at certain intervals it bears hollow and segmented cirri, which are arranged in whorls. Through the centre of the stem runs a canal containing a soft, solid substance, and performing nutritive functions. Mouth and anus situated on the ventral side of calyx. Generative rhachis in the arms. Largely extinct (Paleozoic). Represented by only a few living genera.

I. Order: Tesselata. Calyx formed of calcareous plates, oval face without ambulacral furrows. Cyathocrinus. Actinocrinus. Extinct.

2. Order: Articulata. Oval face of calyx, usually membranous, or sub membranous, with ambulacral furrows. I. Family: Pentacrinida. A1ways attached by a pentagonal stalk, with whorled cirri Pentacrinus caput Medusa and P. Mülleri, Rhizocrinus Holopus. Fossi1 forms: Encrinus liliiformis. Apiocrinus, etc. 2. Family: Comatulida. Attached only in the young state. Usually ten arms at the margin of the flattened body by means of which they propel themselves; mouth and anus pres- . ent. The vermiform larva swims about freely, and passes later into the stage of the stalked Pentacrinus, from 
which the Comatula is produced by the separation of the cup from the stalk (Claus). Antedon (Pentacrinus Europæus). Actinometra.

I Appendix: Cystidea. With short stalks and slightly developed arms. Generative organs enclosed in the calyx, issuing through movable valves, arranged around a central pore. Spharonites. Caryocrinus. Apicystites. Extinct.

2. Appendix: Ederioasterida. Fossil. Ambulacra perforated by canals, opening directly into the calyx-cavity. Without anus and stalk. Edrioaster. Agelacrinites. Hemicystides.

3. Appendix: Blastoidea. Prismatic body. Without arms; calyx with ambulacral areas, attached by a short jointed stem. Pentatrematites. Extinct.

II Class: Echinoidea. Body spheroidal, oval, discoid or heart-shaped, with immovable skeleton (shell, test or perisome), composed of calcareous pentagonal plates, bearing movable spines and usually arranged in twenty meridional rows, which correspond in alternate pairs with the radii and interradii (corona). The radial pairs, representing the ambulacral plates, emit the ambulacral tube feet through fine pores arranged in rows. Both ambulacral and interambulacral plates bear spherical prominences and tubercles to which the differently shaped movable spines are joined. Between the latter pedicellariæ occur, which are especially numerous in the region of the mouth. The genital pores are situated on the interradial genital plates near the apical pole. Beneath them lie the reproductive organs, large racemose glands. One of these plates is perforated by numerous fine holes, serving as a communication between the stone canal and the outside (madreporic plate). The arrange- 
ment of the nerves and the ambulacral vascular trunks is highly characteristic of the internal organization. There is invariably a mouth surrounded by oval plates. the peristome, (frequently provided with teeth) and anus protected by anal plates; the periproct and the ambulacral appendages have often respiratory finctions. Echinoids live near rocky coasts. Many are fossil.

I. Section: Regularia or Entocyclica. Mouth central or sub-central; anus sub central in the apical space.

r. Order: Cidaridea. Sea-urchins. With teeth and masticatory apparatus, with equal band-shaped ambulacra. Madreporic plate in the anterior right interradius near the apex.

A. Shell round. Families: Cidaride, with smooth, perforated tubercles; ten anal plates; no buccal branchiæ. Cidaris. Diatematida, with crenulate perforated tubercles, peristome notched. Arbaciada, with smooth imperforate tubercles; four large anal plates; auriculæ closed. Arbacia. Echinida, imperforate tubercles or perforate and crenulate; numerous anal plates; pairs of pores in rows of three, four or more. Strongylocentrotus. Echinus. Hemiaster.

B. Shell oval or elliptical. Echinometrida. Pores in rows of five or six pairs. Echinometra. Podophora. Acrocladia. In the family Salenidx the anus has become eccentric through one or more supernumerary apical plates. The only living form: Salenia rarispina. Echinothurida extinct.

2. Section: Irregularia or Exocylica. Anus eccentric, not within the apical disc.

2. Order: Clypeastridea. Irregular Echinoidea, more or less shield-shaped. Mouth usually central, provided with masticatory apparatus; five-leaved ambulacral rosette 
round the apical pole; very small tube feet; no Polian vesicles. Five genital pores in the region (apical) of the madreporic plate. Ambulacra less petaloid. Families: Clypeastrida. Shell flattened, disc without indentations, subpentagonal. Clypeaster. Echinocyamus. Scutellida, shell flattened, often lobed or perforated, lower surface with ramifying grooves. Lobophora. Rotula.

3. Order: Spatangidea. Heart-shaped; dental apparatus absent; mouth and anus usually eccentric; fourleaved ambulacral rosette and four genital plates; without Polian vesicles. Madeporic plate interradiate. Families: Spatangide, mouth transverse or reniform. Spatangus. Schizaster. Amphidotus.

Appendix: Fossil forms with simple ambulacra: Galeritide, mouth central, shell globular or subpentagonal, a single apex. Dysasterida, mouth eccentric, shell ovoid, two apices, towards which the bivium and trivium converge.

III Class: Ophiuroidea. The brittle stars have a general external resemblance to the Asteroidea. The ambulacra are confined to the oral side of the body ; the ambulacral grooves are covered by a series of dermal plates, the feet projecting at the sides of the arms, between the spicules on the upper surface. The arms are flexible and cylindrical, sharply distinct from the disc; they are rarely branched and can (by means of longitudinal muscles) be rolled up in the direction of the mouth. The latter is situated in the centre of the oral surface, surrounded by five oral angles, each consisting of five pieces. The alimentary canal is a simple gastric sac without cœca and has no intestine or anus; pedicellariæ are likewise wanting, the madriporic body situated in one of the buccal plates. The genital glands are lodged 
in the disk, and pour their products into genital pouches, passing directly to the exterior through inter-radial paired slits. A few viviparous Ophiuroidea do not undergo metamorphosis.

I. Order: Ophiuridea. Arms unbranched; ambulacral furrows covered with plates, genital clefts ordinarily five, habits creeping. A. Oral clefts armed, no palæ angulares (teeth-like processes): Obhiodermatida, disc granulated. Ophiura. Ophiolepida, disc scales naked. Ophiolepis. Ophiopus. Amphiurida, disc rugged and scaly. Amphiura, Ophiopholis. Ophiomyxida, disc naked. Ophiomyxa. Oral clefts with palæ angulares: Ophiocomida, disc covered with solid plates. Ophiocoma. B. Oral clefts unarmed. Ophiothricida, radial plates very large. Ophiothrix.

2. Order: Euryalidea. Arms simple or branched, and capable of being rolled up towards the mouth, without plates. No spines, but tufts of papillæ on the ventral surface of the arms; ten genital slits. Astrophyton. Asteronyx.

IV CLASS: Asteroidea. (Star-fish.) Echinoderms with dorso-ventrically compressed pentagonal or starshaped body; ambulacra restricted to the oral half. The skeleton is made up of plates or thick rods, composed of a dense calcareous network. A deep groove radiating from the mouth to the end of the ray masks the position of each ambulacrum, laterally supported by two series of ambulacral ossicles connected by transverse muscles and articulated together like vertebræ in the middle line or roof of the grove, with spaces between their lateral processes for the passage of the vessel connecting the ampullæ with the radial vessel and the tube feet. The ambulacral nerve and canal are situated out- 
side the ossicles. At the circumference of the oval disc the ossicles of the ambulacra, smaller, and closely united together form a pentagon, the angles of which correspond to the ambulacral grooves, round the œsophagus. The joined outer ends of the pair of ambulacral ossicles nearest the mouth project on the oval side and are armed with strong spines, covered with pedicellariæ, small, pincer-like bodies, which during life twist and snap about. The wall of the body upon the aboral face and the sides of the rays is also armed with spines, to which pedicellariæ are attached. Mouth always in the centre of the ventral surface, in a pentagonal or star-shaped depression, surrounded by stiff papillæ. Five pairs of Polian vesicles project from the circumoral canal; the madreporic canal branches off from the latter opposite one of the inter-radial folds; taking a sinuous course, it passes to the aboral surface, terminating beneath the madreporic body. Lines drawn from the mouth along each ambulacrum are termed radii; the regions between the ambulacra are inter-radial. Anus usually present at the aboral pole. Madreporic plate and genital pores inter-radially upon the aboral surface. Multi-lobed, branched diverticula of the stomach extend into the cavities of the anus, likewise the generative organs. Some are developed within the brood pouches of the mother; the majority pass through frẹe larval stages. They all possess great powers of regeneration. Live on rocky coasts.

I. Order: Asteriidea. Ambulacral feet end in broad suctorial discs, arranged in four rows. Asterias. Heliaster. Anasterias.

2. Order: Echinasteridea. Two rows of cylindrical ambulacral feet. Families: Solasterida. Dorsal skeleton 
reticulate. Acanthaster. Solaster. Echinaster. Linckiada: dorsal skeleton of longitudinally arranged, or rounded, or quadrangular vesicles; integument granulated. Ophidiaster. Linckia. Goniasterida: dorsal and ventral marginal plates very distinct. Pentagonaster. Goniodiscus. Asterinida: skeletal vesicles imbricated. Asterina. Palmipes.

3. Order: Astropectinidea, ambulacral feet conical and without suctorial disc. Families: Astropectinida, skeleton of paxillæ. Astropecten. Luidia. Ctenodiscus. Pterasterida. Integument supported by spines, radiating from the prominent skeletal ossicles. Pteraster.

4. Order: Brisingidea. Body shaped like an Ophiuroid. Rays long, distinct from disc with only a narrow internal cavity. Brisinga.

V CLASS: Holothuroidea. (Sea cucumbers.) Vermiform Echinoderms. The body-wall consists of an external cellular ectoderm, covering a layer of connective tissue, within which are circular and longitudinal muscular fibres, arranged in five bands and attached anteriorly to a corresponding number of the pieces of a calcareous œsophageal ring (composed of ro or 12 separate ossicles). The Holothurians exhibit bilateral symmetry and resemble greatly the Gephyrea. The ambulacral feet may be either confined to the three rays of the trivium, or uniformly distributed over the surface of the body (especially the ventral side) or wanting altogether. Contractile tentacles surround the mouth, communicating with the water vascular system and representing specially modified ambulacra. The stone canal hangs freely in the body cavity, ending in a calcareous apparatus the madreporic plate. Respiratory trees and excretory glands (Cuvier) may be present at the end of the 
intestine. The generative organs consist of branched cœcal tubuli, whose duct opens dorsally near the mouth. They are of separate sexes, except Synapta. Development usually direct. The Holothurians bury themselves in the sand near the coast. They likewise possess great powers of regeneration:

I. Order: Apneumona. Respiratory trees and $\mathrm{Cu}$ vierian organ wanting; mouth and anus at opposite ends of the body; five ambulacral furrows; hermaphrodites. Families: Synaptide. Without pedicels. Synapta. Chirodota. Oncinolabida. Without pedicels. Echinosoma.

2. Order: Tetrapneumona. Four respiratory trees; body flask-shaped; mouth and anus at the same end; the former surrounded by ten tentacles and ten calcareous plates, the latter by as many papillæ and plates. Only genus: Rhopalodina lageniformis.

3. Order: Dipneumona. Two respiratory trees; $\mathrm{Cu}$ vierian organs present; mouth and anus polar; pedicels in a single row. Families: Liodermatida. No pedicels; tentacles varying. Liosoma. Dendrochirote, tentacles branclied. Thyone. Cucumaria. Psolus. Aspidochirote, tentacles shield-shaped. Holothuria.

Organization of Echinodermata. The primitive ancestral type of the Echinodermata is most probably represented by the stalked Cystidea, for it must be assumed that the influence of the sessile mode of life produced, just as in other groups, the radial structure. Their form is spheroid and in the simplest cases without brachial elongations. The protecting polygonal plates exhibit at first an irregular arrangement without any indication of radition. However, five radial furrows extend from the mouth, resembling the ambulacral grooves upon the disc 
of a Crinoid or Asteroid. A continuation of the sessile mode of life largely aided in completing the radial structure, until a type was reached similar to the following fundamental form. The body represents a spheroid with the principal (long) axis somewhat shortened and the poles flattened and dissimilar; the one (oval) containing the mouth, the other (anal) the anus. Five planes passing through the long axis of this spheroid will divide the body each into two bilaterally symmetrical halves. Thus the meridians arise which are separated from one another by equal intervals. Five alternate ones, called the principal rays or radii, contain the most important organs (nerves, vascular canals, ambulacral feet, etc.), while the other five meridians constitute the intermediate rays or inter-radii, also containing certain organs. But only the regular Echinoderms present a pentamerous radial arrangement with complete radial and interradial symmetry; however, since certain organs always remain unpaired; symmetry is, even here, not perfect. When one of the rays differs in size from the others an irregularity arises, the plane of the unpaired ray forming a median plane, on each side of which two pairs of equal rays are repeated. These form the right and left sides of the body, whilst the unpaired radius constitutes the anterior, the paired radius the posterior end; the apical pole represents the upper surface, the oral pole the under surface. In the irregular Sea-urchins this symmetry becomes still more perfect, inasmuch as the anus occurs on the ventral side of the unpaired inter-radius Clypea. strdea), or both poles (sometimes only the oral) are shifted in the direction of the unpaired radius. thus becoming eccentric (Spatangida). The distribution of the organs of locomotion (ambulacra) along all the five rays 
is of rare occurrence (in only a few regular Echinodermata). The oral pole usually becomes the ventral surface to which the organs of locomotion are confined. Irregular Echinodermata move in the direction of the unpaired ray, which causes the shifting of the oval pole in that direction, leaving the two posterior (bivium) radii to form the ventral surface. In the case of the Holothurians which obtained a cylindrical form by an elongation of the axis, the unpaired radius with its interradius marks the dorsal and ventral surface. The body is compressed in such a manner that three radii (trivium) with their organs of locomotion are placed on the ventral surface. In other cases the radii may become two or three times as long as the inter-radii until the body assumes the shape of a star which may be either flat or arched. (Compare classification.)

The cellular ectoderm of the body of the Echinoderms is provided with a thin cuticle, bearing numerous cilia. Beneath this lies a mesoderm containing connective and muscular elements, in which calcareous deposits are lodged. These give rise to a solid, more or less movable skeleton, which constitutes an important characteristic of this group. A ciliated epithelium lines the perivisceral cavity. The separate elements of the skeleton are the ossicula, the spines attached to them by ligamentous fibres, and the calcareous structures contained in the pedicellaria. On the antambulacral wall (of the Asteroidea) the ossicula (or plates) are generally elongated rods of very unequal lengths, with open meshes between and bearing different processes. Along the margin there is usually a row of larger calcareous plates, the superior marginal plates. On the oral surface we distinguish besides the internally placed ambulacral ossicles, the inferior marginal vesicles, 
the adambulacral plates, and the inter-ambulacral plates; the two last correspond to the inter-ambulacral plates of the Echinoidea (compare classification), but are disposed along opposite sides of adjacent arms. The spines of the Sea-urchins are moved laterally by special muscles developed in a soft superficial integumental layer. As to pedicellariæ compare the notes given under the special classes. Around the mouth of the Sea-urchin and on the dorsal surface of the Starfish are small transparent bodies, sphcridia, which are probably sense organs. In the Spatangidæ there are peculiar bands upon the upper surface, the fascioles or semitce, which bear bristles with cilia (cavula). In the Holothuroidea the skeletal structures are confined to isolated calcareous bodies, embedded in the integument and resembling latticed plates, wheels or anchors. The dermal muscular system consists here of five pairs of longitudinal muscle-bundles surrounded by a layer of circular muscular fibres which line the internal surface of the integument.

Perhaps the chief characteristic of the Echinodermata is the possession of the peculiar water vascular system and of the distensible ambulacral feet connected with it. It consists of the circumoral ambulacral vessel, lying close to the ossicles to which the margins of the oral membrane are attaclied, and of five radial canals extending into the rays. Along opposite sides of the radial canal numerous short branches (internally ciliated) pass from it, each opening between the ambulazral ossicles into the neck of a contractile muscular sac (ampulla), situated in the interior of the ray. The neck of each ampulla passes in opposite directions into one of the ambulacral feet (pedicels), which are the lateral appendages of the five or more radial trunks, thus affording a communication 
between them and the circumoral canal. They control by means of a water current the contraction and distention of these feet, enabling them to fasten themselves by means of their sucking discs, and to move (in most cases) the body in the direction of the radii. The distribution of these feet, and the formation of an ambulacral and antambulacral zone, has been indicated in the classification. The circumoral canal of the Holothurians gives off anterior branches to the tentacles round the mouth. As each enters its tentacle, it dilates and sends down a short cœcal prolongation on the outer side of the calcareous ring. There are four kinds of ambulacral feet in the Spatangidea. They are either simple locomotive organs, with or without suctorial discs, tactile feet with papillose extremities, or gill-like, more or less pectinated appendages, arranged over rosette shaped areas. In the Clypeastridea the petaloid portions of the ambulacra possess both branchial and delicate locomotive (with suckers) pedicels. Very frequently a number of small eminences, consisting of cœcal vesicles (Polian vesicles) are seated upon and open into the circumoral canal; likewise a number of racemose appendages whose function is still disputed. A stone canal (rarely more than one) proceeding from the circumoral vessel permits the communication between the sea-water and the fluid of the water vascular system. It receives its name from the calcereous deposits in its walls. May be suspended within the body and take up fluid through the pores in its walls, or it may end in a porous, calcareous plate (madreporic plate or body), which is inserted in the external cavity of the body. Its position varies considerably, as indicated in the classification.

The alimentary canal of the Echinodermata consists of 
œsophagus, stomach and rectum. The mouth is often surrounded by projecting skeletal plates provided with spicules. In the Cidaridea and Clypeastridea a powerful masticatory apparatus is developed known by the name of "Aristotle's lantern." It consists of five hollow, wedge-shaped, calcareous pieces-the alveoli-each of which is composed of two halves united together in the middle line; each half again consists of a superior (epiphysis) and an inferior principal portion. From each alveolus projects a long pointed tooth, and strong muscular fibres (inter-alveolar) unite the aiveoli into a one shaped apparatus; the epiphyses of each pair of alveoli are connected by long radial (articulated) pieces, the rotula, each of which articulates internally with a slender arcuated rod which terminates above the rotula in a free bifurcated extremity, the radius. The alveoli and teeth are interambulacral, the radii and rotulæ are a mbulacra1. Protractor muscles arise from the interambulacral region of the oval edge and are inserted into the upper part of the alveoli; slender oblique muscles of similar origin are inserted into the radii; transverse muscles connect the radii together and retractor muscles from the ambulacral arches are inserted into the oval ends of the alveoli. The œsophagus of the Asteroidea opens into a wide stomach enlarging into five cardiac sacs whose walls are composed of many sacculi. Each cardiac sac may extend a short distance into the cavity of the corresponding ray. On the aboral side of these diverticula the alimentary canal abruptly narrows and then dilates again into a pentagonal pyloric sac whose angles divide and pass as parallel multilobed diverticula (liver) along either (aboral) side of each ray. Pairs of mesenteric folds fasten the alimentary canal to the body wall. The five diverti: 
cula of the short rectum which fall in the inter-radii are much shorter and perhaps perform the functions of nephridia. The narrow intestine of Comatula, Sea-urchins and Hothurians is much increased in length and either coiled or folded. The anus of all Echinoderms is usually placed at the centre of the apical pole, rarely in an inter-radius on the ventral side.

The true vascular system of the Echinoderms consists of two ring-like vascular plexus, one around the œsophagus and one on the aboral surface; the former sends off branched radial vessels, the latter supplies the stomach and genital organs. Both rings are connected by a socalled heart (connected with the stone canal in the Asteroidea) composed of a plexus of contractile vessels. In the Holothurians only the œsophageal circular vessel with two trunks, giving off branches to the intestine, has been observed. A watery fluid containing nucleated cells which exhibit amœboid movements fills not only the blood-vascular system, but also the vessels and the peritoneal cavity of the body and rays. The vascular rings are the result of the metamorphosis of saccular diverticula of the alimentary canal (cœlom), which have encroached upon and largely diminished the primitive body cavity.

The function of respiration is largely performed by the ciliated surface of the organs suspended in the body cavity and of the external appendages, which keep the traversing sea water in constant motion. Special organs of respiration are the ambulacral branchice of the irregular Sea urchins, the dermal branchice (simple tubes) covering the whole surface of the Asteroidea, the five pairs of branched tubes surrounding the mouth of Echini, and especially the so-called respiratory trees of the Holothuri- 
ans, two large tree-like branched tubes, which open by a common stem into the cloaca. The functions of the respiratory tree of the Starfish is still a matter of dispute.

The central nervous system of the Echinodermata consists of band-like thickenings of the ectoderm, which in the Asteroidea are situated, one in each ray, beneath the epidermis of the ambulacral groove, external to the blood vessel and water-vascular canal, sending off numerous fibres to the muscles of the spines, the ambulacral feet, pedicellariæ, etc. Followed to the base of the rays they reach the oral disc at the periphery of which they divide and, skirting the margin of the disc, join to form a subpentagonal ring (containing ganglion cells) round the mouth; in the opposite direction they end upon the eyes and their tentacles. The eye at the ventral termination of each ray represents a spherical protuberance, the conical surface of which is covered by a membrane which covers a number of conical simple eyes, each consisting of a red mass of pigment around a refractive body and a nervous apparatus. In the Cidaridea they represent five tentaclelike prominences with nerve endings, situated on special plates (ocular plates) at the apical pole. The tentacle-like ambulacral foot at the end of each ray (in Asteroidea and Ophiuroidea) seems to be of tactile character, just as the tentacles of the Holothuroidea and the tactile feet of the Spatangidæ.

The number and position of the genital organs generally correspond to the radial structure. The five-lobed ova or testes of the Echinoidea are situated in the interradii immediately beneath the genital plates around the apical pole through which they open; in the irregular Spatangidæ there may be only two or three glands the 
generative organs of the posterior inter-radius being always absent ; in the Asteroidea the five pairs of genital glands have the same interradial position, extending sometimes into the rays, and opening through numerous pores on the interradial dorsal side. In the Ophiuroidea ten lobed generative glands are developed around the stomach (comp. classification); those of the Crinoidea are conceáled in the arms and pinnules; those of the Holothuroidea are reduced to one branched gland the duct of which opens on the dorsal side of the interior pole. The organs of the two sexes are in all cases extremely alike; they only differ somewhat in color, the seminal fluid being white, the ova red or yellow. Sexual differences or dimorphism is very rare. Ova and spermatazoa first unite in the sea water, after ejection from the parental body. Internal fertilization only occurs in several viviparous species of Amphiura and Phillophorus (Claus).

The development of the different classes of the Echinodermata shows their close relationship. It manifests itself in four stages: (I) in the formation of the primary germ layers and of the mesenchyma, as well as of the beginning of mouth and anus; (2) in the rise of enterocœlum and hydrocœlum; (3) in the development of the typical larval forms; and (4) in the transformation of the larva into the Echinoderm. Segmentation is always total and nearly equal resulting in a ciliated blastula. From this a typical invagination gastrula is developed; mesenchyma cells separate from the invaginated part (Antedon, Astropecten, Synapta). In the Echinoidea and Ophiuroidea the mesenchyma arises before gastrulation, but likewise from the entodermal portion of the blastula. The mesenchyma has the same origin 
as the mesodermal structures, which separate from the cœlom as cœlom sacs. The next process is the constriction of the embryonic structures of body cavity and water-vascular system, which arise as diverticula of the cœlom. Ludwig calls them enterocœlom and hydrocœlom; Selenka uses for both the name vaso-peritoneal vesicle. They separate into two enterocœla and the hydrocœlom, the latter of which opens externally by a dorsal porus. The blastoporus becomes wherever it is retained, the anus. The mouth originates through the union of cœlom and ectoderm; different modes of life, however, condition variations in the formation of mouth and anus. Although the external form of the different larvæ varies greatly, there are nevertheless certain external essential points of resemblance, among which the common ciliated band is most prominent. Thus the larva of Antedon, which differs from all others in form, resembles the so-called pupa of the Holothuroidea in the possession of five ciliated bands. Even the development of the various systems of organs shows marked coincidences, so, e. g., the water vascular system, the nervous system and especially the muscular structure. The rise and final union of the ambulacral and anti-ambulacral surfaces are of the very same character in the Brachiolaria (Asteroidea) and Pluteus (Ophiuroidea) larvæ. There exists a certain similarity between the larvæ of Crinoids and Holothurians with regard to the formation of tentacles at the base of an oral vestibulum produced by an ectodermal invagination. Nothing definite can be said in reference to the various calcareous skeletons.

All Echinoderms possess a radial structure but their larvæ are of a bilaterally symmetrical structure, both internally and externally. The transformation or meta$\mathrm{M}^{*}$ 
morphosis of the latter into the former is simplest in the Holothuroidea. The lobed processes of the larva (Auricularia) disappear, the ciliated band divides into separate pieces, which change their longitudinal into a transverse position. The margin of the larval body becomes even and the larva assumes a cylindrical shape; the pieces of the ciliated bands unite laterally into five rings surrounding the body like loops (pupa stage); four of these pieces unite into a ring around the mouth and gradually move into the interior of the larva, forming finally the œsophageal nerve-ring. After this the water-vascular system differentiates by secondary anterior and posterior evaginations of the water-vascular ring; finally the ambulacral feet make their appearance, being evaginations of the ambilacral radial vessel, and the tentacles protrude through the mouth opening, the animal begins to move about.

It is difficult to show their phylogenetic relationship. Various theories have been advanced, but none is satisfactory. It is most likely that palaeontology furnishes the best solution of the question. The relation between modern Echinodermata and the Cystidea has been indicated above. However, no one can tell where the bilateral ancestors of the radial type may be found. The trochophora larva shows certain resemblances, but the difference in the distribution of the cilia and the abscence of a vertex plate make a definite decision very difficult. It is however firmly established that the development of the body cavity as it takes place in the Annulata and that of the Echinodermata indicate the same origin, so that the mesoderm of the Annulata and that of the Echinodermata must be considered as homologous. There are even indications which establish the relation 
of the Echinodermata to segmented forms. (Korschelt and Heider.)

Appendix: Enteropneusta. The isolated genus Balanoglossus is generally classified under the above head and forms, together with the Echinodermata, Hatschek's type Ambulacralia. Prof. E. D. Cope and others assign it as superclass I (Hemichorda) a position among the Vertebrata. As such it consists of but one class the Enteropneusta with but one order the Helminthophya, represented by one family the Balanoglossida, including species of worm-like form which burrow in the soil of the sea coast below high tide. Balanoglossus clavigerus (Della Chiage). B. minutus (Kowalewsky). B. Kowalewskii (A1. Agassiz). B. Brooksii (Bateson). $B$. salmoneus (Giard). B. robinii (Giard).

Balanoglossus represents an elongated vermiform body consisting of a distinct so-called anterior gland or proboscis, followed by a muscular collar and the gill region which gradually passes into the posterior portion of the body. Proboscis and collar serve as locomotory organs (boring themselves by peristaltic motions through the sand, which passes through the alimentary canal) and are therefore composed of external circular and internal longitudinal muscles. Cavities present in the two organs between the longitudinal muscles and the connective tissue cells communicate through dorsal pores with the outside, allowing the influx of water. On that account these cavities have been compared with the watervascular system of the Echinodermata. Others maintain that they are simply excretory organs, which might by true on account of the (excretory?) glandular structure present in the proboscis. The alimentary canal, beginning with the broad mouth opening immediately beneath 
the proboscis, extends in an almost straight line through the body. Of great importance are its diventricula. A dorsal evagination protrudes into the base of the proboscis. Between the ventral wall of the former and the epidermis of the latter the anterior part of the so called proboscis. skeleton is situated, whilst its two posterior branches, situated in the folds of the alimentary canal, clasp the foregut. Bateson and Köhler compare this structure to the chords of the Vertebrata. That portion of the alimentary canal which follows the collar region contains dorsally the branchial diverticula, usually situated along both sides of the median region and lined by a ciliated epithelium. They open through passages on the dorsal surface, and their position is easily recognized by the transverse arches connecting the individual pairs of diverticula; a chitinous skeleton supports their walls. The water passes from the mouth through the foregut in to the branchiæ and through the pores outward. Some distance behind the branchial region the alimentary canal evaginates into hepatic diverticula, which cause a bulging out of, the external integument. Median dorsal and ventral mesenteris fasten the alimentary canal and divide the body-cavity into a right and left partition (in some cases fusing dorsally). The body cavity of the collar is different in structure and origin from that of the trunk, being however, largely reduced by the accumulation of connective and muscular tissues, whilst the latter (maintained by Spengel and denied by Köhler) largely remains, its walls being composed of the longitudinal and circular muscles of the somatic and splanchnic layers.

The blood-vascular system consists of two principal vessels, one situated along the dorsal median line (current 
anteriorly) and the other along the ventral median line (current posteriorly); both give off branches at regular intervals to the body wall and the organs. Kovalewsky maintains also the presence of two lateral vessels, which receive branches from the alimentary canal and the gills. The nature of the saccular structure at the floor of the proboscis, considered by some as the central organ of the blood system, is still disputed. The central nervous system consists of a thick cord, situated in the median region of the collar. Bateson maintains that it contains a central canal similar to that of the spinal cord of Vertebrates, others however affirm only the presence of irregular interstices; its interior fuses at the posterior (and interior) end with the epithelial cells of the body wall. This central cord gives off a strong nerve which extend along the dorsal median line of the body. It branches behind the collar and uniting below in the region of the first pair of branchiæ, these nerves continue towards the posterior end of the body as the ventral median nerve. The genital organs of Balanoglossus lie either within or back of the gill-region. The sexes are separate; male and female organs are of the same form and occupy the same position in either sex; they consist of simple or branched tubes lying along the side of the body and opening in rows along the dorsal surface. In some forms two median rows occur, situated between the branchial diverticula and the dorsal vessel. The portion following the branchial region is sometimes very highly developed and differentiated as a special genital region.

The genital products are ejected into the water through the ruptured body wall; after which fertilization takes place. Segmentation is total and nearly equal, resulting in a blastula, followed by a typical invagination gas- 
trula. Development is either direct from the egg to the adult, or it passes through a larval stage, whose form resembles the larvæ of the Echinodermata. Joh. Muiller named it Tornaria. At an early stage an unpaired evagination of the cœlom arises, which in its structure is said to correspond to the water-vascular vesicle of the Echinoderms, opening to the outside through a dorsal process. The proboscis, whose internal walls are formed by the so-called water-vascular vessel, has therefore been looked upon as the only remnant of the ambulacral tentacles. However, it is difficult - to carry the comparison any further; the characteristic ciliated band of the Echino. derms exhibits an entirely different arrangement in Tornaria. The presence of a vertex plate with its eyes and nerve cord rather suggests a relation of the latter to the trochophora. The existence of gills led to the assumption that Balanoglossus might belong to the Chordata (Balfour). A comparison with Amphioxus showed certain relations with regard to the gills, the alimentary diverticulum with its skeletal body (chorda) and the mode of origin of the nervous system. A further remarkable resemblance exists between the anterior cœlom sacs of Balanoglossus and the anterior cœlom diverticula of Amphioxus, one of which enlarges and leads through a ciliated canal outward, thus corresponding exactly to the so-called water-vascular vesicle or anterior cœlom sac of the Balanoglossus larva. However, all these phenomena do not furnish a sure basis for the above assumption (Korschelt and Heider). 


\section{TUNICATA.}

A remarkable and in many respects isolated groups of marine animals of bilateral, saccular or barrel-shaped form, which owe their name to a gelatinous or cartilaginous enrelope or mantle completely surrounding the body. Since Kowalewsky's splendid discoveries, in I866, the Tunicata have frequently been classified among the Vertebrates under the superclass of Urochorda on account of the presence of a notochord-like skeletal axis in the tail. Their respiration is pharyngeal; a distinct saccular heart occurs. The branch consists of both free and composite, fixed and free organisms.

I CLASS: Ascidiæ. Mostly fixed form enveloped in a tunic of saccular shape. The inhalent (mouth) and exhalent pores are close together. The former, possessing in many cases four, six or eight marginal lobes, can be closed by a sphincter muscle; the margin of the latter, situated dorsally behind the mouth, is often similarly divided and can also be closed. Branchial sac large, containing a circle of simple tentacles. Alimentary canal elongate, often causing a constriction of the body into thorax and abdomen. They either remain solitary, and are then of considerable size, or they form colonies without being enveloped in a common mantle; or numerous individuals live in a common mantle, arranged around a central opening, which leads into the openings of individual groups.

I. Order: Larvacea, Small, free-swimming, pelagic 
Ascidians, with large swimming tail containing a skeletal axis (urochord). Branchial sac an enlarged pharynx with two ventral ciliated openings (stigmata); heart with two slits but no vessels. Anus opens ventrally in front of stigmata. No cloacal chamber. Nervous system consists of cerebral ganglion with three constrictions, and a long nerve cord running down to the tail along the left side of the urochord. They resemble the larvæ of other Ascidians. Some have a shell-like covering. Reproduction without budding or metamorphosis. Family: Appendiculariide, with short body, long tail and straight endostyle in Oikopleura (Appendicularia); or with long body (with anterior ectodermal hood), short tail and recurved endostyle in Fritillaria; or without heart, endostyle and intestine in Kowalevskia.

2. Order: Ascidiacea. Sessile solitory or free swimming compound ascidians; adult without tail and notochord; with well-developed permanent test, increasing with the age of the individual. Branchial sac large and perforated by numerous stigmata which lead into the peribranchial cavity and open to the exterior by the atrial aperture. Reproduction frequently by budding; in other cases embryo with tailed larva.

I. Suborder: Ascidice simplices. Solitary forms large and surrounded by a very thick and hard cartilaginous mantle with protuberances of various kinds. The colonies or social Ascidians have a common circulation, but each individual has its own test of a transparent hyaline consistency. I. Family: Clavellinida, simple Ascidians which reproduce by budding to form colonies, the buds arising from a common branched stolon; body sometimes divided in three regions. Ecteinascidia. Clavellina. Perophora. 2. Family: Ascidiide, solitary sessile Asci- 
dians of considerable size; rarely aggregated, and then without common mantle and blood vessels; mantle parenchyma gelatinous; branchial sac not folded, its apertures eight-lobed. Hypobythius. Ciona. Ascidia. Rhodosoma. Abyssascidia. Corella. Corynascidia. Chelyosoma. 3. Family: Cynthiida, solitary sessile, with leathery mantle parenchyma; branchial sac longitudinally folded, its aperture four-lobed. Styela. Bathyoncus. Cynthia. Boltenia. Culeolus. Cheveulius. 4. Family: Molgulida, solitary forms, sometimes free; mantle parenchyma, incrusted with sand; branchial sac longitudinally folded, its aperture six-lobed. Molgula. Eugyra. In Anurella, direct development takes place.

2. Suborder: Ascidice compositce. Sessile Ascidians enclosed in a common mantle layer and grouped around a common cloaca (Botryllus), forming a soft, brightcolored colony; mantle mass permeated by vascular canals. I. Family: Distomida, divided into thorax and abdomen, vas deferens not spirally coiled. Distoma. Distaplia. Collella. Chondrostachys. 2. Family: Calocormida, colony not fixed. Colocormus. 3. Family: Didemnidce, mantle-parenchyma with calcareous spicules, vas deferens spirally coiled. Didemnum. Leptochinum. 4. Family: Diplosomidce, mantle parenchyma reduced, rarely containing spicules; vas deferens not spirally coiled. Diplosoma. 5. Family: Polychinida, zooids divided into thorax, abdomen and postabdomen, numerous testes. Pharyngodictyon. Polychinum. Aplidium. Amaroncium. 6. Family: Botryllide, most complete colonies, viscera of the simple undivided body side by side of the respiratory cavity, Botryllus. Botrylloides. 7. Family: Polystyelide, zooids not grouped in systems; branchial and atrial apertures four lobed. Thylacium. Goodsiria. Chorizocormus. 
3. Suborder: Ascidice Salpiformes. Free-swimming pelagic colonies, shaped like a thimble or hollow cylinder closed at one end. The numerous individuals, of which these colonies are composed, are arranged at right angles to the long axis of the colony; the branchial apertures open on the outer surface, the atrial (exhalent apertures) on the inner into the common cloaca. The large branchial sac occupies the greater part of the body. The nerve ganglion contains a small pigmented sense organ. The alimentary canal is placed posteriorly to the branchial sac opening into a large peribranchial cavity, and the intestine and ovary being compressed together so that they resemble a nucleus. One ovunı is matured at a time. In all these respects they resemble the Salps. Sexual reproduction and budding take place in the same individual, the latter by means of a stolon, beginning at the posterior end of entostyle; it is very complicated. In sexual reproduction the embryo (cyathozooid) is developed within an ovarian sac, but produces by budding from a stolon a group of four ascidiozooids, from which the colony gradually increases. Only family: Pyrosomidae (name from phospborescent glands on either side of the anterior end of the branchial sac). Pyrosoma.

II ClAss. Thaliacea. Free swimming transparent pelagic forms, either simple or compound (usually in double rows); adult always without tail and notochord. The body is cylindrical or cask-shaped. Mantle apertures at opposite ends of the body. Mouth usually a transverse slit with movable lips. The band-shaped gill, situated in the large respiratory cavity has either two large (Salpa) or many small apertures (Doliolum), leading to a single peribranchial cavity, into which the anus opens. Alimentary canal, heart and generative 
organs are closely packed together at the ventral posterior end, forming a brightly colored mass, the so-called nucleus. The nervous ganglion situated along the middle of the dorsal margin sends off numerous nerves to the body and sense organs. Eight or nine circular muscle bands surround the body and effect rapid locomotion, which together with the highly developed nęrvous system makes this order far superior to the Ascidians. Alternation of generations occurs and may be complicated by polymorphism.

I. Order: Hemimyaria. Body more or less fusiform, with the long axis antero-posterior and the branchial and atrial aperture nearly terminal. Anterior opening with a valve-like closable lips. Gill, a median band extending from the ganglion to the oval region. Freeswimming solitary forms alternate in their sexual condition with colonies budded from stolons and united in chains; proterogynous. The single ovum develops into an embryo within the brood-pouch of the viviparous mother by means of a placenta, and becomes a single Salpa (asexual). I. Family: Salpida. Salpa. 2. Family: Octacnemida. Octacnemus.

2. Order: Cyclomyaria. Body cask-shaped, branchial and atrial apertures surrounded by lobes. Gill rather large, occupying the anterior dorsal half or more of the body, stigmata usually represented by two lateral rows in the posterior part only. Alimentary canal not com pressed into a nucleus. Ovaries with more than one egg. Testes and ovaria ripen at the same time. Complicated - alternation of generations. Never form colonies. Family: Doliolide. Doliolum. Anchinia.

Organization and development. The form of the body of the Tunicata exhibits in the various divisions such 
remarkable modifications that a mutual relationship can scarcely be recognized. In the lowest forms the body consists of two divisions, the anterior enclosing the most important organs and exhibiting bilateral symmetry, and the posterior or tail-portion projecting ventrally at an angle from the latter and appearing like a simple appendage. In the highest Tunicates (Doliolum) a similar process is found only in the young which seems to prove that the ancestral type possessed such a tail-like region. The power of locomotion is lost with the propelling tail, the adult becomes sessile, and its external appearance simplified, whilst the internal structure becomes more complicated. A special chamber with the function of a cloaca arises into which the atrial aperture leads. The free-swimming Hemimyaria and Cyclomyaria propel themselves by means of their body walls, the orifices assume extreme anterior and posterior positions. The investment of the body consists, in its primitive condition, of a single layer of flattened cells formed from the ectoderm and largely representing the body-wall. In the lowest Ascidians the cells around the inhalent orifice enlarge and secrete a gelatinous substance, which gradually envelopes a part or the whole of the body serving as a protecting envelope or test. In the higher Tunicata a firm cuticular secretion is produced by the whole body surface, varying from the softness of jelly to the hardness of cartilage and assuming the characters of connective substance, in which cellulose is embedded. This is the outer mantle. Complications of the mantle arise through the entering of numerous blood-vessels (Ascidia, L.), and in Chevreulius by the development of two valves, movable like shells. In colonies only mantle may enclose all the individuals, Also numerous other 
integmentary formations may arise, such as unicellular gland, hair-like processes, calcareous spicules, etc. The axial organ present in the tail of the Appendiculariæ may be looked upon as a skeleton, composed of cells which secrete a homogeneous elastic chord enclosed in a continuous sheath. This organ is homologous (in position) with the chorda dorsalis of the Vertebrata, a fact which justifies the classification of the Tunicata together with the Vertebrata under the common head of Chordonii (Hatschek). The muscular system is chiefly developed around the respiratory cavity, consisting in the Ascidians of three layers, an external and internal longitudinal, and an internal circular layer; in the Salps of band-like rings of muscles embedded in the body wall, serving also functions of locomotion; in the-Appendiculariæ they are confined to a dorsal and ventral band of the tail. The central nervous system arises from a differentiation of the ectoderm and occupies a dorsal position, which distinguished the Tunicata from all other invertebrate animals. It consists of an anterior ganglion, divided into three consecutive lobes, produced by an unequal thickening of the wall of the original ectodemal tube; the foremost is (in Ascidiæ and Salpæ) in close connection with the origin of the visual organ. Peripheral nerves pass out from the anterior ganglion, encircling the inhalent aperture; others pass to the muscles, viscera and sense organs. In the larval Arcidians and the adult Appendiculariæ the nervous system is made up of an anterior elongated ganglion with three dilatations and a chord which passes posteriorly to the end of the tail, where it forms three ganglionic swellings, the first of which is most constant and regarded as the central organ of the nervous system. With the atrophy of the 
tail the caudal division of the nerve-centre disappears and the anterior portion becomes more elaborate. The lobes of the oval and atrial apertures and the tentacles serve as organs of sense. A more differentiated organ of sense is the so called ciliated groore, clothed with flagellate cells and situated either in front of the ganglion or on that surface of the ganglion which is turned towards the branchial chamber; it is considered as an olfactory organ. An auditory vesicle is present on the left side of the ganglion (paired in Pyrosoma). Eye spots have been observed on the lips of the large openings in the simple and compound Ascidians. In Salpa the eye is represented by a spherical process with a brownish-red pigment spot and numerous rod-shaped structures. The alimentary canal (arising from the entoderm) forms the part of the body which is most peculiar in the Tunicata. The anterior portion of the foregut is transformed into a respiratory organ similar to that of the Enteropneusta. The anterior mantle-opening or month leads into this cavity, admitting the water which not only brings nutrient matter, but serves also for respiration, finding its exit through special openings (stigmata arranged metamerically) in the wall of the pharynx (sometimes a special peribranchial chamber surrounds the latter) whilst the food particles are directed to the alimentary canal proper by special arrangements. The special form of the respiratory organ presents numerous modifications of systematic value (comp. classif.). A ciliated groove bounded by two folds extends along the middle ventral line of the latticed branchial sac (in Ascidians) between the mouth and the œsophagus. The glandular walls of this groove are called the endostyle. Near its foremost extremity ciliate tracts commence which embrace the entrance to the res- 
piratory chamber and continue dorsally either to the œsophagus or to the neighborhood of the great ganglion, taking a spiral turn on the way or ending in a ciliated groove, (similar organ in Balanoglossus). The alimentary tract succeeding the respiratory cavity consists of a ciliated funnel-shaped œsophagus, of a stomach usually provided with hepatic diverticula and of a small intestine forming a loop and opening into the cloacal cavity. The blood-vascular system of the Appendiculariæ consists of a heart, a short sac with its end attached to two cells whilst its delicate walls present two longitudinal slits placed on opposite sides. In the others vascular trunks (lacunæ) pass from the heart into a system of spaces in the body wall through which the blood passes (of special complication in the Ascidians). Of great importance are the two longitudinal vessels, one in the median dorsal line and the other beneath the ventral groove, both connected by transverse anastomosing channels placed in the wall of the branchial cavity and communicating with a number of lacunæ in the respiratory organ, over whose surface the water is continually renewed. Thus it appears that a portion of the primitive body cavity (a modified form of enterocœlom) is taken up by the blood vessels. Peculiar to all Tunicata is the alternating direction of the blood-current, produced by the heart (compare Phoronis), so that we cannot speak of an arterial and a venous division of the vascular system. Organs of excretion are only present to a very limited extend, a tubular glandular organ without openings has been found near the branchial chamber or further back in many Ascidians.

Only the Appendiculariæ possess sexual organs universally; a large number of the other Tunicata is devoid of such on account of the frequent asexual reproduction, 
which resembles the process of multiplication by budding. All the members of this branch are hermaphrodite; the genital glands, which may be either simple or complicated, are situated among the viscera in the anterior part of the body. Male and female organs may ripen their products at different times. Fertilization and embryonic development usually takes place in the cloacal chamber, the embryo within the egg membrane either leaving early through the exhalent aperture, or at later. stage of development, being meanwhile nourished by a sort of placenta.

Colonies are formed in various ways. Those of the Ascidiana are produced by means of a stolon sent forth by the parent, and composed of ectodermal and entodermal elements. It may directly grow into an organization similar to the parent, or it may produce a second bud, both together developing and producing each a new bud, and so on until eight buds are formed, when the mother dies and the young animals are left in communication with one another by means of a cloaca, constituting a rosette-shaped group. Sexual organs are only found in the colonies; persons developing from an egg never acquire such organs in the compound Ascidians. In the higher Tunicata colonies are formed by a special organ, situated either upon the dorsal surface (Cyclomyaria) of the body, or ventrally within a cavity (Hemimyaria), and called the germ-stock or stolo prolifer. In the former the buds arise from the stolon by short processes; in the latter the stolon becomes a part of the new outgrowth. An alternation of generations arises here likewise, inasmuch as the forms provided with a stolon are always permanently devoid of sexual organs, whilst the individuals derived from the stolo prolifer are 
sexual. In Doliolum, however, several generations succeed one another in the cycle of development.

The embryonic development of the Ascidians resembles that of the lower Vertebrates, especially of Amphioxus. Segmentation is total and equal, resulting in a spherical blastula which changes into an invagination gastrula, from the ectoderm of which the neural tube is developed. The axial skeletal structure arises from a double row of entoderm cells (like the chorda dorsalis). Alimentary canal, nervous system and notochord occupy an analogous position to those of the Vertebrates. The movable larva (Ascidian tad-pole).swims about freely, often producing a colony before becoming fixed. It possesses the essential characters of the Chordata, inasmuch as it has a longitudinal skeletal axis (notochord) separating a dorsally-placed nervous system from a ventral alimentary canal. After it has fixed itself it undergoes a remarkable series of retrogressive changes, which convert it into the adult Ascidian. The important conclusion drawn from all this is, that the Tunicata are the degenerate descendants of a group of Chordata. 


\section{VERTEBRATA.}

Bilaterally symmetrical animals possessing an internal skeleton (vertebral column) which traverses the longitudinal axis of the body dividing it into a number of 1netameres (primitive vertebræ). This skeleton separates a dorsal from a ventral division of the body; its dorsal processes (upper vertebral arches) enclose the nervous centres (brain and spinal cord), and its ventral processes (ribs), the digestive canal continued from a respiratory chamber and with its differentiations embedded in a cœlom. There are at most two pairs of limbs.

*I Superclass: Cephalochorda. No anterior dilatation of the nerve tube to form a (traces of a brain differentiation in Amphioxus have recently been observed by Hatschek, predicating undoubted similarities to the higher Vertebrates) brain and no specialized skeletal brain-case, notochord, a simple rod, extending from one extremity of the elongate body to the other, ending beyond the nerve-cord.

I CLASS: Acrania. Walls of the body a series of muscular segments (myotomes) not in any way fused to form a head or cranial structure; no jaws nor extremities; pharyngeal walls fissured, heart a longitudinal vessel, which gives off branchial vessels, uniting into an aorta; a liver and vena cava present.

*Compare E. D. Cope's "Paleontology of the Vertebrata." I8gr. 
Only Order: Leptocardii. Somewhat asymmetrical. Pharyngeal fissures enclosed externally by a fold of the integument, which forms a chamber (atrium) with inferior openings of the alimentary canal at opposite extremities. Amphioxus.

II Superclass: Craniata. Tubular cerebro-spinal nerve-mass, swollen anteriorly to form a brain, consisting primarily of three successive vessels, from the anterior of which olfactory organs and the eyes originate. Cartilaginous cranium or brain-case round the anterior extremity of nerxe cord, enlarging laterally to protect the brain. The cartilage is in most cases replaced by bone.

I CLASS: Agnatha. No lower jaw nor pectoral arch. Internal skeleton cartilaginous. Largest number extinct.

I. Subclass: Ostracophori. An osseous dermal skeleton with lateral limblike appendages. Extinct.

2. Subclass: Marsipobranchii. Vermiform. No osseous skeleton nor lateral limblike appendages. No extinct species known.

I. Order: Hyperotreti. Branchial fissures communicating directly with the pharynx; nasal sac perforating the palate. Myxinidce. (Hags.) Bdellostomida.

2. Order: Hyperoarti. Branchial fissures communicating with a common branchial passage which opens into the pharynx; nasal sac not perforating palate. Petromyzontida. (Lampreys.)

II CLASS: Pisces. Lower jaw and pectoral arch present. Basicranial axis not ossified; vertebral column consisting chiefly of intercentra. Limbs represented by many radiate fins, which are also present on the median lines of the body; a coracoid bone; heart with two chambers; cold-blooded; breath by means of gills; one or no occipetal condyles; no internal nares. First two 
subclasses without, second two with suspensorium of the mandible.

I. Subclass: Holocephali. No dermal cranial ossifications ; ventral claspers ; no opercular bones ; small opercular membrane; no maxillary arch.

Only order: Chimaroidei. (Sea-cats.) A single external branchial fissure; actinotrichia present; basilars, axonosts, and neural spines articulating with each other; pectoral fin pleuribasal, with three axonosts and and numerous basilars; ventrals with elongate axonosts and basilars. One pair of large teeth in the upper and two in the lower jaws. Chimara. Callorhynchus.

2. Subclass: Dipnoi. Scaly fishes with branchial and pulminary respiration, muscular conus arteriosus and spiral valve in the intestines.

I. Order: Arthrodira. Notochord persistent. Paired fins rudimentary or absent, pelvic elements double, lateral, body more or less protected by plates. Extinct. .

2. Order: Sirenoidea. Paired fins unibasal; pelvic elements fused on the middle line; body without bony plates. Ceratotida. Lepidosirenida.

3. Subclass: Elasmobranchii (Sharks). Cartilaginous fishes with large pelvic and pectoral fins, transverse mouth on the ventral side, with five pairs of branchial organs and branchial slits; muscular conus arteriosus with several rows of valves. Intestine with spiral valve.

I. Order: Ichthyotomi. Persisting notochord; paired fins unibasal and archipterygial; a basioccipital element. Extinct.

2. Order: Selachii (Sharks and Rays). Paired fins pleuribasal; no basioccipital.

I. Suborder: Tectospondyli. Body suppressed with branchial fissures, either ventral or lateral concentric 
laminæ of the vertebræ predominating over the radiating laminæ; anal fin absent. Teeth in the usual jaws. Petalontidæ. Psammodontidæ. Rajidæ. Rhinobatidæ. Trygonidæ. Myliobatidæ (eagle rays). Spinacidæ. Teeth in a produced muzzle: Pristiophoridæ. Pristidæ (sawfishes).

2. Suborder: Asterospondyli. Radiating laminæ of vertebræ predominating over the concentric; anal fin present. Teeth molariform: Cestraciontidæ, teeth separate. Cochliodontidæ, teeth confluent. Teeth with elevated cusps: Hexanchidæ. Scylliidæ. Lamnidæ. Carchariidæ.

4. Subclass: Teleostomi (true fishes). Fishes with bony skeleton, with free gills (four on each side) and an external branchial operculum. Bulbus arteriosus with two valves at its base. Optic nerves do not form a chiasma.

I. Superorder: Rhipidopterygia. Median fins each with a single bone representing axonosts. Paired fins unibasal. Extinct.

2. Superorder: Crossopterygia. Median fins with numerous axonosts. Paired fins with baseosts, pectoral axonosts distinct from baseosts. Only living family: Polypteridæ.

3. Superorder: Podopterygia. Median fins with numerous axonosts. Paired fins with baseosts; pectoral axonosts and baseosts confounded; pluribasal.

I. Order: Lysopteri. Branchiostegal rays present. Extinct.

2. Order: Chondrostiei. No branchiostegal rays; degenerate representatives of the Podopterygia, deficient in various normal ossifications, middle line of the skull covered by dermal bones. Accipenseridæ (sturgeons). Polyodontidæ (paddle-fishes). 
4. Superorder: Actinopterygia. Median fins with numerous axonosts; pectoral fins only with baseosts, confounded with axonosts, and pluribasal. They represent the finally specialized type of the true firsh. Skeletal parts of the true fins abbreviated, basilar elements sessile on the scapular; rays of the median fins distinctly devel. oped and articulated; tails usually homocercal; vertebræ, in most cases ossified.

I. Tribe: Malacopteri. Ventral fins abdominal; a ductus pneumaticus; no spinous dorsal fin; parietal bones not usually separated by supra occipital; scales usually cycloid. Represented by sixteen orders.

2. Tribe: Aconthopteri. Ventral fins usually thoracic jugular; no ductus pneumaticus; usually a spinous dorsal fin; parietal bones usually separated by the supra occipital; scales usually ctenoid. Represented by ten orders.

III CLASS: Batrachia. Lower jaw and pectoral arch present. Basicranial axis not ossified; vertebral column consisting chiefly of intercentra. Limbs consisting of one basal element, two propodials, and metapodials and digits; no median fins; lower jaw attached to a suspensorium, complex; no opercular bones; a caracoid; heart with three chambers; two occipital condyles; internal nares.

I. Subclass: Stegocephali. Basioccipital, supra-occipital, intercalary, and supra-temporal bones present; propodial bones distinct- Extinct.

2. Subclass: Urodela. Basioccipital, supraoccipital, and supratemporal bones wanting, propodial bones distinct; no urostyle.

I. Order : Proteida. An os intercalare. Palatine arch and vomer present. Family: Protida, anterior limbs short with three digits; hind limbs with two digits. Proteus. 
2. Order: Pseudosauria. A maxillary arch and vomers; no os intercalare. Cryptobranchidæ. Amblystomidæ. Salamandridæ. Amphinmidæ.

3. Order: Trachystomata. No os intercalare; no maxillary arch or vomers. Sirenide. Rudimentary anterior limbs, without posterior limbs. Siren.

3. Subclass: Salientia. Basioccipital, supraoccipetal, intercalare and supratemporals wanting; frontals and parietals connate; propodial bones connate; lumbosacral vertebræ united into a urostyle.

Only order: Anura. Vomers and palatopterygoid arch present.

I. Aglossa. Internal nostrils opening together on the middle line; no tongue; carocoids connected by a cartilage on each side. Xenopidæ. Pipidæ.

2. Arcifera. Internal nostrils separate; a tongue; coracoids connected by a separate cartilage on each side, one overlapping the other. T'en families: Bufonidæ.

3. Suborder: Firmisternia. Internal nostrils separate ; a tongue ; a single median cartilage connecting all the coracoids; scapular arch free. Eight families. Ranidæ.

4. Suborder: Gastrechmia. As in the preceding, but scapular arch articulated to skull. Hemisidæ.

IV CLASS: Moncondylia. Basicranial axis ossified; vertebral column chiefly of centra; an amnion and alantois. Limbs as in Bratrachia ; one occipital condyle: a suspensorium of the lower jaw ; mandible segmented ; ankles between first and second rows of carpal and tarsal bones; heart with three or four chambers.

I. Subclass: Reptilia. Anterior limbs ambulatory, with numerous carpal and metacarpal bones; two aorta roots; integument consisting partly of scales; In eight 
out of the nine orders the quadrate bone is united with the postorbital bars by a suture; in the ninth it is loosely articulated with the postorbital bars and only proximally.

I. Order: Ichthyopterygia, extinct.

2. Order: Testudinata. No supratemporal; sub- and post-pelvic ossifications; interclavic and clavicles separated from and below scapular arch; ribs oneheaded; caracoid large, free. A paroccipital bone. Suborders: Athece, leather back turtles. Trionychoidea, soft or mud Tortoises. Cryptodira, Turtles. Land Tortoises. Pleurodira, southern fresh water Tortoises.

3, 4, 5, and 6. Orders: (Theromora, Plesiosauria, Ornithosauria, Dinosauria) extinct.

7. Order: Crocodilia. Cranium with two postorbital bars; no paroccipital bone. Suborders: Parasuchia and Pseudosuchia extinct. Eusuchia. Nareal canal underroofed to behind larynx; no clavicle; pubis excluded from acetabulum; external nostrils anterior. True crocodiles.

8. Order: Rhynchocephalia. Cranium with two postorbital bars; no paroccipital bone. Ribs one-headed; an interclavicle; acetabulum closed; feet ambulatory. Suborders: Sphenodontina. One species of Sphenodontidæ living in New Zealand. Choristodera. Extinct.

9. Order: Squamata. Quadrate bone in contact only with adjacent elements; no paroccipital; supratemporal present; ribs one-headed; one or no postorbital bar. Suborders: Lacertilia (Lizards). Very numerous, eleven superfamilies with twenty-five families. Pythonomorpha, extinct. Ophidia (Snakes) with six superfamilies and nineteen families.

2. Subclass: Aves. Anterior limbs volant, with the carpels and metacarpels more or less coössified and re- 
duced in numbers; integument consisting partly of feathers; one aorta root.

I. Superorder: Saunurce. Metacarpal and carpal bones all distinct, the digits with ungues; caudal vertebræ numerous unmodified; clavicles united; pelvic elements distinct: teeth present. Ornithopappi with Archæopteryx, extinct.

2. Superorder: Eurhipidure. Metacarpal and carpal bones reduced in number, coössified; ungues wanting or single; caudal vertebræ reduced in number, the terminal areas usually coössified.

r. Tribe: Ratite. Ischium usually free from ilium posteriorly; palate dromæognathous (i. e., maxillopalatines articulating with vomer, which is between them, palatines not articulating directly with sphenoid rostrum); no teeth. Four orders, two of which are living. Struthiones (Ostrich). Sternum without keel; clavicles; wings rudimental. Apteryges (Kiwis). Sternum without keel; no clavicles; wings rudimental.

Second and third tribes (Odontolce, Odontotormæ) are extinct.

4. Tribe: Euomithes. Ischium coössified with ilium posteriorly, palate not dromæognathous; feathers distributed in area, those of the wings much differentiated. Fifteen suborders of birds with numerous families belong here.

5. Tribe: Impennes. Ischium coössified with ilium; no teeth; feathers universally distributed and not differentiated on wings. Only order: Ptilopter with the family Aptenodytidæ (penguins).

V CLASS: MAMMALIA. Basicranial axis ossified; vertebral column of centra; an amnion and allantois. Limbs as above; two occipital condyles; no suspensorium. 
of the lower jaw; mandible not segmented; ankles between propodial bones and carpus or tarsus; heart with four chambers; warm-blooded. Viviparous, suckling their young with the secretion of milk glands (mammaria).

I. Subclass: Prototheria. An interclavicle; a large caracoid articulating with the sternum. Two orders extinct. Only living order: Monotremata. Jaws elongated forming a beak; no true teeth at maturity; the feet are short, five toed, and furnished with strong claws; oviparous. Ornithorhynchidæ. No extinct species known.

2. Subclass: Eutheria. No interclavicle; caracoid very small, coössified with scapula; not reaching sternum.

I. Section: Didelphia. Marsupial pelvic bones; palate perforated; vagina double; placenta wanting; corpus callosum rudimental; cerebral hemispheres small.

I. Order: Marsupialia. (Kangaroos. Opossums.) One deciduous molar tooth. Pouch or marsupium encloses the mammary glands and receives the helpless young after birth.

2. Section: Monodelphia. No marsupial bones; palate generally entire; one vagina ; placenta and corpus callosum well developed. A. Mutilata. Posterior limbs wanting, or represented by minute rudiments; anterior limbs oarlike.

2. Order: Cetacea. (Whales.) Elbow joint inflexible ; carpal discoid, and, with the phalanges separated by cartilage; lower jaw without ascending names ; posterior limbs absent. Represented by three orders: Archceoceti. Odontoceti. Mysticeti.

3. Order: Sirenia. Elbow joint flexible; carpals 
and phalanges with close articulations; mandible with ascending ramus. Incisors replaced; grinders flat, no canine teeth. Sirenia.

B. Unguiculata. Posterior limbs present; unequal phalanges compressed and curved on one or all the feet. Carpal and tarsal bones generally in linear series.

4. Order: Edentata. Teeth without enamel; no incisors ; limbs ambulatory; hemispheres small. Vermilinguia (Ant-eaters), Dasyopoda (Armadillos), Bradypoda (Sloths).

5. Order: Glires. Teeth with enamel; incisors present. No postglenoid process; mandibular condyle not transverse; mastication proal; with freely movable clawed digits; hemispheres small. Suborders: Hytricomorpha (Porcupines, Cavies, etc.). Sciuromorpha (Beaver). Myomorpha (Mice, Rats, etc.). Lagomorpha (Rabbits).

6. Order: Chiroptera. Teeth as above. Anterior limbs volant; hemispheres small. Suborders: Amimalivora (insectivorous Bats). Frugivora (frugivorous Bats).

7. Order: Bunotheria. Teeth as above. A postglenoid process; mandibular condyle transverse; mastication orthal; no scapholunar bone; hemisphere usually small, smooth. Four suborders. One living. Insectivora (Hedgehogs, Shrews, Moles).

8. Order: Carnivora. Teeth as above. A postglenoid process; limbs not volant, with a scapholunar bone; mastication orthal; hemispheres larger, convoluted. With strongly clawed digits. Two suborders: Fissipedia, digits distinct; posterior limbs free. Bear. Badger. Skunk. Sea-otter. Dog. Civet. Hyena. Cat. Pinnipedia, digits united into paddles by integument; hind limbs partly enclosed in general integument. Seals. Walruses. 
9. Order: Ancylopoda, Carpal and tarsal bones alternating; faceted. Anterior limbs prehensile; mandibular condyle and mastication transverse. Extinct. C. Ungulata. Posterior limbs present; ungual phalanges not compressed and hooked.

Io. Order: Taxeopoda. Carpal and usually tarsal bones in linear series. Limbs ambulatory; teeth with enamel. Suborders: Quadrumana (lemurs). Anthropomorpha (Orang-outang. Gorilla. Man).

Ir. Order: Toxodontia. Carpal bones alternating ex ternally; tarsals in linear series; limbs ambulatory, median digits longest; teeth with enamel. Extinct.

I2. Order: Proboscidea. Tarsal bones alternating; carpels linear or reversed diplarthrous. Cuboid bone partly supporting navicular, not in contact with astragalus; no canine teeth. Long proboscis serving as prehensile organ. Elephantidæ.

I3. Order: Amblypoda. Both tarsal and carpal series more or less alternating; the distal row inwards. Os magnum not supporting scaphoides; cuboid supporting astragulus; superior molars tritubercular. Extinct.

I4. Order: Diptarthra. Tarsal and carpal series as in preceding; os magnum supporting scaphoides molars quadritubercular. The most specialized type of Mammalia in regard to structure of skeleton dentition and digestive system, but inferior to the anthropomorphous Taxeopoda in the structure of the brain. Suborders: Perissodactyla (Rhinoceros. Tapir. Horse). Artiodactyla (Swine. Boar. Hippopotanus. Dromedary. Camel. Giraffe. Musk Deer. Antelope. Gnu. Sheep. Goat. Ox; and allies).

Inasmuch as the anatomy of the Vertebrates receives special attention in all the smaller or larger text-books 
on Practical Zoölogy, and is frequently taught as a separate branch, we considered it sufficient to confine ourselves here to a few remarks on the reproduction, development and phylogeny of this branch.

Reproduction is always sexual, and separate sexes are the rule (except in Serranus scriba and partly in Bufo variabilis). The sexual organs are generally paired, opening either directly from the body cavity through genital pores to the exterior, or indirectly through paired ducts. These often unite in the lower Vertebrates, forming an unpaired canal which opens into the cloaca, or they are highly differentiated, and connected with accessory glands and copulatory organs, most complicated in the Mammalia. The large majority of Pisces, Batrachia and Monocondylia are oviparous, whilst all the Mammalia are viviparous.

The development of the embryo begins either with a total equal, or unequal or discoidal segmentation ( $p$. 43), which usually results in a disc-like embryonic formation or blastoderm lying upon the yolk. The posterior end of the disc develops into the alimentary cavity, whilst the layers of the blastoderm thicken and form a primitive streak marking the long axis of the embryo. An ectodermal groove arises along the dorsal surface, growing together along the edges and forming an epithelial free tube (medullary) which gives rise to the spinal cord and the brain, and beneath which the entodermal notochord develops. The mesoderm extends along the sides of these structures, forming two bands, the median portions of which become gradually segmented (proto vertebral plates), developing into the proto-vertebræ. Between these and the unsegmented lateral plates the archinephric duct separates off, while 
the genital glands arise from the peritoneum of the lateral mesodermal plates. In the meantime the alimentary canal has become further developed on the ventral side of the blastoderm, gradually absorbing the yolk and usually leaving a yolk sac. Metamorphosis occurs only in the naked Salientia and several Fishes. In the Monocondylia and Mammalia the outer layer of the blastoderm is raised at the anterior and posterior end of the embryo, and forms two folds covering the head and tail end. These folds gradually fuse over the body and form a closed sac filled with fluid (amnion). Another organ characteristic of the higher Vertebrates is the allantois correlated with the disappearance of branchial respiration and the complete absence of a metamorphosis. It arises at the posterior end of the body as a vesicular evagination of the ventral wall of the alimentary canal and grows into a large vascular sac filled with fluid, and representing an embryonic respiratory organ. 


\section{INDEX.}

Acantharia, 20.

Acanthocephali, 108.

Acarina, I93.

Acoela, 96.

Acotylea, 95 .

Actinaria, 85 .

Actinopterygia, 294 .

Aculeata, I88.

Adambulacral, 267.

Adductor muscle, 248 .

Agassiz, L., Io.

Agnatha, 29I.

Allantois, 302.

Alloiocœla, 96.

Alternation of generation, 70 .

Alveoli, 269.

Amblypoda, 300 .

Ambulacra, 265.

Amnion, 302.

Amœboid cells, 45 .

Amœbina, 19.

Amphineura, 222.

Amphipoda, 173.

Ampulla, 267.

Analogy, I3.

Anatinacea, 234 .

Ancyclopoda, 300.

Anisopoda, I 72.

Annulata, Io8.

Anomura, I76.

Antennæ, 196.

Antennata, 180 .

Anthozoa, 85 .
Anthropomorpha, 300 .

Anura, 293.

Aplacophora, 222.

Apoplasmatic, 45,59 .

A poscolecida, I35.

Appendiculariidæ, 280.

Apterygota, 183 .

Arachnoidea, 189 .

Araneidea, 592.

Archhydra, 88.

Archiannelida, I Io.

Archiblastula, 38 .

Architænioglossa, 225

Archoplasmic, 32 .

Aristotle, 8.

Aristotle's lantern, 269.

Arthrodira, 292.

Arthrostraca, I72.

Articulata, 257.

Ascidiæ, 278.

Ascidiaceæ, 280 .

Ascoglossa, 228.

Asconidæ, 78 .

Assimilation, 7, 62 .

Asteroidea, 262.

Astracoda, I68.

Astropectinidea, 263.

Auditory organs, 52, 53 .

Auricularia, 274.

Aves, 296.

Autoplasmatic, 45 .

Axis cylinder, 48 .

Axopodia, 23. 
Azygobranchia, 224.

Baer, C. E. v., Iо.

Balanoglossus, 275 .

Basal nembrane, 6r.

Basommatophora, 226.

Bateson, 276.

Batrachia, 294.

Bilateria, 4I.

Biogenesis, I5.

Biology, 12.

Bivium, 266.

Blastocœlum, 36 .

Blastoderm, 36 .

Blastoidea, 258.

Blastopore, 36 .

Blastosphere, 36 .

Blastozoa, I2.

Blastula, 35 .

Blood circulation, 64 .

Bojanus, organ of, 253 .

Bothriocephalus, 97 .

Brachiolaria, 273.

Brachiopoda, I I 5 .

Brachyura, I76.

Branchiata, 167 .

Branchiopoda, I68.

Branchiura, I69.

Brisingidea, 263.

Bristles, 46.

Bryozoa, II 4 .

Budding, 70 .

Bunotheria, 299

Byssus, 246.

Calcaria, 77 .

Calcispongiæ, 77 .

Campanaria, 82 .

Capitellidæ, Iro.

Cardiacea, 233.

Carnivora, 299.

Cartilage, 6r.
Caryokinesis, 32 .

Catallacta, 22.

Categories of the System, I6.

Cell, 5, 46, 48 .

Cellulose, 24 .

Cenogenetic, I5.

Centrolecithal, 40 .

Cephalochorda, 290.

Cephalopoda, 234 .

Cephalothorax, I69.

Ceraspongiæ, 78 .

Cestoda, 97.

Cetacea, 298.

Chætognatha, I 6 .

Chætopoda, Io9.

Cheliceræ, 216.

Chilipoda, I8r.

Chimæroidei, 292.

Chiroptera, 299.

Choanoflagellata, 2 I.

Chondrastei, 293.

Chordata, 278.

Chorion, 3 I.

Chromosome, 33 .

Chromatophere, 24I.

Chun, 93.

Cidaridea, 259.

Cilia, 45 .

Cirripedia, I69.

Cladocera, I68.

Claus, 204.

Clavulæ, 267 .

Clypeastridea, 259.

Cnidaria, 49, 8I.

Cœlenterata, 76 .

Cœloblastula, 38 .

Cœlum, 42.

Cœloplana, ıо3.

Coleoptera, I87.

Collembola, I83. 
Connective tissue, $6 \mathrm{I}$.

Cope, 12, 290.

Copepoda, 168.

Copulation, 67 .

Corals, 85 .

Cormus, 29.

Corpus vitreum, 56.

Corrodentia, 184 .

Cotylea, 95 .

Craniata, 29 .

Crevettina, 173 .

Cribrellum, 2 I 7.

Crinoidea, 256.

Crossopterygia, 293.

Crustacea, 167.

Crocodilia, 296.

Crystaline style, 247.

Ctenidium, 237.

Ctenophora, 87 .

Cubomedusæ, 86.

Cumacea, I74.

Cuticula, 6r.

Cuvier, 9 .

Cyclomyaria, 283.

Cyphophthalmidea, I9I.

Cystidea, 258.

Darwin, Charles, II, 15, 7I.

Decapoda, I75.

Delamination, 40.

Dentomerit, 24 .

Dermaptera, $\mathrm{I} \delta_{3}$.

Desor, I24.

Dibranchiata, 235 .

Dicyemida, 76.

Didelphia, 298.

Differentiation, 7 I.

Dimyaria, 248.

Dinoflagellata, 2 I.

Dinophilus, II6.

Diotocardia, 223.
Diplopoda, I82.

Dipneumona, 264.

Dipuoi, 292.

Diptera, I89.

Discoidal, 38 .

Discomedusæ, 87 .

Disconauthæ, 84 .

Docoglossa, 224 .

Dysasteridæ, 260.

Ecardines, I 6 6.

Echinodermata, 256.

Echinasteridea, 262.

Echinometridæ, 259.

Echinoidea, 258.

Echiuridæ, III.

Ectoderm, 66.

Ectoparasitica, 96.

Ectoprocta, II4.

Edentata, 299.

Ederioasterida, 258.

Elasmobranchii, 292.

Embryology, I3.

Embryonic division, 69 .

Enteropneusta, 275.

Eutoderm, 66.

Entomostraca, 167.

Eutoparasitica, 97.

Eutopodite, 195.

Entoprocta, II4.

Entostyle, 286.

Ephemeridea, 184 .

Epimerit, 24.

Epitheliogenous, 44 .

Epithelium, 44, 50, 5 I.

Epitheloids, 44.

Errantia, III.

Eucharis, 93.

Eucopepoda, 168.

Eudarina, 27.

Eulamellibranchia, 232. 
Euornithes, 297.

Eurhipiduræ, 297.

Euryalidea, 26I.

Eutheria, 298.

Euthyneurous, 250 .

Excretion, 7, 63 .

Exopodite, 195 .

Eye, 55-59.

Fat globules, 59 .

Fertilization, theory of, 73 .

Filibranchia, 23I.

Fission, 68.

Flagellata, 2 I.

Flagellum, 45 .

Function, 52 .

Furrow, 36.

Galeritidæ, 260.

Gametæ, 27.

Ganglion, 47 .

Gastraæ, I5, 35 .

Gastræada, 76.

Gastrocœlom, 37 .

Gastropoda, 223.

Gastrotricha, I I7.

Gastrula, 30, 35, 39 .

Germinal layer, 37 .

Germ plasm, 72.

Gigantostraca, 178 .

Gill, 63 .

Glands, 60 .

Glires, 299.

Globigerina, 20.

Gnathobdellidæ, Io9.

Gonochorism, 30.

Goriidæ, I07.

Gregarinida, 2 I.

Growth, 7 .

Hæcke1, 6, 7, 12, I5.

Halichondrinæ, 8I.

Hatschek, 12, 16, 43, 73 .
Heider, 275.

Heliozoa, 20.

Helminthophya, 275 .

Hemiaspidæ, I78.

Hemichorda, 275.

Hemimyaria, 283 .

Heredity, $7 \mathrm{I}$.

Hermaphroditism, 30,67 .

Heteraxonia, 4I.

Heterogeny, 70 .

Heteromyaria, 248.

Heteroptera, I 86.

Heteratricha, 22.

Hexactinellidæ, 77 .

Hexapoda, I82.

Hilaire, Geoffrey St., ro.

Hinge, 243.

Hirudinei, Io8.

Histology, 44.

Holocephali, 292.

Holothuroidea, 263.

Holotricha, 22.

Homolynamous, I4.

Homology, I3.

Homophyly, I3.

Homoptera, I86.

Homotypical, I4.

Hoplonemertini, I05.

Hydrocoralliæ, 8I.

Hydridæ, 8I.

Hydromedusæ, 8r.

Hydropolyp, 88.

Hydrozoa, 8I.

Hymenoptera, I88.

Hyperina, 173.

Hyperoarti, 29I.

Hyperotreti, 29I. ,

Hypotricha, 22.

Ichthyopterygia, 296.

Ichthyotomi, 292. 
Impenues, 297.

Imperforata, I 9 .

Individual, 5 .

Infusoria, 22.

Insecta, I82.

Interambulacral, 267 .

Intracellular, 60.

Invasion, polar, 38 .

Irritability, 6 .

Iris, 55 .

Isopoda, 172.

Isospore, 26.

Kidneys, 64 .

Köhler, 276.

Korschelt, 275.

Kowalewsky, I 2, 277.

Læmodipoda, I 73.

Lamellibranchia, 230.

Lamprey, 29I.

Lang, I 2.

Larvacea, 278.

Lemnisci, 129.

Lens, 56.

Lepadidæ, 169.

Leptocardii, $29 \mathrm{I}$.

Leptostraca, I $7 \mathrm{I}$.

Leuconidæ, 78 .

Leukart, 76 .

Linguatulida, I93.

Linnæus, 8.

Locomotion, 65 .

Lung, 63 .

Lysopteri, 293.

Macrospore, 26.

Macrura, I 76 .

Madreporaria, 85 .

Madreporic plate, 268.

Malacobdellini, I05.

Malacostraca, I70.

Mammalia, 297.
Mandibles, 196.

Marsipobranchii, 29 I.

Marsupialia, 298.

Maxillæ, I96.

Maxillipeds, I96.

Medulla, 50 .

Membrane, 24, 6r.

Meroblastic, 38 .

Mesenchyma, 42.

Mesoderm, 37, 40, 66.

Metabolism, 6 .

Metakinesis, 33 .

Metameres, 137.

Metamorphosis, 67, 213, 214.

Metapodium, 245.

Metazoa, 7, 29.

Metschnikoff, 76, 93.

Microspore, 26.

Mollusca, $22 \mathrm{I}$.

Monera, 6, I9.

Monocondylia, 295.

Monodelphia, 298.

Monomyaria, 246.

Monotocardia, 224.

Monotremata, 298.

Monozoa, 97.

Morphology, 12.

Motion, 6.

Müller, Joh., 278.

Muscular fibrils, 46, 47.

Musivian eye, 57 .

Myacea, 233.

Myoblast, 46.

Myophrysks, 24.

Myriopoda, I8I.

Myxopodia, 23.

Myzostomida, I I 2.

Nägeli, 7r.

Narcomedusæ, 83 .

Nasellaria, 20. 
Nauplius, I95.

Nematocyst, 60.

Nemathelmia, ro5.

Nematodes, I06.

Nemertini, I04.

Nephridium, 63 .

Nerve epithelia, 50 .

Nerve fibril, 47,48 .

Nervous system, central, 49 .

Neuroptera, I86.

Notochord, 289.

Non-Calcarea, 77 .

Nucleus, 5 .

Nuda, 87 .

Nudibranchia, 229.

Octopoda, 235 .

Odonata, I84.

Oligochæta, Iog.

Ontogeny, I5.

Opheliacea, I Io.

Ophiuridea, 26r.

Ophiuroidea, 260.

Opisthobranchiata, 226.

Orthonectidæ, 77 .

Osculosa, 20.

Osphradium, 237.

Ossicula, 266.

Ostracophori, 29 I.

Ovum, 30.

Pædogenesis, 68.

Palingenetic, I5.

Pallium, 236.

Panorpata, $\mathrm{I} 86$.

Pantopoda, I79.

Paranucleus, 25.

Parapodium, 245.

Parthenogenesis, 68.

Pauropoda, I82.

Pedicellariæ, 262.

Pedipalpi, rوı.
Pellucida, $5^{8}$.

Perforat 20.

Peripatus, r8o.

Periproct, I42.

Peritricha, 22.

Peromedusæ, 86.

Person, 29.

Peticulidæ, I86.

Phalangidea, I9I.

Phœodaria, 2 r.

Pholodacea, 233.

Phoronidea, II3.

Phyllopoda, I68.

Phylogeny, I4.

Physemaria, 76.

Physiology, I2.

Phytophthires, I85.

Pigment, 59.

Pilidium, I23.

Pisces, $29 \mathrm{r}$.

Placophora, 222.

Plathelminthes, 95 .

Plecoptera, I84.

Plumularia, 82 .

Pluteus, 273.

Podopterygia, 293.

Polar body, 33 .

Pole, 35 .

Polian vesicles, 268 .

Polychæta, I Io.

Polycystidea, 22.

Polymorphism, 29.

Polyzoa, 97.

Porifera, 77.

Porulosa, 20.

Priapulidæ, II3.

Proboscidea, 300.

Propodium, 245.

Prosobranchia, 223.

Prosoma, I35. 
Prosopygii, II 2.

Prostate gland, Ior.

Prostomium, I42.

Protaxonia, 4I.

Proteida, 294.

Protobranchia, 231.

Protomerit, 24.

Protoplasm, 5 .

Protopodite, 195.

Prototheria, 298.

Protozoan, 7, I9.

Protracheata, I8o.

Protrochozoon, I20.

Protrochula, I03.

Pseudosauria, 295.

Pseudoscorpionidæ, 190.

Pseudolamellibranchia, 23 I.

Pterobranchia, II4.

Ptery gota, 183 .

Pulmonata, 225.

Quadrumana, 300.

Race, I 7.

Radiolaria, 20.

Radula, 247.

Ratitæ, 297.

Ray, 8.

Regeneration, 69.

Reproduction, 7, 66.

Reptilia, 295.

Retina, 55 .

Retinulæ, 57 .

Rhabdocœlidæ, 95 .

Rhipidopterygia, 293.

Rhizocephala, I 70.

Rhizopoda, I9.

Rhynchobdellidæ, Io9.

Rhynchocephalia, 296.

Rhynchota, I85:

Rotatoria, II6.

Rotulæ, 269.
Ryder, I8I, 182.

Salientia, 295.

Sarcolemma, 47.

Sarcodina, I9

Saururæ, 297.

Scaphopoda, 230.

Schizonemertini, I05.

Schizopoda, I75.

Schwann's sheath, 48 .

Sclera, 55 .

Scolecida, I03.

Scorpionidæ, I9o.

Scyphomedusæ, 85 .

Scyphozoa, 84.

Secretion, 60.

Sedentaria, I Io.

Segmentation. 34, 38, 40.

Selachii, 292.

Selenka, 273.

Sense, orgaus of, 5I, 53 .

Septibranchia, 234 .

Seroso, 219.

Sertulariæ, 82.

Shell, 24 .

Siphonanthæ, 83.

Siphonateræ, I87.

Siphonophoræ, 83 .

Sipunculacea, II3.

Sirenia, 298.

Sirenoidea, 292.

Solpugidæ, 190.

Somatic layer, 43.

Spatangidea, 260.

Species, 17.

Spermatoblast, 32 .

Spermatocytæ, 32.

Spermatogony, 32.

Spermatozoa, 30, 32.

Sphæridia, 267.

Spiculispongiæ, 77 . 
Spindles, 33 .

Splanchnic layer, 43 .

Spumellaria, 20.

Squamata, 296.

Stauromedusæ, 86.

Stegocephali, 294.

Stenoglossa, 225.

Sterroblastula, 38 .

Sterrogastrula, 38 .

Stigmata, 25.

Stolo prolifer, 288.

Stomatopoda, I74.

Streak, mesodermal, 42.

Streptoneurous, 250.

Strongylidæ, I07.

Stylommatophora, 226 . .

Submytilacea, 232.

Subspecies, I7.

Suctoria, 22.

Swarmspores, 26.

Syconidæ, 77.

Symphyla, I8I.

Systema Naturæ, 9.

Tænia, 97.

Tænioglossa, 225.

Taxeopoda, 300 .

Tectibranchiata, 227.

Teleostomi, 993.

Tellinacea, 233.

Telolecithal, 40.

Tentaculata, 87 .

Terabrautia, 188.

Tesselata, 257.

Testicardines, I I5.

Testudinata, 296.

Tetrabranchiata, 234 .

Tetrapneumona, 264 .

Thaliacea, 282.
Thoracostraca, I74.

Thysanoptera, I85.

Thysanura, 183 .

Tornaria, 278.

Toxodontia, 300 .

Trachea, 206.

Tracheata, I8o.

Trachomedusæ, 83 .

Trachystomata, 295 .

Trematoda, 96.

Trichina, Io7.

Trichocystes, 25 .

Trichoplax, 77.

Trichoptera, I86.

Tricladidea, 95.

Trilobita, I77.

Trivium, 266.

Trochophora, II8.

Trochosphæra, I 20.

Tubularia, 8I.

Tunicata, 278.

Urodela, 294.

Vacuoles, 25, 59 .

Variety, I7.

Vascular system, 270.

Vermes, I04.

Vertebrata, 290.

Volvox, 27.

Weissmanu, $7 \mathrm{r}$.

Whitman, C. O., 76 .

Wolf, F. C., 7 I.

Xiphosura, I78.

Zelinka, I3o.

Zeugobranchia, 223 .

Zoëa, 204.

Zonula Zinnii, 56.

Zoölogy, 5 .

Zygoneura, IO3. 






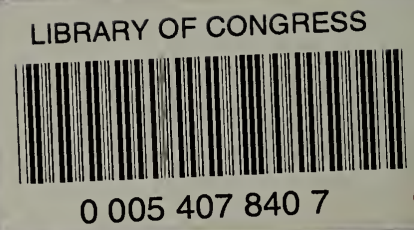

